\title{
ALEXANDRE KISHIMOTO
}

\section{A experiência do cinema japonês no bairro da Liberdade}

Dissertação apresentada ao Programa de PósGraduação em Antropologia Social da Faculdade de Filosofia, Letras e Ciências Humanas da Universidade de São Paulo, para obtenção do título de mestre em Antropologia Social.

Orientadora: Profa. Dra. Rose Satiko Gitirana Hikiji

São Paulo

2009 
Aos meus avós, Koichi, Haguino, Massao e Fumiko, aos meus pais, Isaac e Setuco, e à minha companheira, Maria Cristina. 


\section{Resumo}

Nesta etnografia, o cinema japonês exibido na cidade de São Paulo entre as décadas de 1950 a 1980 é abordado a partir da memória de antigos freqüentadores das salas de cinema do bairro da Liberdade. O foco desta investigação são os significados locais atribuídos pelos públicos nikkei e não-nikkei aos filmes japoneses, às salas de cinema da Liberdade e à experiência de freqüentá-las. A experiência vivida é acionada pelo método da história de vida e ganha centralidade na análise por meio das reflexões suscitadas pela antropologia da experiência.

Palavras-chave: salas de cinema, cinema japonês, imigração japonesa, antropologia da experiência, espectatorialidade, memória. 


\begin{abstract}
In this ethnography, the Japanese cinema which was shown in the city of São Paulo between 1950 and 1980 is evoked in the memories of old-time movie goers of the Liberdade district. This investigation focuses on the local meanings attributed by both nikkei and non-nikkei audiences to Japanese films, to Liberdade's cinemas and to the experience of frequenting them. Lived experience, which is made accessible by the method of life history, becomes central to analysis in a reflexive process provoked by the anthropology of experience.
\end{abstract}

Key-words: cinema theaters, Japanese cinema, Japanese immigration, anthropology of experience, spectatorship, memory. 


\section{Agradecimentos}

Agradeço, em primeiro lugar, a Rose Satiko Gitirana Hikiji pela maneira atenta, paciente e generosa com que orientou os passos desta pesquisa. A confiança depositada no pesquisador, o apoio irrestrito e o respeito intelectual foram fundamentais para o desenvolvimento do trabalho.

À Pró-Reitoria de Cultura e Extensão, na gestão do professor Sedi Hirano, pela bolsatrabalho concedida para o desenvolvimento do projeto $O$ Cinema no Centenário da Imigração Japonesa. A CAPES (Coordenação de Aperfeiçoamento de Pessoal de Nível Superior) pela concessão da bolsa de mestrado, de vital importância para as etapas de sistematização e redação da dissertação.

Aos funcionários do Programa de Pós-Graduação em Antropologia Social, especialmente a Ivanete Ramos, Rose de Oliveira e Soraya Gebara, pelo suporte nas questões acadêmicas. Aos funcionários do Laboratório de Imagem e Som da USP, um agradecimento especial a Paula Morgado Dias Lopes, pelo apoio e estímulo ao desenvolvimento da pesquisa. Agradeço também ao professor Koichi Mori, a Mariana Vanzolini e ao André Kees Schouten.

Aos professores da comissão de organização do Seminário Internacional Migrações e Identidades, pela oportunidade de apresentar minha pesquisa no evento e pelo convívio; especialmente, ao Sedi Hirano, pela confiança depositada num pesquisador iniciante; a Roseli Fischmann pelo estímulo e valorização da pesquisa, e ao Frederico Croci, pela postura e companheirismo.

Aos freqüentadores dos cinemas da Liberdade que generosamente concederam depoimentos para esta pesquisa, sem os quais ela não existiria: Sedi Hirano, Eunice Yokota, Alfredo Sternheim, Marina Narahara, Olga Futemma, Clara e Teresinha Nakayama, Sussumu e Zelinda Tanaka, Jo Takahashi, Carlos Reichenbach, Ricardo Mário Gonçalves, João Batista de Andrade, Cláudio Willer e Jean Claude Bernardet. Agradeço também ao Marcos Persici, a Emi Kato e a Mieko Yano Freitas, do Museu Histórico da Imigração Japonesa no Brasil, pelo apoio à pesquisa nos arquivos do museu; ao Shuhei Hosokawa pelas imagens cedidas e pela interlocução; ao Jeffrey Lesser, pela interlocução e pelo estímulo; a Setuco Kishimoto pelas preciosas traduções; ao Marco Meirelles e a Cláudia Lima, pelo apoio no registro audiovisual; a Juliana Cristina Biazetti, pelo apoio nas transcrições, ao Hélio Ishii, pelas parcerias passadas e futuras; ao Décio Yokota, pelo contato com uma das entrevistadas.

Aos professores do Programa de Pós-Graduação em Antropologia Social: Ana Lúcia Pastore Schritzmeyer pelos comentários à pesquisa feitos no curso Seminários de Projeto; 
Heitor Frúgoli Jr. pelas indicações bibliográficas, reflexões e estímulo no curso Seminários Temáticos em Antropologia Urbana; Sylvia Caiuby Novaes e Heloísa Buarque de Almeida pelas críticas, sugestões e pela compreensão com o estágio inicial da pesquisa no exame de qualificação; ao John Cowart Dawsey pelos ensinamentos contínuos desde o início de minha graduação. Agradeço também a professora Ecléa Bosi, do Instituto de Psicologia, pelo curso A memória das testemunhas e pela generosidade e respeito com que me recebeu.

Aos colegas do GRAVI (Grupo de Antropologia Social), coordenado por Sylvia Caiuby Novaes, especialmente, Miriam Lifchitz Moreira Leite, pela interlocução; Priscilla Barrak Ermel, Caio Pompéia, Fatima Toledo, Lílian Sagio Cezar, Maíra Santi Bühler, Edgar Teodoro da Cunha e Andréa Cláudia Miguel Marques Barbosa, pelo apoio, reflexões e trocas.

Aos colegas pesquisadores e amigos, pelo companheirismo, interlocução e alto astral: Ana Lúcia Marques Camargo Ferraz, Carolina de Camargo Abreu, Giovanni Cirino, Uirá Felippe Garcia, Ana Letícia Silva, Enrico Spaggiari, Paulo Ramos, Magda Ribeiro, Ana Martha Tie Yano, Camila Gauditano, Florbela Almeida Ribeiro, Rubens Alves da Silva, Vanilza Jacundino, Arieh Wagner, Marco Antônio Teixeira, Lina Shimada, Patrícia Nakayama, Rogério de Campos, Nelson Brolese, Antônio Reis Jr., Noel dos Santos Carvalho, Walter Hatakeyama, Paulo Pastorello, Alexandre da Cunha Barros, Dora Nascimento, Antônio Rodrigues do Nascimento, Igor Alexandre Badolato Scaramuzzi, Lílian Abram dos Santos, Adriano Vieira Cazalla e Antônio Redinha (in memorian). Um agradecimento especial a Adriana de Oliveira Silva, leitora atenta do trabalho e parceira de pesquisa.

À minha família: meus pais Isaac e Setuco; meus irmãos, Cristina e Eduardo; meus cunhados Fernando e a Rosana; e ao meu sobrinho Rafael. Por todo o apoio material e espiritual, pela paciência, compreensão e carinho. Agradeço também a minha outra família: a Ruth e Lia pela generosidade e carinho e ao Delmanto, pela imensa simpatia e pela evocação de uma cidade mais gentil.

Agradeço, enfim, a minha família espiritual: Luís Roberto de Paula, Juliana Rosalen, Janaína Rosalen de Paula, Marcos Pereira Rufino, Erika Andrea Butikofer e Marco Meirelles, pela irmandade e pelo apoio decisivo em todos os momentos e em todos os sentidos. Um agradecimento especial a Bimba, minha companheira querida, que me fortalece e me inspira. Jah love protect us! 


\section{SUMÁRIO}

APRESENTAÇÃ 0 ......................................................................................................... 8

1. AS SALAS DE CINEMA DA LIBERDADE .......................................................... 16

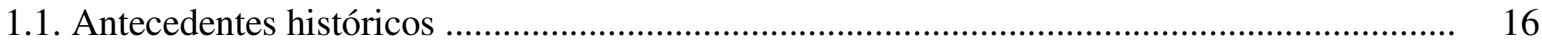

1.2. As salas de cinema 'fixas' do bairro da Liberdade ...............................................................

1.2.1. Cine Niterói: a retomada do bairro japonês .................................................................... 20

1.2.2. Cine Tokyo e depois... Cine Nikkatsu: a onda jovem ....................................................... 24

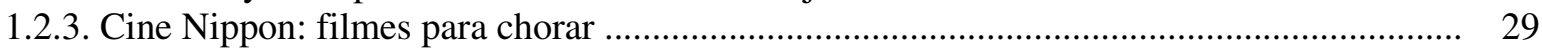

1.2.4. Cine Jóia: riqueza na tela e decadência na sala ............................................................... 31

1.3. Nodo-jiman, shows com atores-cantores e rádios nikkeis .................................................. 34

1.4. Paquera nas filas dos cinemas, bailes nikkeis e piqueniques .............................................. 36

1.5. As salas da Liberdade e o circuito de projeções ambulantes ................................................. 37

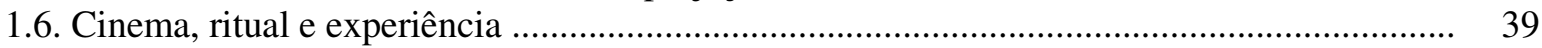

2. OS FILMES JAPONESES EM SÃO PAULO ..................................................... 53

2.1. São Paulo, Estados Unidos e Japão: montagem paralela ...................................................... 53

2.2. Séries de filmes e versões de uma mesma história .............................................................. 58

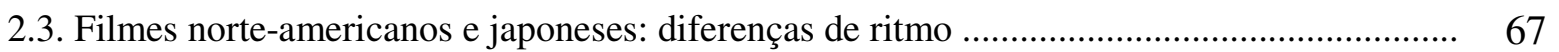

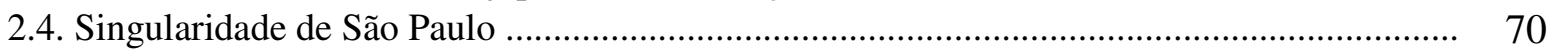

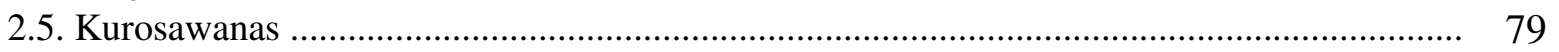

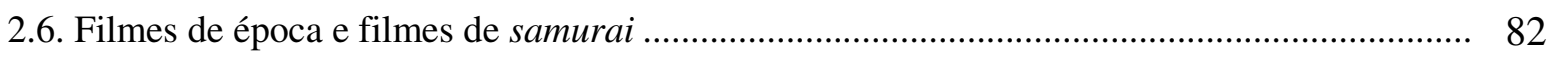

2.7. Crítica da tradição e subversão do status quo .................................................................... 92

3. O PÚBLICO PAULISTA ............................................................................. 111

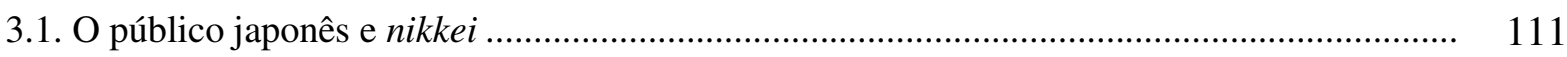

3.1.1. A dimensão trágica da Segunda Guerra Mundial [ruptura] ............................................... 111

3.1.2. Pós-guerra: a cisão entre kachigumi e makegumi [crise e sua intensificação] ..................... 119

3.1.3. Sessões lacrimais: o cinema como catarse [ação reparadora] …….................................... 123

3.1.4. Hipótese: o cinema como meio de reconciliação [desfecho] ……...................................... 126

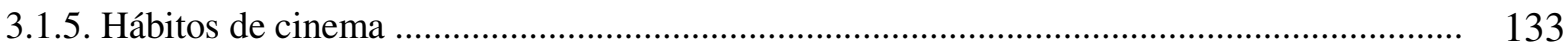

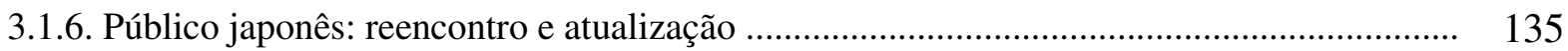

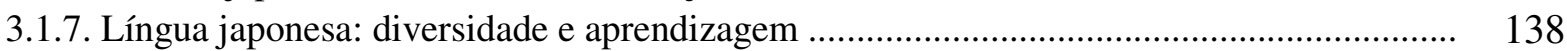

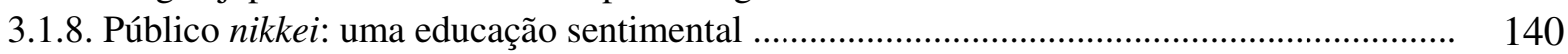

3.2. O público não-nikkei: penetras numa festa de familia ......................................................... 144

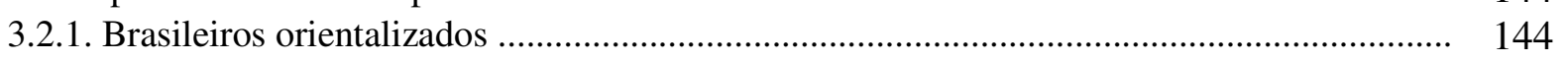

3.2.2. A crítica de cinema paulista: difusão do cinema japonês e divisão ideológica ................... 147

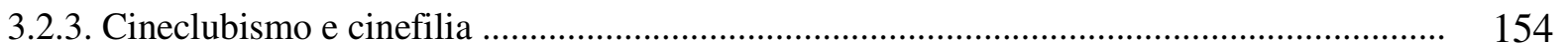

3.2.4. Influências do cinema japonês no cinema paulista .......................................................... 158

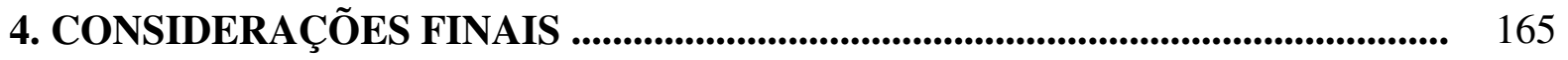

5. REFERÊNCIAS BIBLIOGRÁFICAS .................................................................... 171 


\section{Apresentação}

Em maio de 2006, fui pela primeira vez às sessões de cinema japonês promovidas pelo Bunkyo (Sociedade Brasileira de Cultura Japonesa), no auditório de sua sede localizada no bairro paulistano da Liberdade. As sessões semanais são realizadas às 13 horas, contemplando principalmente os associados idosos da instituição. O filme exibido naquela tarde foi Shinsengumi Shimatsuki, de Kenji Misumi (1963). Cerca de 400 pessoas tomavam a maioria dos assentos da platéia. Apesar de meus 33 anos de idade, na ocasião, eu era o único "jovem" presente, uma vez que o público era formado por japoneses e nikkeis com mais de 60 anos.

Havia um fato ao qual eu não tinha prestado atenção: o filme seria exibido na língua original, sem legendas em português. Isso ficou evidente no momento em que o organizador das sessões apresentou o filme, expressando-se apenas em japonês. $\mathrm{O}$ que foi dito sobre o filme? Será que ele falou alguma coisa importante para a sua compreensão? - é o que eu tinha vontade de perguntar ao espectador ao lado, quando as luzes se apagaram e começou a projeção: tratava-se um filme de samurai em que quase não havia duelos, as cenas remetiam a uma intriga palaciana. O problema é que eu não compreendo e nem falo japonês. Pela primeira vez em minha carreira de cinéfilo a questão da língua se constituiu uma barreira.

Lembrei de uma conversa com o cineasta Carlos Reichenbach, na qual ele me relatou que aprendeu a assistir aos filmes japoneses sem legendas, prática que ele reproduziu com seus alunos no tempo em que foi professor do curso de cinema da Universidade de São Paulo. Incapaz de acompanhar a história, eu tentei me focalizar em outros aspectos do filme: a composição dos planos, a relação entre os atores e a câmera e a montagem. Tentava fazer o mesmo que Donald Richie, numa situação semelhante:

[...] nessa observação obtusa de uma imagem opaca após a outra, estava sendo ajudado por minha ignorância. Como os diálogos e a história não me distraíam, eu podia prestar atenção nas intenções do diretor, perceber suas propostas e observar como conseguiam os efeitos (Richie, 1996: 64).

Richie era um norte-americano recém-chegado ao Japão na época desse episódio. No meu caso, eu era um brasileiro, residente na cidade de São Paulo, que assistiu a um filme japonês sem nada entender. Um brasileiro, porém, de ascendência japonesa: a experiência vivida nessa sessão foi incômoda; não consegui, como Reichenbach e Richie, concentrar-me nos outros elementos fílmicos além da história, fiquei apenas lamentando as diversas oportunidades de aprender japonês, propiciadas pelos meus pais e nunca levadas a sério. 
Talvez porque, na época, tendo sido criado fora da "colônia japonesa", o japonês não me fazia falta. Naquela tarde no Bunkyo, no entanto, esse conhecimento fez uma falta brutal.

$$
* * *
$$

No início de 2008, ano em que se comemorou o centenário da imigração japonesa no Brasil, compareci a algumas sessões da mostra Cinema japonês - 100 anos de Japão no Brasil, realizada no Centro Cultural Banco de Brasil de São Paulo ao longo de vinte dias de programação. Em cada dia, havia três sessões $(13 \mathrm{~h} 30,16 \mathrm{~h}, 19 \mathrm{~h})$, e para ter acesso a elas era necessário retirar senha no balcão de recepção, aberto uma hora antes de cada sessão.

No dia 22 de fevereiro, tentei assistir ao filme Mulher de areia (Suna no onna, 1964), que seria exibido pela segunda e última vez. Cheguei com a antecedência recomendada, porém os ingressos tinham se esgotado. Dada a procura intensa pelas senhas, criou-se uma espécie de segunda chamada: um pouco antes da sessão, formava-se uma fila ao lado da fila “oficial". Quando sobrava algum lugar, as pessoas da outra fila eram chamadas. Menos pela esperança de assistir ao filme do que pelo propósito de pesquisar, resolvi esperar.

$\mathrm{Na}$ fila principal para a sessão das $13 \mathrm{~h} 30$ era possível observar a presença de uma maioria formada por japoneses e nikkeis de meia e terceira idades, além de alguns não-nikkeis dispersos entre eles. Na fila (ou aglomeração) da segunda chamada, pessoas de várias idades, com predomínio de não-nikkeis. ${ }^{1}$ Conversei com uma senhora que disse ter assistido Mulher de areia na década de 1960, mas que não se lembrava onde. A fila "oficial" começou a andar, todos entraram, e após a constatação de que ninguém havia desistido, frustrando as expectativas do grupo da segunda chamada, a senhora reclamou: "Como é que programam uma mostra de cinema japonês num auditório tão pequeno com uma colônia japonesa tão grande na cidade!". ${ }^{2}$ Fiquei sabendo depois com a recepcionista, que os japoneses e nikkeis chegavam muito cedo e formavam fila do lado de fora do prédio desde o horário de abertura.

Em agosto de 2007, fui à Fundação Japão, onde Shuhei Hosokawa ministrou uma palestra intitulada “Cinemaya percorre o Brasil”. Professor do International Research Center

\footnotetext{
${ }^{1} \mathrm{O}$ termo nikkei, empregado nesta etnografia, designa todas as pessoas de ascendência japonesa no Brasil, distinguindo-as, portanto, da geração de imigrantes, tratados aqui como japoneses. Não-nikkei refere-se aos brasileiros sem ascendência japonesa.

${ }^{2}$ Capacidade de platéia do cinema do CCBB-SP: 70 lugares, mais três assentos para portadores de deficiência.
} 
for Japanese Studies (Kyoto), Hosokawa publicou no Japão, em 1998, o livro Cinemaya Burajiru wo iku [mesmo título da palestra]. Fiquei sabendo da existência desse livro por meio de outro pesquisador japonês, Sachio Negawa, que chegou a emprestar-me um exemplar. Apesar de abordar diretamente o tema da minha pesquisa, o cinema japonês no Brasil, por ter sido escrito em japonês, esse livro não constava na bibliografia que eu pretendia analisar. No entanto, surgiu uma oportunidade de contato com a pesquisa de Hosokawa, pois a palestra seria ministrada em japonês com tradução simultânea em português.

Logo após as apresentações iniciais, iniciou-se a atividade com a exibição de um curta-metragem da cineasta nikkei Olga Futemma, Chá verde e arroz (1988), que narra os percalços enfrentados pelos projecionistas ambulantes de cinema japonês no meio rural. $\mathrm{O}$ filme terminou, cedendo lugar a uma fotografia antiga em que se via um grupo de japoneses, um automóvel, dois projetores e um gramofone (Fig. 2). A aparição da imagem na tela desencadeou um burburinho na platéia. O professor tomou então a palavra afirmando sentir-se feliz com a presença de um dos atores do curta-metragem e de Sussumo Tanaka, irmão do fundador do Cine Niterói. Hosokawa solicitou a participação do público, querendo saber das impressões sobre o filme exibido.

Assim que abriu a palavra, um senhor de terno e gravata, sentado numa das primeiras fileiras, começou a falar em japonês, não para responder à pergunta, mas para comentar a fotografia. Do fundo do auditório, eu ouvia com dificuldade algumas palavras: "Hirata... cinema-ya..." Uma senhora sentada ao lado dele começou a falar em japonês. A tradutora interrompeu-a e passou a traduzir: "Sinto muito orgulho porque o projecionista da foto é o meu pai, que também participou dessa história”. Mas a tradutora não nomeou o Sr. Hirata.

O palestrante passou a palavra a outro, mas a senhora continuou a falar em japonês. Hosokawa passou a intercalar perguntas em português e em japonês: "Você é irmã?" "Sou irmã dele”, respondeu ela. E o professor: “Ah, hontô?” [Mesmo?] O senhor ao lado dela, que descobrimos ser seu irmão, completou: "Nós somos filhos do Sr. Hirata, da Nippon Filmes do Brasil". Risos nervosos eram ouvidos na platéia. O professor disse em português: "Um pouco complicado..." Ela tentou mais uma vez: "Nipakku Filmes...", assim como seu irmão: "Ele era proprietário do Cine Nippon".

Hosokawa passou a falar sobre a imagem: "A foto mostra a exibição de um filme, em 1936, na cidade de Bastos. Quem é quem na imagem eu não sei, este aqui é... esta aqui é uma residente..." - apontando para uma mulher, na fotografia, que segurava uma criança. Ele observou a presença dos projetores, além de uma faixa e um cartaz. Ao afirmar que três ou quatro pessoas integravam a trupe, Hosokawa demonstrou uma certa hesitação. 
- Gonin! [cinco pessoas] - exclamou Nelson Hirata.

- Gonin? - perguntou o professor.

Pedindo licença, Hirata colocou-se ao lado do palestrante, de onde passou a manipular o mouse que movimentava o cursor sobre a fotografia na tela. Enquanto isso a tradutora disse: "Ele vai explicar. Cinco pessoas..." Ouviam-se risos. Hirata passou a falar em japonês, sendo assim traduzido: "Esse aqui é o Masaichi Sato", enquanto apontava para o homem dentro do automóvel e o professor exclamava: "Ah!”, "este aqui é meu pai, que é parceiro dele. Esse outro era benshi. Geralmente a equipe se compunha de cinco pessoas carregando o automóvel”. Alguém perguntou em japonês sobre o tipo de carro, um outro arriscou: “Caminhão?". E Hirata arrematou: "Era um pé-de-bode, carregando projetores Debret". Risadas ressoaram na platéia.

Hosokawa retomou a palavra: Masaichi Sato foi um dos pioneiros da exibição de filmes japoneses no Brasil, fundando em Bauru uma empresa, a Nippaku Shinema-sha, que chegou a distribuir e exibir cerca de 50 filmes japoneses pelo interior paulista. Ele prosseguiu dizendo que, nas exibições em lugares sem energia elétrica, o motor do projetor era acionado ligando-o, através de uma correia, ao motor do 'pé-de-bode'. Nessa fala o professor conseguiu incorporar a "expressão nativa" de Hirata, arrancando risadas na platéia antes mesmo de ouvir a tradução.

Sobre a década de 1950, o professor citou o ano de 1953 como um marco: reiniciavase a imigração japonesa para o Brasil, sendo possível importar mais filmes japoneses, ao mesmo tempo em que crescia o número de espectadores economicamente aptos a assisti-los. Disse ainda que para quem estuda a história da imigração japonesa no Brasil, como ele, o período entre 1945 a 1953 é muito interessante: os japoneses que passaram por período de opressão, ficaram livres repentinamente e iniciaram uma série de atividades que antes não podiam fazer: criar revistas, promover eventos esportivos e produzir pequenos filmes. Foi nesta atmosfera que os filmes japoneses começaram a ganhar destaque na vida diária dos japoneses. Hosokawa analisou a importação de filmes japoneses ao Brasil a partir desse marco:

Fala-se de importação, mas parece que na maioria das vezes aquilo entrava ilegalmente. $O$ que descobri é que muitos filmes que foram exibidos aqui no Brasil não faziam parte dos registros oficiais de exportação do Japão. De onde teriam vindo? Talvez do Havaí, Los Angeles, Peru, de onde teriam sido importados previamente. Interpreto o ano de 1953 como o período de transição da exibição de filmes que entravam ilegalmente para a importação legal dos filmes. Antes de inaugurar o Cine Niterói, Yoshikazu Tanaka foi ao Japão negociar a importação das películas (tradução oral: Yuko Takeda P. de Arruda). 
Nelson Hirata pediu licença novamente para Hosokawa e passou a falar longamente em japonês. A tradutora, anunciando que resumiria a fala, traduziu da seguinte maneira:

Talvez possa haver certo equívoco na interpretação, com relação à época 1945-1950: houve grande opressão por parte do governo brasileiro, inclusive a fazenda Tozan e várias propriedades foram confiscadas pelo governo brasileiro. E em 1951, quando houve um reatamento das relações diplomáticas, do Brasil foram para o Japão o sr. Tanaka, o sr. Hirata e mais um, para negociar com as companhias produtoras: Daiei, Shintoho, Sochiku e Nikkatsu. Reunir em algum lugar tantos japoneses era um problema também.

Neste momento a tradutora fica na dúvida e pergunta aos irmãos Hirata que respondem: "Não podia reunir"; "Na rua não podia conversar em japonês".

Neste episódio narrado é notável a diferença de interpretações sobre o mesmo contexto histórico. Para Hosokawa, os anos do imediato pós-guerra foram vividos pelos imigrantes japoneses como um período de liberdade, após a opressão dos anos de guerra, em que eles puderam recriar seus meios de comunicação e retomar suas práticas culturais e artísticas. Os irmãos Hirata, ao contrário, caracterizam o mesmo período como em continuidade com a opressão vivida durante a guerra, em que algumas restrições impostas aos imigrantes pelo governo brasileiro eram ainda mantidas.

Em relação aos filmes japoneses no Brasil, a fala de Hosokawa, em que ele situa a fundação do Cine Niterói como divisor entre a importação ilegal e a legal dos filmes, assim como o protagonismo exclusivo atribuído a Yoshikazu Tanaka na negociação com as companhias japonesas, acionou a versão de Nelson Hirata, em que uma pequena comitiva de distribuidores brasileiros, que incluía seu pai, foi junto ao Japão negociar com os estúdios de cinema do país.

Havia, portanto, um ponto de vista local que questionou a interpretação do pesquisador japonês, expressando uma possível tensão entre a perspectiva da experiência vivida e a contida na análise, tal como foi expressa na palestra. Em entrevista realizada algumas semanas depois, Hosokawa explicou que a base de sua pesquisa foram as fontes documentais, como anúncios e críticas dos filmes publicados em jornais nipo-brasileiros, registros de importação, livros, entre outros, uma vez que quando veio ao Brasil pesquisar, os pioneiros do cinema japonês e os proprietários das salas exibidoras já haviam falecidos. Ele não teve contato com os filhos desses pioneiros, como os irmãos Hirata. Como eles, teriam os nikkeis, isto é, os descendentes dos imigrantes japoneses, outros olhares e interpretações acerca do cinema japonês exibido no Brasil? 
Do início dos anos 1950 até o final da década de 1980, um conjunto de salas de cinema localizado no bairro paulistano da Liberdade exibiu exclusivamente filmes japoneses para um público formado majoritariamente por japoneses e nikkeis residentes no estado de São Paulo, e também por estudantes, artistas e intelectuais não-nikkeis. O foco desta investigação são os significados locais atribuídos pelos públicos nikkei e não-nikkei aos filmes japoneses, às salas de cinema da Liberdade e à experiência de freqüentá-las.

Dessa forma, não se pretende aqui elaborar uma reconstituição pormenorizada da história dos filmes japoneses na cidade de São Paulo, mas uma etnografia das representações de antigos freqüentadores dos cinemas da Liberdade acerca da experiência vivida nas décadas de 1950 e 1960, suas memórias, histórias e interpretações. O passado será assim evocado, ou seja, trazido à lembrança e à imaginação por meio da memória daqueles que viveram e testemunharam a época.

Como no trabalho de Almeida (1995) sobre os hábitos e representações do público de cinema de São Paulo nos anos 1940 e 1950, as lembranças e representações dos espectadores dos cinemas da Liberdade são acionadas por meio de entrevistas. No caso das entrevistas com os freqüentadores nikkeis, procurou-se articular, às perguntas relacionadas ao tema do cinema japonês, procedimentos de história de vida, dando alguma margem ao entrevistado para compor e combinar, de acordo com a sua vontade, momentos ou episódios do seu passado (Bosi, 1993). Nestas entrevistas isso ocorreu por meio das perguntas iniciais em que se solicitava do recordador que descrevesse a trajetória familiar e pessoal.

De acordo com Bosi, explorações abertas, como as da história de vida, provocam um estilo de resposta mais adequado à auto-biografia, o estilo narrativo. Ela argumenta que, se a memória não é passividade, mas forma organizadora, "é importante respeitar os caminhos que os recordadores vão abrindo em sua evocação, porque são o mapa afetivo e intelectual da sua experiência e da experiência de seu grupo, e até mesmo da sua cidade [...]" (idem, ibidem: 283) - no caso desta pesquisa, a São Paulo e o bairro da Liberdade das décadas de 1950 e 1960.

Ao focalizar a memória como fenômeno social, a partir do conceito de memória coletiva (Halbwachs, [1950] 1990 e Bosi, 1993 e 1994), pretende-se articular as lembranças dos entrevistados com os grupos com os quais se relacionavam. Isso se constitui como um dos objetivos desta investigação, não apenas para o público nikkei: perceber, a partir de relatos pessoais, os grupos com os quais os entrevistados freqüentavam os cinemas da Liberdade: a 
família, os grupos de amigos ou vizinhos, os colegas de escola, os parceiros de trabalho ou os integrantes de um mesmo movimento artístico.

O estilo narrativo provocado pelos procedimentos de história de vida, citado por Bosi, é também comentado por Joseph (2005). Para ele, ao reconstituir o processo de inserção urbana do migrante, a história de vida demonstra como se redefinem valores e atitudes e as descontinuidades do processo de socialização:

Hoje, aquilo que pode nos interessar é essa atenção atribuída às dissociações entre espaços de inserção e espaços de residência, entre espaço vivido e espaço representado. A partir do momento em que introduzimos um postulado de narratividade na trajetória do migrante, percebemos que ela comporta redescobertas, mediações ou rupturas com a comunidade ou a sociedade de origem, que parte das redes de socialização está deslocada, em suma, que essa trajetória comporta uma série de experiências de mobilidade que a etnografia dos enclaves não permite ver (Joseph, 2005: 116).

Neste trecho, há dois sentidos de mobilidade do migrante na metrópole, um no espaço e outro no tempo. Em relação ao primeiro, Joseph fala de dissociações entre espaços de inserção e espaços de residência. Na cidade de São Paulo, comumente se associa o bairro da Liberdade como o lugar de moradia dos japoneses e nikkeis, ignorando-se o processo de dispersão vivido por eles durante a Segunda Guerra Mundial. Mesmo antes disso, bairros como Pinheiros, Vila Nova Brasilândia, Jabaquara e Itaquera já contavam com expressiva concentração de imigrantes japoneses e seus descendentes. Qual é o significado da Liberdade para os antigos freqüentadores das salas de cinema desse bairro? Lugar de residência, lazer, comércio ou turismo?

Quanto à mobilidade no tempo, a menção às redescobertas, mediações ou rupturas com a comunidade ou sociedade de origem encontra um paralelo nesta etnografia com as aproximações e distanciamentos vividos pelos entrevistados em relação ao cinema japonês: para uns, ir ao cinema era um programa familiar vivido na infância, ocorrendo depois um progressivo afastamento na adolescência, quando passam a freqüentar outros cinemas com os amigos e colegas; outros se aproximaram do cinema japonês justamente na adolescência, cultivando-o com colegas da escola ou com amigos cinéfilos.

O desconhecimento da língua japonesa por parte do pesquisador, como já citado, determinou que a quase totalidade dos entrevistados representasse apenas os público nikkei e não-nikkei. ${ }^{3}$ Dessa forma, o trabalho concentra-se na descrição e interpretação das

\footnotetext{
${ }^{3}$ Foi realizada apenas uma entrevista com um imigrante japonês, Sussumu Tanaka, o irmão do fundador do Cine Niterói e que, apesar das valiosas informações concedidas pelo entrevistado, foi seriamente comprometida pela limitação do pesquisador.
} 
experiências desses espectadores. Evocam-se algumas experiências dos imigrantes com os filmes japoneses por meio de textos escritos por eles, e pela fala dos nikkeis e dos não-nikkeis.

Resta dizer que esta etnografia não almeja dar conta de nenhuma totalidade: ao longo dos capítulos que seguirão, pretende-se apresentar uma parte da diversidade de experiências com o cinema japonês em São Paulo, e das interpretações e lembranças a elas relacionadas. Aqui estão articuladas algumas narrativas de alguns dos antigos freqüentadores daquelas salas de cinema. É provável que outros antigos freqüentadores possam apresentar outros temas, interpretações e narrativas a respeito de experiências equivalentes. 


\section{As salas de cinema japonês da Liberdade}

\subsection{Antecedentes históricos}

As primeiras exibições de filmes japoneses no Brasil ocorreram na região oeste do estado de São Paulo, dezoito anos após a chegada das primeiras famílias de imigrantes japoneses ao país a bordo do navio Kasato Maru (1908). De acordo com o pintor e pesquisador Tomoo Handa ([1970] 1987), os caminhões de cinema ambulante começam a aparecer nos núcleos rurais de colônia japonesa entre os anos 1926 e $1927^{4}$. Os filmes exibidos naquela época correspondiam à fase dos filmes silenciosos do cinema japonês: documentários, noticiários ou filmes de ficção de curta duração eram projetados pelos ambulantes nas fazendas de café, onde havia concentração de japoneses (Kobori, 1997: 142).

No Japão, o surgimento e a atuação do benshi ou katsuben (o orador das imagens que marcham), "fez do espetáculo cinematográfico alguma coisa de essencialmente diferente do que era no resto do mundo" (Gomes, [1957a] 1981: 173). O katsuben era um profissional que se instalava ao lado da tela para explicar ou comentar as imagens. Para o pesquisador japonês Shuhei Hosokawa ${ }^{5}$, eles não eram apenas leitores, como também interpretavam vários papéis, além da arte dramática do kabuki. Se o recurso ao narrador foi recorrente na história do cinema mundial de 1900 a 1910, no Japão a profissão dos katsuben se desenvolveria até o início da década de 1930, como uma modalidade de arte. Na fase silenciosa, a popularidade destes profissionais era maior que a dos próprios atores dos filmes: além de serem mais bem pagos, seus nomes apareciam com mais destaque nos cartazes, e os espectadores dirigiam-se aos cinemas mais para ouvir determinado katsuben do que para assistir ao filme.

No Brasil, as sessões de cinema ambulante ocorriam geralmente em locais sem rede de luz elétrica. Para funcionar, o motor do projetor era ligado a um gerador, que, por sua vez, era acionado pelo movimento da roda traseira do automóvel do projecionista (Handa, 1987) (Fig. 1). Somando-se projetor, gramofone e gerador, transportava-se quase uma tonelada de equipamento. Como no Japão, nos anos 1920 e 1930, as exibições de filmes japoneses no interior paulista contavam com a atuação dos katsuben, e alguns deles chegaram a gozar de prestígio no Brasil (Hosokawa, 2007). Além de artista e pesquisador, Handa foi um imigrante

\footnotetext{
${ }^{4}$ No artigo "Roho Nippaku Shinema sha", Kimiyasu Hirata afirma que a estreia do primeiro filme japonês exibido no Brasil ocorreu em 1927 na colônia Vila Nova (linha de trem Noroeste), trazido por dois monges da Nichirenshu de Kumamoto. Intitulado Nichiren Shonin (Mestre Nichiren), o filme aborda a vida do fundador dessa ordem budista (Hirata, 1986).

${ }^{5}$ Em palestra ministrada na Fundação Japão (São Paulo) em 09 de agosto de 2007, intitulada Cinemaya Percorre o Brasil. A palestra foi traduzida simultaneamente de Yuko Takeda P. de Arruda e registrada em vídeo pelo autor.
} 
japonês que trabalhou como colono numa fazenda paulista e aqui ele descreve uma sessão de cinema ambulante no meio rural:

\begin{abstract}
Durante as sessões, estendia-se um pano branco que servia como tela e, à sua frente, no chão, um outro pano, usado nas colheitas, para o público se sentar. Lá atrás, fazia-se funcionar o motor do caminhão e era em meio ao seu barulho que se faziam as projeções. A época era de cinema mudo. Havia então o orador que, usando diferentes impostações, narrava o filme. Não raro o rolo se rompia exatamente no clímax. Enquanto consertavam a fita, o público tomava uns tragos da pinga que havia trazido de casa. Se os filmes fossem curtos, havia duas sessões. Ao invés de ingressos, pagavam-se contribuições. Cinco mil réis, colocados num envelope assinado, para que o nome de cada colaborador fosse anunciado, precedido da frase: "Vamos proceder aos agradecimentos pelas contribuições recebidas". O montante arrecadado variava de um mínimo de 60 a um máximo de 75 mil réis, que os promotores diziam ser o suficiente (Handa, 1987: 488).
\end{abstract}

Este período é marcado pela atuação de dois pioneiros do cinema japonês no país: Masaichi Sato e Kimiyasu Hirata (Fig. 2). Em 1929, Sato funda na cidade de Bauru a Empresa Cinematográfica Nipo-Brasileira (Nippaku Shinema-sha), que importava longametragens do Japão e, percorrendo as linhas das estradas de ferro Noroeste, Paulista, Sorocabana e Mogiana, realizava exibições nas colônias japonesas espalhadas pelo interior do estado (Rodrigues, 1995). A respeito desta circulação de filmes pelos núcleos de colonização japonesa interligados pelas linhas ferroviárias paulistas, dizia-se na época que o filme "fazia a linha" (Gatti, 2008: 34). Projecionista ambulante que atuava em conjunto com Sato, em 1935 Hirata funda outra distribuidora de filmes japoneses, a Nippon Eiga Kogyo. "Quando a luz se projetava na tela, principalmente as crianças gritavam de alegria. Para nós, era a maior felicidade" relembra ele num texto publicado em 1986. A Nippaku Shinema-sha e a Nippon Eiga Kogyo teriam sido as distribuidoras responsáveis por grande parte dos filmes japoneses exibidos no Brasil antes da Segunda Guerra Mundial (Kobori, 1997: 143).

A conexão entre música e cinema japoneses no Brasil aparece aqui de forma inicial. Nas descrições historiográficas sobre as primeiras projeções de filmes japoneses no país é recorrente sua associação com outro tipo de acontecimento ou entretenimento dos imigrantes: as apresentações de "canto bravo", termo cuja denominação em japonês ora é apresentada como naniwabushi, ora como rôkyoku. A maneira de remunerar os executantes (contribuições voluntárias dos participantes) e a associação dessas formas de expressão artística com a vida urbana seriam os elementos de aproximação:

Um outro acontecimento que fazia agitar e reunir as pessoas era o naniwabushi, uma espécie de canção com acompanhamento de shamisen. As apresentações de naniwabushi não se resumiam aos palcos do kaikan, eram também realizadas nas casas dos imigrantes. [...] No 
caso dos naniwabushi, o pagamento do ingresso era na forma de contribuição e quem quisesse ainda oferecia uma espécie de gratificação aos intérpretes (Handa, 1987: 489).

$\mathrm{Na}$ época antes da guerra a exibição de filmes e a apresentação de rôkyoku (canto bravo) constituíam o grande entretenimento no interior, nos povoados, e se tornaram também temas de conversas entre seus habitantes, que faziam comunicação boca-a-boca. Essas exibições de filmes e de canto bravo significavam uma vida urbana, assim os jovens tinham certa admiração pelos benshi e pelos artistas de rôkyoku de modo que às vezes queriam acompanhá-los, ir atrás deles (Hosokawa, 2007).

Em meados da década de 1920, os primeiros discos musicais japoneses importados e vendidos pela Loja Nakaya, na cidade de São Paulo, constituíam-se de gravações de músicos famosos executando gêneros musicais que utilizam principalmente o shamisen (instrumento tradicional de três cordas), dentre os quais o rôkyoku. Este teria sido um dos gêneros mais populares entre os camponeses mais velhos, tanto no Japão quanto no Brasil. No final da década de 1920 começam a surgir grupos nikkeis regionais de executantes do canto bravo, que realizavam turnês artísticas (Hosokawa, 1993: 131). O fascínio exercido pelos katsuben e pelos artistas de rôkyoku nos jovens nikkeis residentes na zona rural relaciona-se, possivelmente, com as idéias de liberdade e mobilidade associadas ao modo de vida do artista mambembe, em contraste com a fixidez do colono na terra em que labuta ${ }^{6}$.

Jo Takahashi, arquiteto de formação e diretor cultural da Fundação Japão, fala sobre as primeiras projeções de filmes japoneses na cidade de São Paulo:

A primeira sessão de cinema em São Paulo aconteceu no centro, perto da praça da Sé, no prédio da Associação das Classes Laboriosas, na rua Henrique Simonsen. É interessante porque realmente dá para imaginar que existia um cinema lá, na década de 1920, quando eram exibidos filmes japoneses: alguns documentários e filmes mudos.

Em 1933 a Nippaku Shinema-sha muda seu escritório para a capital, promovendo sessões de filmes japoneses em clubes e escolas da comunidade e depois no antigo Cine Theatro São Paulo ${ }^{7}$, situado no bairro da Liberdade (Fig. 3). A eclosão da Segunda Guerra Mundial provocou uma interrupção na distribuição e exibição do cinema japonês justamente no momento em que ele estava consolidado, com companhias exibidoras específicas e

\footnotetext{
${ }^{6}$ Esta aspiração pode ser exemplificada pela expressão "fugir com o circo": como no caso de Benjamim de Oliveira, filho de escravos que em 1882 fugiu de sua cidade natal com Circo Sotero, transformando-se em um famoso ator e palhaço: "O fascínio que o circo exercia sobre as pessoas - nos seus desejos de serem artistas, de pertencerem a um grupo 'caminhante', nas suas imagens de que a vida nômade seria oposta às pressões de uma vida de trabalho e familiar - fazia com que muitas delas fugissem literalmente com o circo. Muitos que descrevem suas fugas, como Benjamim de Oliveira, passam-nos a vivência dessas situações" (Silva, 2007).

${ }^{7}$ O Cine Theatro São Paulo foi inaugurado em 1914 na praça Almeida Júnior, bairro da Liberdade. Foi demolido em 1968 para construção da Radial Leste-Oeste. É citado como um dos primeiros locais de exibição de cinema em São Paulo: "O começo da exibição cinematográfica na cidade foi marcado pela adaptação de antigos teatros de variedades. A programação incluía espetáculos intercalados com a projeção de filmes" (Simões, 1990: 26).
} 
programação constante na capital e no interior (Rodrigues, 1995). Kimiyasu Hirata afirma que nesta época não só foram proibidas as exibições, como também todas as cópias e equipamentos de projeção foram confiscados pelo governo (Hirata, 1986). Como veremos no terceiro capítulo, guerra trouxe muitas outras conseqüências para os nikkeis residentes no Brasil, que passaram a ser tratados como "súditos do Eixo".

No pós-guerra, a retomada das sessões de cinema japonês se deu, não sem percalços, em três diferentes pontos da cidade: no Teatro Fênix, na Vila Mariana, no Cine Brasil, em Pinheiros, e no antigo Cine São Francisco (Fig. 4), mantido por frades franciscanos no salão paroquial da Igreja do Largo São Francisco (Hirata, 1986, 226). ${ }^{8}$ Segundo Edna Kobori (1997), em 1946, um ano após o fim da guerra, Kimiyasu Hirata, da Nippon Eiga Kogyo, faz a primeira tentativa de reativação das exibições de filmes japoneses no país, ao preparar o lançamento do filme Vida de artista [Ruten] (1937, Buntaro Futagawa). No entanto, como veremos adiante, distúrbios envolvendo o assassinato de lideranças das colônias japonesas do estado de São Paulo inviabilizaram a empreitada. Hirata aliou-se então a Masaichi Sato, seu ex-parceiro dos tempos do cinema ambulante e depois concorrente na distribuição de filmes, e juntos criaram outra empresa distribuidora, a Nippaku Kogyo. Com a nova associação, Vida de artista estreia nos três locais citados, um ano depois, com casa lotada.

Eunice Yokota, que estudou em uma escola primária para meninas nikkeis mantida por franciscanos no bairro da Liberdade (São Francisco Xavier), fala de suas lembranças sobre o organizador das sessões no Cine São Francisco, o Frei Bonifácio, um frade alemão muito estimado pelos imigrantes japoneses e seus descendentes:

Então quando ele vinha, ele só falava em japonês com todo mundo. E aí ele era muito simpático, uma pessoa muito acessível, e os japoneses adoravam ele, todo mundo se batizava por causa dele (risos). Quer dizer, ele chegava no objetivo, né? Era uma pessoa simpaticíssima.

Com o sucesso das primeiras sessões no pós-guerra surgem outras companhias importadoras e distribuidoras de filmes (Nanbei Kogyo, Brasias, Nichiei, Cine Ásia etc.), que, além de alimentarem a programação das redes de projeções ambulantes pelo interior paulista, viabilizam a realização de sessões de filmes japoneses em salas de cinema já estabelecidas na

\footnotetext{
${ }^{8}$ A exibição do filme nesses locais reflete a concentração dos japoneses e nikkeis nessas três regiões: centro (região do mercado da rua Cantareira e do primeiro bairro japonês no entorno da rua Conde de Sarzedas), Pinheiros (incluindo talvez as famílias japonesas do Butantã, Campo Limpo, Taboão da Serra) e Vila Mariana (região dos bairros Saúde, São Judas, Conceição e Jabaquara).
} 
cidade de São Paulo: além do Cine São Francisco, na Sala Azul do Cine Odeon e no Cine Paramount ${ }^{9}$ (Kobori, 1987).

Em artigo publicado no jornal $O$ Estado de S. Paulo (8/2/1956) por ocasião da exibição do filme Os sete samurais [Shichinin no samurai] (1954, Akira Kurosawa) no Cine Ipiranga, o crítico de cinema Francisco de Almeida Salles (1988: 183) comenta: "Só em 1939 e 1940, seis películas japonesas foram lançadas em cinemas centrais de primeira linha, o Rosário e o Broadway. Tal fato só foi repetido em 1952, com a exibição de Rashomon (1950, Akira Kurosawa) no Cine Ipiranga".

O início do reconhecimento internacional do cinema japonês devido à conquista de prêmios em festivais, a reativação das projeções ambulantes no estado de São Paulo, a proliferação de empresas distribuidoras de películas do Japão e a procura pelas sessões de filmes japoneses nos cinemas da capital anunciavam um ambiente favorável ao aparecimento de uma sala de cinema com uma programação constituída apenas por filmes japoneses.

\subsection{As salas de cinema 'fixas' do bairro da Liberdade}

\subsubsection{Cine Niterói: a retomada do bairro japonês}

Inaugurado em 23 de julho de 1953 por Yoshikazu Tanaka, o Cine Niterói é considerado a primeira sala de cinema voltada exclusivamente à exibição de filmes japoneses no Brasil (Fig. 5). A partir de 1961, passa a exibir filmes da companhia cinematográfica Toei, caracterizando sua programação pelos filmes de samurai e de aventura, além de filmes com 'estrelas' da música japonesa, como Misora Hibari, e os filmes de yakuza (máfia japonesa), que fizeram sucesso de 1965 a 1975 (Futemma, 1986 e Rodrigues, 1995). O prédio em que se localizava contava ainda com um restaurante japonês, um hotel e um salão de eventos, funcionando então como um centro cultural, com exposições de pintura, ikebana, bailes de carnaval, etc. $^{10}$

O prédio Niterói foi um empreendimento familiar. Para a sua construção, a família Tanaka vendeu todos os seus negócios e propriedades: a fazenda de café, o comércio de secos e molhados e a serralheria que mantinham no norte do Paraná. A trajetória dos Tanaka até certo ponto se confunde com a de inúmeras famílias de imigrantes japoneses no Brasil: após anos de trabalho assalariado em fazendas do noroeste paulista e do norte paranaense, Yoshikazu, o mais velho dos irmãos, inicia um trabalho de compra e venda de grãos (milho e

\footnotetext{
${ }^{9}$ O Cine Odeon foi inaugurado em 1926 na rua da Consolação, no. 40 e contava com duas salas (Vermelha e Azul, além da sala Verde na década de 1930). O Cine Paramount situava-se na avenida Brigadeiro Luís Antônio, 411 e foi fundado em 1929. (Simões, 1982).

${ }^{10}$ Conforme depoimento concedido por Eunice Yokota ao autor em 10 de março de 2008.
} 
feijão) na região, abrindo um pequeno comércio de secos e molhados na cidade de Santa Maria (PR). Duas décadas depois, conseguem comprar uma fazenda de café, cuja produção, junto com o comércio de grãos, faz os irmãos prosperarem ${ }^{11}$.

Na década de 1940 Yoshikazu passa a atuar na cidade de São Paulo: por oito anos trabalhou no Mercado Municipal Central da rua Cantareira, vendendo os cereais trazidos por seus irmãos. Nos últimos anos, a família comercializava apenas feijão. Por volta de 1950 inicia-se a construção do prédio Niterói, finalizado dois ou três anos depois, tempo considerado breve para a época: "Foi rápido porque eles tinham o recurso necessário", argumenta Mariana Tanaka, sobrinha de Yoshikazu. Sussumo Tanaka, após décadas vivendo num regime de muito trabalho e pouco divertimento, quando finalmente consegue juntar os recursos necessários, abre mão do sonho do sítio próprio para investir na idéia do irmão, mudando-se para São Paulo. "Essas paredes não foram erguidas com tijolos nem concreto; foram construídas com feijão", teria afirmado um amigo da família no discurso da inauguração do prédio (Kobayashi, 2005: 15).

Em pesquisas acadêmicas e relatos de comerciantes do bairro há um consenso sobre a importância do surgimento do Cine Niterói para a formação e a consolidação do comércio japonês na região da rua Galvão Bueno e da praça da Liberdade, bem como para a caracterização da Liberdade como bairro japonês ${ }^{12}$. A partir do ano seguinte à inauguração do cinema, lojas como Chá Flora, Ikeda, Nishitani, Doceria Niterói, Bar Kimura e Restaurante Asahi, entre outras, foram inauguradas na Galvão Bueno (Negawa, 2000: 45).

Em O Herói do Japão (Kobayashi, 2005: 22), Shizue Higaki Arai, uma das mais antigas moradoras da Galvão Bueno e personagem de diversos documentários sobre o bairro, descreve a importância do Cine Niterói para a formação do restaurante de sua família: "Isso foi mais ou menos em 1953. Aí ouvimos dizer que o Cine Niterói havia comprado o terreno em frente à nossa casa e pensamos: 'puxa, vão abrir um cinema, então é bom montarmos um bar'. Aí abrimos um bar no mesmo ano". Com o intenso fluxo de japoneses e nikkeis do

\footnotetext{
${ }^{11}$ Conforme entrevista concedida por Sussumu Tanaka e Zelinda Tanaka, respectivamente irmão e sobrinha de Yoshikazu, ao autor em março de 2009.

${ }^{12}$ Em Formação e transformação do bairro oriental (2000), Sachio Negawa descreve o deslocamento do primeiro núcleo de imigrantes japoneses (localizado no entorno da rua Conde de Sarzedas) para os arredores da Rua Galvão Bueno e da Praça da Liberdade, como parte do processo de recuperação e expansão do bairro japonês no período do pós-guerra. Com a entrada do Brasil na guerra em 1942, a primeira região do país a receber ordem de evacuação foi a da rua Conde de Sarzedas e arredores. Este fato provocou uma dispersão dos nikkeis pela cidade. Negawa aponta o estabelecimento do Prédio Niterói como o primeiro dos três eventos determinantes para o desenvolvimento da Liberdade como bairro japonês (junto com a inauguração do Bunkyo em 1964 e a abertura da estação de metrô Liberdade em 1975).
} 
interior para a capital e o movimento do Cine Niterói, o bar Asahi transforma-se em restaurante e quitanda:

O pessoal que vinha para o cinema chegava com fome e entrava para comer sushi, udon. Quando terminava a sessão, também precisavam comer, porque iam embora para longe. Tinha gente que pedia para guardar lugar na fila e vinha para o restaurante.

\section{Do que se lembram os freqüentadores do Cine Niterói?}

São Paulo, 1955. Quase todos os sábados, o mesmo ritual: a família se aprontando, o táxi grande, aonde eu ia em pé sobre os meus quatro anos, o saguão do Cine Niterói na rua Galvão Bueno. E então acontecia: depositavam-me na bilheteria do cinema, junto da funcionária nissei extremamente gentil, colocavam uma caixinha amarela de caramelos nas minhas mãos, despediam-se e eu os via atravessar a cortina verde que nos separaria por duas horas. As espiadas breves que eu dava lá para dentro me falavam de um mundo escuro e altas vozes falando em japonês. De repente as cortinas se abriam e eu reencontrava a família e, estranho, todos me pareciam transformados: minha mãe saía às vezes enxugando lágrimas; meu pai pensativo; minhas irmãs comentando os atores (Futemma, 1986: 79).

Este relato foi extraído de um texto publicado na revista Filme e Cultura, em 1986, em que a cineasta e pesquisadora Olga Futemma analisa a decadência do cinema japonês na Liberdade, que, na época, contava com apenas duas salas em funcionamento, o Cine Niterói e o Cine Jóia, que encerrariam suas atividades nos anos seguintes. Em 2008, Olga me concedeu uma entrevista narrando o episódio quase com as mesmas palavras. Do fragmento exposto acima, vários elementos chamam a atenção: o fato de que ir ao cinema era um ritual, e um ritual familiar; a identidade entre a futura espectadora de cinema e a funcionária nissei $i^{13}$, um dos marcadores de diferença destas salas em relação às demais; e a aparente confirmação da dimensão ritual do cinema: após a imersão da família num ambiente apartado e escuro, povoado por vozes estranhas, todos saíam transformados. Notável também é a evocação das diferentes formas de apreensão que um filme possibilita: emocional, no caso da mãe; reflexiva, para o pai; e na chave do star system (sistema de estrelas), para as irmãs.

Cinco anos depois, a mesma menina que ficava esperando a família na bilheteria daquele cinema arrisca uma operação clandestina para assistir a um filme pela primeira vez na vida. Após um dia inteiro ensaiando "eu tenho 10 anos", diante do porteiro acaba entregando sua idade: "Eu tenho 9". Talvez surpreso com a falta de malícia da menina (a quem devia conhecer), ele a deixa entrar. Olga recorda de se perguntar na época: "que tipo de filme uma

\footnotetext{
${ }^{13} \mathrm{O}$ termo nissei aqui empregado designa a segunda geração, isto é, os filhos dos imigrantes japoneses nascidos no Brasil.
} 
pessoa de 9 anos não pode ver e outra de 10 pode? E era um filme de espadachim, muito violento e eu lembro dos braços sendo cortados". ${ }^{14}$

Outra experiência infantil relacionada ao Cine Niterói é relembrada por Jo Takahashi. Ele se lembra de ter assistido neste cinema um filme de ninja chamado Akai kage-bôshi (1962, Shigehiro Ozawa), traduzido provavelmente como Sombra vermelha. O colorido, a ação e os efeitos especiais do filme, e não sua violência, impressionaram o espectador menino. "E claro, assim como ainda hoje a molecada gosta de ninja, na época, para nós, era um fascínio muito grande aqueles efeitos, que a gente chama de tokusatsu (...) virava um assunto nosso, da molecada, de sete e oito anos".

O Niterói era um cinema de construção tradicional, era imenso, devia ter uns 1200, 1300 lugares entre platéia, balcão e uma sala de espera que dava pra ter outro cinema pequeno na sala de espera. Ele ficava naquele espaço onde hoje passa a continuação do Minhocão, que tem o viaduto Galvão Bueno. Naquele espaço era o Cine Niterói, ele foi desapropriado pra construção da Radial Leste. Era o cinema que pessoalmente eu mais gostava, como arquitetura e tudo. [...] Eu acho que a sala mais luxuosa era do Niterói, que exibia os filmes da Toei. Eu gostava muito, tinha uma construção mais clássica, parecia um pouco o Marabá, teto alto, tela enorme, eu gostava muito do Niterói. Uma sala de espera muito bonita, era na Galvão Bueno a entrada dele (Alfredo Sternheim). ${ }^{15}$

O Cine Niterói, eu acho que foi o cinema mais luxuoso. O Cine Niterói da Galvão Bueno tinha uma lotação muito grande, algo em torno de 1.500, se não me engano. Na entrada, eles davam de cortesia um refresco colorido, que parecia um ki-suco mas não era, era mais gostoso. Até agora não sei do que era feito, mas era muito gostoso e era de graça (risos). Tinha loja de discos dentro do cinema. E sempre tinha um ikebana, que era um diferencial dos cinemas japoneses (Jo Takahashi). ${ }^{16}$

Eu lembro que do lado subia a escada e tinha um restaurante que a gente freqüentava. Depois de assistir ao filme a gente ia lá, mas não todas as vezes. Eu lembro que na entrada tinha um cartaz bem grande. Colocava-se bem na frente para mostrar que filme estava passando e eu acho que a bilheteria era do lado direito. [...] A sala era bem grande, tinha em cima também. E lotava! Fazia fila, fila assim até... hoje tem aquela ponte, então ficava a ponte inteira, ficava tudo de fila para entrar no cinema, no Niterói (Marina Narahara). ${ }^{17}$

Cinema luxuoso, cartaz grande na frente anunciando o filme em exibição, refresco colorido de graça na entrada, loja de discos de música no saguão, ikebana (arranjo floral), gentis funcionários nisseis e imensas filas no quarteirão são imagens associadas ao Cine Niterói (e não aos filmes exibidos lá) recriadas por alguns de seus antigos freqüentadores.

\footnotetext{
${ }^{14}$ Depoimento de Olga Futemma concedido ao autor em 24/6/2008.

${ }^{15}$ Depoimento concedido por Alfredo Sternheim ao autor em 24 de março de 2008.

${ }^{16}$ Conforme depoimento concedido por Jo Takahashi ao autor em 19 de março e 01 de abril de 2009.

${ }^{17}$ Marina Narahara foi entrevistada pelo autor em maio 2008.
} 
O cineasta e crítico de cinema Alfredo Sternheim descreve-o como uma sala grande e luxuosa, comparável ao Marabá, uma das principais salas da Cinelândia Paulista ${ }^{18}$. Trata-se de um olhar de um especialista, que, por força de sua profissão - crítico de cinema do jornal $O$ Estado de S. Paulo de 1963 a 1967 -, freqüentava semanalmente as salas da Liberdade e os demais cinemas da cidade. Em meio à descrição do Cine Niterói, ele fala de sua demolição em outubro de 1968, e da transformação da paisagem urbana com a construção da Radial Leste-Oeste e do viaduto Osaka. Dois meses depois, o Cine Niterói transfere-se para uma sala já existente na avenida Liberdade, com 933 lugares, onde funcionará por mais 20 anos.

Passado e presente se misturam na fala de Alfredo. Autores como Maurice Halbwachs ([1950] 1990) e Ecléa Bosi (1993 e 1994) consideram que o conjunto das lembranças de uma pessoa é também uma construção social do grupo em que ela vive, em que coexistem elementos de escolha e rejeição em relação ao que será lembrado. Lembrar não seria reviver, mas refazer, reconstruir, repensar, com imagens e idéias de hoje, as experiências do passado. A lembrança seria assim uma imagem construída pelos materiais que estariam agora à nossa disposição, no conjunto de representações que povoam nossa consciência atual.

As imagens apresentadas correspondem à faixa etária, aos interesses e à atuação dos entrevistados na época em que freqüentavam estes cinemas. Algumas delas, no entanto, como aquelas narradas por Alfredo, Olga e Jo, não se dissociam da trajetória destas pessoas, de suas práticas atuais ou das mudanças que ocorreram no bairro. Assim a lembrança do refresco gratuito articula-se com a informação da capacidade de público da sala de cinema na fala de Takahashi, que atua há mais de duas décadas com produção e administração cultural. A percepção de Futemma do cinema como ritual e das diferentes reações ao filme, ainda que referida a um episódio da infância, não pode ser separada de sua experiência e reflexão com o cinema e a sua teoria. As experiências constitutivas das histórias de vida dos entrevistados, ainda que posteriores aos fatos narrados, atuam sobre estas lembranças.

\subsubsection{Cine Tokyo e depois... Cine Nikkatsu: a onda jovem}

O Cine Tokyo foi inaugurado em 1954 na rua São Joaquim, no. 129, pelo grupo ligado à empresa importadora de filmes Nanbei Kogyo (Fig. 6). Era um empreendimento constituído por vários sócios, inspirado no sucesso do prédio Niterói: o novo prédio abrigaria também um

\footnotetext{
18 "A partir do final dos anos 30, no início do crescimento do público, começa a se formar a Cinelândia paulistana, uma região em que se concentram as melhores salas da cidade e que logo ganha este apelido. Vários cinemas são inaugurados na região das avenidas Ipiranga e São João, além dos que são abertos nos bairros" (Almeida, 1995: 48).
} 
hotel, um restaurante e a sala de cinema, em cujo auditório seriam realizados bailes. Mas ao contrário do Niterói, faltaram os recursos para finalizar o prédio, e apenas a sala de cinema funcionava no início.

Em outubro de 1955 o auditório do Cine Tokyo, conhecido na época como Teatro Nanbei (Nanbei Guekijo) foi o palco da reunião de fundação da Sociedade Paulista de Cultura Japonesa (atual Sociedade Brasileira de Cultura Japonesa, o Bunkyo). Com a instalação do escritório da Toho no Brasil, em 1958, este cinema passa a exibir exclusivamente os lançamentos desta companhia cinematográfica japonesa. Ricardo Mário Gonçalves, professor titular da Universidade de São Paulo e monge budista, recorda-se da instalação do escritório da Toho no prédio do Cine Tokyo, época em que começou a atuar como tradutor de filmes japoneses da empresa:

O Cine Jóia e o Cine Tokyo funcionavam só para a Toho. Inclusive, nos primeiros tempos, a Toho funcionava no próprio prédio do Cine Tokyo. Foi ali que eu comecei a trabalhar como tradutor em 1960. Depois eles alugaram um escritório logo no comecinho da avenida da Liberdade, perto da praça João Mendes, mas no início o escritório da Toho era no próprio Cine Tokyo. ${ }^{19}$

Em 1962, o jornalista Kokuro Mizumoto, que dirigia o São Paulo Shimbun, um dos principais jornais nikkeis de São Paulo, aluga a sala do Cine Tokyo, que passa a se chamar Cine Nikkatsu, transformando-a em cinema exclusivo da companhia cinematográfica de mesmo nome (Gamo, 2006: 32). Por um período de cinco anos são lançados filmes de novos diretores, como Shohei Imamura, Ko Nakahira e Seijun Suzuki, da geração de cineastas conhecida como nouvelle vague japonesa. Atores como Yujiro Ishihara fizeram enorme sucesso nesta época. Segundo relato de José Fioroni Rodrigues, cinéfilo e pesquisador, os filmes da Nikkatsu eram os preferidos dos jovens, que lotavam o cinema aos domingos.

Despejado pelo proprietário do prédio, em 1967 o Cine Nikkatsu encerra suas atividades. Alguns meses depois a sala foi reaberta como Cine Álamo com uma programação de filmes não-japoneses, cujo fracasso levaria ao seu fechamento (Rodrigues, 1995: 169). Alfredo Sternheim e Marina Narahara não guardam lembranças desta sala de cinema, apenas dos filmes e dos atores:

E o Nikkatsu que eu achava um cinema mais feio, ele tinha o nome da própria distribuidora. Eu acho que era na rua São Joaquim. Era o mais feio dos cinemas em termos de arquitetura. E a Nikkatsu era uma produtora mais especializada em filmes de gângster (Alfredo Sternheim).

\footnotetext{
${ }^{19}$ Conforme depoimento concedido por Ricardo Mário Gonçalves ao autor em 22 de abril de 2009.
} 
Não assistia outros filmes em outros lugares, não tenho lembrança. [Você não ia à Cinelândia, à avenida São João?] São João nada. Só assistia aos filmes japoneses, só ia ao Cine Niterói e depois ao Cine Nikkatsu (que era Cine Tokyo e virou Nikkatsu), por causa desse galã, desse ator que eu sou fã até hoje, Yujiro Ishihara. Como era a sala não lembro nada. Eu lembro que quando eu fui assistir pela primeira vez o filme Orewa materusen era proibido para 14 anos, eu tinha 12, aí levei o meu irmão e passei, porque era muito fã dele. Aí não me barraram. [E era forte o filme?] Ah, porque o filme era de briga, de sangue e sempre ele é o mocinho. Era forte nesse sentido. [...] Eu não me lembro de ter passado no Nikkatsu esse filme, Kurutta Kajitsu. Porque, pelo menos todos os filmes que passavam dele eu ia ver. Teve uma vez que eu entrei meio dia e saí às seis horas da tarde, três vezes em seguida assisti a um filme dele: Yoru no Kiba. Um filme que assisti assim, fiquei lá, de tanto que eu era fã [risos] (Marina Narahara).

Dentre os filmes precursores da nouvelle vague japonesa a pesquisadora e crítica de cinema Lúcia Nagib (1993) destaca Paixão juvenil [Kurutta Kajitsu] (1956, Ko Nakahira), filme que lançou Yujiro Ishihara, ator que se tornaria um dos maiores ídolos japoneses de todos os tempos. Este filme seria o mais bem-sucedido dos taiyozoku eiga (filmes sobre a 'geração do sol'), série de filmes baseada em romances do irmão de Yujiro (Shintaro Ishihara), produzida como parte da política de renovação da mais antiga produtora do Japão, a Nikkatsu, que passava a promover jovens $\operatorname{cineastas}^{20}$. No Japão, os taiyozoku eiga se constituiriam como mais um gênero comercial explorado pelos grandes estúdios:

Duas outras séries de filmes juvenis, de estilo americano - ou, como se dizia em japonês, mukokuseki eiga [filme sem nacionalidade] tornariam Yujiro Ishihara o ator mais famoso do Japão entre 1958 e 1962: Ave migratória (Watari Dori, nove episódios) e Vagabundo (Wagaremono, cinco episódios). Nestes, a americanização significava vestir os antigos samurais com roupas ocidentais e fazê-los vagar sem destino, freqüentemente com o violão nas costas, armando briga por onde passavam. Yujiro Ishihara era também cantor de rock e com isso provocou toda uma onda de filmes protagonizados por cantores, nos quais o enredo é ilustrado pela canção título [...] Por ingênuas que fossem, essas produções deram uma injeção de energia ao cinema dos estúdios (Nagib, 1993: 27).

O cineasta Carlos Reichenbach foi um dos freqüentadores não-nikkeis mais assíduos dos cinemas do bairro da Liberdade. "Houve uma época em que eu via mais filmes japoneses do que de qualquer outra nacionalidade, ia ver todos os filmes japoneses que entravam. Era uma coisa que não tinha nem mais crivo, o crivo era ser filme japonês [risos], entendeu?". ${ }^{21}$ Perguntado sobre as diferenças entre os públicos dos cinemas da Liberdade, ele se refere aos

\footnotetext{
20 “1956 foi também o ano em que Seijun Suzuki, que se tranferira da Shochiku para a Nikkatsu em 1954, pôde dirigir seu primeiro filme. Shohei Imamura, que tal como Suzuki passara da Shochiku para a Nikkatsu em 1954 rodou em 1958 seus três primeiros filmes. Mesmo a 'clássica' Daiei, que dispunha de uma coleção invejável de filmes de Mizoguchi e Kurosawa premiados na Europa, resolve investir nos jovens, promovendo a diretor Yasuzo Masumura, recém-chegado da Itália, onde passara dois anos estudando cinema. Em 1957 Masumura dirigiu um filme no espírito da 'geração do sol', Kichizuke (Beijos), que junto com o filme de Nakahira, compôs o manifesto cinematográfico da nova juventude japonesa” (Nagib, 1993, 24).

${ }^{21}$ Depoimento concedido por Carlos Reichenbach ao autor em 08/4/2009.
} 
freqüentadores do Cine Nikkatsu como um público mais adulto, devido aos filmes de Shohei Imamura e Seijun Suzuki, cineastas da geração que mais lhe interessou na época:

\begin{abstract}
Curiosamente havia uma diferença de público. Era curioso porque nitidamente você tinha um público mais sofisticado no Cine Niterói e um público mais popular no Cine Jóia, e o Nikkatsu foi um cinema que ficou muito marcado pelos filmes de teor adulto, que tinha um público muito específico. Não sei te explicitar por que mais japoneses freqüentavam o Cine Nikkatsu, apesar de ser um cinema que exibia muitos filmes adultos. Porque foi no Nikkatsu que eu vi pela primeira vez um filme do Seijun Suzuki: Portal da carne, e depois História de uma prostituta. Ele e o Shohei Imamura faziam uma cinematografia mais adulta. [...] Eu ia pelo menos duas ou três vezes por semana. Tinha aquela coisa que eu gostava de freqüentar alguns cinemas pela assiduidade mesmo: entrava um filme novo no Niterói, no Nippon, eu ia lá. De vez em quando no Jóia você tinha que escolher um pouco os filmes porque passava muita merda, muito filme de carregação ${ }^{22}$. O próprio Nikkatsu era um cinema em que você não ia ver todos os filmes. Eu ia ao Nikkatsu ver filmes do Imamura. Os filmes do Seijun Suzuki etc. e tal, eu ia ver na primeira sessão.
\end{abstract}

Entre o fim da década de 1960 até meados dos anos 1970, Reichenbach participou de um movimento cinematográfico que ficou conhecido como Cinema Marginal ou de Invenção, junto com outros cineastas como Rogério Sganzerla, Andrea Tonacci, Ozualdo Candeias, Jairo Ferreira e João Callegaro. Para além das diferenças de estilos e posturas dos realizadores, o crítico e pesquisador Ismail Xavier (2001) assinala como traço comum a afirmação incisiva de um cinema realizado com orçamento mínimo, sem concessões, autoral e agressivo, descartando certas utopias do Cinema Novo quanto ao sentido da intervenção política. Em Vozes da Boca, Alessandro Gamo (2006: 11) destaca algumas referências cinematográficas do grupo: "Eram pessoas com uma bagagem cultural diversificada, freqüentadores de escolas ou seminários de cinema, cineclubes, carregadas de referências do cinema mundial, como a produção B americana, os filmes franceses da nouvelle vague e o cinema japonês".

Reichenbach afirma a influência dos cineastas japoneses Imamura, Masumura, Mizoguchi e Sugawa na realização de filmes seus como Lílian M. relatório confidencial (1975), Amor, palavra prostituta (1980), Anjos do arrabalde (1986), entre outros. A afinidade entre os filmes assistidos nos cinemas da Liberdade nos anos de formação do cineasta com o espírito do grupo do Cinema Marginal estaria relacionada com o gosto pelo choque, o questionamento dos valores morais vigentes em ambas as sociedades e com a afirmação do modo de produção independente. Lúcia Nagib (1993: 15) inicia sua descrição da nouvelle

\footnotetext{
${ }^{22}$ Esse termo, 'filme de carregação', comum no linguajar dos cineastas, pode ser interpretado a partir da fala de Olga Futemma sobre filmes japoneses de baixa qualidade: "Vi todos os grandes mestres e vi também todas as porcarias. Porcarias que eu digo são aqueles filmes do mercadão mesmo: filmes de gângsters, de cantorzinhos e comédias horríveis" (Kobayashi, 2005: 29).
} 
vague japonesa da seguinte forma: "Os tabus da moral, do sexo e da política foram atacados, os princípios comerciais desprezados, as convenções narrativas estilhaçadas. Como que arrastados numa só corrente, os velhos estúdios cinematográficos naufragaram, enquanto nascia o cinema independente".

Além do Cine Nikkatsu, havia outro ponto de conexão entre os filmes e as idéias dos jovens cineastas japoneses e brasileiros: em 1966, a convite do jornalista e editor Mizumoto, Orlando Parolini, poeta, jornalista e pesquisador de cinema japonês, passa a assinar uma coluna semanal sobre cinema na seção em português do jornal São Paulo Shimbun, convidando em seguida o amigo e crítico de cinema Jairo Ferreira para escreverem juntos. De 1967 a 1972, Jairo redige sozinho as críticas de cinema, contando com a colaboração de outros cineastas do grupo. Inicialmente, por orientação do editor, a coluna abordava preferencialmente o cinema japonês, mas foi aos poucos abrindo espaço para as produções dos jovens cineastas paulistas (Gamo, ibidem). Em Ishihara e a juventude, artigo publicado janeiro em 1967, temos uma amostra de como a conexão estabelecida no Cine Nikkatsu entre os diferentes contextos era reforçada na coluna de Jairo:

\begin{abstract}
Exploração da juventude, há pouco exibido no Cine Nikkatsu, vem confirmar a nossa alegria quanto a Shintaro Ishihara, o rebelde maldito e nebuloso de $O$ Amor aos vinte anos e Almas sedentas. Estamos diante de um filme escrito por um jovem e interpretado por jovens, mas é conveniente lembrar Condenado pela consciência, fita do jovem Uchida - um exemplo para a nossa geração - que transpira juventude aos 70 anos (...) Ser revolucionário não é só empunhar cartazes de protestos contra a guerra do Vietnã ou contra o fascismo nacional: ser revolucionário é também reconhecer a função de fitas como Explosão da juventude em nossa realidade cotidiana. Eis então uma convergência entre a realidade japonesa e a brasileira, mostrada por Ishihara através de suas preocupações com o destino da juventude (Ferreira, [1967a] 2006: 33).
\end{abstract}

Após 1967, com o despejo do Cine Nikkatsu do prédio e fracassada a tentativa do proprietário de reabrir a sala como Cine Álamo, o auditório é convertido em sede de uma igreja evangélica, a Adnipo, Igreja Evangélica Assembléia de Deus Nipo Brasileira, que até 2009 funcionava no mesmo endereço. Segundo Ricardo Gonçalves, o prédio foi comprado recentemente pela Grande Loja Maçônica do Estado de São Paulo, “[...] que vai montar lá um salão de conferências e transformá-lo em alojamento para os maçons que vem do interior participar de reuniões e assembléias no Palácio, para se hospedarem ali mesmo em frente ao Palácio”. O Palácio Maçônico havia sido fundado em 1961 em frente ao Cine Tokyo, na época em que Gonçalves atuava ali como tradutor de filmes japoneses. 


\subsubsection{Cine Nippon: filmes para chorar}

Em 1959, é inaugurado o Cine Nippon (Fig. 7), da Nippon Filmes, empresa de distribuição cinematográfica de Kimiyasu Hirata (Rodrigues, ibid). Como visto, Hirata foi um dos pioneiros do cinema japonês no país, atuando como projecionista ambulante, distribuidor de filmes japoneses e organizador de sessões de cinema japonês no pós-guerra. Localizado na rua Santa Luzia, no. 74, o Cine Nippon exibia as produções da Shochiku, a maior das produtoras japonesas do sistema dos grandes estúdios (Nagib, 1993: 21).

Desde 1958, Tsuyoshi Mizumoto, um comerciante bem sucedido, proprietário das Casas Mizumoto, mantinha negociações com a Shochiku, importando no ano seguinte um lote de 15 filmes. Num texto publicado no livro Corônia Gueinoshi (1986), ele relata que o desejo inicial era ter o Cine Jóia como exibidor exclusivo da empresa, mas com o acordo firmado entre esta sala e a Toho, fecha contrato com o Cine Nippon. A Shochiku Filmes do Brasil Importadora e Exportadora é constituída em 1961 tendo Mizumoto como presidente e com um representante do Japão. Após 20 anos, devido aos problemas de segurança na região, a Shochiku troca finalmente o Cine Nippon pelo Cine Jóia (Mizumoto, 1986). Depois do fechamento do cinema, em 1980, o prédio vira a sede da Associação Aichi do Brasil (Aichi Kenjinkai), entidade que congrega os imigrantes dessa província do Japão e seus descendentes.

Segundo Mizumoto, além da programação dos lançamentos de filmes, eram realizados shows com os atores e cantores japoneses, eventos que atraiam muitos fãs. Em janeiro de 1966, a Shochiku promoveu a vinda de Miyuki Kuwano, que, além de São Paulo, se apresentou em Mogi das Cruzes, Marília, Presidente Prudente e Londrina. O relato da experiência pessoal do então crítico de cinema do jornal O Estado de S. Paulo, Alfredo Sternheim com a visita da atriz, dá uma idéia do sucesso dessas ações:

\footnotetext{
A Shochiku um dia trouxe a Miyuki Kuwano, que era a estrela número um da companhia, uma gracinha de moça, bonita, e eu sei que fui entrevistá-la para $O$ Estado de $S$. Paulo no aeroporto de Congonhas, e tinha uma multidão da colônia que a polícia teve que fazer cordão de isolamento. Para eu conseguir chegar até a sala onde ela ia ficar e dar uma rápida entrevista exclusiva, foi um esforço, tinha que mostrar a credencial para a polícia, e aí veio o diretor da Shochiku falar com a polícia: "Não, ele pode entrar". E a multidão gritando, pedindo autógrafos e olhando pra mim e dizendo: "Quem é esse cara que furou a fila?" Foi muito legal. Foi em 1966, eu ia fazer 23 anos. Fui a um cocktail oferecido pelo consulado japonês, depois da exibição de gala, entre aspas, no Cine Coral, para convidados e tudo. Foi muito bonito (Figs. 8 e 9).
} 
Os filmes produzidos pela Shochiku e exibidos no Cine Nippon, de cineastas como Keisuke Kinoshita, Yasujiro Ozu, Heinosuke Gosho e Yôji Yamada, são classificados como cult por Carlos Reichenbach; tradicionalistas ou dramas familiares por Olga Futemma (1986); cinema intimista japonês, pelo cineasta Walter Hugo Khouri (1997); dramas intimistas por Alfredo Sternheim; e como melodramas, por Jo Takahashi.

Esta pesquisa concentra-se na manipulação ativa dos fluxos culturais por parte dos receptores (Hannerz, 1997), isto é, atenta para os esquemas locais de significação, para as interpretações dos antigos freqüentadores dos cinemas da Liberdade dos filmes, salas de cinema e outras práticas relacionadas. Nessa perspectiva, a diversidade das elaborações sobre um mesmo conjunto de filmes, assistido em uma mesma sala, não é contraditória, mas reveladora dos diversos processos interpretativos envolvidos na recepção cinematográfica.

Para Marina Narahara, os filmes mais representativos da Shochiku eram os da série $E$ triste ser homem (Otoko wa tsurai yo), produzida ao longo de três décadas. Segundo Takahashi, até seu fechamento, foram exibidos trinta episódios da série no Cine Nippon. De 1969 a 1995, foram produzidos 46 episódios da série dirigidos por Yôji Yamada com o ator Kiyoshi Atsumi. Segundo José Fioroni Rodrigues (1995), É triste ser homem tornou-se a maior série de filmes do cinema mundial.

As irmãs Clara e Teresinha Nakayama moraram com a família na Liberdade entre o início da década de 1950 até meados dos anos $1960^{23}$. Elas freqüentaram o Cine Nippon quando residiam na rua Tomás de Lima, a duas quadras do cinema. Nesta época, costumavam pegar a última sessão com o pai e a mãe. Em relação ao público freqüentador deste cinema nos anos 1960, Olga recorda-se da presença de “[...] obatchans [avós] que se moviam curvadas e reverentes entre as fileiras". Jo Takahashi fala da disposição da mãe ao choro, causada pelo sentimentalismo dos filmes da Shochiku:

[Será que era um público mais feminino que freqüentava o Cine Nippon?]

É bem possível. Senhoras. A minha mãe gostava muito, a minha mãe gostava e ela já ia preparada para chorar. As senhoras japonesas, parece que gostavam de filmes para chorar e a Shochiku fazia isso muito bem.

No Japão do período anterior à Segunda Guerra, a Shochiku teria vivido uma fase de ouro com a realização de um repertório de melodramas e histórias de amor direcionado ao público feminino. Os filmes desse gênero permaneceriam extremamente populares no pós-

\footnotetext{
${ }^{23}$ Conforme depoimento concedido por Clara (Myoko) Nakayama e Teresinha (Kyoko) Nakayama ao autor em 05/03/2009.
} 
guerra (Novielli, [2001] 2007: 116). Em 1957, o crítico de cinema Paulo Emílio Sales Gomes ([1957b] 1981: 179) identificou o "sentimentalismo lacrimoso" como a marca registrada do estilo de Tóquio, isto é, dos filmes sobre assuntos contemporâneos (os gendaigeki) produzidos na capital japonesa, onde funcionavam os estúdios da Shochiku. A característica identificada pelo crítico nos filmes japoneses repercutia também nas sessões do bairro da Liberdade: “[...] essa imagem eu tinha desde os tempos de menino: o cinema japonês era um lugar que se vai para chorar: chorar de saudade, chorar de pena, chorar de dó, uma série de coisas" (Ricardo Gonçalves).

Nos relatos de Olga Futemma e Alfredo Sternheim, a qualidade da sala e da projeção é enfatizada: a projeção em cinemascope, a construção moderna, a presença de lanterninhas elegantes e as poltronas dispostas em degraus, e não em rampas, que proporcionava conforto para a apreciação dos filmes. Na fala de Eunice Yokota, antiga freqüentadora do cine Nippon, o reencontro como o auditório deste cinema, décadas depois, marca o contraste entre o espaço lembrado e o espaço real:

O Nippon era grande, na rua Santa Luzia. Ele exibia os filmes da Shochiku, e tinha projeção em cinemascope. Era um cinema mais moderno em termos de construção (Alfredo Sternheim).

O Cine Nippon foi um furor, no tipo de organização, no tipo de luxo para nós, com lanterninhas, moças de casquete, de tailleur, indicando o lugar. Ficava na rua Santa Luzia. [Era o mais luxuoso dos quatro?] Sim. Porque o cine Jóia já existia, o Cine Niterói foi o pioneiro, o Nikkatsu ali na rua São Joaquim eu não tenho nenhuma lembrança forte, agora o Cine Nippon tinha, além das moças que levavam as senhoras até os lugares... lanterninha sempre tinha, mas essas eram distintas, lembro que eu ficava olhando. E não era uma descida, tinha degrau, portanto um certo conforto para o visionamento do filme. Não sei porque fiquei com essa idéia que o Nippon tinha um conforto diferente (Olga Futemma).

Eu lembro que o Cine Nippon, que existe até hoje o espaço, até outro dia eu fui lá, uma amiga minha convidou para um recital de canto lírico e a gente foi. Eu falei: "Ué, mas aqui é o cinema que eu vinha!". Mas é interessante que a sala é tão pequena, mas naquela época eu imaginava que a sala era enorme. Eles usam como sala pra eventos, casamentos, esse tipo de coisa. Fica na rua Santa Luzia, uma travessa da rua Conselheiro Furtado. É uma associação, Aichi Ken. Ainda tem o auditório, só que eles tiraram todas as cadeiras, porque eu acho que faz casamento, festa, mas a ainda tem o palco, onde ficava a tela (Eunice Yokota).

\subsubsection{Cine Jóia: riqueza na tela e decadência na sala}

Situado na praça Carlos Gomes no. 82, o Cine Jóia foi inaugurado em 1952, mas não como cinema japonês. Segundo Alfredo Sternheim, ele havia sido construído como cinema de bairro pela Companhia Serrador. Das quatro salas da Liberdade, era a construção mais antiga 
e comportava 987 espectadores (Futemma, 1986: 80). Em 1959, ocorre a transformação deste cinema em exibidor exclusivo dos filmes da Toho, que passa a alugá-lo (Fig. 10).

Por quase vinte anos, de 1959 a 1978, o Cine Jóia exibiu filmes dessa companhia, que contava com diretores de prestígio internacional como Mikio Naruse, Eizo Sugawa e Akira Kurosawa. Com o fechamento do Cine Nippon em 1980, a Shochiku passa a exibir seus filmes neste cinema até 1987, ano em que a sala encerra suas atividades. Nestes sete anos o cinema passa a se chamar Cine Shochiku. Atualmente, o prédio é ocupado por uma igreja evangélica.

Nas memórias sobre esse cinema há uma contradição entre a qualidade das produções exibidas - os filmes premiados internacionalmente, como os da dupla Toshiro Mifune e Akira Kurosawa - e a precariedade e decadência da sala:

O Jóia, que exibia os filmes da Toho, era na praça Carlos Gomes, na Liberdade. Ele tinha uma fachada verde, grande, linda, mas era um cinema que tinha sido construído para ser cinema de bairro da Companhia Serrador, não pra ser um cinema da Toho. E a Toho arrendou. Era um cinema grande também, devia ter uns 600, 700 lugares, com balcão e uma sala de espera muito pequena (Alfredo Sternheim).

O Cine Jóia era o Kayama Yuzo. [Passavam os filmes dele aí?] Os filmes dele, da Toho. E no Cine Jóia passava Toshiro Mifune também, eu lembro. Mifune Toshiro e filmes do Kurosawa passavam. Akahige (Barba ruiva), maravilhoso! (Marina Narahara)

As salas eram grandes, relativamente confortáveis. Só aquela do Cine Jóia que lembro que era horrível, porque era muito pequena e cheirava mal. Tinha um banheiro lá que eu acho que eles limpavam uma vez a cada quinze dias. Então, naquele cinema realmente passavam filmes interessantes, mas a sala em si era muito precária (Eunice Yokota).

Eu acho que era o cinema que exibia os filmes de melhor qualidade, cineastas consagrados e tal. Tinha dois andares, um mezanino, mas acho que era um cinema mais simples. Eu lembro já na época do declínio das salas japonesas [...] você percebia uma dificuldade de manter a programação de filmes japoneses, com o público rareando. Mas tinha uma coisa que me chamava muito à atenção, que no meio daquela precariedade sempre tinha, seja no banheiro, seja no pequeno hall, um arranjo floral, o que me dava uma idéia de resistência (Olga Futemma).

O Cine Jóia era o mais plano, dos cinemas ele era o mais desconfortável. Eu lembro que as cadeiras eram de madeira muito fina, então uma pessoa que sentava atrás e botava o joelho ou o pé, você já sentia. Mas era lá que passava os filmes do Kurosawa. Então dos cinemas é talvez o que tenha exibido o maior número de filmes de arte. Depois eu fiquei sabendo que foi o cinema predileto do Walter Hugo Khouri e do Walter Salles (Jo Takahashi).

A associação imediata entre as salas de cinema e as companhias cinematográficas, nas falas de Alfredo e Marina, mostra que a transformação dessas salas em cinemas exclusivos, exibindo por décadas apenas filmes de determinado estúdio, criou uma forte identidade entre as salas e o cinema de gênero produzido em série pelas companhias japonesas e segundo as 
mesmas fórmulas de sucesso: filmes de samurai e de yakuza da Toei no Cine Niterói; juvenis e de jovens cineastas no Cine Nikkatsu; tradicionalistas e melodramas da Shochiku no cine Nippon; e os de época e de realizadores consagrados da Toho, no Cine Jóia ${ }^{24}$.

Ricardo Gonçalves recorda que no escritório da Toho, além dos funcionários brasileiros, havia sempre uma dupla de funcionários da matriz japonesa, um chefe de escritório e um secretário, enviados para o Brasil. O proprietário do Cine Jóia era um 'brasileiro', Roberto Corrêa, que trabalhava diariamente no escritório da companhia. Num encontro fortuito na rua nos anos 1980, Gonçalves perguntou se ele gostaria de ter continuado a trabalhar com cinema, e Corrêa disse que tinha mudado para o ramo de seguro porque era mais seguro. O ex-tradutor dos filmes da Toho relembra um episódio envolvendo Corrêa, que, além de proprietário da sala acabava fazendo um pouco de tudo:

Tinha um rapaz brasileiro que era o dono do prédio do Cine Jóia. E ele trabalhava para a Toho também, ajudava a vender os filmes, administrava o cinema, a sala, e ele resolveu traduzir filmes a partir do inglês. "Ah, manda o texto em inglês que eu traduzo". E ele traduziu um filme policial. Aí mandou para o laboratório e tudo, então me lembro que era um filme de gângster, tinha uma cena que um gângster dizia para o outro: "Você trouxe a sua espingarda?", e o outro respondia: "Trouxe, está aqui". Põe a mão no bolso e tira uma pistolinha pequena e em inglês estava escrita a palavra gun [risos].

O escritor Cláudio Willer, freqüentador dos cinemas e restaurantes japoneses da Liberdade no início dos anos 1960, lembra das traduções e legendas dos filmes japoneses antes do aparecimento de Gonçalves:

O Cine Jóia que era mais antigo, antes de virar cinema de filmes japoneses já existia como cinema de filme classe B. [...] Agora, algo que eu lembro que era muito engraçado, era o seguinte: até entrar em cena o Ricardo Gonçalves, as traduções! As traduções estavam no limite do ininteligível. Eles mesmos traduziam de qualquer jeito, porque tinha que legendar [risos]. Já que era para a colônia japonesa, então eram traduções esquisitíssimas os primeiros, aí depois acertaram quando entrou em cena o Ricardo Gonçalves ${ }^{25}$.

Gonçalves atribui sua boa reputação como tradutor de filmes japoneses a um conselho dado pelo Sr. Oshida, um antigo funcionário do escritório da Toho no Brasil:

\footnotetext{
24 “O mercado cinematográfico, da produção à distribuição, era dominado pelas cinco 'majors companies' japonesas: a Shochiku, a Nikkatsu, a Daiei, a Toho e a Toei. Era uma espécie de eco distante das cinco majors americanas, estruturando-se como estas sobre o cinema de gênero. (...) no Japão cada uma das empresas investia em gêneros específicos. O forte da Shochiku, por exemplo, sempre foi o gendaigeki (drama contemporâneo), que incluía o shomingeki (drama do povo) e o kazokumono (drama familiar), entre outros. A Nikkatsu, responsável antes da guerra por uma grande produção de filmes de chanbara (luta de espadas), foi incorporada pela Daiei de 1942 a 1954. Esta, formada durante a Segunda Guerra, dividiu-se entre o jidaigeki (drama de época) e o gendaigeki. A Toei, sediada em Kyoto, antiga capital japonesa, desenvolvia sobretudo o jidaigeki. A Toho (...) especializou-se em jidaigeki e em filmes de monstros (lançou, por exemplo, a série Godzilla)" (Nagib, 1995, 65).

${ }^{25}$ Conforme depoimento concedido por Cládio Willer ao autor em 25 de junho de 2009.
} 
Tinha um funcionário issei [imigrante] antigo, o sr. Oshida, que era encarregado não só da venda dos filmes para os distribuidores, mas também era quem cuidava da parte técnica das legendas. A gente trabalhava assim: o seu Oshida me passava o daihon, que é o script. Eu me lembro de uma instrução que ele me deu logo no início: "Você precisa prestar atenção no comprimento das frases. Você deve fazer frases e contar 35 letras e espaços, não mais que isso. Você pode fazer legenda de duas linhas com 35 letras em cada linha. Se passar disso o laboratório corta de qualquer jeito que eles não querem nem saber do sentido". Desde que ele me disse isso eu já tinha essa coisa na cabeça: não era para traduzir ao pé da letra. Se traduzisse ficava uma frase quilométrica e não caberia ali. Então eu tinha que resumir às vezes frases imensas em duas linhas de 35 letras. Aí no laboratório faziam direitinho. E percebi que muitos tradutores tinham dificuldade porque nunca ligaram para esta parte técnica. O sr. Takeshita, que foi o primeiro tradutor, ele não dava a mínima para isto, traduzia as coisas ao pé da letra e tinha muita má fama como tradutor porque as frases saíam cortadas, incompreensíveis, não era culpa dele, era culpa do laboratório que cortava de qualquer jeito.

\subsection{Nodo-jiman, shows com atores-cantores e rádios nikkeis}

Ricardo Gonçalves aprendeu japonês nos mangás, com a ajuda dos colegas nikkeis do secundário, cursado no antigo colégio Roosevelt, no parque Dom Pedro. Em meados dos anos 1950, a maioria dos alunos do Roosevelt eram filhos de japoneses, de famílias que trabalhavam no Mercado Municipal da rua Cantareira, um dos principais núcleos de concentração dos japoneses e descendentes na cidade e por onde circularam os feijões que ergueram o Cine Niterói. A partir do mangá Gonçalves passa a se interessar pela cultura artística japonesa: dança, música folclórica, teatro tradicional e o cinema. Lembra-se das livrarias japonesas que importavam e vendiam livros, revistas, mangás, discos musicais e fotografias dos atores-cantores:

Como eu gostava muito de freqüentar livrarias atrás de mangás, eu descobri que existiam livrarias lá na rua Conde de Sarzedas e arredores, como havia livrarias também na região do Mercado Municipal. [...] As livrarias japonesas que existiam tanto na zona do Mercado como na Liberdade funcionavam também como casas de discos, então ali tinha acesso a discos e fotos de artistas de cinema, inclusive vendiam-se muitas fotos de atores e atrizes, fotos da Misora Hibari, foi aí que eu conheci a Hibari.

$\mathrm{O}$ ex-tradutor dos filmes dos filmes da Toho assinala a principal diferença entre as salas da Liberdade e os demais cinemas da cidade:

Os cinemas normais, eram só cinema. Agora, os cinemas japoneses funcionavam também como salas de espetáculos ao vivo. Tinham programas de calouros, na época havia muitos programas japoneses em estações de rádio, e essas organizações que faziam programas de rádio em japonês também usavam as salas de cinema para fazer programas de calouros, eventualmente um show com algum cantor ou ator vindo do Japão e essas atividades extras eram geralmente aos domingos de manhã. Como eu gostava de música [risos], também me aventurava aí, também cheguei a cantar em programas de calouros. 
Cláudio Hirai, neto de um dos fundadores do Cine Tokyo-Nikkatsu, recorda que nas manhãs de domingo aconteciam os nodo-jiman no auditório do cinema, concursos em que os cantores se apresentavam com orquestras e cada cantor representava uma região - capital, noroeste, sorocabana e norte do Paraná. Estas apresentações musicais eram gravadas e transmitidas no dia seguinte em programas radiofônicos falados em japonês, como o da Rádio Cometa. Shuhei Hosokawa, que realizou pesquisas sobre música e cinema japoneses no Brasil, observa o papel desempenhado pelos concursos de canto, os nodo-jiman, nas difusões de rádio nikkei transmitidas em japonês:

No terceiro concurso surgem cinco emissoras de rádio nikkei: a Cultura, a Difusora, a Excelsior, a Panamérica e a São Paulo, com patrocinadores. Todas elas tinham transmissão diária em língua japonesa com uma hora de duração. Difusões de rádio nikkei começaram em 1947 em Araçatuba e em sua fase áurea (fins dos anos 1950 e primeira metade dos anos 1960), contavam com dez emissoras, mas perderam força devido à pressão contra emissões em língua estrangeira em 1966. Um dos programas de sucesso nesta fase áurea era o concurso de amadores, transmitido ao vivo no domingo de manhã dos cines Niterói e Nippon, no bairro da Liberdade (Hosokawa, 1993: 139).

Como no episódio relatado por Sternheim sobre a vinda da atriz e cantora Miyuki Kuwano ao Brasil promovida pela Shochiku, Gonçalves observa que a Toho também promovia com frequiência a vinda de atores e atrizes, que também eram cantores, ao país. Os espetáculos musicais ocorriam no próprio Cine Jóia ou no Teatro Brigadeiro, alugado para essas ocasiões. O depoimento de Marina Narahara sintetiza a conexão entre cinema e música no Japão e entre as salas de cinema, os programas de rádio nikkeis e a vinda de astros e estrelas japoneses ao Brasil:

Tem um ator chamado Kayama Yuzo, que também estourou, também fez um sucesso danado com uma série de filmes chamados Wakadaishô e juntamente com a música que fez sucesso que ele cantava também. Ele veio para o Brasil, e aí eu fui comprar entrada para assistir o show dele. Então tinha que comprar lá no Cine Jóia mesmo, lá na bilheteria. E quem comprasse entrada concorria a um sorteio para ir buscar o Kayama Yuzo, até lá no Viracopos. Aí um dia eu estava ouvindo rádio, porque naquela época todo mundo ouvia rádio, era um programa falado em japonês, mas eu sei que falou meu nome, fui sorteada para ir lá. E a gente foi até Viracopos onde ele desceu. E levamos flores e voltamos para Congonhas junto com o grupo. Eu vou mostrar, tem foto, eu tirei foto do Kayama Yuzo. Isso aqui é em Viracopos. Essa aqui sou eu, eu usava óculos. Aqui é uma homenagem que se fez lá no Bunkyo, porque eu frequientava a associação lá do Bunkyo, um grêmio que eu freqüentava. E o pessoal fez, não sei se era o aniversário dele. [E você ficou emocionada?] Nem um pouco. Ele é lindo demais, é muito bonito, só que ele foi muito antipático, ninguém gostou dele, você vê pela cara dele. Acho que é muito assédio e aí ele começou a tratar assim de qualquer jeito. Então não foi muito lá grande coisa, não (Figs. 11 e 12). 


\subsection{Paquera nas filas dos cinemas, bailes nikkeis e piqueniques}

$\mathrm{Na}$ maioria das fotografias dos cinemas da Liberdade ou ainda nas imagens recriadas por seus antigos frequientadores, as filas são um tema recorrente (Figs. 13 e 14). No entanto, as filas a que se referem esses espectadores não são iguais às filas atuais, para entrar em salas de cinema multiplex, com capacidade para cem ou trezentas pessoas - eram salas de mil ou 1.500 assentos. Se hoje as falas que descrevem filas quilométricas que dobravam o quarteirão soam exageradas, descreviam apenas a realidade em relação ao tamanho dos antigos cinemas. Nas sessões mais concorridas, passava-se um bom tempo nas filas. Num contraponto à banalização do ato de ir ao cinema nos dias atuais, Olga Futemma lembra-se da preparação pessoal, do cuidado com o vestuário. Ela recorda também outra prática associada, a paquera na fila:

[...] então tinha todo um jeito: arruma-se o cabelo, a roupa, contando-se inclusive com a parada na fila, porque era o momento de olhar e ser olhado. E sim, aconteciam paqueras. Às vezes os rapazes ficavam do outro lado da calçada, encostados em um carro, ou em um bar na esquina, só 'bisoiando' as mocinhas na fila com as suas famílias, então era muito divertido (Fig. 15). Um pouco depois os clubes de jovens nisseis se organizaram: Piratininga, Paratodos, meus irmãos freqüentaram, eu não. Talvez uma ou outra vez e quando começaram a ter os bailes numa puxada bem ocidental, já. Mas até então, era nos cinemas que acontecia a paquera mesmo.

Olga associa as sessões de cinema da Liberdade aos primeiros bailes nikkeis promovidos na época, em meados dos anos 1960. A junção destes elementos parece constituir uma experiência marcadamente da juventude de parte dos nisseis no pós-guerra, isto é, dos filhos de imigrantes que cresceram na cidade de São Paulo ou que aqui vieram estudar e que mesmo freqüentando escolas da rede de ensino brasileira, mantinham relações de sociabilidade e práticas de lazer em torno de associações juvenis ou de clubes nikkeis como Piratininga, Paratodos ou o grêmio do Bunkyo. Os depoimentos de Marina Narahara, e das irmãs Clara e Teresinha Nakayama estabelecem uma conexão entre os bailes e as excursões ou piqueniques promovidos por grupos de jovens:

[E lá no Bunkyo o que é que vocês faziam nesse grêmio?]

No grêmio? Ah no grêmio a gente... nossa! Antigamente tinha várias atividades, tinha bailes, sabe? Sabe a Casa de Portugal, na Avenida Liberdade? Uma vez por ano a gente fazia 'Uma Noite em Tóquio', a gente fazia um baile lá. Era época de bailes, dos bailinhos na Liberdade [Nos anos 1970?] É, anos 1970, 1969, 1968, eu freqüentava lá. E a gente montava aquelas flores para enfeitar tudo porque era 'Uma Noite em Tóquio', então tinha que ser um motivo japonês. E a gente viajava muito, para Campos do Jordão, Itatiaia, escalava montanhas, mas só os japoneses do grêmio. [Uma turma de nisseis?] Todos nisseis. [Vocês se falavam em português?] Só em português, ninguém falava em japonês. Aliás, pouca gente fala japonês até hoje. (Marina Narahara) 
[Vocês freqüentaram aqueles bailes nikkeis?]

Clara: Piratininga nunca, nem o Paratodos, mas eu freqüentava bastante os da Liberdade, a Liga Itálica, a Casa de Portugal. ['Uma Noite em Tóquio'?] 'Uma noite em Tóquio' eu não fui, mas a gente freqüentava bastante os bailes de lá. Porque o meu irmão é cabelereiro, então ele freqüentava muito esse meio dos cabelereiros que na época fazia bastante sucesso. Então tinha formatura das escolas, desfiles e era sempre com um baile, que fazia parte destes eventos, então a gente freqüentava muito. E tinha também os bailes da Liga Itálica, que tinha colônia japonesa. [Então o lazer nesta época eram estes?] Cinema, bailes e tinha os piqueniques, nós éramos os farofeiros da época.

Teresinha: Ah é, a gente ia muito em piquenique!

Clara: Hoje em dia falam que é farofeiro, na época falava piquenique [risos].

Teresinha: Eles alugavam um ônibus e nós íamos de ônibus.

Clara: Era um grupo, às vezes era uma associação, um grupo de amigos, arrumavam um grupo de pessoas, alugavam um ônibus e cada um preparava o seu bentô e ia embora. [Para onde vocês iam?] Para a praia, a gente ia muito para a praia e para Valinhos.

Teresinha: Nós fomos para Valinhos e fomos uma vez para Campos de Jordão também.

\subsection{As salas da Liberdade e o circuito de projeções ambulantes}

As salas de cinema 'fixas' do bairro da Liberdade não substituíram ou sucederam temporalmente as projeções ambulantes de filmes japoneses realizadas nas cidades do interior paulista e nos bairros da capital com concentração de japoneses e nikkeis, assim como a concentração do comércio japonês no entorno do Cine Niterói, na rua Galvão Bueno, não desativaria de imediato o primeiro bairro japonês do entorno da rua Conde de Sarzedas. No pós-guerra, os dois núcleos coexistiram por mais de uma década (Negawa, 2000).

Segundo Tomoo Handa (1987: 590), no início da década de 1930, Pinheiros era a segunda região onde mais havia japoneses e descendentes na cidade de São Paulo, abrigando $10 \%$ dos cerca de 2.000 residentes na capital, ou um terço da população da região da rua Conde de Sarzedas. Ele descreve o bairro na época, cujo comércio japonês foi impulsionado pelo movimento dos cooperados em torno da Cooperativa Agrícola de Cotia:

Pinheiros também tinha de tudo em matéria de comércio para satisfazer as necessidades diárias dos japoneses: restaurantes, doceiras, mercearias de artigos japoneses, barbearias, casas de tofû [...] Um passo fora de Pinheiros e já era o interior, sendo que ainda havia numerosos agricultores japoneses no Butantã, Caxingüi, Taboão da Serra e Campo Limpo.

Como visto, após a transferência do escritório da Nippaku Shinema-sha de Bauru para São Paulo, em 1933, a empresa passa a promover sessões na capital. De acordo com Kimiyasu Hirata, além das sessões no bairro da Liberdade [Cine Theatro São Paulo], o circuito das projeções ambulantes incluía na época exibições em escolas japonesas de Cotia, Jaguaré e Vargem Grande Paulista; na Cooperativa Agrícola de Cotia, em Pinheiros; na 
Cooperativa de Mogi das Cruzes, em Cocuera [bairro rural deste município]; e em chácaras nos bairros Morumbi e Brooklin.

No pós-guerra, o circuito de projeções ambulantes continuou funcionando, e uma prova de sua vitalidade foi a inauguração, em 1953, no mesmo ano do luxuoso Cine Niterói, do Cine Brasilândia (Simões: 1982, 154 e 158): um galpão de madeira que abrigou o primeiro cinema da Vila Nova Brasilândia, bairro da zona norte de São Paulo, construído pelos japoneses e nikkeis residentes na região (Fig. 16). Desde 1933, oito anos antes do primeiro loteamento do bairro, eles mantinham uma associação própria, a Associação Nipo-Brasileira.

Com a evacuação da rua Conde de Sarzedas em 1942, outra região que passou a concentrar as famílias de imigrantes japoneses foi a que compreende os bairros da Saúde, São Judas Tadeu, Conceição e Jabaquara. Aos oito anos de idade Jo Takahashi ia sozinho aos cinemas da Liberdade pesquisar filmes japoneses que seriam exibidos em seu bairro: paralelamente à escola primária, ele freqüentava uma escola japonesa no bairro de São Judas Tadeu, a São Judas Gakuen,

[...] que organizava atividades de integração dos alunos com os pais [undokais] e todos nós éramos convidados a participar. Era necessário uma verba, e éramos também convidados a levantar estes fundos. Um dos mecanismos para isso era a exibição de filmes japoneses. $\mathrm{O}$ sensei então fazia um contato com os donos do cinema da Liberdade, alugava o filme e o local para a exibição. Geralmente era uma igreja, ou então uma escola que emprestava o auditório.

Os convites para estas sessões eram vendidos pelos alunos de casa em casa no perímetro do bairro. "O sensei preferia dramas, melodramas, e nós, as crianças, preferíamos filmes de ação (risos). Então a gente começou a impor um pouco: 'Olha, se o senhor quiser que a gente venda os ingressos, a gente vai querer opinar sobre os filmes selecionados"”.

Segundo Futemma (1986: 79), a presença dos ambulantes nos kaikans [clubes] das cidades do interior era fundamental para a continuidade de circulação dos filmes: em 1959, em plena 'época áurea' dos cinemas da Liberdade, a distribuidora do Cine Nippon contava com quatro funcionários ambulantes e a Toei tinha um projetor próprio para essas sessões. Ricardo Gonçalves dimensiona a importância do circuito de projeções nas cidades do interior paulista na década de 1960, apontando sua capilaridade:

Tínhamos os escritórios centrais aqui em São Paulo, da Toho, da Shochiku, etc. e as redes no interior, então havia exibidores que atuavam nas cidades do interior com colônia japonesa, alugavam cinemas ou então arrumavam um projetor e passavam os filmes nos kaikans, nos centros sociais. Grande parte dos clientes da Toho eram estes exibidores do interior que vinham periodicamente à São Paulo, alugavam os filmes, que eram despachados por via rodoviária ou por trem $[\ldots]$ 
Gonçalves se recorda de uma senhora de Mogi das Cruzes, Saiga-san, "uma imigrante antiga que vinha uma vez por mês na Toho buscar filmes para passar em Mogi e arredores". Tratava-se de sessões com fins lucrativos, fonte de renda para os exibidores, o que atesta a sua regularidade: "Tinha gente que vivia disto, ou pelo menos era uma atividade subsidiária, uma renda extra, porque eram sessões pagas, pagava e entrava para assistir, não eram grátis."

O funcionamento dos cinemas da Liberdade e a instalação dos escritórios das companhias cinematográficas japonesas na capital paulista operaram uma transformação na dinâmica de circulação dos filmes japoneses no estado de São Paulo. Segundo Kimiyasu Hirata, nas décadas de 1930 e 1940, as empresas distribuidoras brasileiras compravam cópias de filmes japoneses de segunda mão, que por sua vez eram exibidas primeiramente nas regiões das linhas ferroviárias Noroeste, Mogiana e Paulista e só depois chegavam à cidade de São Paulo. No pós-guerra a parceria entre Hirata e Saito durou até 1952. A separação teria se dado devido a divergências na condução dos negócios: ainda naquela época a maioria dos filmes era recomprada da Nichibei Cinema-sha, de Los Angeles (EUA), ou seja, eram cópias "velhas e desgastadas" (Hirata, 1986).

Ao montar a sua empresa, a Nippon Cinema-sha, Hirata centraria esforços na importação direta junto a diversas produtoras japonesas, como a Daiei e a Shochiku. O sucesso comercial das sessões promovidas por empresas como a de Kimiyasu teria levado as companhias produtoras japonesas (Toho, Shochiku, Nikkatsu e Toei) a abrirem distribuidoras no país, transformando as salas da Liberdade em cinemas exclusivos. A partir daí a dinâmica de circulação se inverte: cópias novas, de filmes contemporâneos, são exibidas antes em São Paulo, no bairro da Liberdade, seguindo depois para as projeções ambulantes nas outras regiões da capital e nas cidades do interior paulista.

\subsection{Cinema, ritual e experiência}

Parte dos entrevistados refere-se à experiência de freqüentar os cinemas da Liberdade como um ritual. A partir do aparecimento deste termo como categoria nativa desses sujeitos, passa-se agora a interpretar alguns dos significados contidos nessas expressões, assim como a estabelecer algumas relações analógicas entre o ato de ir ao cinema com a dimensão ritual, tal como analisada pelo antropólogo Victor Turner tanto nas sociedades tribais ou agrárias quanto nas sociedades industriais contemporâneas ([1969] 1974 e 1974). 
Um primeiro paralelo entre cinema e ritual relaciona-se com a preparação pessoal, o cuidado com o vestuário em uma situação pública extraordinária, como no caso de uma festa:

Essa experiência de ir com a família toda ao cinema em bases regulares, tem uma coisa ali de ritual que eu acho maravilhoso! [...] Para as gerações de hoje deve ser esquisito você se aprontar para ir ao cinema. Mas de fato era um evento, sobretudo para as moças, os rapazes também iam de terno, então tinha todo um jeito, arruma-se o cabelo, a roupa [...] (Olga Futemma).

Como Olga, Ricardo Gonçalves contrapõe a relação atual das pessoas com os filmes com o caráter coletivo e extraordinário da experiência de ir ao cinema no passado, que demandava uma preparação ritual:

É uma experiência coletiva e a própria preparação para ir ao cinema, quer dizer, hoje ver um filme é uma coisa tão banalizada e corriqueira que você aperta um botão e está vendo. Não, naquele tempo era se vestir de uma maneira especial, vestia roupa social, porque inclusive tinha cinemas que proibiam a entrada de pessoas sem gravata. Então o cinema era cercado por uma série de barreiras, inclusive você tinha que se preparar para entrar neste espaço. Tem este aspecto também de ritual.

Ao analisar as reminiscências de velhos sobre filmes, trajetos e espaços cinematográficos na cidade de São Paulo, Ramos (2008) argumenta que na época do apogeu dos cinemas da Cinelândia Paulista, entre as décadas de 1930 e 1960, ir ao cinema era um acontecimento, ou uma atividade excepcional, diferente das atividades rotineiras. A preocupação com a vestimenta por parte dos freqüentadores dos cinemas japoneses corresponderia talvez ao decoro observado nos cinemas do centro da cidade: "Era muito importante estar sempre 'bem vestido' para entrar neles (cinemas), o que, em termos de regra explícita, significa que os homens tinham que usar terno e gravata ou seriam barrados pelo porteiro" (Almeida, 1995: 53). "Nas salas da Cinelândia havia a imposição de certo decoro para freqüentar as sessões. Homens não entravam sem paletó e gravata e as mulheres vestiamse com distinção para a ocasião" (Ramos, 2008: 123).

Uma segunda analogia entre cinema e ritual corresponde à assiduidade ou regularidade do ato de ir ao cinema, e que se manifesta na expressão "ir religiosamente". Como no caso desta fala de Jo Takahashi a respeito das sessões de cinema japonês que ocorrem atualmente na Fundação Japão, freqüentadas principalmente por idosos:

Dentre o público que é freqüentador assíduo desta sala, muitos deles comparecem em quase todas as sessões, independente se o filme é de samurai, se é de época, ou se é um mangá ou um animê. Então acho que isso mostra que a relação das pessoas com o cinema é uma relação que transcende até o próprio filme, e acho que é uma relação muito com o ritual, de você freqüentar o lugar e ter uma diversão garantida nessas sessões. [O sentido de ritual 
neste caso seria como ir religiosamente à missa?] Isso, exatamente. Independe do sermão do padre, se o padre é bonito ou não [risos].

Há um trecho do depoimento de Ricardo Gonçalves em que ele rememora situações ocorridas em cidades do interior paulista, em que "fervor religioso" dos japoneses e nikkeis pelo cinema japonês teria eclipsado a sua pregação de monge budista:

E quando se passava um filme numa cidade do interior fechava tudo, todo mundo ia religiosamente para o kaikan ou para o cinema para assistir ao filme. Eu me lembro, 1961, 1962, 1963, eu já estava atuando no templo budista. E eu, sozinho ou com outros monges, fazia visitações ao interior para pregar o dharma, pregar o budismo. A gente tinha que elaborar um plano com cuidado para não coincidir a nossa presença com a exibição de filmes, que algumas vezes aconteceu. A gente chegava lá, o encarregado que nos recebia dizia: "Hoje não dá, tem cinema e não vai ter ninguém para te ouvir, está todo mundo no cinema". Dito e feito, naquele dia não aparecia ninguém.

Estes episódios apontam para o caráter de experiência coletiva das sessões de filmes japoneses no meio rural, vivida em comum por "todos" os japoneses e nikkeis da localidade. Nesse sentido, aproximam-se das características dos fenômenos liminares das sociedades préindustriais estudadas por Turner (como se verá adiante), ou seja, há produção de símbolos que evocam significados intelectuais e emotivos comuns a todos os membros do grupo (Dawsey, 2005: 168). O envolvimento dos participantes das sessões na construção do espaço de exibição reforçaria seu caráter comunitário: "Acho que a itinerância do cinema-ya, como era chamado, tem características muito semelhantes ao circo: monta-se o picadeiro, então tem todo o envolvimento da comunidade local para a construção do espaço aonde vai acontecer o espetáculo" (Jo Takahashi).

Ao falar sobre sua experiência pessoal com os cinemas da cidade de São Paulo, Takahashi aborda um outro aspecto da relação entre cinema e ritual que qualifica como “solene". Das sessões de cinema fora da Liberdade, Jo lembra dos cinemas com projeção em cinerama ou em 70 milímetros do centro da cidade. A descrição que ele faz do início dessas sessões remete a uma descrição etnográfica das diferentes fases de um rito:

Começava com um gongo, todo cinema tinha um gongo. E nesses filmes era muito frequiente ouvir a trilha sonora de abertura, sem a projeção do filme. A luz do cinema ia caindo, bem aos poucos depois do gongo, e eles lançavam a trilha sonora, isso para criar um envolvimento, uma expectativa, uma ambientação, e a gente já ia entrando no clima do filme. E quando acabava a trilha sonora a cortina se abria e começava o filme. Era muito solene, era muito parecido com ópera.

Em outra correspondência com o trabalho de Ramos o "tempo de espera" é recordado de forma semelhante: "Neste momento de espera tocavam-se músicas ao vivo ou reproduzidas 
por um dispositivo qualquer. Tal como no teatro ou nas óperas, um sinal tocava três vezes antes da projeção. No último toque as pessoas se aquietavam em suas poltronas e a luz da sala escurecia” (Ramos, 2008: 138). Segundo o autor, mais do que separar uma sessão da outra este tempo de espera exercia uma função psicológica ao preparar os sentidos e os sentimentos da platéia para o filme que iria começar. Sem ele a audiência não teria tempo suficiente para se desligar das coisas do mundo que havia deixado para trás.

Uma metáfora possível para as situações descritas é a da porta da igreja católica, que não é uma porta ordinária, mas uma espécie de ante-sala, de modo que o espaço-tempo sagrado e o profano não entrem em contato direto. Nessa linha, Ricardo Gonçalves apresenta sua definição de rito, reforçando o paralelo com o cinema:

$\mathrm{O}$ cinema tem isso também, porque o que é o rito? O rito é um conjunto de gestos, palavras e manipulações de objetos em que você entra em outro tempo e outro espaço. O cinema te propicia isto, entrar em outro tempo e outro espaço. [...] E é alguma coisa mágica, que mexe com o imaginário, que realmente te introduz num outro espaço e num outro tempo, que não tem nada a ver com esse tempo banal, cotidiano em que você se arrasta todos os dias. Você conhece as teorias do Mircea Eliade, o historiador das religiões, sobre tempo sagrado e espaço sagrado? Isso cabe muito bem aí. [...] O tempo do cinema como uma espécie de tempo sagrado. Um outro tempo, ontologicamente muito mais denso do que esse tempo cotidiano que você experimenta como uma coisa degradada, sem sentido algum.

Se, como argumenta Ramos (2008), o cinema é um ato de rememoração ou reapresentação de eventos filmados no passado, assistir a qualquer filme, mesmo no caso de um lançamento, nos remete necessariamente a um outro tempo. Em relação ao espaço, nos cinemas da Liberdade as pessoas eram de fato "transportadas" para outros contextos, paisagens, cenários e locais, reais ou imaginários, e em sua maioria relacionados ao Japão, onde foram produzidos os filmes exibidos nessas salas.

Há na fala de Gonçalves, no entanto, uma distinção significativa entre o tempo "banal", "arrastado", "degradado" e "sem sentido" da vida cotidiana e o tempo "adensado" experimentado no cinema, decorrendo daí comparações entre este e o tempo sagrado. Mas a oposição entre sagrado e profano, formulada por autores como Mircea Eliade, seria adequada para pensar a experiência da recepção cinematográfica de maneira geral? Isto é, será que a exibição de qualquer filme japonês propiciaria esta qualidade de experiência? Era algo que ocorria com frequiência e para todos os freqüentadores desses cinemas? Talvez uma outra vertente de reflexão sobre o sagrado, o estudo antropológico dos rituais de Victor Turner, possa auxiliar na compreensão desta questão. 
Em O Processo Ritual, Turner ([1969] 1974) analisa a estrutura simbólica do ritual ndembo e algumas particularidades sociais da fase liminar do ritual. Seu olhar se dirige às dimensões extraordinárias do cotidiano: as estruturas sociais revelam-se com intensidade maior em momentos extraordinários, que se configuram como manifestações de anti-estrutura (Dawsey, 2005: 165). Para ele, a experiência de vida de cada indivíduo o expõe, de forma alternada, a dois modelos justapostos de correlacionamento humano, "estrutura" e "communitas":

O primeiro é o da sociedade tomada como um sistema estruturado, diferenciado e hierárquico de posições político-jurídico-econômicas. [...] O segundo, que surge de maneira evidente no período liminar, é o da sociedade considerada como um comitatus nãoestruturado, ou rudimentarmente estruturado e relativamente indiferenciado, uma comunidade, ou mesmo comunhão de indivíduos iguais que se submetem em conjunto à autoridade geral dos anciãos rituais (Turner, 1974: 119).

Nas sociedades agrárias ou tribais, as mudanças de posições sociais ocorrem por meio dos ritos de passagem. Neles, seus beneficiários adquirem os atributos sagrados que caracterizam todas as posições numa estrutura social. As passagens ocorrem por intermédio de um limbo de ausência de "status": "As entidades liminares não se situam nem aqui nem lá; estão no meio e entre as posições atribuídas e ordenadas pela lei, pelos costumes, convenções e cerimonial" (Dawsey, 2005: 117). Assim, “communitas" se manifestaria em fenômenos liminares como na fase de margem dos ritos de passagem, em que os sujeitos rituais passam por um processo de homogeneização e criam entre si sentimentos intensos de camaradagem e igualitarismo.

Para Turner, esta qualidade existencial de "communitas", que abrangeria a totalidade do homem em sua relação com outros homens inteiros, é geradora de símbolos, metáforas e comparações. A arte e a religião seriam produtos dela, mais do que das estruturas legais e políticas:

A liminaridade, a marginalidade e a inferioridade estrutural são condições em que frequientemente se geram os mitos, símbolos rituais, sistemas filosóficos e obras de arte. Estas formas culturais proporcionam aos homens um conjunto de padrões ou de modelos que constituem, em determinado nível, reclassificações periódicas da realidade e do relacionamento do homem com a sociedade, a natureza e a cultura (Turner, ibidem: 157).

O autor estende a noção de "communitas" para as sociedades pós-industriais, abrangendo a análise de diferentes tipos de fenômenos: através de ritos, cultos, festas, carnavais, música, dança, teatro, procissões, rebeliões e outras formas expressivas, a sociedade pode ver-se a si mesma a partir de múltiplos ângulos, provocando efeitos de paralisia em 
relação ao fluxo da vida cotidiana. Nestas situações, universos sociais e simbólicos são recriados a partir de elementos do caos (Dawsey, ibidem: 165).

Turner comparou sistemas simbólicos de culturas que se desenvolveram antes e depois da revolução industrial. No prefácio de Dramas, Fields and Metaphors: Simbolic Action in Human Society (1974), as idéias sobre os gêneros liminóides de ação simbólica haviam sido apresentadas:

Gêneros que floresceram desde a Revolução Industrial (as artes e ciências modernas), embora menos sérios aos olhos da população geral (ciência pura, entretenimento, interesses da elite), têm apresentado um potencial maior para transformar os modos como as pessoas se relacionam entre elas e o conteúdo de suas relações. Manifestam-se em espaços exteriores às arenas centrais da produção industrial [...] a sua própria exterioridade a libera da atividade funcional em relação ao pensamento e comportamento dos membros da sociedade. Constituem para seus agentes e audiências uma atividade optativa - a ausência de obrigações ou constrangimentos advindos de normas externas lhe confere uma qualidade prazerosa que favorece a sua absorção nas consciências individuais. Dessa forma o prazer se torna assunto sério no contexto de mudanças inovadoras (Turner, apud Dawsey, 2005:167) [grifo do autor].

Turner observou essa qualidade prazerosa associada aos gêneros liminóides principalmente no teatro, empenhado que estava na formulação de uma antropologia da performance $^{26}$. E quanto ao cinema? Há, em primeiro lugar, aquela fala de Takahashi em que ele associa ritual com "freqüentar o lugar e ter uma diversão garantida nessas sessões".

Em Cinema em São Paulo - Hábitos e representações do público (Anos 40/50 e 90) (1995), ao descrever o fascínio que o cinema continua exercendo em seu público, Heloísa Buarque de Almeida elabora algumas metáforas relacionadas à magia, ao ritual e ao sagrado:

Não é raro que ainda hoje se comente o caráter mágico da sala escura, com uma "quasecomunhão" com outros espectadores por todos concentrarem-se na mesma história neste local; mágico também pelas sombras e luzes projetadas na tela como fantasmas. Acrescentese a isso o programa que consiste no ato de "ir ao cinema", opondo-se ao comodismo de assistir a um filme na televisão ou no vídeo e saindo da rotina (Almeida, 1995: 2) [grifo do autor].

No capítulo "A demarcação da passagem do tempo: hábitos da infância e da juventude" há um subitem que se inicia com o título: "Adolescência e juventude, quando o cinema era sagrado". Nele, a autora observa que na fase em que os entrevistados classificam como adolescência, juventude ou mocidade, o cinema era considerado "um programa especial e divertido". Em outro trecho, Almeida comenta um episódio de significação ritual na história

\footnotetext{
26 "Campo de estudo que surge no diálogo entre antropologia e o teatro nos anos 1970, a partir do encontro e colaboração entre Victor Turner e Richard Schechner” (Dawsey, ibidem: 166).
} 
de vida de uma de suas entrevistadas, cujo efeito, talvez semelhante ao de um baile de debutantes, revela uma menção implícita aos ritos de passagem:

Para alguns, há uma espécie de "passagem" que marca a entrada nessa fase. Um exemplo desse ritual aconteceu na primeira vez que uma informante foi ao cinema à noite, acompanhada pelos tios, numa cidade de interior, o que lhe proporcionou uma emoção especial e a fez sentir-se uma "mocinha" (idem, ibidem: 83) [grifo do autor].

A autora argumenta que ao ingressarem na adolescência, aos 13 ou 14 anos, seus informantes começaram a ir sozinhos ao cinema, isto é, na companhia de colegas, amigos e namorados, sem a presença da família. É nessa fase que muitos deles "realmente se apaixonam pelo cinema", fato relacionado ao desenvolvimento de um gosto pessoal, embora outros se sentissem obrigados pela imposição da moda (Almeida, 1995: 87).

Nas reflexões sobre os sentidos do ato de ir ao cinema, a qualidade prazerosa dos gêneros liminóides apontada por Turner, que favoreceria sua absorção nas consciências individuais, torna significativa a associação entre idéias de universos aparentemente tão distintos, como "ritual" e "diversão" ou "sagrado" e "divertido".

Marina Narahara começou a freqüentar os cinemas da Liberdade desde muito cedo, por volta dos seis anos de idade, levada pela avó. Em vista do que foi exposto acima, é sintomático o fato de que suas primeiras lembranças dos filmes e dos cinemas apareçam apenas cinco anos depois, a partir do momento em que ela passou a escolhê-los:

[Como se deu o teu primeiro contato com o cinema japonês?]

Vichê! O primeiro contato, acho que eu tinha uns seis anos, cinco, seis, sete anos, acho que foi por aí. Porque eu ia muito com a minha avó, a minha avó é quem me levava. Então é muita influência deles. [Em qual sala de cinema?] Com 5 ou 6 anos eu não me lembro. Eu começo a lembrar dos filmes japoneses quando eu tinha uns 10, 11 anos, por aí, porque até então era a minha avó que me levava, daí não era eu que escolhia o filme, não escolhia nada.

Ao comentar sobre os filmes japoneses que mais lhe marcaram, Ricardo Gonçalves cita a série Miyamoto Musashi (Hiroshi Inagaki, 1954-1956) e o filme Biruma no tategoto (Kon Ichikawa, 1956), exibido no Brasil com o título Não deixarei os mortos. Ele afirma ter passado por uma experiência espiritualizada ao assistir a este filme ${ }^{27}$. Mais do que marcantes, esses filmes levaram Gonçalves a se tornar monge budista. Nessa passagem, é notável a

27 [Talvez o grosso da produção tivesse esse componente de diversão, de passatempo, mas será que eventualmente uma pessoa poderia ter uma experiência de vida ali assistindo?] Sim, uma experiência de encontro ou de reencontro com o Japão perdido, irremediavelmente distante... [Ou alguma experiência espiritualizada?] É, eu mesmo tive essa experiência com aquele filme A Harpa da Birmânia (Biruma no tategoto), que foi uma experiência muito forte para mim, e que, aliás, não tem nada a ver com entretenimento. 
discrepância entre a intensidade da experiência dele com o filme e a absoluta desatenção com que o mesmo foi recebido pelo público e pela crítica na época:

Em grande parte estes filmes me motivaram muito a caminhar em direção ao budismo. E aí tem um outro filme que me marcou muito: A Harpa da Birmânia, Biruma no tategoto, foi um filme que passou no Niterói e que não causou sensação nenhuma aqui, eu me lembro que ficou só uma semana em cartaz e logo tiraram. Eu achei lamentável, um filme bonito, com uma mensagem de paz, de humanidade, de fraternidade entre os povos passar completamente desapercebido aqui.

Um conceito-chave para a antropologia da experiência proposta por Victor Turner é a distinção entre "mera experiência" e "uma experiência", formulada inicialmente por Wilhelm Dilthey:

A mera experiência é, simplesmente, a passiva resignação e aceitação dos eventos. "Uma experiência", como uma pedra num jardim de areia zen, destaca-se da uniformidade da passagem das horas e dos anos [...] Essas experiências que interrompem o comportamento rotinizado e repetitivo - do qual elas irrompem, iniciam-se como choques de dor ou de prazer. Tais choques são evocativos: eles invocam precedentes e semelhanças de um passado consciente ou inconsciente [...] então as emoções de experiências passadas dão cor às imagens e esboços revividos pelo choque com o presente. Em seguida ocorre uma necessidade ansiosa de encontrar significado naquilo que se apresentou de modo desconcertante, seja através da dor ou do prazer, e que converteu a mera experiência em uma experiência. Tudo isso acontece quando tentamos juntar passado e presente (Turner, [1986] 2005: 178-179).

As diversas comparações e metáforas aqui expostas que relacionam as experiências vividas pelos entrevistados no cinema com o ritual, com a religião ou com o sagrado, sugerem não uma relação mecânica do tipo "o cinema é o ritual dos modernos", mas revelam a importância e a dimensão que o ato de ir ao cinema adquiriu na história de vida dessas pessoas. Para Turner, algumas experiências formativas e transformativas são altamente pessoais, enquanto que outras são partilhadas com os grupos aos quais pertencemos por nascimento ou escolha (Turner, ibidem: 179). O sagrado relaciona-se aqui com as experiências tornadas significativas na trajetória dos freqüentadores dos cinemas, a ponto de serem rememoradas com vivacidade décadas depois. A experiência sagrada, intensa ou significativa com o cinema talvez decorra de arranjos originais entre narrativas fílmicas e as histórias de vida dos espectadores. Mas o que lembram as pessoas dos filmes japoneses? É o assunto do próximo capítulo. 
Antecedentes: projeções ambulantes em cidades do interior do estado de São Paulo

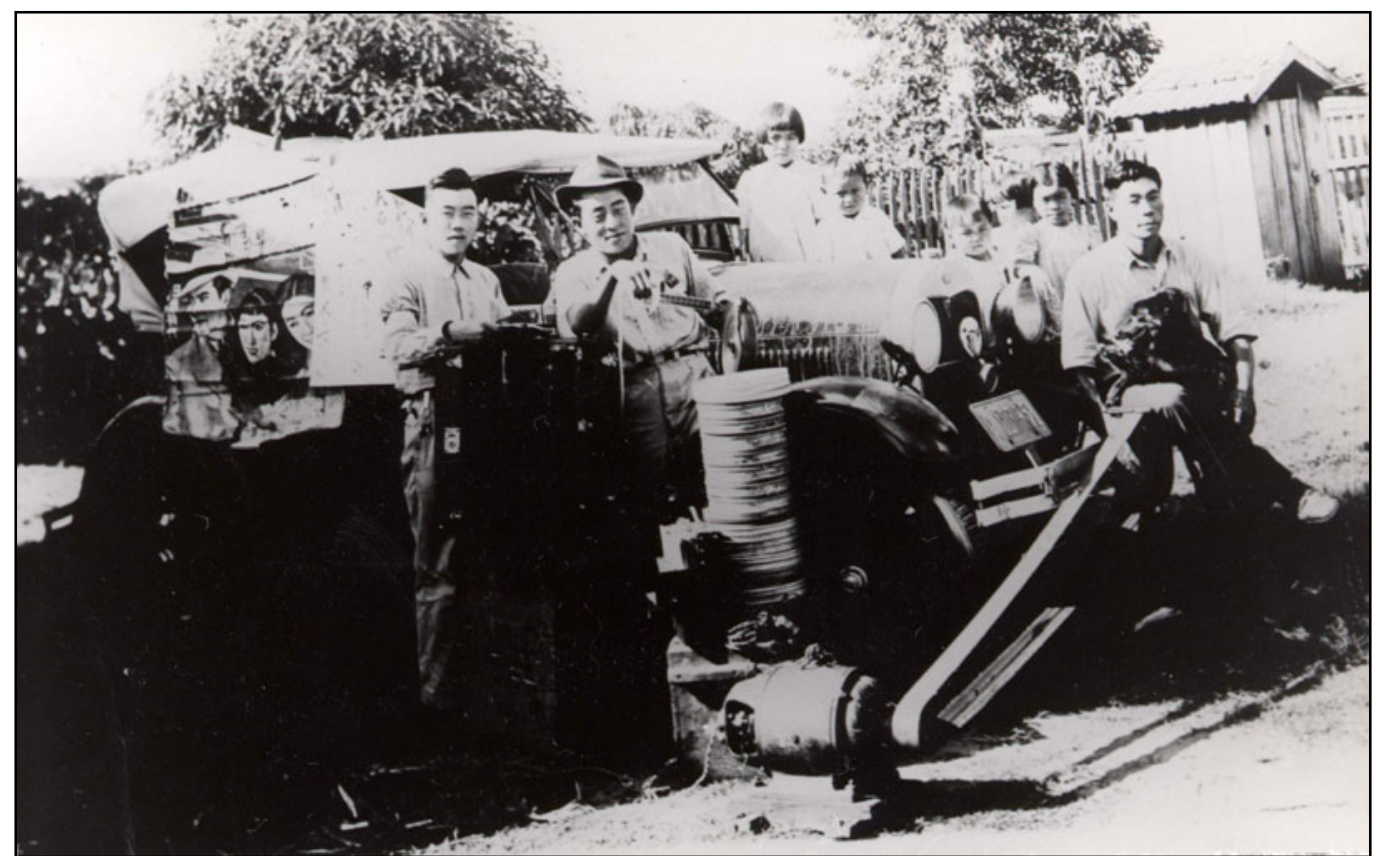

Fig.1: Nas exibições em locais sem rede luz elétrica, para fazer o motor do projetor funcionar, ligava-se ele a um gerador, que por sua vez era acionado pelo movimento da roda do 'pé-de-bode' (automóvel) do projecionista.

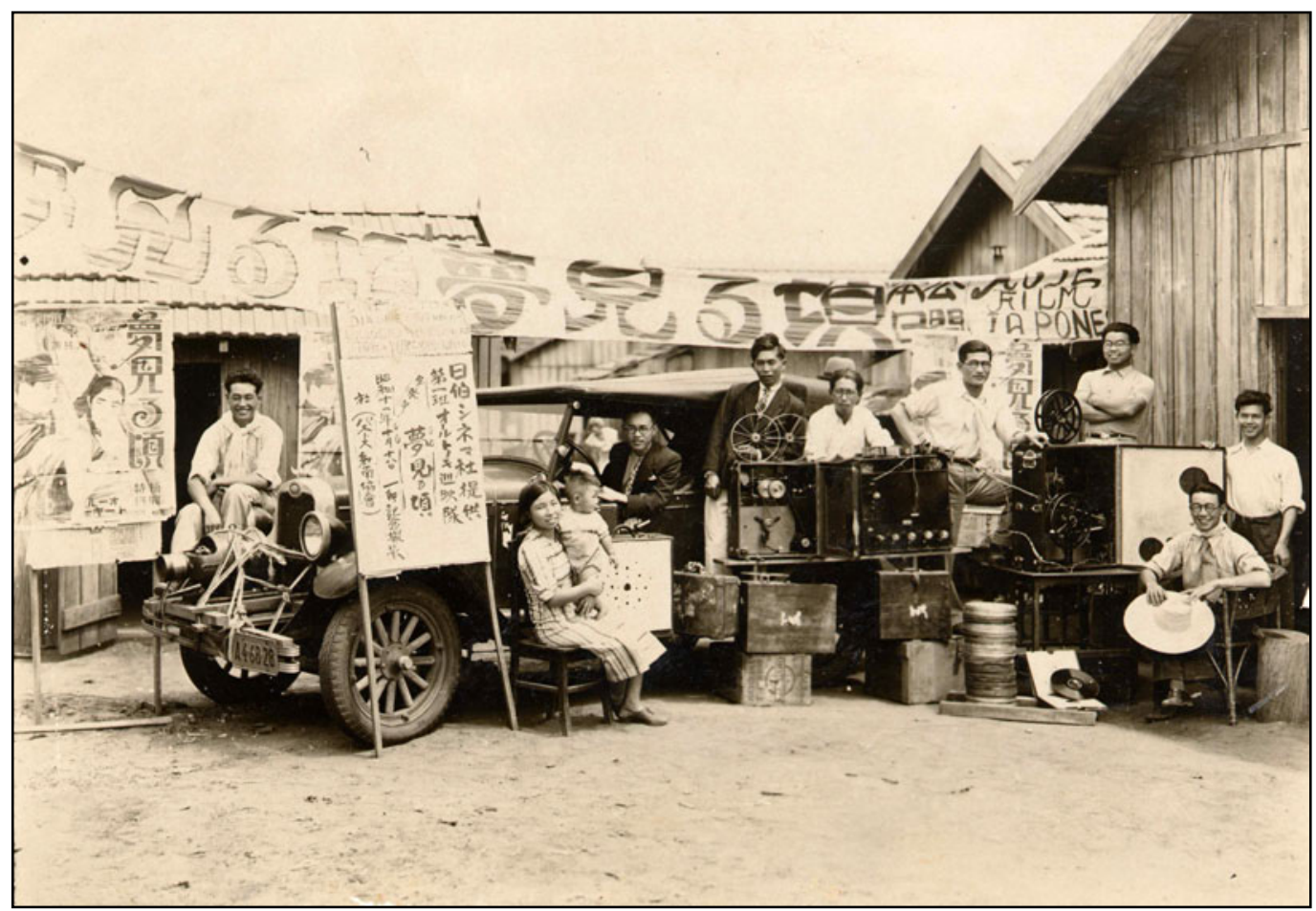

Fig. 2: Acima, sessão de cinema ambulante na cidade de Bastos (SP) em 1936. Dentro do carro, Masaichi Sato, fundador da empresa Nippaku Shinema-sha. Entre os projetores, Kimiyasu Hirata, que fundou outra empresa distribuidora e exibidora de filmes japoneses, a Nippon Eiga Kogyo. 
Antecedentes: sessões de cinema japonês na cidade de São Paulo

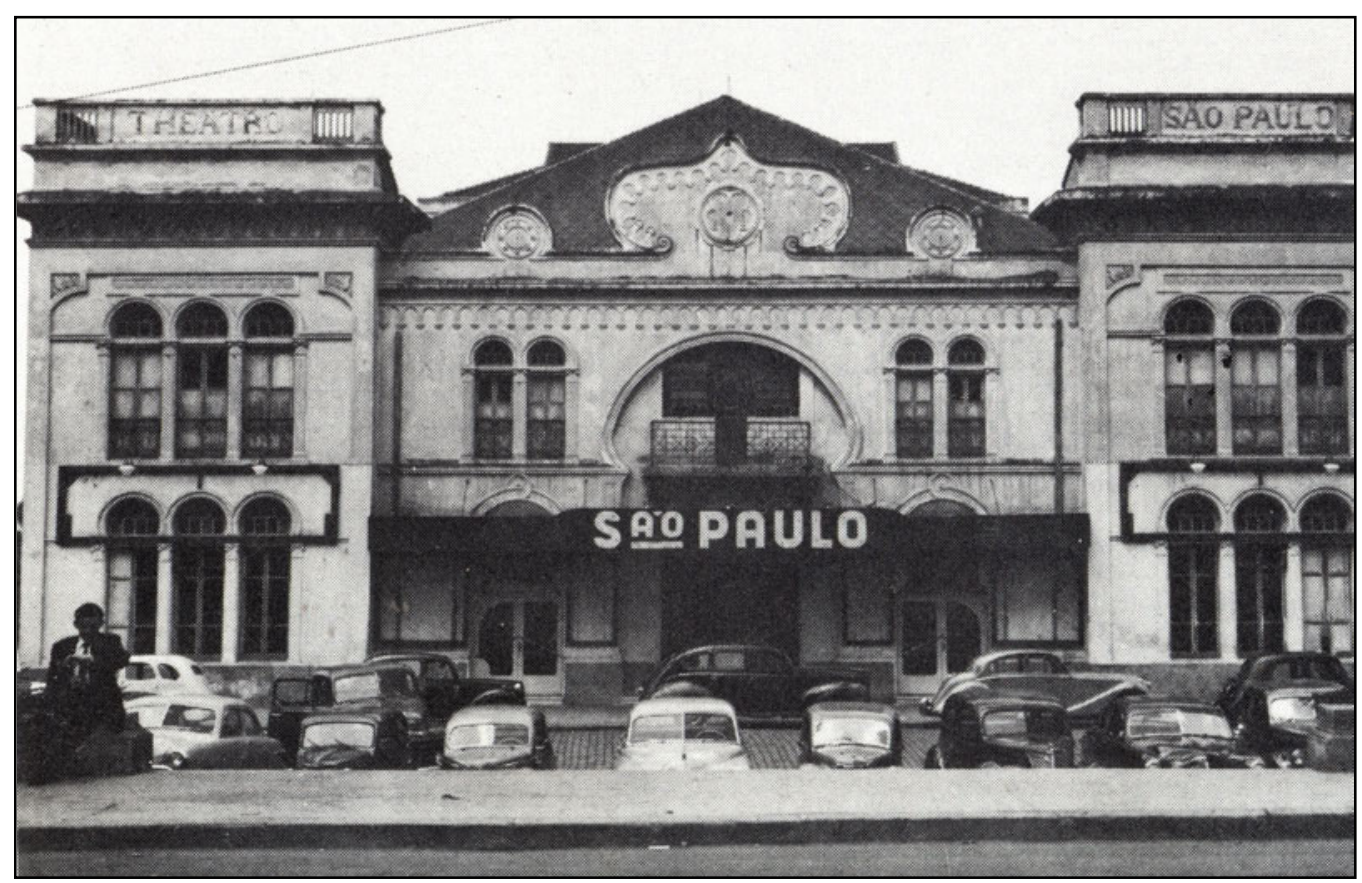

Fig. 3: Cine Theatro São Paulo: inaugurado na praça Almeida Jr. em 1914 e demolido em 1968.

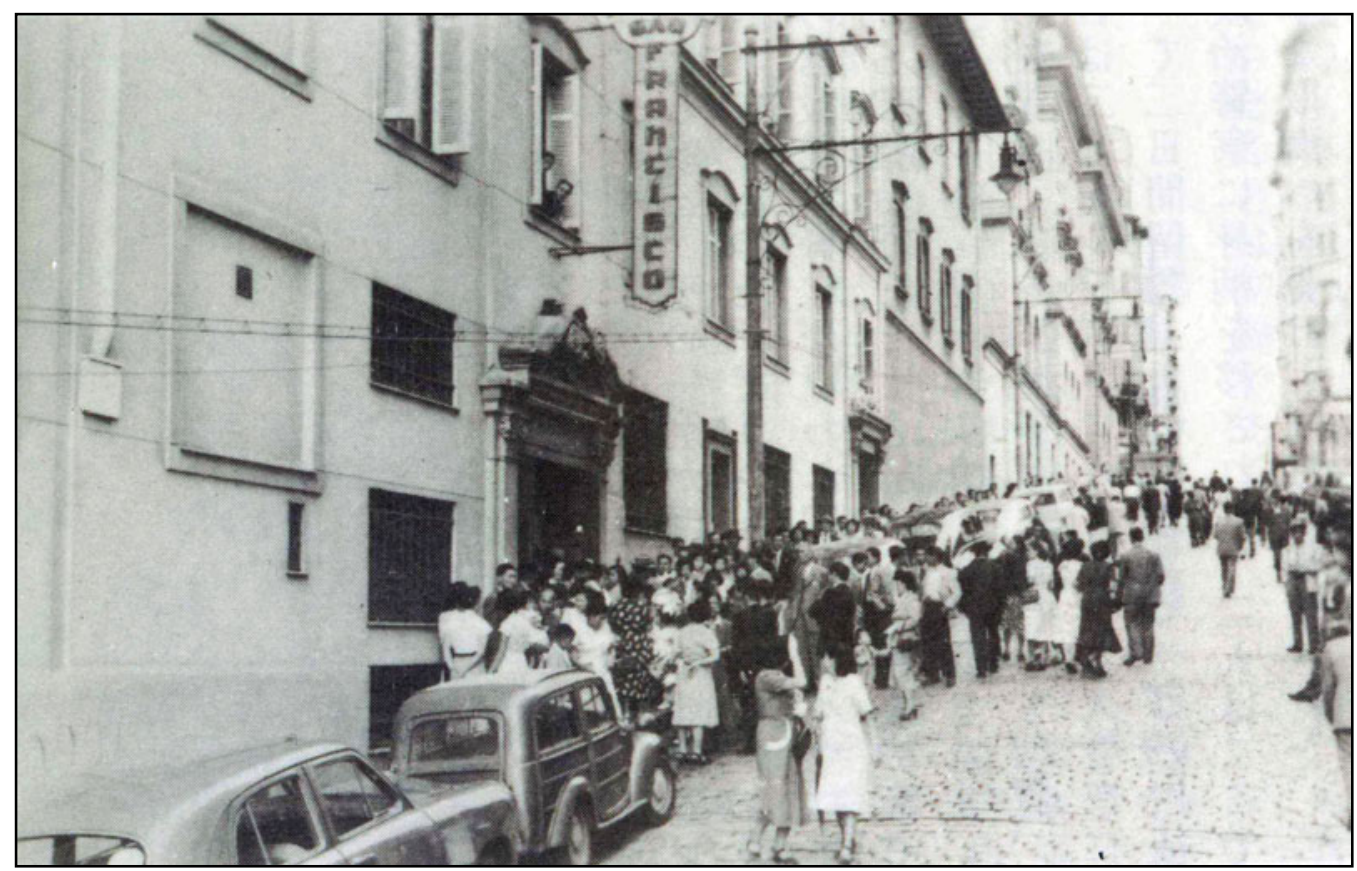

Fig. 4: Cine São Francisco: fundado na década de 1940 e mantido por frades franciscanos na rua Riachuelo, atrás do Largo São Francisco. 
Salas de cinema japonês no bairro da Liberdade

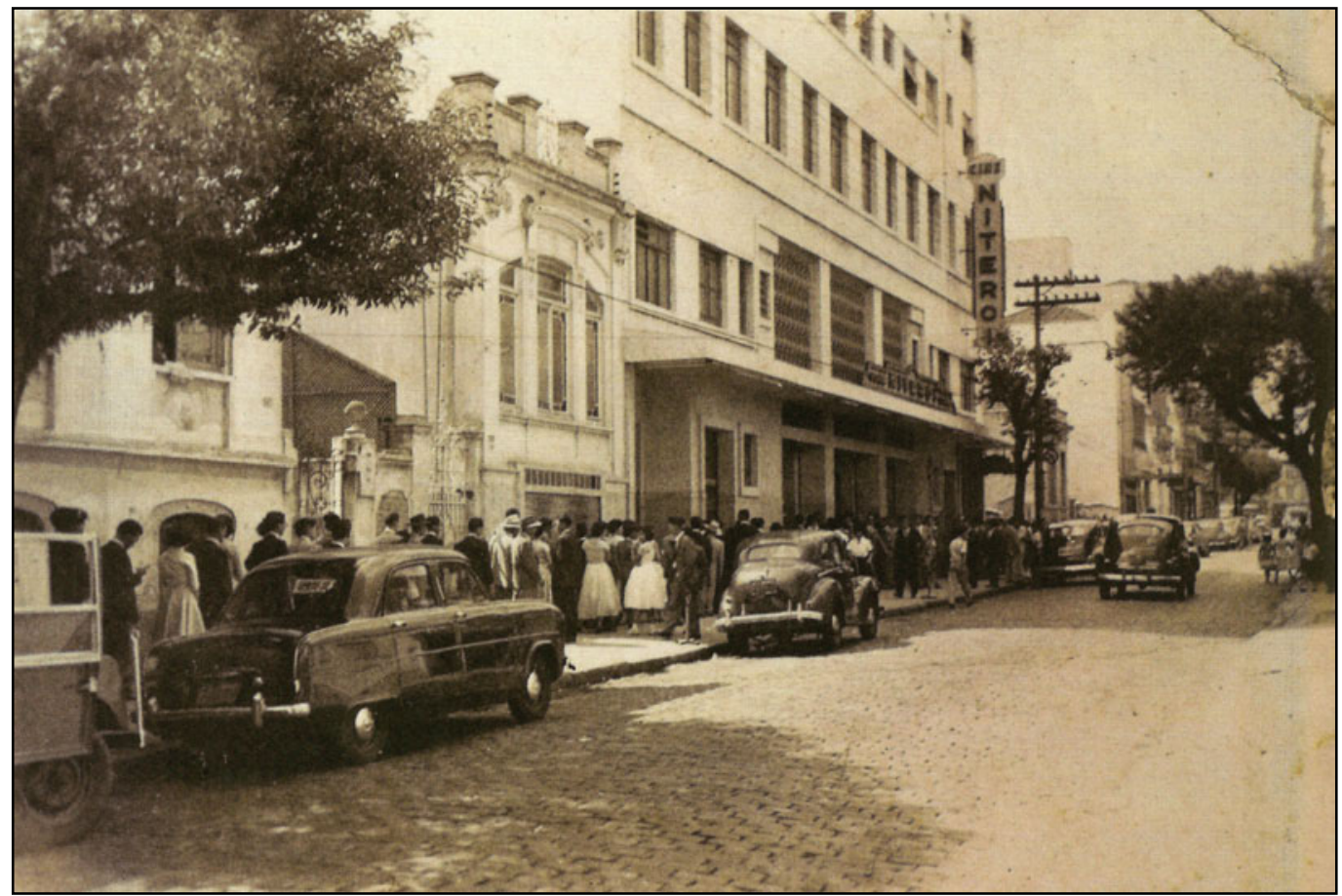

Fig. 5: O primeiro Cine Niterói, localizado na rua Galvão Bueno, 102. O prédio foi inaugurado em 1953 e demolido em 1968, com a construção da Radial Leste-Oeste.

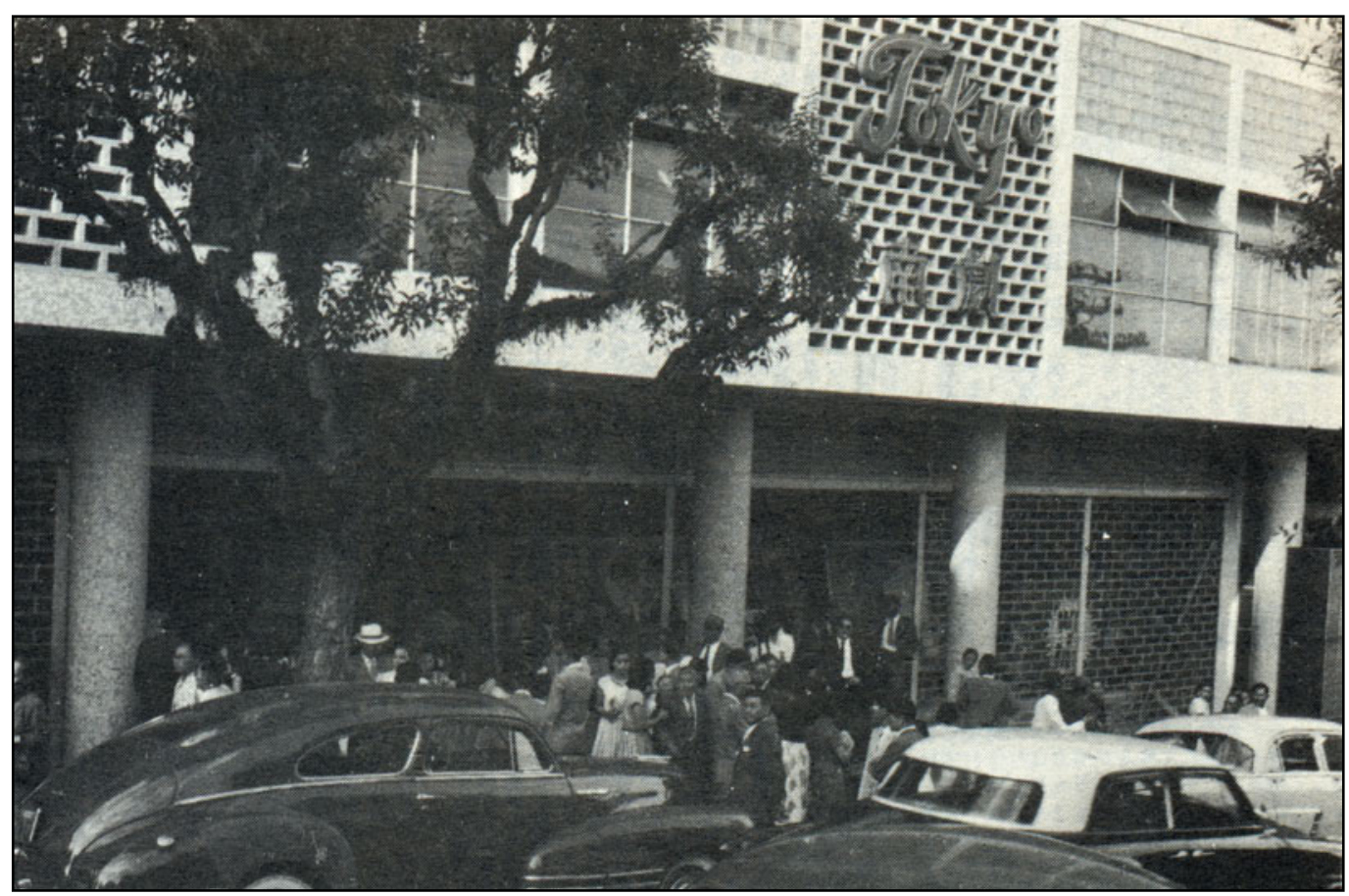

Fig. 6: Cine Tokyo, situado na rua São Joaquim, 129. De 1962 a 1967 passou a se chamar Cine Nikkatsu, exibindo apenas filmes desta companhia cinematográfica. 
Salas de cinema japonês no bairro da Liberdade

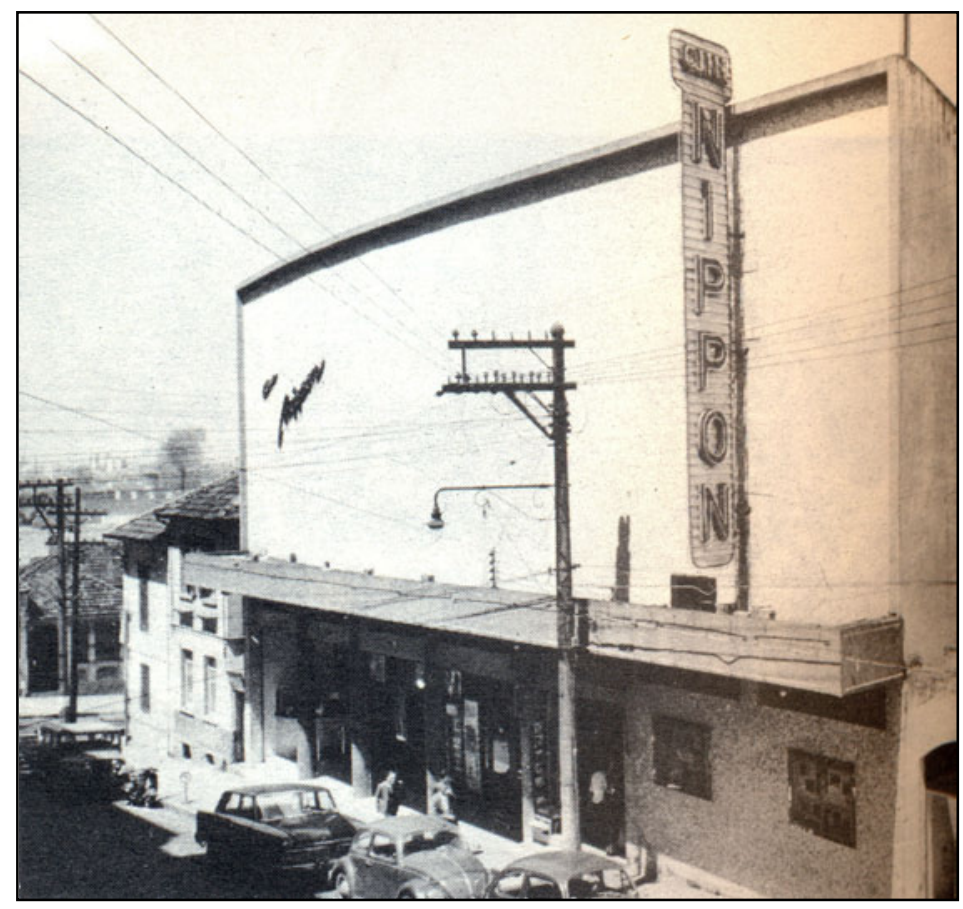

Fig. 7: O Cine Nippon, situado na rua Santa Luzia, 74 (ao lado).

Fig. 10: Na praça Carlos Gomes, 82, localizava-se o Cine Jóia (abaixo).

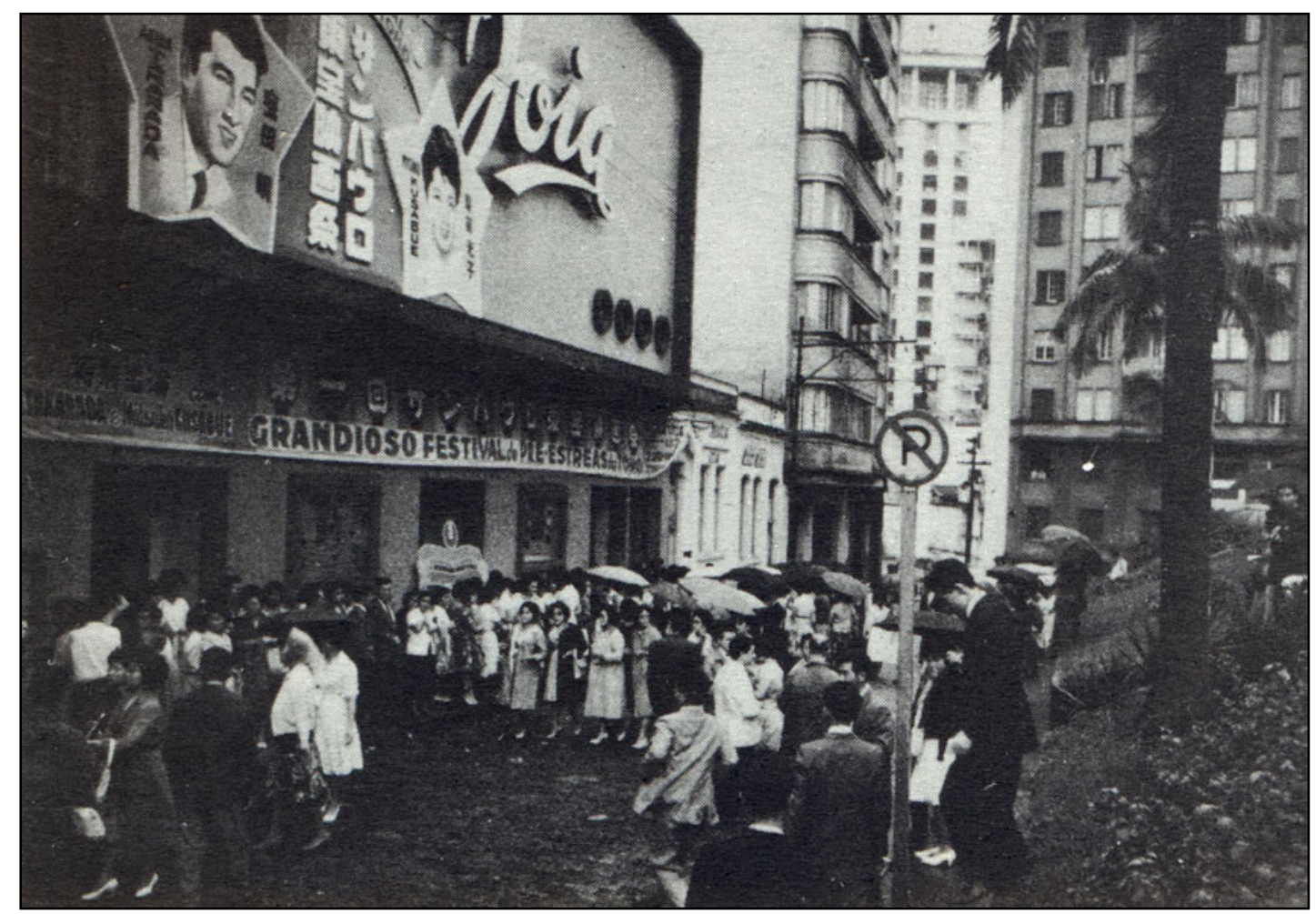




\section{As filas na entrada dos cinemas}

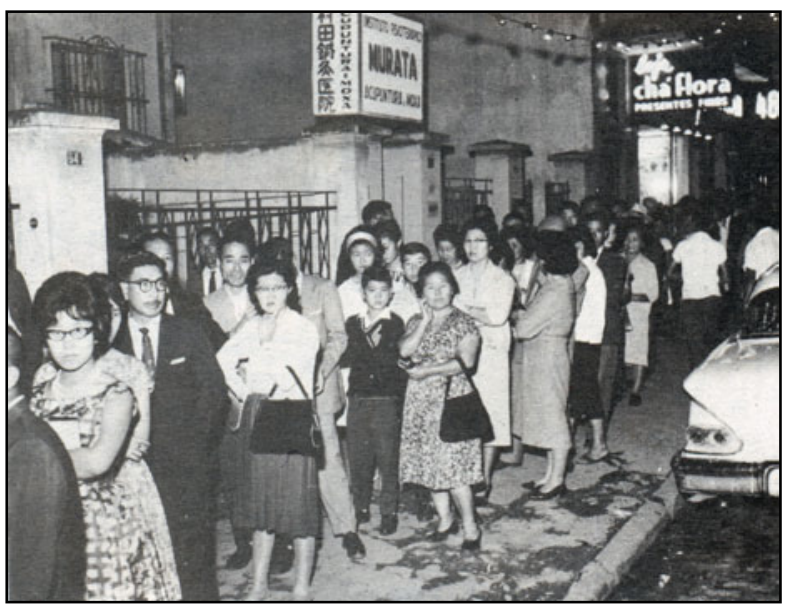

Fig. 16: Cine Brasilândia, fundado em 1953 pelos japonses e nikkeis residentes na região da atual Vila Nova Brasilândia (abaixo).

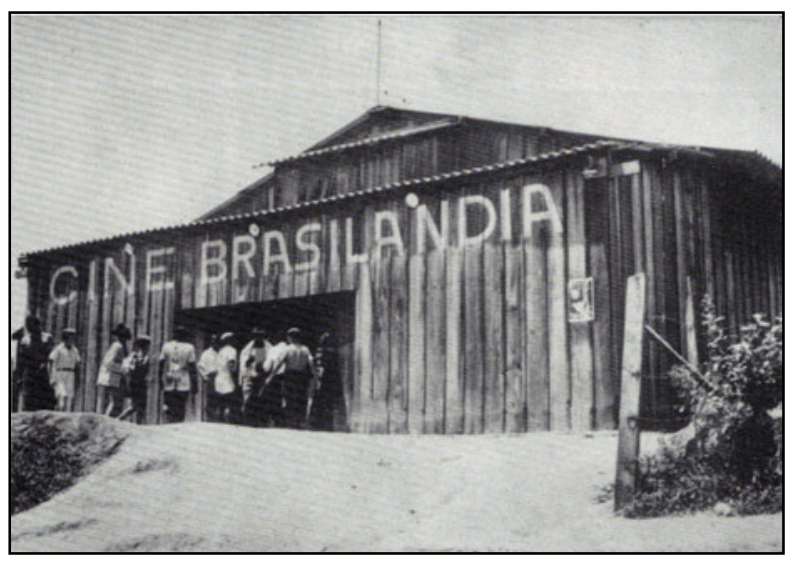

Fig. 13: Fila no quarteirão para entrar no Cine Niterói, em cuja sala cabiam 1500 espectadores (ao lado). Fig. 14: Fila na entrada do Cine Nippon, que exibia os dramas da Shochiku (abaixo).
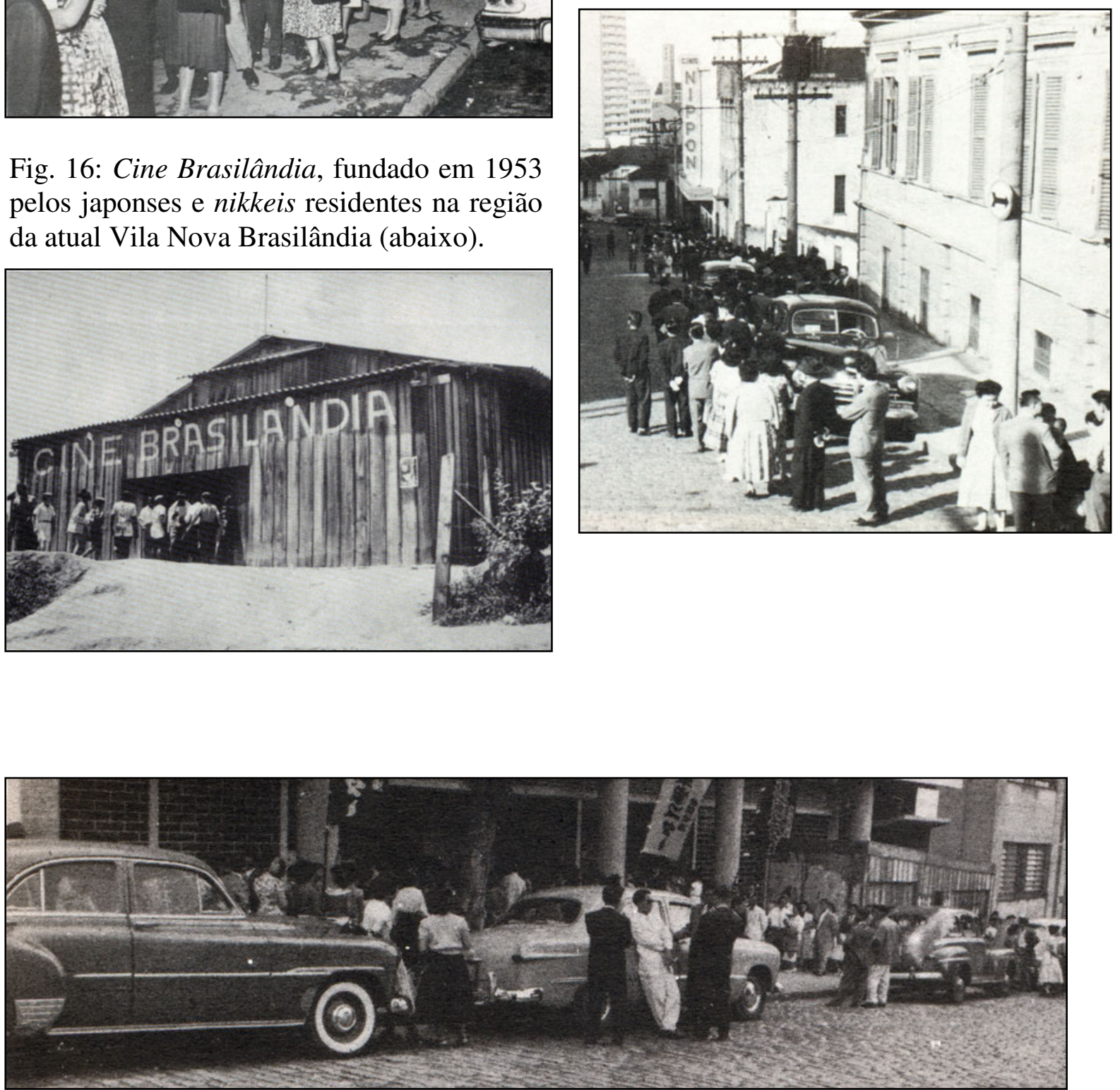

Fig. 15: Detalhe da fila da entrada deste cinema e da situação de paquera descrita nos depoimentos: "E sim, aconteciam paqueras, às vezes os rapazes ficavam do outro lado da calçada, ou encostado em um carro, ou em um bar na esquina, só 'bisoiando' e as mocinhas na fila com as suas famílias...era muito divertido" (Olga Futemma). 


\section{Experiências dos entrevistados com atores e atrizes japoneses}
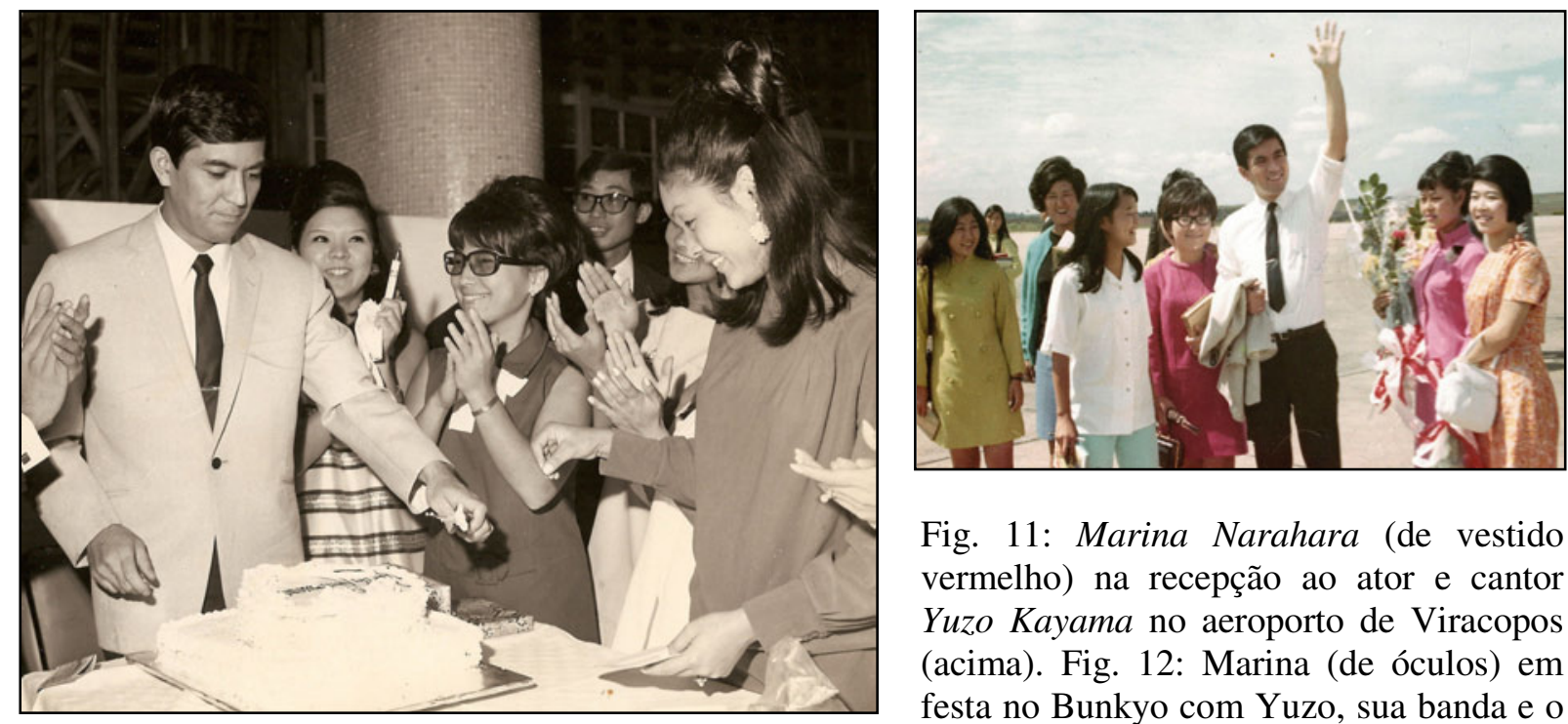

Fig. 11: Marina Narahara (de vestido vermelho) na recepção ao ator e cantor Yuzo Kayama no aeroporto de Viracopos (acima). Fig. 12: Marina (de óculos) em festa no Bunkyo com Yuzo, sua banda e o pessoal do grêmio (ao lado).

Fig. 8: Alfredo Sternheim entrevista Miyuki Kuwano no aeroporto de Congonhas, em 1966 (ao lado). Fig. 9: Sternheim, Astolfo Araújo, Kuwano, José Luiz e Rubem Biáfora na recepção à atriz (abaixo).
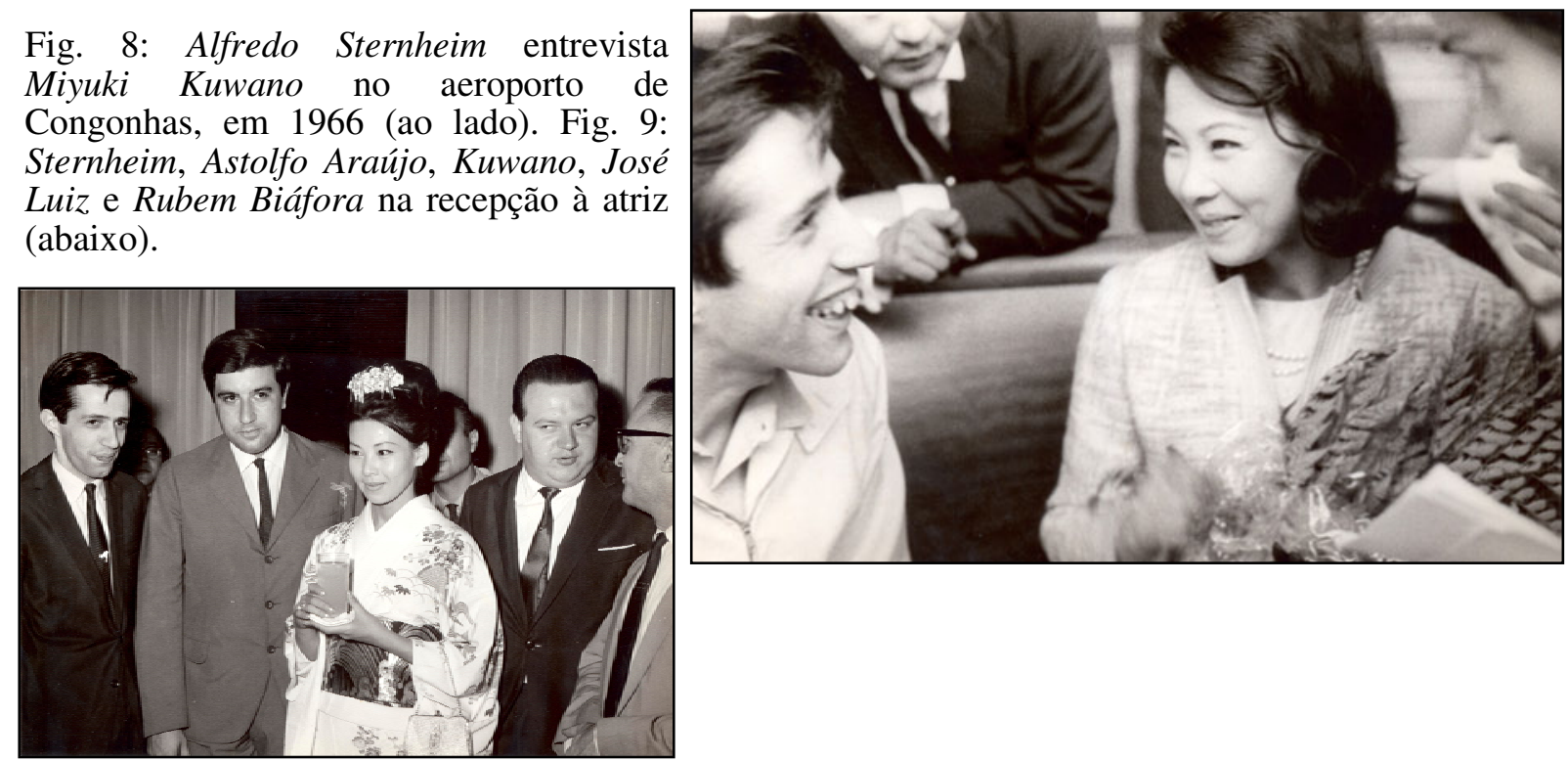


\section{Filmes japoneses em São Paulo}

\subsection{São Paulo, Estados Unidos e Japão: montagem paralela}

Das primeiras projeções ambulantes de filmes japoneses ao fechamento do último cinema da Liberdade, em 1988, quantos filmes japoneses foram exibidos em São Paulo? Como visto no capítulo anterior, de 1926 até o início da Segunda Guerra Mundial, o estado de São Paulo assistiu ao desenvolvimento de um complexo circuito de exibições ambulantes de cinema japonês destinado ao público residente em cidades do interior e em bairros da capital com concentração de nikkeis. Esse circuito era mantido por agentes individuais e por pequenas empresas de distribuição e exibição de filmes. Desconhece-se a existência de registros sistemáticos dos filmes japoneses importados e exibidos nessa época. Outra dificuldade resulta do fato narrado por Kimiyasu Hirata, um dos pioneiros na exibição de filmes japoneses no país, de que grande parte dos filmes apresentados no período anterior à guerra, e mesmo depois dela, teria sido recomprada de uma empresa norte-americana de distribuição de filmes japoneses, razão que explicaria a inexistência de registros de exportação de filmes diretamente do Japão ao Brasil na época.

Ainda se restringíssemos a pergunta apenas aos filmes exibidos nos cinemas da Liberdade, isto é, ao período compreendido entre 1948 e 1988, a leitura de estudos anteriores parece indicar a impossibilidade de se determinar sua quantidade com precisão. Ao reexaminar uma tabela de importação de filmes japoneses de 1939 a $1978^{28}$, André Gatti conclui de maneira vaga: "Os números são impressionantes, pois como a tabela apresenta algumas lacunas periódicas importantes, pode-se deduzir que o número de filmes exibidos superou em muito a casa de mil unidades" (Gatti, 2008: 36). Para José Fioroni Rodrigues (1995), só na "fase de ouro" do cinema japonês em São Paulo, isto é, de 1959 a 1967, período em que a cidade contou com os quatro cinemas da Liberdade em funcionamento, foram exibidos cerca de 1.200 filmes japoneses.

Num texto publicado em japonês no livro Coronia Gueinoshi (1986), Tsuyoshi Mizumoto, presidente da Shochiku do Brasil, calculou que em seus vinte anos de atividade (1961-1981), a empresa teria importado 732 filmes, sendo 672 "novos". Na mesma publicação, Massao Oshida, representante da Toho Filmes América do Sul (Nambei Toho), afirmou que esta teria importado 722 filmes até o final de 1978, ano em que encerrou suas atividades no Brasil. Ou seja, 1.454 filmes japoneses teriam sido importados por apenas duas

\footnotetext{
${ }^{28}$ Esta tabela foi formulada por ele mesmo trinta anos antes e publicada na revista Cinema em close-up de abril de 1978 (Gatti, 2008: 35-36).
} 
das quatro companhias cinematográficas japonesas que contavam com escritórios próprios e salas de cinema exclusivas em São Paulo. Diante desses dados, a tabela apresentada por Patrícia Moribe (1991) com informações fornecidas por José Fioroni Rodrigues parece ser a mais completa, indicando em 2.620 o número de lançamentos de filmes japoneses na cidade, de 1948 a $1988^{29}$.

Rodrigues (1995) observa que na década de 1950 a média anual de lançamentos de filmes japoneses em São Paulo era de 35 títulos. Em relação ao conjunto da atividade de exibição cinematográfica da cidade, o que isso representava? Em 1952 foram exibidos trinta filmes japoneses, quantidade que representaria menos de $10 \%$ do total de filmes norteamericanos lançados naquele ano (314 títulos) ${ }^{30}$. No entanto, este volume já colocaria o Japão em quinto lugar, empatado com o México, entre os países com maior número de filmes apresentados no Brasil ${ }^{31}$. Com a abertura do escritório da Toho em São Paulo, a importação de filmes duplicou: 78 filmes japoneses foram exibidos em 1958. De 1960 a 1973 foram lançados anualmente mais de cem filmes, tendo o pico ocorrido em 1963, ano em que 166 filmes japoneses foram exibidos na capital paulista.

No Japão, em meados da década de 1950, o cinema de gênero produzido pelas seis grandes companhias cinematográficas (Shochiku, Toho, Shintoho, Daiei, Nikkatsu e Toei) faria deste país o maior produtor de filmes do mundo, lançando, a partir daí, mais de quinhentos filmes por ano (Nagib, 2005). Em 1959, o número de cinemas do país teria triplicado em relação ao do período anterior à guerra, chegando a 7.401 salas exibidoras. $\mathrm{O}$

\footnotetext{
${ }^{29}$ Freqüentador assíduo das sessões de cinema japonês desde 1949, José Fioroni Rodrigues teria assistido a cerca de 2.300 a 2.400 filmes desse total (Moribe: 1991). O que justificaria o valor atribuído à tabela apresentada por Moribe é a autoridade publicamente reconhecida da fonte: Rodrigues é citado por muitos dos que concederam depoimentos ao autor como a "memória viva" do cinema japonês em São Paulo. Infelizmente, meu único contato com ele aconteceu por meio de uma breve conversa telefônica, uma vez que ele se recusou a conceder entrevista para esta pesquisa. Trabalhos anteriores, no entanto, chamam a atenção para a riqueza de seu arquivo pessoal sobre o cinema japonês, bem como para seus cadernos e listas, nos quais ele teria catalogado sistematicamente todos os filmes assistidos (Moribe, ibidem; Kobayashi, 2005).

${ }^{30}$ Os dados sobre os filmes japoneses são da tabela apresentada por Patrícia Moribe (1991) com informações de José Fioroni Rodrigues. Os dados sobre os lançamentos de outras cinematografias nacionais são da tabela “Origem dos Filmes Lançados no Brasil de 1941 a 1952", formulada por Randal Johnson (1987) e reproduzida por Heloísa Buarque de Almeida (1995: 131).

${ }^{31}$ Curiosamente, a tabela apresentada por Randal Johnson, que apresenta onze diferentes países como origem dos filmes lançados no Brasil, omite qualquer menção aos filmes japoneses. Estariam os trinta filmes japoneses incluídos na categoria de Outros (41 títulos)? E por que estariam, se, por exemplo, a cinematografia russa só teria apresentado 18 filmes nos dez anos analisados? Em todo caso, do cruzamento de dados das tabelas citadas conclui-se que em 1952 a cinematografia japonesa apareceria em quinto lugar em termos da quantidade de filmes lançados no Brasil, atrás da norte-americana (314), da italiana (46), da francesa (53), da brasileira (34) e empatada com a mexicana (30); o que não é pouco, considerando o sucesso dos filmes mexicanos na época, como A Pecadora (1947), que permaneceu vinte semanas em cartaz e arrecadou mais do que Escola de Sereias (1944), exibido durante três meses no Cine Metro (Simões, 1986: 62).
} 
pico da produção cinematográfica japonesa seria atingido em 1960, com os 547 filmes produzidos naquele ano (McDonald, 1990).

Lúcia Nagib (1993) estabelece um paralelo entre o sistema de estúdio (studio system) japonês e o sistema praticado pelas cinco majors companies norte-americanas: ambos teriam sido estruturados sobre o cinema de gênero, a produção de filmes em série, orientada por intenções comerciais e segundo fórmulas de sucesso: enquanto nos Estados Unidos se produziam westerns, pastelões, filmes de guerra, entre outros, no Japão eram realizados dramas de época (jidaigeiki), dramas contemporâneos (gendaigeki), filmes de yakuza, etc.

Outra semelhança entre o sistema de estúdio norte-americano e o japonês reside no que Thomas Schatz ([1988] 1991) define como "sistema integrado de produção", isto é, o controle das etapas de produção, distribuição e exibição das obras cinematográficas, observável em ambos os casos:

A Metro Goldwin Mayer e a Warner eram as "grandes integradas", bem como a 20th Century Fox, a Paramount e a RKO. Esses cinco estúdios criaram suas próprias cadeias de salas exibidoras e dominaram o mercado cinematográfico de primeira linha - os palácios e salas de luxo do centro das grandes cidades, de onde provinha a maior parte da renda de bilheteria (Schatz, 1991: 25).

A ausência de leis antitruste na indústria cinematográfica [japonesa] tornou mais fácil para as companhias cinematográficas majoritárias [majors film companies] o controle da distribuição. Toei, Nikkatsu, Toho e Shochiku todas têm cinemas sob o seu controle direto, além de outros sob contratos especiais (McDonald, 1990: 46) [tradução do autor].

A menção à ausência de leis antitruste no Japão é significativa: o primeiro trecho faz referência ao controle exercido pelas majors companies sobre as salas exibidoras dos Estados Unidos. Esta situação passou por uma transformação drástica no pós-guerra, a partir da adoção de medidas antitruste pelo governo norte-americano, que promoveram o "divórcio" das cadeias de cinema das grandes companhias (Schatz, 1991: 303); já o texto de Keiko McDonald refere-se à situação do mercado cinematográfico japonês no final da década de 1980, época em que a Toho controlava ainda 531 salas de cinema no Japão, situação análoga ao controle exercido pelas mesmas companhias sobre as salas de cinema no auge do sistema de estúdio, trinta anos antes.

Estes dois fragmentos, no entanto, não se remetem apenas aos mercados cinematográficos dos Estados Unidos e do Japão entre as décadas de 1930 e 1980. Eles se relacionam também com o contexto cinematográfico paulistano de meados do século XX: as mesmas companhias japonesas citadas por McDonald abriram empresas de distribuição em São Paulo e mantiveram as salas de exibição da Liberdade sob contratos especiais, 
transformando-as em cinemas exclusivos; na época em que o cinema se consolidou como a diversão mais popular dos paulistanos, entre as décadas de 1940 e 1950, as produções das companhias norte-americanas representaram três quartos do total de filmes lançados nos cinemas da cidade (Johnson apud Almeida, 1991). Notável também é a semelhança entre a relação da Metro Goldwin Mayer com as salas exibidoras norte-americanas, na época do sistema de estúdio, e a que se estabeleceu entre esta mesma empresa com o Cine Metro e o Cine Itapura na cidade de São Paulo, conforme observado por Heloísa Buarque de Almeida:

Como a Cinelândia reunia as melhores salas, eram estas as lançadoras, ou seja, os filmes eram exibidos primeiro ali a um preço mais elevado. Depois de algum tempo, às vezes algumas semanas, às vezes um ou dois meses, os mesmos filmes chegavam às salas mais baratas, como as outras do centro e as de bairro. Os filmes exclusivos do Cine Metro, por exemplo, só seriam exibidos em outra sala 60 dias depois de sua estréia ali. [...] Havia também os cinemas que eram "exclusivos" como o Cine Itapura, na Aclimação. Assim como o Metro, o Itapura só exibia filmes da Metro Goldwin Mayer, mas somente depois do Cine Metro e a um preço menor (Almeida, 1995: 49-50) ${ }^{32}$.

A despeito das aparentes semelhanças entre os sistemas de estúdio japonês e norteamericano, Nagib (1993) enfatiza dois pontos de diferenciação: o primeiro é a relativa pobreza e a austeridade econômica dos "grandes" estúdios japoneses, se comparado aos recursos milionários empregados nas superproduções das companhias norte-americanas. Os salários irrisórios pagos aos funcionários, os cenários precários que se repetiam filme a filme e os figurinos uniformizados presentes nas produções japonesas são contrastados pela autora aos cenários monumentais, figurinos luxuosos e elencos e equipes numerosos e bem pagos correntes nos filmes de Hollywood.

O segundo ponto, - e o que mais nos interessa aqui - é a diferenciação quanto à orientação da produção das indústrias cinematográficas norte-americanas e japonesas:

\footnotetext{
${ }^{32}$ Inimá Simões atenta para o fato de que a concepção norte-americana de circuito teria vingado em boa parte do mundo, conformando um padrão arquitetônico comum para as salas de cinema, como um efeito da formação de um mercado internacional para os filmes das companhias norte-americanas: "Não é de se espantar, visto de hoje, que o Cine Metro paulistano, inaugurado em 1938, tivesse 'as mesmas características daqueles da Broadway ou da Champs Elisées', como comenta um embasbacado cronista da época. Ele não sabia, mas o nosso Metro era igualmente parecido com os de Bogotá e Cidade do México, sem contar o de Havana" (Simões, 1990: 10). Citando Simões, Heloísa Buarque de Almeida afirma, no entanto, que a relação do Cine Metro com a Metro Goldwin Mayer (MGM) foi uma exceção na Cinelândia Paulista, não a regra: "Excetuando-se este caso, as salas costumavam fazer um rodízio de filmes dos diferentes estúdios. O Ipiranga, por exemplo, em meados dos anos 40, exibia por duas semanas um filme de cada estúdio na seguinte ordem: Fox, Warner, Paramount, Universal e RKO, voltando depois a outro filme da Fox" (Almeida, 1995: 50). Disto decorre a seguinte reflexão: de que a identidade observada entre as salas de cinemas da Liberdade com os gêneros cinematográficos produzidos pelas companhias das quais eram exibidoras exclusivas, só encontra paralelo, na cidade de São Paulo, no caso dos cines Metro e Itapura com os filmes da MGM.
} 
Nos Estados Unidos, o cinema sempre teve uma orientação industrial decididamente voltada para o mercado internacional. No Japão, se o cinema conseguiu em alguns momentos penetrar os países vizinhos da Ásia ou mesmo as colônias japonesas no exterior [como a do Brasil], sua principal meta era o mercado interno. Tratava-se de um cinema autocentrado, dirigido basicamente para públicos japoneses, mesmo quando, em meados da década de 1950, alcançou a cifra admirável de mais de 500 filmes ao ano [...] (Nagib, 1993: 20).

Como entender essa "época de ouro" do cinema japonês de meados dos anos 1950, que conseguiu conciliar prosperidade comercial com o reconhecimento internacional de sua excelência artística? Dez anos apenas se passaram desde o fim da Segunda Guerra Mundial, da qual os Estados Unidos saíram economicamente fortalecidos e o Japão, arruinado. Considerando a discrepância dos recursos empregados na produção de filmes nos dois países, e, ainda, o contraste entre a hegemonia exercida pelo cinema norte-americano nos mercados internacionais e o direcionamento dos filmes japoneses para o seu mercado interno, como compreender que o cinema japonês tenha ultrapassado o norte-americano na produção anual de filmes? Qual a implicação do Brasil abrigar a maior das colônias japonesas no exterior no tocante ao acesso à filmografia japonesa? Isto é, considerando a expressiva presença dos nikkeis na capital paulista, qual teria sido a especificidade do mercado cinematográfico de São Paulo em relação aos das outras metrópoles ocidentais?

De acordo com Keiko McDonald (1990), o retorno à independência nacional com a assinatura do Tratado de Paz de São Francisco, em 1951, teve um efeito direto nos aspectos comerciais e artísticos do cinema japonês. Os filmes de época (jidaigeki), especialmente os filmes de lutas de espada (chanbara), que haviam sido quase totalmente banidos durante o governo de ocupação norte-americana, voltariam a cativar sua saudosa audiência.

A Toei, companhia cinematográfica criada em 1951, tomou a dianteira com algumas significativas inovações: em primeiro lugar, adaptou o gênero jidaigeki ao vasto e novo mercado das crianças e dos adolescentes. A lembrança de Olga Futemma acerca do primeiro filme assistido na vida, um filme de samurai com censura de dez anos, bem como a de Jo Takahashi, que aos sete ou oito anos assistiu ao filme Akai kage-bôshi (Sombra vermelha, 1962), ambos no Cine Niterói, relacionam-se com esse novo foco adotado pela companhia.

Em 1954, a Toei experimentou outra estratégia de mercado: a exibição de dois longametragens de ficção numa mesma sessão (double featuring ou double bill), o que provocaria uma contínua pressão por produção, não apenas para este estúdio como para todos os demais $^{33}$. Em 1958, por exemplo, criou-se uma subdivisão da companhia, a Daini-Toei,

\footnotetext{
33 A data apontada por McDonald relacionada à adoção da sessão dupla (double featuring) converge com a afirmação de José Eduardo Marques de Oliveira, crítico de cinema integrante do pioneiro Grupo de Estudos
} 
encarregada da produção em massa de filmes, especialmente os de chanbara. O patamar de produção de quinhentos filmes por ano teria sido atingido pelas companhias cinematográficas japonesas em meio a estas decisões comerciais.

Para McDonald, a adoção dessas estratégias teria provocado uma reação em cadeia nos estúdios rivais, resultando numa divisão de mercado: a Shochiku continuou a enfatizar o melodrama, especialmente o shomingeki (drama da classe-média baixa), ao gosto do público feminino; a Toho cativou o "mercado do colarinho branco", com séries de comédias sobre o shasho, o presidente da empresa; a Daiei foi bem-sucedida na produção de filmes de arte, vencedores de festivais internacionais, como Rashomon de Akira Kurosawa e Contos da lua vaga depois da chuva, de Kenji Mizoguchi; a prosperidade da Nikkatsu dependeu de seus taiyozoku eiga (filmes sobre a geração do sol) ${ }^{34}$, com forte apelo ao público juvenil; a ShinToho trabalhou temas militaristas sob um viés ultraconservador (McDonald, 1990: 36).

Parece haver uma correspondência entre essa divisão do mercado japonês por meio da especialização dos estúdios em gêneros específicos e as caracterizações dos cinemas da Liberdade a partir dos gêneros de filmes mais exibidos, descritas no capítulo anterior. Augusto Tanaka, filho de Yoshikazu, o fundador do Cine Niterói, foi o último gerente deste cinema. Num depoimento, ele afirma que praticamente não havia concorrência entre as salas porque cada uma delas era especializada em tipos diferentes de filmes (Kobayashi, 2005: 28).

\subsection{Séries de filmes e versões de uma mesma história}

A produção de filmes em série expressava-se também nos filmes apresentados em episódios, isto é, as séries de filmes, que perpassavam quase todos os gêneros cinematográficos: entre os filmes de época (jidaigeki), particularmente entre os de luta de espadas (chanbara), são citadas por alguns dos antigos freqüentadores dos cinemas da Liberdade: Kurama Tengu, série de cinqüenta filmes produzidos de 1924 a 1959 sobre o personagem das novelas escritas por Osaragi Jirô, que obtiveram grande sucesso junto ao público japonês; Miyamoto Musashi série de cinco episódios dirigidos por Tomu Uchida entre

Fílmicos, no livro O Cinema Japonês: "O Japão passa a ser o primeiro produtor mundial de filmes em 1954" (Ohno, 1964: 73).

${ }^{34}$ Taiyozoku eiga (filmes sobre a "geração" ou a "tribo" do sol), comentados na página 12, é uma série de filmes realizados principalmente na Nikkatsu, baseados em romances do escritor Shintaro Ishihara. Maria Roberta Novielli caracteriza assim a obra do escritor: "Ishihara, depois roteirista e diretor, além de escritor, ganhara o prêmio Akutagawa com seu romance Estação do sol (Taiyo no kisetsu, 1955), revolucionando o panorama literário com a proposta de um "teorema", segundo o qual, terminado definitivamente o pós-guerra, nada restava às novas gerações, a não ser rejeitar firmemente todo o tipo de moral advinda dos seus pais. No lugar das velhas virtudes, os "novos" jovens irrequietos viviam imersos em situações extremas, como o sexo (não amor, apenas o ato físico) e a violência" (Novielli, 2007: 163). 
1961 e 1965, a partir do romance épico de Eiji Yoshikawa, uma das obras literárias mais vendidas na história editorial do Japão; e Zatoichi, série de 26 filmes sobre o espadachim cego, produzidos entre 1962 a 1989 e protagonizados pelo ator Shintaro Katsu ${ }^{35}$.

Entre os dramas contemporâneos (gendaigeki), é citada por Eunice Yokota e Fioroni Rodrigues uma série importada pela Nippon Cinema-sha de Kimiyasu Hirata, que teria feito grande sucesso na época: o melodrama $A$ mãe $(H a h a, 1948)$ e as suas dez seqüências exibidas em São Paulo, comparadas por Yokota a uma novela; Ricardo Gonçalves lembra das comédias dirigidas por Shuhei Matsubayashi sobre o presidente da empresa, o shasho mono, série de trinta filmes que teriam sido produzidos até o esgotamento do gênero; entre os filmes de monstros (kaiju eiga), Gonçalves lembra que traduziu o primeiro Godzilla [Gojira] (1954, Ishiro Honda), cujo sucesso originaria uma série de sete outros filmes realizados pela Toho de 1955 a 1970, além de outras séries de filmes com novas criaturas (Novielli, 2007: 161).

Em relação aos filmes destinados ao público jovem e protagonizados por atorescantores, além dos já citados nove episódios da série Ave migratória (Watari Dori) e dos cinco de Vagabundo (Wagaremono), interpretados por Yujiro Ishihara, a série de quatro filmes produzidos pela Toho, de 1955 a 1964, com as estrelas da música Misora Hibari, Eri Chiemi e Yukimura Izumi, é mencionada por Marina Narahara e Eunice Yokota (Fig. 17).

O ator-cantor Kayama Yuzo veio ao Brasil em abril de 1968 para a comemoração do décimo aniversário da Toho no país. Como referido no capítulo 1, Narahara foi ao aeroporto recebê-lo e participou de uma festa em sua homenagem no Bunkyo. Yuzo e sua banda apresentaram o "Golden Show" no Cine Jóia, em Mogi das Cruzes (SP) e em Londrina (PR), seguindo depois ao Rio de Janeiro para as gravações do filme Rio no Wakadaishô (1968), um dos vinte filmes da série produzida entre 1961 e 1981 (Sociedade Brasileira de Cultura Japonesa, 1986). Ricardo Gonçalves rememora a sua participação na realização do filme:

Tinha um outro ator também que eu conheci pessoalmente, o Kayama Yuzo. Ele esteve no Brasil e eu tenho uma história sobre isto. Ele fazia uma série de comédias românticas para juventude, a série Wakadaishô, que era sempre a história de um estudante universitário que tinha um rival meio vilão, meio perverso, mas ele sempre se saia bem. Eram filmes leves, com muitas canções, muitas músicas e danças, e cada filme era ambientado num lugar diferente [...] de repente resolvem fazer Rio no Wakadaishô, que seria rodado no Rio de Janeiro. A preparação para rodar o filme no Brasil coincidiu com a minha primeira ida ao Japão em 1968, integrando uma missão da Unesco. A Toho estava com dificuldade para conseguir os vistos, porque o pessoal da nossa embaixada em Tóquio era muito mal

\footnotetext{
35 A série Kurama tengu é comentada nos depoimentos de Marina Narahara e Ricardo Gonçalves. Os cinco filmes da Miyamoto Musashi, dirigidos por Tomu Uchida, são citados por Alfredo Sternheim, Olga Futemma e João Batista de Andrade, e comentado por Sedi Hirano, Carlos Reichenbach, Marina Narahara, Cláudio Willer, Jo Takahashi e Ricardo Gonçalves. A versão de Hiroshi Inagaki é citada por Hirano e comentada por Willer. Já a série Zatoichi é citada por Futemma e comentada por José Fioroni Rodrigues em Kobayashi (2003).
} 
preparado para atuar na área cultural. Eles estavam apegados a coisinhas burocráticas e não percebiam como era importante passar um filme japonês rodado no Rio de Janeiro [...] Nas sessões do Congresso da Unesco conheci uma moça nissei que atuava como tradutora e tinha um bom trânsito na embaixada do Brasil e eu contei para ela o problema e graças a ela saiu o visto do pessoal. Resultado: eu voltei para o Brasil no mesmo avião que vinha o Kayama Yuzo, os outros atores e o pessoal técnico que ia rodar o filme. Aí eu participei de tudo, das coletivas da imprensa com o Kayama Yuzo. Foi um momento bastante interessante, ter ajudado a confeccionar um filme japonês no Brasil.

O primeiro filmes japonês assistido por Ricardo Gonçalves na Liberdade foi uma das versões de Kurama Tengu, produzida nos anos 1950. Um dos críticos de cinema mais importantes do Japão, Tadao Sato, descreve o fascínio exercido por dois filmes da série junto ao público infantil, ainda na década de 1920. Isto estaria relacionado à atuação do ator Kanjuro Arashi, que, de 1927 a 1956, encarnaria o personagem em quarenta filmes da série:

Na série Kurama Tengu a trama gira em torno das aventuras de um bravo samurai, Kurama Tengu, e seu amigo leal, o menino Sugisaku, de forma que multidões de crianças aplaudiam, entusiasmadas, os feitos de seus heróis. Na série, o protagonista pertence ao movimento que luta pela unificação do Japão e pela devolução do poder ao imperador, mas a história de sua batalha contra o shogunato não é sobre ideologia. Ao contrário, o filme focaliza o seu nobre caráter, sua dedicação a uma causa justa e sua atitude gentil com as crianças. É por isso que, entre todas as estrelas da época, Kanjuro Arashi, um ator que projetou uma poderosa imagem de força e gentileza, elegância e lealdade, foi a melhor escolha para o papel de Kurama Tengu. Este personagem tornou-se sinônimo de Kanjuro Arashi e permaneceu na história do cinema japonês como seu papel de maior sucesso (Sato, s/d) [tradução do autor].

Se a atração exercida pelos filmes de chanbara sobre o público infantil é tão antiga, a ponto de nos remeter à época dos filmes silenciosos e da atuação dos katsuben, a produção de séries de filmes de ação visando deliberadamente este público, enquanto um segmento de mercado específico e de grande potencial constituiu uma estratégia da indústria cinematográfica japonesa do pós-guerra. A presença de um protagonista infantil, a abordagem do tema enfatizando as virtudes do herói, bem como o carisma de Kanjuro Arashi, explicariam o retorno do ator ao papel que o consagrou, quase trinta anos depois, numa produção de 1953 (Kurama tengu to Katsu Kaishû). Marina Narahara e Ricardo Gonçalves reelaboram lembranças de naturezas distintas relacionadas a esta série:

Eu me lembro dos filmes de samurais, que meus dois irmãos imitavam, um deles tem quatro anos a mais que eu. Então eles assistiam aos filmes de samurais e ficavam imitando em casa. Tinha fábrica e loja de móveis então tinha bastante madeira, e eles pegavam aqueles paus e ficavam imitando cenas de filmes, essas lembranças do meu irmão fazendo isso eu tenho. [Você lembra de algum filme em particular que eles gostavam?] Kurama Tengu, por exemplo, que era bem de samurai mesmo, em que ele cobria o rosto com um tecido assim e era o mocinho do filme, então matava todo mundo e saía vitorioso e os meus irmãos ficavam imitando isso, é isso aí que eu me lembro (Marina Narahara). 
Vou te contar como é que eu vi o primeiro filme. Eu era fascinado por cultura tradicional. Então eu via cartazes de filmes sobre assuntos modernos e não me interessava. Teve um dia que eu estava passando em frente ao Cine Niterói e eu vi uma figura num cartaz, um personagem com capuz preto e um revólver numa mão e uma espada de samurai na outra: Kurama Tengu. "É isso que me interessa! É esse filme que eu vou ver!" Isso foi em 1955 ou 1956. Então eu fui ver o Kurama tengu, que era um filme a respeito de um herói misterioso, naquele período de transição do Japão, fim do período Tokugawa e início da Era Meiji. Era um herói que atuou nesta passagem do feudalismo para o Japão moderno. E foi uma descoberta maravilhosa! "Puxa, este tipo de coisa que eu gosto mesmo!" Aí eu fiquei na espreita: cada vez que tinha filme de samurai, lá estava eu para assistir (Ricardo Gonçalves).

$\mathrm{Na}$ época dos episódios narrados, Ricardo Gonçalves já era estudante do curso secundário, demonstrando um interesse pela cultura tradicional japonesa, enquanto Marina Narahara era ainda uma criança de nove ou dez anos de idade. A idade em que o filme foi visto e os interesses da pessoa na época podem influir no tipo de significação associada ao filme: no caso de Marina, de natureza familiar, dos irmãos imitando o personagem do filme. Já Ricardo, tendo sido depois professor do Departamento de História da Universidade de São Paulo especializado em história oriental, situa o personagem na passagem da Era Tokugawa para a Era Meiji.

Ao apostar sempre nas mesmas fórmulas de sucesso, a produção em série das companhias cinematográficas japonesas teria gerado uma certa padronização, conformando parte dos filmes realizados na época. Para Eunice Yokota, os filmes japoneses assistidos na infância e aqueles reconhecidos internacionalmente parecem pertencer a universos diferentes. Dos primeiros, do que ela se lembrava era da sensação de repetição e de previsibilidade, que tornava a experiência de assisti-los comparável à audiência de um filme norte-americano do passado ou de uma telenovela brasileira atual:

E achava que os filmes japoneses puxavam muito para o lado emocional, a não ser esses filmes do Ozu ou do Kurosawa, que já faziam filmes de outro tipo. Mas a maioria dos diretores fazia aquela coisa parecida com novela, sempre igual, aquele roteiro mais ou menos parecido, os artistas parecidos, como se você estivesse vendo o mesmo filme, várias vezes. Pareciam os filmes norte-americanos de alguns anos atrás. A coisa vai se repetindo, muda o artista, muda o diretor, mas o roteiro era previsível. Quando eu ia com meus pais nesses cinemas, a gente ia porque não tinha nada mais nada para fazer, não era porque o filme era importante. Porque na verdade a coisa se repetia, era como ver capítulos de uma novela. Era muito parecido com isso, a não ser um filme ou outro.

Essa sensação de repetição e de previsibilidade também é descrita a respeito de um dos 46 episódios da série É triste ser homem (Otoko wa tsurai yo) [Fig. 18]. Em artigo publicado no jornal O Estado de S. Paulo sobre do lançamento do $23^{\circ}$ episódio, Otoko wa tsurai yo Tonderu Torajiro, o crítico de cinema Rubem Biáfora (1981b) comenta: 
Pobre Yoji Yamada. É o diretor mais bem-sucedido comercialmente do atual cinema japonês. Tem, porém, de pagar um preço: ater-se quase que exclusivamente aos filmes desta série "Tora San", o eternamente simplório e casadouro caixeiro-viajante interpretado por Kiyoshi Atsumi. Aqui, o personagem enfrenta o mais inusitado de seus habituais desenganos amorosos, pois começando a se interessar por uma mocinha, acaba na verdade enamorado da mãe da mesma. E esta outra não é senão a veterana Michiyo Kogure [...].

Entre os filmes marcantes assistidos na Liberdade, Jo Takahashi menciona essa mesma série. Seu comentário indica o tipo de reação despertada junto ao público, isto é, como a reelaboração de uma mesma fórmula em vários filmes continuou a emocionar sua audiência:

Eu destacaria É triste ser homem pela continuidade. Mas mesmo dentro da continuidade e mesmo dentro da fórmula, a mesma equação sempre, o mesmo começo-meio-e-fim, Yamada Yoji consegue despertar muita emoção e muita humanidade.

A realização de diferentes versões cinematográficas de uma mesma história, provenientes em grande medida da literatura produzida no país, contribuiria também para a percepção do efeito de repetição e de previsibilidade: Chushingura (The Loyal Fourty-Seven Ronin), peça clássica do repertório do teatro kabuki, teve 85 adaptações para o cinema, realizadas de 1907 a 2005 (Richie, [2001] 2005); cinco adaptações cinematográficas de $A$ dançarina de Izu (Izu no odoriko), romance de Yasunari Kawabata, foram produzidas de 1933 a 1974, das quais Marina Narahara lembra-se da segunda, estrelada por Misora Hibari (Fig. 19) ${ }^{36}$; Musashi, o romance de Yoshikawa, teve sete diferentes adaptações cinematográficas (Reichauer, [1981] 1999), sendo que as mais lembradas por freqüentadores dos cinemas da Liberdade são os cinco episódios da Toei dirigidos por Tomu Uchida, e a trilogia produzida pela Toho (1954-1956) e dirigida por Hiroshi Inagaki ${ }^{37}$; A espada diabólica (Daibosatsu Toge), um romance de Nakazato Kaizan, teve versões produzidas pela Toei (Tomu Uchida, 1957 a 1959), pela Daiei (Isei Mori, 1961) e pela Toho (Kihachi Okamoto, 1966) ${ }^{38}$; Shohei Imamura dirigiu a segunda adaptação cinematográfica de A balada de Narayama em 1983; e uma nova versão de Zatoichi foi dirigida e protagonizada por Takeshi Kitano em 2003.

E como interpretar a popularidade de tantas seqüências de uma mesma série e de tantas versões de uma mesma história?

\footnotetext{
36 "Misora Hibari é aquela cantora lá super famosa. Esse eu assisti: Izu no Odoriko (1954). Izu no Odoriko é um filme que muitos diretores refilmam. É do Kawabata Yasunari, aquele escritor que se suicidou, e ele que escreveu e foi filmado. Então, acho que tem umas quatro versões de Izu no Odoriko, o dela é a segunda versão" (Marina Narahara).

${ }^{37}$ A primeira parte desta trilogia da Toho, com o título em inglês de The Legend of Musashi (1954), conquistou um Oscar (Academy Award) honorário.

${ }^{38}$ SILVER, Alain. The Samurai Film. Woodstock, The Overlook Press, [1977] 1983.
} 
Considerado um dos maiores especialistas em cinema japonês do Ocidente, Donald Richie (2005: 11) chama a atenção para o eixo de polaridades constituído entre o ethos 'presentacional' [presentational ethos], que ele teria encontrado mais na Ásia do que no oeste, e o ethos representacional, cuja presença ele teria percebido mais fortemente no oeste do que no continente asiático ${ }^{39}$. Enquanto o ethos representacional seria realista e assumiria que a "realidade" em si mesma estaria sendo apresentada, o presentacional a presentificaria [presents] através de várias estilizações, sem assumir que a realidade crua estaria sendo mostrada. $\mathrm{O}$ realismo fílmico seria uma dentre outras variedades de estilização, cuja posição não teria sido tão privilegiada no Oriente quanto seria no Ocidente.

De acordo com Richie, as formas dramáticas japonesas mais antigas teriam assumido a necessidade de uma estrutura criada através da mediação ${ }^{40}$. A respeito disso, o pesquisador e professor de cinema João Luiz Vieira observa um aspecto central do método e da visão de mundo de Kenji Mizoguchi: o gosto do cineasta de inscrever o espectador dentro da diegese dos filmes, isto é, como parte dos elementos que compõe o espaço fílmico, tornado mais intrincado o sentido de observação de seu trabalho de câmera. Vieira comenta o exemplo da cena do suicídio da personagem Anju, em Intendente Sansho (Sansho Dayu, 1954), que é vista por meio de um amigo, impotente para evitar a tragédia, assim como o espectador na platéia:

Essa estrutura expressa [...] o jogo necessário entre distanciamento e identificação, trazendo para o cinema um aspecto crucial da arte e da estética japonesas: a presença de um observador solitário numa cena, como parte integrante de muitas artes. A existência de pequenas figuras em interação com a paisagem aparece na pintura japonesa de épocas diversas da mesma forma que o teatro, tanto o bunraku como o kabuki, incluem narradores que descrevem e respondem à ação no palco. A tradição, como sabemos, permanece nas três primeiras décadas do cinema no Japão com a figura do benshi, o narrador que contava e interpretava o filme para a platéia [...] É nesta tradição que Mizoguchi faz com que assistamos, simultaneamente, um evento e seus efeitos num observador humano (Vieira, 1990).

Richie afirma que os assuntos dos primeiros filmes japoneses eram teatrais: cenas de peças clássicas do kabuki ou seções do shimpa. Esses dois gêneros de teatro eram tidos como separados: kabuki seria a "velha escola", enquanto que shimpa, a "nova escola"; essa distinção moldaria as formas tomadas pelo nascente cinema japonês: filmes baseados no kabuki

\footnotetext{
${ }^{39}$ Segundo o próprio autor, o eixo presentacional-representacional seria um esquema interpretativo familiar aos historiadores do cinema japonês. Ele é trabalhado também por estudiosos do teatro oriental, como Richard Schechner e Victor Turner (1982), e por pesquisadores do cinema japonês como Noël Burch.

40 "O mesmo seria verdade com a cultura japonesa em geral: a selvageria se tornaria natural somente depois de ter sido moldada e apresentada numa forma palpável, como no jardim japonês, ou nas flores que são consideradas vivas [ikebana] apenas depois de terem sido cortadas e arranjadas para serem vistas" (Richie, ibidem) [tradução do autor].
} 
tornaram-se os jidaigeki, os filmes de época, enquanto as películas baseadas no shimpa constituíram os primórdios dos gendaigeki, ou dramas contemporâneos. Caracterização semelhante havia sido formulada por Paulo Emílio Sales Gomes, em um artigo publicado no jornal $O$ Estado de S. Paulo, já em agosto de 1957:

A história do cinema japonês conheceu a clássica dualidade Tóquio-Kyoto, tradição e modernismo. Na antiga capital desenvolveu-se durante anos o cinema no estilo kabuki, enquanto na metrópole promovia-se a filmagem de histórias contemporâneas. Embora Kyoto não seja mais centro de produção, os dois delineamentos gerais de estilo são até hoje conservados, de um lado o filme histórico de samurais e bandidos e de outro os dramas modernos. Essas duas direções cinematográficas foram, em suas origens, expressões da diversificação que se operou no teatro. [...] O grande espetáculo era constituído pelo kabuki e seus derivados, entre os quais o shimpa, o que mais se afastou do tronco original, tendo-se aberto deliberadamente a todas as influências ocidentais. A raiz do estilo cinematográfico de Tóquio é uma combinação do shimpa teatral com as lições dos filmes estrangeiros. Seu resultado mais característico é o melodrama para provocar lágrimas, que teve no Japão uma voga imensa e cuja marca continua presente na produção contemporânea de estilo moderno (Gomes, [1957a] 1981: 172).

A apresentação de uma realidade mediada por formas de estilização pode ser ainda exemplificada pelas observações de José Fioroni Rodrigues acerca de três filmes do cineasta Keisuke Kinoshita exibidos no Brasil:

Outra faceta de Kinoshita era procurar um modo diferente de fazer seus filmes. Poesia do meu primeiro amor, todo baseado em recordações, foi filmado como aquelas fotos antigas, ovaladas e cercadas por um espaço branco, o que prejudicava a película, tornando-a cansativa. Já Balada de Narayama era uma peça de teatro filmada, em que se viam as mudanças de cena como se estivéssemos nos bastidores. Em Murmúrios do rio Fuefuki, ele usou um sistema de colorir partes do filme com uma só tonalidade, ora verde, ora azul, e assim por diante; e em algumas cenas que ficavam estáticas, o colorido foi feito à mão. Todas essas pretensas inovações não pegaram, felizmente (Rodrigues, 1995: 168).

Em 1971, Richie argumenta que, apesar de Kinoshita utilizar tanto a cor quanto o formato widescreen para realizar A Balada de Narayama (Narayama Bushi-ko, 1959), ele teria se apoiado fortemente em efeitos de palco [stage effects], emoldurando a história com dispositivos tirados do kabuki. Em alguns momentos este filme se assemelharia a um teatro filmado. O mesmo ocorreria com Murmúrios do rio Fuefuki (Fuefukigawa, 1960), uma crônica sobre cinco gerações de uma família de agricultores pobres durante o século XVI. Este filme conteria também uma rica teatralidade, enfatizada pelo uso da cor, que imitaria propositalmente as primeiras xilogravuras japonesas. $\mathrm{O}$ uso de fotografias estáticas nas cenas de batalha provocaria efeitos tanto de interrupção quanto de manutenção da ação. No entanto, ao contrário de Rodrigues, Richie argumenta: "Embora essa técnica possa ser descrita como uma inovação, alguém poderia notar sua similaridade extrema com os kami-shibai, o antigo 
teatro de gravuras [paper-slide theater], que meninos e meninas do Japão ainda amam" (Richie, 1971: 99) [tradução do autor].

Narayama Bushi-ko teria sido exibido em São Paulo no Cine Niterói em setembro de 1959, com o título A lenda de Narayama (Ohno, 1964: 57). Olga Futemma, no entanto, afirma que o lançamento do filme em 1959 teria inaugurado um período feliz da distribuição japonesa em outras salas de cinema, isto é, esse filme seria um dos primeiros a atravessar as fronteiras da Liberdade e atingir o público ocidental (Futemma, 1986: 79). Eunice Yokota lembra-se de ter assistido ao filme num cinema de arte. Mas o que impressionou Eunice e as irmãs Clara e Teresinha Nakayama teria sido mesmo o enredo do filme, uma adaptação do romance de Shichiro Fukuzawa sobre a vida em um vilarejo onde os filhos são coagidos pelo costume a levar seus pais idosos ao Monte Narayama para morrer (Fig. 20):

Um filme também que me marcou bastante foi $A$ balada de Narayama, é muito triste. [Teresinha: Quando chega uma certa idade...] carrega a mãe nas costas e sobe montanha acima, levando onigiri [bolinho de arroz]. Esse filme me marcou bastante, é muito triste (Clara Nakayama).

Eu vi num cinema de arte, eu lembro ter visto aquilo, mas que coisa mais impressionante, Meu Deus do céu! Muito bonito. Muito bem feito e lírico, num tema que é bem pesado. Foi interessante porque eu assisti a uma palestra de um psicanalista, em que ele cita esse filme como exemplo do desenvolvimento da vida comunitária, em que você tem alguns elementos que são escassos e que leva a esse tipo de solução. É um filme muito triste e ao mesmo tempo bastante lírico (Eunice Yokota).

O escritor e crítico de cinema Jean Claude Bernardet relembra a experiência de assistir a uma peça do teatro kabuki numa viagem ao Japão, da qual participaram outros realizadores e críticos do cinema brasileiro, como Ismail Xavier, além de Jo Takahashi da Fundação Japão. Ele contrapõe a relação de fascinação dos ocidentais com o teatro kabuki, com a relação de familiaridade dos espectadores japoneses com o enredo das peças:

Bom, um ou dois dias depois o Jo [Takahashi] consegue ingressos para o teatro kabuki. Chegamos lá pelas dez, onze horas da manhã e fomos até as seis da tarde. Foi absolutamente extraordinário! [...] Ismail [Xavier] e eu ficamos absolutamente deslumbrados. É um grande teatro barroco, é uma palavra que o japonês talvez jamais usasse para o kabuki, mas era para mim, mesmo sem entender, os ritmos são fascinantes, as luzes, ficamos horas. Eu e o Ismail poderíamos ficar cinco, dez horas que fosse, porque é muito importante você ter o conhecimento da gestualidade que é muito significativa, que obviamente nós não tínhamos. [Isto estaria na base de uma parte do cinema japonês.] Exatamente. Também o fato de que todos os enredos já são amplamente conhecidos, porque estas pessoas, depois lendo [Junichiro] Tanizaki você percebe isto, estas pessoas já viram estas peças, várias vezes. Eé muito importante para elas uma pequena diferença que um ator, uma atriz faça, em relação 
a uma outra representação que eles viram no ano passado. Mas nós não tínhamos isto. Então tivemos uma relação de ocidental, mas uma relação de fascínio ${ }^{41}$ [grifo do autor].

Richie argumenta que o realismo como estilo foi aos poucos influenciando o emergente cinema japonês. Os cinejornais da época da Primeira Guerra Mundial, o crescimento da importação de filmes ocidentais e o shingeki, uma nova forma de teatro seriam as causas da mudança. No entanto, ele identifica no comportamento do público de cinema japonês a continuidade da influência teatral:

No início, a audiência japonesa percebeu o cinema como uma nova forma de teatro, ao contrário das platéias de outros lugares, como nos Estados Unidos, em que ele foi percebido como uma nova forma de fotografia. Quase todos os primeiros filmes narrativos japoneses foram tirados dos palcos teatrais. Se isso já não é mais assim, a audiência dos filmes japoneses ainda se comporta como se estivesse no teatro: os espectadores de cinema tomam seus lugares ao início da sessão, ou seja, assistir a um filme não é encarado como um entretenimento circular, em que se entra e sai a qualquer hora. Ao contrário, ele tem suas regras narrativas próprias que devem ser respeitadas. Integrantes de audiências japonesas raramente saem da sala de cinema no meio da projeção e freqüentemente se mantêm sentados até o fim da exibição dos créditos do filme. Os filmes são assistidos em silêncio, num contraste marcado com hábitos de cinema de outros lugares, mas semelhante ao comportamento do público de teatro ocidental (Richie, [2001] 2005: 22) [tradução do autor].

Trinta anos antes, ele observou que o público japonês de cinema considerava o muito familiar prazeroso, ao contrário do público ocidental para quem isso seria uma das primeiras fontes de aborrecimento, e que não haveria país em que um clichê bem empregado [ $a$ wellturned clichê] fosse tão admirado. O cinema japonês não seria constrangido a evitar o enfadonho [boredom], seja indiretamente, pelo emprego dos clichês e dos truísmos, seja por meio da lentidão e da inatividade. Haveria ainda uma correspondência entre a familiaridade do público do teatro kabuki com as peças de seu repertório, citada por Bernardet, e o pacto estabelecido entre os realizadores e os espectadores dos filmes japoneses, o que talvez explique a popularidade das séries de filmes e das várias versões de uma mesma história:

Muitos espectadores ocidentais reclamam que não conseguem acompanhar, digamos, um filme japonês histórico comum. A razão disso é que o diretor assume, corretamente, que a audiência japonesa já conhece a história tão bem, que ele não precisa construir o que chamaríamos de uma trama convincente e personagens compreensíveis. Às vezes isso resultaria em alguns mal-entendidos, como quando críticos ocidentais consideraram a versão de Inagaki de 1962 de Chushingura audaciosa, identificando elementos semelhantes aos cortes de continuidade de Godard, quando tudo o que o diretor fez foi pular de uma cena celebrada para a próxima (Richie, 1971: 18) [tradução e grifo do autor].

\footnotetext{
${ }^{41}$ Conforme entrevista concedida por Jean Claude Bernardet ao autor, em 10 de julho de 2009.
} 


\subsection{Filmes norte-americanos e japoneses: diferenças de ritmo}

No artigo "Cinema japonês: um olhar pessoal" (1996), Richie descreve sua aproximação com essa cinematografia a partir de sua experiência no Japão, primeiro como membro das forças da ocupação norte-americana no país, e, a partir da década de 1950, como pesquisador e crítico de cinema. Na época de sua chegada, era proibido aos ocupantes freqüentarem lugares como kabuki, salão de dança, bordéis e cinema. Ele conta que quem fosse apanhado pela polícia militar seria punido e mandado de volta aos Estados Unidos: "Eu não queria isso, Ohio de novo, não. No entanto, corria esse risco porque, embora pudesse imaginar uma vida sem kabuki ou bordel, não poderia concebê-la sem filmes" (Richie, 1996: 63). Ele faz uma descrição de sua primeira ida clandestina a um cinema: o Gekijo Tokyo Kurabu em Asakusa, bairro de Tóquio, em março de 1947. Naquela época, a popularidade do cinema no Japão era tanta, que as salas de cinema comportavam apenas espectadores em pé:

Assim, tive que ter coragem: olhei ao longo da Asakusa Rokko e, não vendo a PM, me esgueirei no cinema. [...] O cinema estava abarrotado e eu, apertado contra a parede do fundo, olhava a tela nua, esperando o filme começar. [...] As pessoas em pé comprimidas contra mim, sabiam que eu estava transgredindo: seus olhares passavam por mim cuidadosamente desfocados enquanto esperavam pela escuridão. Ninguém queria reconhecer um estrangeiro no cinema, éramos proibidos. [...] Vi-me de pé, espremido lá no fundo, respirando o suor das pessoas, que então cheirava arroz misturado à fragrância da pomada de óleo de camélia que os homens costumavam passar no cabelo e, mais além, o delicioso cheiro do vazio vasto, frio, empoeirado e promissor atrás da tela. E então as luzes se apagaram (idem, ibidem: 62-63).

Após assistir a muitos filmes, ele começa a identificar algumas características específicas dos filmes japoneses. Como não poderia deixar de ocorrer, tais características, no entanto, seriam percebidas com relação à sua referência de cinema, isto é, os filmes norteamericanos produzidos até o final dos anos 1940 e assistidos em Ohio. Na comparação entre os filmes japoneses e os norte-americanos, três aspectos são destacados - o ritmo lento dos primeiros em relação à agilidade dos segundos, a prevalência dos planos gerais nos filmes japoneses em contraste com o primado dos close ups nos norte-americanos, e a sua alergia aos exibicionismos das atrizes de seu país em oposição à sua adesão à emotividade das japonesas:

Reparei também no ritmo dos filmes desse período [1945-1949]: lento, muito lento. Era preciso muito tempo: cenas longas, seqüências longas. Sentimentos fluíam e floresciam em durações que Ohio acharia extravagantes. A tela inundava-se de uma emoção sem comportas. Apesar de alérgico aos exibicionismos de Joan Crawford e Bette Davis, não me importava com a emotividade das mulheres que mais tarde descobri serem Kinuyo Tanaka e Hideko Takamine (Figs. 21 e 22). Perguntando-me porque chorava tão espontaneamente com elas, percebi que, pelo fato de estarem tão longe e chorando por tanto tempo, 
compeliram-me a chegar mais perto e a sentir mais. Isso era muito diferente do enorme e exigente close up de Joan, com narinas tão largas que podiam sugar um caminhão. Sem nenhuma solicitação aparente, eu dava mais [...] estava tendo a minha primeira aula de arte japonesa (Richie, 1996: 64).

Em 1971, ele cita uma reclamação corrente de que os filmes japoneses seriam considerados longos demais, fardo atribuído por espectadores ocidentais tanto aos filmes de Yasujiro Ozu quanto aos de luta de espada. Ele argumenta que os filmes pareceriam longos na medida em que eles não se movem da maneira que esperaríamos que eles se movessem. Tendo os filmes de Ozu ou os de lutas de espada a mesma duração média dos longametragens norte-americanos (de noventa a 120 minutos), a alegação da duração excessiva daqueles seria metafórica, isto é, relacionaria-se mais ao ritmo do filme, conseqüentemente à decupagem dos planos e ao seu encadeamento na montagem: longo e lento teriam assim o mesmo sentido.

Há, por um lado, a percepção de que essas categorias são sempre relativas: longo ou lento em relação a quê? Em relação às referências de cinema do espectador, pois se em 1971 Richie refuta a reclamação de espectadores ocidentais, ele teria passado por experiência semelhante em 1947. Por outro lado, parece haver o reconhecimento de um ritmo lento que efetivamente caracterizaria os filmes japoneses produzidos na época, decorrente da presença de cenas e de sequiências longas nos filmes. Isso estaria relacionado a uma particularidade das expressões artísticas do Japão, pois ele argumenta que, para os japoneses, os sentimentos de uma pessoa só operariam completamente depois de uma certa quantia de exposição. No teatro, na música e nos filmes seria necessário tempo para a completa imersão do espectador.

A percepção do ritmo lento seria causada também pela proeminência dos planos gerais sobre os planos de detalhe, pois uma cena decupada em diversos planos apresenta-se com mais dinamismo do que a mesma observada de um ponto de vista fixo. Richie escreve que, se os filmes norte-americanos são os mais fortes na ação, e os europeus o são na construção dos personagens, os filmes japoneses são os mais ricos na construção da atmosfera, isto é, em apresentar os personagens em meio àquilo que os cerca (Richie, 1971: VII): “A câmera parecia sempre mais distante dos atores, como para mostrar o espaço que a separa deles. Um personagem devia ser explicado por um plano geral, o ambiente falava por ele. Às vezes, eu não podia sequer distinguir um rosto, mas descobria de quem se tratava pelo que havia ao seu redor" (idem, 1996: 64).

Conforme descrito na página 8 do capitulo 1, o primeiro filme que Olga Futemma assistiu na vida foi um filme de samurai no Cine Niterói, aos nove anos de idade. Ela assistia 
apenas aos filmes japoneses até os 12 ou 13 anos, época em que, acompanhando a irmã mais velha, descobre o Cine Metro, o Cine Paissandú, o Cine Marabá, e o Cine Ipiranga, passando a identificar atores como Doris Day, Rock Hudson e Shirley MacLaine, e distanciando-se, a partir daí, do cinema japonês. A trajetória de Sedi Hirano é inversa: aos 14 ou 15 anos, junto com o curso ginasial, ele passa a trabalhar como cobrador de seguros, atividade que lhe rende tempo livre para freqüentar a Biblioteca Municipal e os cinemas da Cinelândia Paulista como o Cine Marrocos e o Cine Coral. Nessa época, Hirano apreciava os westerns dirigidos por John Ford. O primeiro contato com o cinema japonês ocorreu depois, por intermédio de um colega do curso científico do colégio Roosevelt. Futemma e Hirano estabelecem comparações entre o cinema norte-americano e o japonês, especialmente entre os westerns e os filmes de samurai, enfatizando aspectos relacionados ao tempo e ao ritmo:

\begin{abstract}
Esses filmes de samurai tinham um desenvolvimento completamente diferente do cinema americano. Era o filme inteiro uma grande preparação. Mesmo que no western tenha o duelo final, nos filmes de samurai a economia desse grande momento é radical. Num desses filmes o personagem pega um barco, apronta a arma dele, afiando um pedaço de pau. De repente estão na praia [fica com os dedos indicadores das mãos separados], se olham por muito tempo, um tempo que não é de cinema americano, e de repente eles fazem: - Ohooi! [os indicadores se juntam], eles dão um salto, e acabou. Se você piscou naquele momento você não sabe o que foi que aconteceu. Eu achava genial, isso é economizar, não fica aquela coisa tcha-tcha-tcha [gesticula os dedos], não precisa de uma grande coreografia, é econômico mesmo (Olga Futemma).

É claro que de início, de tanto você assistir filme norte-americano, existe um problema de ritmo, o cinema japonês tem um ritmo completamente diferente. E cinema americano é cheio de tiroteio, dependendo, se é faroeste, então os dramas transcorrem com uma certa rapidez. O tempo é diferente. Culturalmente os tempos são diferentes e, portanto, a linguagem é muito diferente (Sedi Hirano).
\end{abstract}

Da mesma forma que Hirano, Jean Claude Bernardet especula que, para um japonês, o ritmo lento dos filmes japoneses poderia corresponder ao seu ritmo de vida, ao ritmo de sua cultura. Ele fundamenta essa observação a partir de sua própria experiência como espectador e imigrante, que se reconheceu em certos costumes e gestos observados em filmes franceses. Neste ponto, Bernardet afirma a apreensão diferenciada por parte dos imigrantes e de seus filhos dos filmes produzidos em seus países de origem, aproximando-se das reflexões de Hikiji (1998a) e Caiuby Novaes (2005) a respeito do cinema como meio que veicula valores, modos de vida e pensamentos que encontram ressonância na experiência do espectador:

Havia um cinema mais para a colônia [japonesa]. Primeiro, porque o que chegava ao Brasil, principalmente a São Paulo, era infinitamente menos filtrado do que o que chegava a outros países por causa da colônia, e é natural que pessoas nascidas no Japão ou de primeira geração, vendo filmes que fossem, digamos, de costumes, dos seus pais ou do país de 
origem, compreendessem e se interessassem por estes filmes de uma maneira que não seria a de um ocidental, por mais que ele gostasse de cinema japonês. Porque isso eu percebi em relação aos filmes franceses - que eu não sou japonês, mas sou um imigrante - que havia coisas em filmes franceses que para nós são muito significativas. Eu me lembro, por exemplo, da maneira como o Jean Gabin comia queijo num botequim, não me lembro em que filme. Aquilo era tipicamente parisiense, para quem tivesse vivido lá, para quem conhecesse estes costumes, então sim, se encontravam nestes costumes. Isto aconteceu com a colônia japonesa, e mesmo filmes que foram apreciados por brasileiros, podiam ser apreciados pela colônia de uma maneira totalmente diferente, com outras referências. $\mathrm{O}$ ritmo lento de um Naruse, de um Ozu, pode ser um ritmo cinematográfico, o ritmo da narrativa. Talvez para o japonês fosse o ritmo de vida, um ritmo cultural.

\subsection{Singularidade de São Paulo}

O reconhecimento internacional do cinema japonês teve início com a conquista do Leão de Ouro (Prêmio de Melhor Filme) do Festival de Veneza de 1951 por Rashomon (1950), de Akira Kurosawa (Fig. 23). Em 1952, o filme ganharia ainda o Oscar (Academy Award) de Melhor Filme Estrangeiro entre outros prêmios, fazendo dele, por um certo tempo, o filme asiático mais assistido no Ocidente (Richie, 2005: 139). Nos anos seguintes e no rastro de Rashomon, vários filmes japoneses conquistaram prêmios nos principais festivais de cinema do mundo: dois filmes dirigidos por Kenji Mizoguchi, Oharu: A vida de uma cortesã [1952], e Contos da lua vaga depois da chuva [1953], foram agraciados com o Leão de Prata no Festival de Veneza, o que na época equivalia ao reconhecimento pela segunda colocação na competição internacional; o mesmo prêmio foi conquistado em 1954 por Os sete samurais (1954), dirigido por Kurosawa; no mesmo ano, o filme A porta do inferno (1953, Teinosuke Kinugasa), seria laureado com o prêmio máximo do Festival de Cannes, a Palma de Ouro, concedida ao vencedor da competição (Internet Movie Database).

Em São Paulo, Rashomon foi exibido em 1952 no Cine Odeon (Ohno, 1964: 55) e em dezembro do mesmo ano, no Cine Ipiranga. Em 1954, o filme Os sete samurais estreou nesta mesma sala de cinema, após a conquista do prêmio de Veneza (Almeida Salles, [1956] 1988: 183). Dez anos teriam se passado entre a produção de Contos da lua vaga depois da chuva e sua exibição na cidade de São Paulo, em 1963, numa sessão especial promovida pela recém inaugurada Sociedade Amigos da Cinemateca, da Cinemateca Brasileira (Ohno, 1964: 24). Em 1957, no entanto, um dos diretores dessa instituição, Paulo Emílio Sales Gomes, afirmou que fazia cinco anos que ele não revia Oharu, ou seja, ele teria assistido ao filme de Mizoguchi no mesmo ano em que foi produzido (Gomes, [1957c] 1981: 180). Num dos primeiros livros no Brasil sobre o tema, O filme japonês, publicado em 1963 pelo Grupo de Estudos Fílmicos, João Ribeiro menciona que apenas dois filmes de Teinosuke Kinugasa seriam conhecidos no 
país: O crime da quinta, exibido há muitos anos, e Ases do trapézio (Hibana). Nesse livro, não há nenhuma menção ao filme A porta do inferno, nem mesmo na seção "Filmes de Samurai", redigida por Moacyr Nilson. Não foram encontrados indícios de que esses filmes premiados tenham sido exibidos nos cinemas da Liberdade.

Em agosto de 1957, a Cinemateca Brasileira em parceria com o Cine Niterói promoveu o ciclo Cinema Japonês Moderno, mostra de filmes japoneses produzidos no pós-guerra que ocorreu no auditório do Museu de Arte Moderna, localizado na rua Sete de Abril. Nesse contexto, Gomes publicou no jornal $O$ Estado de $S$. Paulo três artigos consecutivos sobre a história e a situação contemporânea do cinema japonês, apoiando-se principalmente no livro publicado em francês de Shinobu e Giuglaris (1956). ${ }^{42}$ A respeito da produção japonesa daquele momento, ele distinguia, de um lado, a massa de filmes para consumo interno, e de outro, as obras destinadas aos festivais. O interesse do ciclo proporcionado pelo Cine Niterói à Cinemateca Brasileira teria sido o de permitir a apreciação de uma amostra de filmes do primeiro grupo, afirmação que indicaria uma certa separação existente entre os freqüentadores das sessões da Cinemateca e o público habitual das salas de cinema da Liberdade.

Em "Atualidade Japonesa", Paulo Emílio Sales Gomes descreve as seis companhias cinematográficas japonesas como trustes gigantescos, proprietárias de bancos, estúdios, cadeias de distribuição e salas de exibição, cada qual lançando um filme por semana. Ao contrário das demais companhias, a Daiei não dispunha de uma distribuidora e contaria com poucas salas de cinema. As escassas possibilidades de escoamento interno teriam levado a empresa a buscar o mercado estrangeiro: "De início o campo de exportação da Daiei limitouse a Okinawa, Formosa, Hong Kong, Havaí e às colônias japonesas nas Américas" (Gomes, [1957b] 1981: 177). Ele argumenta que o sucesso dos jidaigeki [filmes de época] nos festivais de cinema internacionais teria sido, segundo o presidente da Daiei, Masaichi Nagata, fruto de uma observação metódica e de uma ação calculada:

Procedeu-se então o estudo cuidadoso dos mercados internacionais e se chegou à conclusão de que o terreno mais favorável eram os países europeus, particularmente os latinos. "Ficou decidido", explica Nagata, "que nos lançaríamos em filmes de roupagens, históricos, exóticos e culturais para enfrentar os festivais europeus, sobretudo Cannes e Veneza". Esses filmes deveriam, ainda nas palavras do chefe da Daiei, "agradar as pessoas que têm um complexo pela tragédia, que são apaixonadas pelos séculos passados, que se orgulham de sua cultura e de sua espiritualidade". Para isso, o fundo dos filmes devia ser constituído de "velhos templos e palácios, testemunhos da cultura" e na ação deviam participar ao mesmo tempo "princesas com sentimentos complicados e heróis masculinos, selvagens e guerreiros" (Giuglaris, 1956). Para se ter uma idéia do sucesso que acolheu a nova política, basta lembrar o título de dois de seus produtos, Rashomon e A porta do inferno.

\footnotetext{
${ }^{42}$ Shinobu e Giuglaris, Marcel. Le Cinema Japonais. Paris, Les Editions du Cerf, 1956.
} 
Oito anos depois do artigo de Gomes, Donald Richie publicou o livro Os filmes de Akira Kurosawa ([1965] 1984), em que conta uma versão bem diferente da escolha de Rashomon como o representante japonês no Festival de Veneza. Nagata teria saído indignado da primeira projeção do filme, o qual dizia não compreender. O sucesso internacional de Rashomon não teria sido resultado de uma ação calculada. Permanece, no entanto, a percepção do direcionamento apenas dos filmes de época para os mercados cinematográficos ocidentais, bem como da lógica da indústria cinematográfica de apostar na mesma fórmula de sucesso:

Quando o filme foi recomendado para ser inscrito no Festival de Veneza, a sugestão foi recebida com muita oposição, especialmente da Daiei, que não tinha esperança nem fé no filme. Foi com grande relutância que eles concordaram com sua remessa para o festival de 1951, em que ele ganhou o grande prêmio. O fato de o filme ganhar o prêmio de cinema mais conceituado da época foi como um choque para o Japão. Mas o que talvez tenha surpreendido mais os japoneses foi que um filme histórico se revelasse aceitável no Ocidente. Isso levou a uma erupção dos filmes históricos dirigidos ao Ocidente, do qual $O$ portal do inferno é o único sobrevivente, mas no início os críticos não sabiam como explicar o fato de ele ter recebido o prêmio e a sua conseqüente popularidade nos outros países. Por fim resolveram que era porque o filme era exótico (no sentido em que $O$ portal do inferno realmente é exótico, e pouco mais que isso) e que os estrangeiros gostavam do exótico. [...] Embora a Daiei não tenha segurado o diretor, ela seguiu a máxima comum a todas as companhias cinematográficas: se você tem um sucesso, repita-o. No ano seguinte, Keigo Kimura da Daiei produziu A bela e os bandidos, inspirado diretamente de Rashomon, e o bem melhor Contos de Genji, de Kimisaburo Yoshimura (Richie, 1984: 79-80).

Exibido no Brasil com o título Amores de Genji, o filme de Yoshimura foi o primeiro a ser lançado no Cine Niterói, em 24 de julho de 1953, um dia após a inauguração do prédio que acomodava a sala de cinema, e teria ficado duas semanas em cartaz com sessões lotadas. Os filmes seguintes exibidos no Niterói foram o gendaigeki [drama contemporâneo] Mamãe (Okasan, 1952), de Mikio Naruse (Fig. 24) e a comédia Tambor Roto (Yabure Daiko, 1949) de Keisuke Kinoshita (Moribe, 1991; Kobayashi, 2005).

Assim como Gomes e Richie, Maria Roberta Novielli ([2001] 2007), pesquisadora e professora de cinema e literatura japonesa na Universidade Ca'Foscari de Veneza, atenta para a relação entre o direcionamento dos jidaigeki (filmes de época) para os festivais e mercados cinematográficos ocidentais com a imagem exótica do Japão que era apresentada por esses filmes. O cinema japonês exportado seria quase exclusivamente o de época. As comédias, como essa que estreou no Cine Niterói ou aquela série sobre o presidente da empresa citada por Ricardo Gonçalves, não teriam sido distribuídas na Europa, assim como os gendaigeki de cineastas como Yasujiro Ozu e Mikio Naruse, cujo filme Sofrimento (Sobo, 1933), por exemplo, teria sido exibido no Cine Theatro São Paulo já em 1940 (Ohno, 1964: 44): 
Aberto o caminho para o Ocidente, os sucessos internacionais estiveram quase na ordem no dia: um Oscar para Rashomon, uma longa série de prêmios em Veneza, em Cannes, e, depois, em Berlim. O Japão entrara triunfalmente no circuito dos grandes festivais, propondo, sobretudo, a fórmula vencedora do primeiro grande premiado, ou seja, a ambientação no passado. Masaichi Nagata, presidente da Daiei estava particularmente convencido de que os ocidentais apreciariam os jidaigeki exatamente por serem exóticos, embora correndo o risco de criar clichês que ao longo do tempo lesariam a imagem cinematográfica nipônica. Por isso, apesar dos ótimos gendaigeki desses anos, obras de diretores como Ozu e Naruse continuavam a serem endereçadas ao público de casa, ao passo que à Europa, eram enviados filmes de época colossais como A porta do inferno, no qual se pode suspeitar de uma tentativa de atender ao gosto não-japonês (Novielli, 2007: 147).

Mas qual teria sido o impacto de Rashomon em São Paulo?

No tempo de soldado raso me veio um faniquito diferente desses no meio da febre em que eu vivia entre mulheres, zona, sinuca e aprontagens de rapaz. De repelão e inteiriço, um amor pelas coisas do Japão. Judô, sakê. Pintura, gravura, desenho, hai-cais, tudo de uma mina, o filme Rashomon, de Akira Kurosawa, baseado em um conto, Dentro do bosque, de Ryonosuke Akutagawa ou na junção de duas histórias admiráveis do japonês. Desandei a ver coisas no bairro da Liberdade, naquele tempo nada badalado, não folclorizado em atração turística [...] Enfiava-me pelos restaurantes, lojas, academias de judô e tive, sim, camaradinhas judocas, educados, umas moças. Mas feras no tatami. Delicadeza das mulheres do Japão me tocava com suas manhas dissimuladas. Sonsas, sutis professoras. Freqüentei cada sábado, cada domingo, o Cine Niterói, na rua Galvão Bueno, e o São Joaquim [...] (João Antonio, 1986: 77).

Neste fragmento do artigo "Vibrações, Pulgueiros e "Ladrões de Bicicleta", publicado na revista Filme e Cultura (1986), o escritor paulista João Antônio rememora a sua aproximação tanto com as expressões artísticas japonesas quanto com o bairro da Liberdade, desencadeadas pela experiência de assistir ao filme Rashomon. Ele cita o Cine Niterói e o Cine Tokyo como os cinemas japoneses que passou a freqüentar com assiduidade. $\mathrm{O}$ contexto a que o escritor se refere é o da Liberdade na primeira metade dos anos 1950, época em que havia apenas dois cinemas japoneses em funcionamento e o bairro começava a aglutinar o comércio nikkei nas cercanias do Cine Niterói. A configuração da Liberdade como bairro turístico japonês viria depois, a partir do final da década de 1960 (Negawa, 2000).

Segundo Richie, as duas histórias de Akutagawa que serviram de ponto de partida para o roteiro de Rashomon seriam, por sua vez, baseadas em anedotas do período Heian (7941194). O filme recontaria a história de um marido e de sua esposa, atacados por um bandido. Durante o julgamento, cada personagem narra a sua versão do incidente: o bandido, a esposa violentada, o marido assassinado (através de um medium), e um lenhador, testemunha única e pouco confiável. No entanto, as versões apresentadas são tão variantes, que tanto o magistrado 
quanto os espectadores do tribunal são incapazes de decidir o que realmente aconteceu. $\mathrm{O}$ filme questionaria não apenas a verdade, mas a realidade em si mesma:

A história original de Akutagawa é sobre a verdade relativa, mas o filme de Kurosawa é sobre o tipo de realidade relativa que talvez apenas o cinema possa oferecer. Assistimos a cada versão da história, cada uma mais "real" que a outra [...] Com sua modernidade psicológica e seus questionamentos do pós-guerra, o filme foi uma recriação literal da história de Akutagawa. A aparente realidade de cada versão nos faz questionar a realidade das demais. A intenção original do autor foi anedótica, mas o filme é considerado agora um testemunho existencial contemporâneo - cada um de nós inventa a sua realidade pessoal (Richie, [2001] 2005: 138-139) [tradução do autor].

Esse aspecto do filme comentado por Richie em 2001, parece convergir com a opinião do crítico de cinema Jean Claude Bernardet a respeito de Rashomon, bem como sobre o motivo de sua atualidade e relevância para a reflexão contemporânea, mais de meio século depois de seu lançamento:

Eu lembro do Rashomon, mas eu não sei onde eu assisti. E Rashomon é um filme que eu considero até hoje marcante. Eu era menos anti-Kurosawa do que os outros. Mas, de vez em quando, eu continuo pensando no Rashomon porque no momento em que nós vivemos hoje, de questionamento do que seja ficção, do que seja realidade, o que não é realidade, o que não é ficção, eu acho que o Rashomon e o livro têm um lugar na discussão atual. Então eu continuo tendo muito afeto por esse filme.

Mas o que significaria ser menos anti-Kurosawa que os demais? Ao ser perguntado sobre o seu primeiro contato com o cinema japonês, Bernardet menciona o Tourist Bar, localizado próximo ao auditório do Museu de Arte Moderna (MAM), onde encontrava o cineasta Walter Hugo Khouri e o crítico de cinema Rubem Biáfora. Entusiastas do cinema japonês, os dois valorizariam obras de diretores como Ozu, Naruse e Mizoguchi, em detrimento dos filmes de Kurosawa, que seria considerado por eles, na época, um cineasta ocidentalizado e não-autêntico:

Nos anos 1950, o Rubem Biáfora, de O Estado de S. Paulo, e o Walter Hugo Khouri estavam bastante ligados, interessados em cinema japonês. Então, o mais provável é que eu tenha ido assistir a um filme japonês a partir das sugestões deles. Eu me encontrava com eles na praça Dom José Gaspar, no Tourist Bar. O Biáfora ia de vez em quando, e o Khouri estava bastante presente. Eu já tinha uma idéia bastante firme já do que era para eles o cinema japonês. E uma das coisas que nestes anos 1950 e 1960 eles recusavam era o Kurosawa, favorecendo Ozu, Naruse e Mizoguchi. Nitidamente ia neste sentido. O Kurosawa era considerado por eles como um cineasta muito influenciado pelo cinema ocidental, muito desejoso de satisfazer o público ocidental, enquanto os outros eram tidos como mais autenticamente japoneses. Uma outra possibilidade quanto ao meu contato com o cinema japonês pode ser o Rashomon, mas aí não seria especialmente na Liberdade. 
Em artigo publicado em 1997, Walter Hugo Khouri afirma ter sido fortemente marcado pelo "cinema intimista japonês", dramas contemporâneos de cineastas como Naruse, Ozu, Heinosuke Gosho e Hideo Ohba, que abordariam temas do cotidiano de pessoas de diversas classes sociais. $\mathrm{O}$ cineasta reconhece a influência dessas obras em seus filmes, produzidos a partir da década de 1970, e em $O$ quarto (1967), segundo filme dirigido por Rubem Biáfora. Esse tipo de cinema é contraposto por ele aos filmes de época, que seriam marcados pela presença de elementos típicos e exóticos, classificação que incluiria também os filmes de Mizoguchi. Para Khouri, a exibição de obras do cinema intimista japonês nas salas da Liberdade é o que conferiria singularidade à cidade de São Paulo, em relação aos outros grandes centros cinematográficos do mundo:

É importante notar que essa influência veio diretamente do contato dessas pessoas com as obras exibidas nos cinemas paulistanos, e não dos filmes que começavam a ganhar fama nos festivais internacionais a partir de 1950, como Rashomon e Os sete samurais, de Kurosawa, ou Oharu e Contos da lua vaga, de Mizoguchi, obras com forte presença de elementos exóticos e típicos, geralmente ambientadas em épocas passadas, os chamados filmes "de costume" ou "de samurai", com música, vestimentas, cenografia e outras características de períodos mais antigos, com personagens nobres, distanciados da temática e estrutura do cinema intimista mais autêntico, que tanto nos impressionava e ao qual não tinha acesso a maioria dos grandes centros cinematográficos do mundo, que recebiam sua dose de cinema nipônico diretamente de Veneza e Cannes. Nesse sentido, a cidade de São Paulo teve um grande privilégio e a fortuna de proporcionar aos seus cinéfilos a visão dessas obras-primas, já que era, e é, a maior cidade "japonesa” fora do Japão (Khouri, [1994] 1997: 138-139).

Heinosuke Gosho dirigiu 99 filmes ao longo de sua carreira, entre farsas, comédias, dramas familiares, melodramas românticos e dramas sociais (Richie, 2005). Donald Richie contrapõe a maneira como Mizoguchi constrói a atmosfera de seus filmes, por meio dos elementos gráficos da fotografia, pelos pontos de vista e movimentos de câmera, com o olhar de dramaturgo de Gosho, que faria da construção dos personagens seu material bruto. Outra maneira pela qual se criariam atmosferas nos filmes de Gosho seria pelo uso de numerosos close-ups e na montagem, onde se encadearia uma quantidade significativamente maior de planos em relação à média das produções da época (idem, 1971: 120-122). Richie identifica a influência de filmes estrangeiros apreciados por Gosho, como os de Ernst Lubitsch e Charles Chaplin, no desenvolvimento dessas características, identificadas já em Madamu to Nyobo (1931), o primeiro filmes sonoro de sucesso do Japão (Richie, 2005: 48).

Em seus filmes, Gosho criaria uma mistura eclética dos gêneros cinematográficos, infundindo emoções inesperadas às comédias. Disso resultaria o goshoísmo, termo usado pela crítica de cinema japonesa para designar um estilo de filme que faria o público rir e chorar ao mesmo tempo (idem, ibidem: 50). Ao contrário das obras de Ozu, Naruse e Mizoguchi, haveria 
nos filmes de Gosho um sentido de libertação (Richie, 1971: 124). No primeiro de seus quarenta livros sobre o cinema japonês, publicado no Japão em inglês, em 1959, Richie escreve: "Something has happened, there is a sense of release. The circumstances remain the same but the outlook has changed and there is room for optimism" (Richie; Anderson, 1959: 358). No livro O Cinema Japonês (1964), José Eduardo Marques de Oliveira atenta para a proeminência que linha "intimista" adquiriu no Brasil no período do pós-guerra, devido ao respeito suscitado pelos filmes de Ozu, Gosho, Ohba, entre outros:

A filosofia da arte de Gosho é simples: consiste em amar as pessoas, para poder recriá-las artisticamente como personagens. O "goshoísmo" é um estilo que foi definido como qualquer coisa que faz chorar e rir ao mesmo tempo, e que os japoneses chamam de "nakiwarai". As personagens de Gosho são todas inocentes: elas nunca têm consciência exata do que lhes está acontecendo, não sabem reagir às circunstâncias, ou não sabem contra o que estão lutando. Os seus shomingeki são levados para o nível da tragédia pessoal. Gosho acredita no valor da individualidade humana. E a tragédia tem sempre um ponto de liberação, um senso de otimismo final em que as circunstâncias podem permanecer as mesmas, mas o ângulo de visão pode mudar (Marques de Oliveira, 1964: 29).

Se as análises de Richie e de Oliveira acerca da obra cinematográfica de Heinosuke Gosho apresentam semelhanças entre si, o olhar de Jairo Ferreira, crítico de cinema do jornal São Paulo Shimbun, demarca uma diferenciação entre gerações, tanto em relação ao próprio Gosho quanto a outros grupos de freqüentadores não-nikkeis dos cinemas japoneses, como o de Rubem Biáfora e Walter Hugo Khouri:

Em cartaz no Esplanada, uma obra-prima: Mulher fatal, de Heinosuke Gosho. 65 anos de idade, 44 de cinema. Um dos expoentes da cine-gerontocracia. Inventor do "romantismo exacerbado". Para nós, da Geração Beatles, que já vivemos no futuro, Gosho é um velho gagá que nada nos diz. Mas por isso mesmo, uma personalidade admirável. Que respeitamos, embora com irreverência. [...] Estudamos a tradição. Amamos a tradição. Compreendemos a tradição. Mas para destruí-la com ódio e frieza. [...] Fita de exceção, louvável anti-consumo, Mulher fatal aí está cultuando o deus Fudo, curvando-se ao misticismo, resignando-se à miséria, auto-flagelando-se como alma penada num mundo estranho. Mas, ao contrário do genial Imamura, Gosho pactua com essa realidade. Mas em Gosho, o misticismo fatalista asfixia a platéia. [...] As gerações atuais compreenderão Mulher fatal, mas as gerações passadistas, que idolatram Gosho como clássico eterno (portanto reacionário), não nos compreenderão. Simplesmente porque não há diálogos com múmias (Ferreira, [1967b] 2006: 46).

O primeiro filme de Gosho exibido na cidade foi Ginza no Yanagi (1932), apresentado sem legendas, em 1938, no Cine Theatro São Paulo (Marques de Oliveira, 1964: 29). Um filme citado de forma recorrente por alguns dos freqüentadores das salas da Liberdade é $O$ corvo amarelo (Kiroi karasu, 1957). Em 1958, esse filme conquistou o prêmio norteamericano Globo de Ouro, na categoria de Melhor Filme Estrangeiro. No mesmo ano, Dante 
Ancona Lopes abriu o Cine Coral na rua Sete de Abril, considerado o primeiro "cinema de arte" de São Paulo e onde seria exibido o filme de Gosho ${ }^{43}$. As fontes divergem quanto à data de exibição do filme: segundo Tsuyoshi Mizumoto, presidente da Shochiku do Brasil, a partir de janeiro de 1959 O corvo amarelo teria sido exibido por 14 semanas no Cine Coral com lotação esgotada, seguindo depois para o Rio de Janeiro, onde permaneceria em cartaz por sete semanas (Mizumoto, 1986); em Cinema japonês (1964) consta que o filme teria sido exibido, no Cine Coral, em outubro de 1961; Futemma (1986: 79) afirma que em 1963 o filme teria permanecido por 13 semanas em cartaz na sala da rua Sete de Abril.

Jo Takahashi argumenta que o filme não foi exibido na Liberdade, mas nos cinemas fora do bairro. Ele atribui isto ao fato do filme ser uma produção independente, sem oportunidade, portanto, de ser exibido nas salas controladas pelas grandes produtoras. Após décadas dirigindo os shomingeki (dramas da classe-média baixa) para a Shochiku e depois de seu desligamento da Toho no pós-guerra, Gosho fundou o Studio 8, produtora de cinema na qual passou a desenvolver seus projetos. O corvo amarelo pertence a essa fase, mas nos anos 1960 dois de seus filmes seriam ainda exibidos no Cine Niterói e quatro no Cine Nippon. Como nos casos anteriores, a exibição do filme de 1957 numa sala não-japonesa parece ligarse mais à sua premiação num festival de prestígio internacional. E o que explicaria o sucesso do filme no Cine Coral? Talvez por abordar, de maneira inovadora ou educativa, um assunto pouco discutido na época, a subjetividade de uma criança frente aos problemas familiares:

$O$ corvo amarelo é importante na medida em que coloca problemas de pais e filhos desajustados pela guerra e, apesar de seu final simplista, chega a exemplificar de modo satisfatório o encontro de dúvidas no mundo interior infantil, por meio de criações artísticas. Tese moderna e fascinante que permitiu um filme muito bom até quase o final ingênuo e de concessão comercial (Marques de Oliveira, 1963: 36).

Tem um filme, que não é tão famoso, mas passou num circuito muito grande, fora do reduto da Liberdade. O filme se chamava $O$ corvo amarelo. Eu não tenho referências, mas é um filme muito educativo, porque mostrava uma série de problemas de família, que uma criança acaba denunciando nos desenhos que faz na escola. E a professora, preocupada, tenta investigar o que está acontecendo com o menino e começa a freqüentar a família dele. Ele é muito educativo neste sentido porque mostra a escola, a professora, numa preocupação muito grande de empatia com os familiares, os pais dos alunos (Jo Takahashi).

Em 1958, aos 15 anos de idade, o cineasta e crítico de cinema Alfredo Sternheim conheceu Khouri e Biáfora nas palestras promovidas pelo cineclube do Centro Dom Vital, na

\footnotetext{
43 "O Coral, no centro da cidade, se transforma em pouco tempo no ponto de encontro de uma platéia ávida por emoções cinematográficas menos convencionais. Lá são exibidos filmes de Antonioni, Fellini (A doce vida fica meses em cartaz), Os incompreendidos de Truffaut, $O$ ano passado em Marienbad, pautando a sua programação com títulos que os exibidores geralmente rejeitam sob o argumento de prejuízo certo" (Simões, 1986: 73).
} 
rua Barão de Itapetininga. Convidado por Hélio Furtado do Amaral, ele passa a escrever sobre cinema no Diário de Belo Horizonte. "Depois fui assistente do Khouri em A ilha [1963], e o Biáfora e o Khouri eram amigos, então a gente freqüentava o mesmo bar, o Tourist, na praça Dom José Gaspar”. Em março de 1963, Fernando Seplinski, segundo crítico de cinema do jornal $O$ Estado de S. Paulo, desentendeu-se com Biáfora, crítico principal, que convidou Alfredo para substituir Seplinski temporariamente. A parceria entre Biáfora e Sternheim na coluna dominical Indicações da semana se estenderia por quatro anos, de 1963 a 1967.

O primeiro filme japonês assistido por Sternheim foi $O$ homem do riquixá (1958) no Cine Picolino, em 1959, um ano após o filme ter conquistado o segundo Leão de Ouro de Veneza para o cinema japonês (Fig. 25). Segundo Massao Oshida, representante da Toho da América do Sul, esse filme teria sido lançado em abril de 1959 no Cine Marrocos, num evento patrocinado pelo Consulado Japonês e que teria contado com a presença de diversos críticos de cinema da cidade (Oshida, 1986). A sessão de estréia do filme teria sido precedida por uma palestra do crítico Francisco de Almeida Salles (Kobori, 1997). O comentário de Sternheim a respeito do impacto causado pelo filme remete à discussão sobre as imagens exóticas do Japão apresentadas em algumas obras:

Foi impactante. Pra mim foi, porque eu estava vendo um mundo que eu desconhecia. Por exemplo, o mundo do jerinquixá era uma coisa que para um paulistano de origem européia era uma novidade e era bonito. Depois que comecei a ver mais e mais filmes japoneses, e foi muito bacana me aprofundar na cultura, na ética japonesa, na ética dos samurais. Por exemplo, os filmes que eu via da Toei no Cine Niterói, os filmes do Tomo Uchida que era um dos diretores que eu mais amava, me puseram em contato com essa ética dos samurais.

Carlos Reichenbach enfatiza o caráter exótico de $O$ homem do riquixá, qualificando-o como "macumba para turista", ao mesmo tempo em que reconhece a importância do filme para a difusão do cinema japonês pelo mundo afora. Para além da pecha de cineasta ocidentalizado, Reichenbach define Hiroshi Inagaki como "um pau mandado", faltando em seus filmes certas qualidades discerníveis mesmo em outros filmes populares ou comerciais:

Acho que era uma espécie de filme bem comercial. Na década de 1950, eu tenho impressão que foi um filme essencial para conhecer o cinema japonês no mundo todo, muito mais do que os filmes do Kurosawa, que interessavam uma parcela muito específica, especialmente Rashomon que é um filme mais cabeça. Mas o filme que foi o cartão de visita do cinema japonês foi $O$ homem do riquixá, bem macumba para turista mesmo. [Tipo cultura exótica?] É, bota exótica nisto. [...] O Inagaki era o mais ocidentalizado dos diretores, fazia aqueles filmes que a gente tinha nojo [risos]. Mas foi fundamental para o conhecimento do cinema japonês. [Para o público leigo, não para vocês.] Naquele momento não, acho que tem essa coisa da radicalização que você começa a ficar com pruridos contra o cinema mais macumba para turista, como a gente dizia. Precisa também ver que não é isso que cria a diferença entre o filme bom e ruim. Vale dizer que os filmes do Inagaki são incompetentes. 
Não é o exemplo do grande artesão, é um pau mandado. Não é como o Noboru Nakamura, que é diretor de filmes populares, comerciais, puta tesão! Ver filmes do Nakamura é uma aula de cinema. Você pode achar o filme menor, mas tem um artesão lá, um mestre ${ }^{44}$.

\subsection{Kurosawanas}

Reichenbach, no entanto, revê criticamente essa tendência de depreciar os filmes japoneses que dialogassem com outras cinematografias, o que levaria a rotular os diretores dessas obras de ocidentalizados ou de não-autênticos. Desde o sucesso internacional de Rashomon, esse estigma recairia com maior peso sobre Akira Kurosawa, gerando aquelas posições mais ou menos anti-Kurosawa. Para ele, isso seria uma forma de preconceito ou um efeito da sofisticação dos grupos de apreciadores de cinema japonês na época:

$\mathrm{Na}$ verdade eu fui perder certos preconceitos contra o cinema japonês ocidentalizado, posteriormente. Eu não gostava de Kurosawa, achava ele um vendido. Olha que coisa louca! Hoje eu lavo a boca porque eu falava isso. E é gozado, porque o filme do Kurosawa que eu mais gostei na minha vida é adaptado de um romance policial americano, do Ed McBain, Céu e inferno. Ele pegou um dos livros do $87^{\circ}$ distrito policial, que era um livro que eu lia. [...] Eu virei fã de novo do Kurosawa: "Pô, esse cara gosta de McBain, deve ser bom pra caralho, porque eu gosto porra!" [risos] Mas eu me lembro que havia esse preconceito de achar que ele era um cineasta ocidentalizado. A gente chegou num ponto de sofisticação tamanha que qualquer filme japonês que tivesse diálogo com o cinema americano você botava o pé atrás.

Se Rashomon e Os sete samurais são filmes de Kurosawa nos quais Walter Hugo Khouri observa a presença de elementos exóticos ou típicos, justamente por serem ambientados no passado, isso não poderia ser dito a respeito dos filmes de ambientação contemporânea do cineasta, como é o caso de Céu e inferno (Tengoku to jigoku, 1963) e de outros, lembrados por Sedi Hirano e Marina Narahara. Viver (Ikiru, 1952) é tão significativo para Hirano, a ponto de ele rever o filme diversas vezes (Fig. 26). Richie comenta que o filme é simultaneamente uma exploração existencial (o homem é apenas aquilo que realiza) e uma devastadora condenação da burocracia (Richie, 2005: 275). Esses dois aspectos aparecem também na interpretação de Hirano, que indica ainda um terceiro - o sentido de sonho e de utopia, que estaria presente nos bons filmes:

\footnotetext{
${ }^{44}$ Essa definição de Hiroshi Inagaki como "um pau mandado" aproxima-se da conclusão de João Ribeiro acerca dos filmes do cineasta, no livro O Filme Japonês, publicado em 1963 pelo Grupo de Estudos Fílmicos: "A conclusão mais plausível que se pode obter na análise de seus filmes, é que Inagaki está satisfeito em ser um apenas um diretor que realiza de acordo com os desígnios superiores da companhia para a qual trabalha, não tendo preocupações mais sérias, por isso recebendo o cognome de 'o príncipe dos diretores', honroso na consideração do fator publicidade, mas mentiroso na consideração do fator estético" (Ribeiro, 1963: 39).
} 
Um filme do Kurosawa que eu adoro assistir e assisti duas, três, quatro vezes, e tenho até o $d v d$, é Viver. Eu acho esse filme lindo. Viver é uma crítica radical à burocracia. Um homem que descobre ter câncer decide buscar o sentido da vida. Começa a freqüentar cabarés, bares, e de repente está voltando de madrugada, e vê uma operária feliz. Ele quer saber a razão de sua felicidade. Aí ela tira da bolsa um boneco, dá corda e ele começa a dançar. Ela diz: - Eu sou feliz porque eu fabrico isso, que faz com que as crianças fiquem contentes. De repente dá um estalo, ele se lembra que tinha cinco senhoras que haviam encaminhado um pedido pra construir um parque infantil e ele, como burocrata, tinha engavetado. E esse burocrata sem sensibilidade, sem alma, resolve construir alguma coisa para as crianças. Ele fica horas esperando na porta dos outros burocratas pra conseguir uma autorização aqui e outra ali. E o filme termina com ele sentado num balanço, cantando aquela canção Gôndola, que diz que a vida é curta e depois as pessoas percebem que ele morreu feliz. Porque o filme mostra que o burocrata é um morto-vivo, que no final adquire vida, descobre o sentido da vida. Então eu acho que em termos de mensagem revela a visão de uma pessoa de esquerda: vamos trabalhar com a consciência dos seres humanos, vamos despertar as consciências. [...] O bom filme tem a idéia de utopia. Se uma pessoa é morto-vivo, não tem o sentido de missão. Mas alguns filmes mostram que há um momento na vida em que a pessoa acaba descobrindo a utopia, o sentido de missão, e que é importante sonhar. Viver é exatamente isso, tem esse tipo de mensagem.

Marina Narahara descreve o impacto dos filmes $O$ homem mau dorme bem (Warui yatsu hodo yoku nemuru, 1960) e Derzu Uzala (1975). Ela caracteriza o primeiro como um filme que romperia com certas convenções narrativas e morais do gênero policial (a recompensa da virtude e a punição do crime), e que, por isso mesmo seria maravilhoso, apesar da raiva suscitada por seu enredo. Um indício da emoção provocada por Derzu Uzala em Marina é a lembrança precisa da sala de cinema em que o filme foi assistido:

No Cine Jóia passavam os filmes do Toshiro Mifune e também os de Akira Kurosawa. Kurosawa é maravilhoso! Akahige, Barba ruiva é maravilhoso! E eu adorei aquele filme $O$ homem mau dorme bem. Um homem mau que se dá bem no final. É completamente diferente dos filmes normais, que sempre são água com açúcar, sempre é o mocinho que ganha, esse não, é um político, que faz as dele, que faz sujeiras e no final, eu me lembro muito bem, ele está no telefone falando que deu tudo certo e tal e acaba com o bandido que se dá bem. Dá raiva, mas é a realidade, esse filme é maravilhoso. E Derzu Uzala. Nossa, é maravilhoso. Ele foi para a Rússia inclusive fazer a filmagem, ele foi escolher o local para a filmar, e ele achou lá na Rússia. Derzu Uzala foi tão emocionante para mim que eu assisti de novo. [...] O filme passou no Cine Arouche onde eu fui assistir. Derzu Uzala nem passou na Liberdade.

Cláudio Willer argumenta que os filmes de Kurosawa eram exibidos no "circuito normal", isto é, nos cinemas fora da Liberdade, como o caso de Yojimbo (1961), exibido no Cine Scala em 1962, assim como O homem mau dorme bem, lançado no mesmo cinema meses depois, em fevereiro de 1963 (Ohno, 1964: 65). Alfredo Sternheim relembra dessa sala como um cinema de arte localizado na rua Aurora, próximo à praça da República. Tanto o Cine Jóia quanto o Cine Scala pertenciam à empresa Serrador, de modo que quando havia mais de uma cópia do filme a Toho conseguia exibi-la nesse cinema. Num dia em que estava programado 
um filme japonês, Sternheim encontrou o Cine Scala em chamas. O incêndio, que não fez vítimas, é descrito por ele como belo, “[...] parecia coisa de cinema japonês".

Dos filmes de Kurosawa, Sternheim destaca justamente uma adaptação de uma peça de Shakespeare: "Kurosawa era o medalhão do cinema japonês, por causa de Rashomon e de $O s$ sete samurais, mas o filme que gostei muito dele foi Trono manchado de sangue [1957], que era versão japonesa de Macbeth, com Toshiro Mifune e Isuzu Yamada, uma atriz fantástica". A formação literária shakespeariana de Kurosawa é valorizada também por Willer. Ele formula uma interpretação das objeções levantada contra o cineasta no Japão, que teriam como causa a crítica dos valores e das perspectivas vigentes, como a desmistificação do mundo dos samurais, além da presença da sátira e do humor em filmes como Sanjuro (Tsubaki Sanjuro, 1962) e Os sete samurais:

\begin{abstract}
Agora mesmo o Kurosawa já fazia a sátira. No Kurosawa tem uma crítica, porque Sanjuro é completamente diferente. A visão política e de mundo já é outra. Quer dizer, tem humor e há uma desmistificação daquele mundo do samurai, mesmo em Os sete samurais, que abriu o campo para os outros. Talvez por isso que tenha essa idiossincrasia do Kurosawa ser criticado no Japão, não é? É que o enfoque dele era outro. Achavam que ele era ocidentalizado. Não era. Era inteligente. Kurosawa sempre foi um cineasta inteligente. E com essa bela formação literária, um shakespeariano.
\end{abstract}

As reflexões de Marina Narahara e de Cláudio Willer aproximam-se da interpretação da obra de Akira Kurosawa no primeiro livro publicado em língua inglesa sobre o cinema japonês. Em 1959, Donald Richie e Joseph Anderson descrevem Keisuke Kinoshita e Kurosawa como cineastas que afirmavam o novo humanismo do pós-guerra, mostrando, ao mesmo tempo, interesse em integrar elementos de estilos cinematográficos estrangeiros ao cinema japonês por meio de experimentos técnicos (Richie; Anderson, 1959: 181-182).

Para eles, o humanismo de Kurosawa atingiria o seu ponto mais alto em Viver. O trabalho de Kurosawa, junto com o de Kinoshita e o de Tadashi Imai, representaria uma quebra na tradição do filme japonês. No caso de Kurosawa, seria uma quebra a partir da tradição, uma vez que este cineasta teria sistematicamente se recusado a fazer o tipo de filme esperado. Ele teria confundido os críticos e, por vezes, as audiências, ao negar a filosofia predominante do cinema japonês, a produção de filmes em série a partir de fórmulas testadas, indo além dos confinamentos aceitos da linguagem cinematográfica no país. A experimentação contínua o levaria a modificar seu próprio estilo a cada novo filme, aborrecendo os críticos que preferiam que ele voltasse ao estilo do filme anterior. Essas teriam sido algumas das razões pelas quais alguns setores da crítica de cinema japonesa passaram a chamá-lo de ocidentalizado, ou de "o menos japonês dos cineastas" (idem, ibidem: 376). 
Os depoimentos aqui apresentados, no entanto, parecem indicar que rotular Kurosawa de cineasta ocidentalizado ou não-autêntico adquiriu um significado específico em São Paulo, diferente do observado em relação aos críticos de cinema japoneses. O diálogo com outras cinematografias não seria aqui um critério absoluto, pois se Khouri contrapõe o intimismo autêntico dos filmes de Gosho ao exotismo dos filmes de Kurosawa, observou-se como o primeiro forjou seu estilo narrativo num intenso diálogo com filmes norte-americanos, com a conseqüente presença em seus filmes de muitos close-ups e de uma quantidade maior de planos que a média dos filmes japoneses da época.

Como observado nos diversos exemplos, a estratégia adotada pelos representantes das companhias cinematográficas japonesas em São Paulo foi a de promover a exibição dos filmes premiados internacionalmente em cinemas fora da Liberdade, isto é, nas salas da Cinelândia (Broadway, Rosário, Ipiranga, Marrocos) ou nas do circuito de cinema de arte (Coral, Scala), com a expectativa de reprodução local do sucesso internacional alcançado por esses filmes. Kurosawa foi o primeiro cineasta japonês conhecido no Ocidente, o que não seria diferente para a maior parte do público paulistano de cinema dos anos 1950. Mas, a medida em que seus filmes foram se tornando populares por toda parte, rejeitá-los como ocidentalizados virou um sinal de distinção, um marcador de diferença dos grupos de “iniciados”, isto é, do público nãonikkei que passou a freqüentar as salas de cinema da Liberdade, e que, dessa forma, teve a oportunidade de conhecer muito mais do cinema japonês do que os "filmes de festivais".

Já nos anos 1980, Cláudio Willer assistiu ao filme Ran (1985) cinco vezes no cinema e outras cinco em vídeo e $d v d$. Numa relação dos melhores filmes do cinema mundial, ele colocaria o filme no topo da lista, junto com Kagemusha (1980). Kurosawa é o cineasta mais citado pelos freqüentadores dos cinemas da Liberdade que concederam depoimentos para esta pesquisa, assim como de nenhum outro realizador tantos filmes foram comentados. Ainda que na época parte dos espectadores afirmasse o contrário, desde 1951, com a exibição do primeiro filme dirigido por Kurosawa no Cine São Francisco [A vida de um lutador de judô (Sugata Sanshiro, 1943)], seus filmes foram apreciados com entusiasmo cada vez maior em São Paulo.

\subsection{Filmes de época e filmes de samurai}

Os sete samurais (Shichinin no samurai, 1954), dirigido por Kurosawa, é um dos filmes mais citados por alguns dos freqüentadores dos cinemas da Liberdade (Fig. 27). Donald Richie estava no Japão pela segunda vez na época do lançamento do filme, comparecendo a sua estréia. Ele afirma ter sido um dos poucos a assistir à versão integral, uma vez que a Toho 
reduziria em muito a duração do filme. Ao escrever sobre o lançamento do filme em São Paulo, em 1956, Francisco de Almeida Salles fala dos cortes impostos à obra do ponto de vista do espectador que nota descontinuidades narrativas e incongruências entre partes do filme:

Isso aconteceu no dia 26 de abril [de 1954], no auditório Nichigeki, o melhor cinema da Toho. Kurosawa tinha ultrapassado tanto o orçamento que a companhia decidiu explorar o filme, promovendo uma estréia de gala, cheia de estrelas e depois reduzindo drasticamente o filme (200 minutos no original) para as exibições locais. Fiz parte desse público privilegiado que viu o filme inteiro - os outros tiveram que esperar trinta anos até que razões comerciais persuadissem a Toho a reinserir os cortes e fazer cópias novas (Richie, 1996: 69).

A fita compreende três partes bem distintas: o contrato dos samurais para a defesa da aldeia, o preparo para a luta e finalmente, a luta. [...] A versão aqui exibida veio mutilada do Japão. Parece que o próprio Kurosawa teve que cortar impiedosamente cerca de uma hora de projeção, para adaptar a fita à exibição comercial. Nota-se, realmente, que a primeira parte, aliás, fundamental para a apresentação e a fixação dos temperamentos dos samurais, não tem a fluência e a minúcia das outras duas (Almeida Salles, [1956] 1988: 185).

$\mathrm{Na}$ época em que assistiu ao filme, Sedi Hirano, professor titular do Departamento de Sociologia da Universidade de São Paulo, teria se impressionado com a temática social abordada por Kurosawa, que, como visto, ele considera um cineasta comunista, de esquerda. Hirano ingressou na militância política ainda na época de estudante do ginásio. O engajamento político de esquerda atribuído a certos filmes e cineastas, e que mobilizava a atenção dos estudantes cinéfilos nas décadas de 1950 e 1960, constituiu para ele um critério de avaliação das obras. Há, no entanto, um outro olhar sobre o filme, motivado pela leitura recente de Confúcio e por sua formação de sociólogo, em que ele contrapõe as forças do indivíduo com as do coletivo:

Eu fiquei impressionado com Os sete samurais, porque para sete pessoas se juntarem para defender os camponeses, não tem um tema mais social que esse. [...] Atualmente eu estou lendo as frases de Confúcio. Essa idéia de benevolência, de grupo, de que a pessoa não é um indivíduo, como no caso da cultura ocidental, mas é forte dentro do grupo. Os sete samurais é o exemplo. O despertar da comunidade para o problema da proteção como um problema de todos. Os samurais vieram porque a comunidade vivia apavorada, com medo. Mas eles não podem ficar contratando os samurais sempre. Então eles começam a se dar conta do que uma comunidade unida, armada e adestrada é capaz.

Richie (1982) argumenta que o passado coletivo seria tão vital no Japão quanto o passado individual o é para os ocidentais. Em sua reflexão há o reconhecimento de elementos presentes universalmente em qualquer filme de época: a idealização romântica do passado e a projeção de idéias, questões e valores contemporâneos nele, isto é, o filme histórico diria sempre mais sobre a época em que foi feito do que a respeito da época a que se refere: 
[...] Notamo-lo com particular acuidade nos filmes, o que é normal, porque um filme lida sempre com o presente histórico. Apesar de o Japão ter a sua quota de romantismo e, nessa medida, falsa evocação do passado, os seus melhores filmes históricos são excelentes precisamente porque aí tudo é presente: o passado torna-se real na medida em que a única realidade é o instante presente. O que está em jogo em Os sete samurais, de Kurosawa, A vida de Oharu, de Mizoguchi, Harakiri, de Kobayashi, ou Duplo suicídio de Shinoda, é sempre, para os seus argumentistas e realizadores, o presente. O realismo dessas encenações em nada difere do realismo com que se pode encenar um drama contemporâneo, e isto pura e simplesmente porque, para um japonês com o seu sentido peculiar da história, as duas coisas são precisamente a mesma (Richie, 1982: 5).

Ao refletir sobre as características filme histórico japonês, Tadao Sato observa que, ao contrário de seus equivalentes europeus ou norte-americanos, os filmes japoneses raramente focalizam a vida de grandes monarcas, estadistas ou conquistadores e a resistência que lhes é oposta. O objetivo dos filmes históricos japoneses seria o de interpenetrar o pensamento dos mortos, por isso eles estariam povoados de pessoas que morreram deixando ainda vivo o seu rancor. "Os japoneses acreditam que aqueles que morreram tragicamente deixaram atrás de si um intenso sentimento de rancor; e que nós mortais, estamos sujeitos a sua maldição, e que devem ser consolados pela veneração" (Sato, 1982: 3).

Para Sato, isso estaria relacionado ao culto dos antepassados, centro gravitacional da religiosidade japonesa na qual se enraizaria o cinema produzido no país. Ele argumenta que os japoneses se empenhariam em permanecerem fiéis às esperanças e ambições transmitidas aos vivos pelos mortos, isto é, a vontade de corresponder àquilo que os mortos esperam deles seria fundamental para a sua atitude moral. As histórias de fantasmas, as tragédias e os estudos históricos seriam os veículos preferenciais para a reflexão acerca do rancor dos mortos:

A principal característica da tragédia japonesa é a ênfase dada ao rancor póstumo de uma pessoa que morreu de morte trágica. $O$ intendente Sansho e $O s \quad 47$ ronin ilustram isso. Nenhum deles é uma simples história de vingança, que chega ao fim quando se faz justiça, quando aquele que possui o rancor abate o seu inimigo. Nestas histórias japonesas, o clímax chega quando o vingador entra em harmonia com a pessoa que morreu tendo deixado o seu rancor insaciado. [...] Essa sensibilidade ao rancor dos mortos é encontrada não só nas histórias clássicas, mas também em filmes de ambiente contemporâneo: Golpe de estado, Fogo na planície, Guerra e humanidade, Filhos de Hiroshima e Uma tragédia japonesa são exemplos. Mesmo num filme moderno como Noite e névoa sobre o Japão, de Oshima, a chave das complexas relações entre os dois grupos antagonistas está no seu grau de simpatia para com o pensamento do seu antigo companheiro que se suicidou (Sato, 1982: 3-4).

A essa interpretação dos filmes históricos proposta por Sato parece corresponder lembrança de Olga Futemma a respeito de Contos da lua vaga depois da chuva (Ugetsu Monogatari, 1953), um de seus filmes japoneses preferidos: 
Em Contos da lua vaga [a presença de] fantasmas, mas que estão ainda na ativa pela necessidade de amor. A moça não conheceu o amor, como pode morrer? Então ela volta, com a proteção da ama dela. Essa idéia do fantasma que interage numa chave de busca do amor eu nunca tinha visto, pra mim fantasma era uma coisa pra te assustar, pra te fazer mal, então é muito diferente. [Há um segundo fantasma que é a mulher dele, que o recebe de noite, quando ele volta à aldeia]. Ela está lá, mexendo um caldeirão, mas no dia seguinte só está o filho. Ele vai à sepultura render as homenagens para a mulher, e aí tem um som muito agudo, que é típico da música clássica japonesa - tiim - e o filme acaba. A primeira vez que eu vi o filme pensei: mas que coisa bela! É um dos filmes japoneses que eu mais gosto.

Olga fala do filme da perspectiva da personagem feminina, Wakasa, a misteriosa dama aristocrática que compra as peças de cerâmica do oleiro Genjuro, enfeitiça-o, e faz dele seu amante, realizando, na condição de fantasma, sentimentos e desejos insaciados pela morte (Fig. 28). Já Sedi Hirano descreve o filme sob o ponto de vista dos personagens masculinos, Genjuro e seu cunhado Tobei, relacionando a construção do enredo do filme com aspectos do imaginário social da época - a obstinada aspiração de um camponês em tornar-se um samurai, ou os sonhos de fama e riqueza de um oleiro pobre do meio rural:

Muitas vezes a pessoa que se torna senhor da guerra pode ter uma origem camponesa. Tem
aquele filme famoso, Contos da lua vaga depois da chuva. Não tem o camponês que quer
ser samurai de tudo quanto é jeito? Ele abandona a mulher e vai embora, ou o ceramista que
fazia cerâmicas maravilhosas e que também vai atrás de uma miragem. Acho que essas
coisas fazem parte do imaginário. Se no filme aparece esse tipo de imaginário, é porque
estava povoando a cabeça da população, então, de uma forma ou de outra ele existia. Contos
da lua vaga é a alimentação do sonho, de uma utopia, só que na verdade, o cara perde a
mulher, perde várias coisas porque tenta transformar o imaginário em realidade. E a pessoa
passa a se apaixonar por uma mulher fantasma, uma princesa fantasma.

O primeiro filme japonês assistido pelo escritor Cláudio Willer foi um dos episódios da trilogia A espada diabólica (Daibosatsu Tôge, 1957-1959), exibidos no Cine Niterói de 1958 a 1960. Ele já conhecia o bairro da Liberdade por intermédio de Rodolfo Geisel, um colega do Colégio Dante Alighieri e também amigo de Carlos Reichenbach, que tinha contato com os nikkeis por praticar judô e karatê no bairro. Aos 18 anos, Willer passou a frequientar o cursinho pré-vestibular Anglo Latino, localizado na rua Tamandaré. Numa tarde, ao matar uma das aulas e flanar pelas ruas do bairro, ele desceu a ladeira do cursinho, virou à direita na rua Galvão Bueno e entrou no Cine Niterói. A experiência de assistir ao filme de Tomu Uchida nessa sala o impressionou de tal maneira, que ele passou a acompanhar a programação de cinema japonês e a avisar seus amigos. Na década de 1960, Willer conviveu com um grupo de poetas paulistanos do qual faziam parte Roberto Piva, Rodrigo de Haro, Antônio Fernando 
de Franceschi, entre outros, que freqüentava os cinemas, restaurantes e bares da Liberdade. Em 2007, ele escreve sobre as impressões suscitadas pelo episódio assistido ${ }^{45}$ :

Em 1959, aproveitava o interregno entre terminar o colégio e cair na vida para flanar pelo bairro da Liberdade. Passando em frente ao Cine Niterói na Galvão Bueno [no lugar, hoje, um viaduto sobre a 23 de Maio], resolvi entrar. Na tela, uma colorida profusão de espadas e roupas de samurai. Uma explosão, e o samurai que estava matando os adversários que o cercavam ficava cego, mas não incapacitado de lutar. Fim do filme - da primeira parte, logo soube. Que porta de entrada para o cinema japonês o acaso havia me oferecido: o começo da trilogia A espada diabólica, de Tomu Uchida (Willer, 2007: 74).

Indagado sobre o que teria chamado sua atenção no filme, o escritor menciona diversas razões: o fascínio exercido pela estética diferente e pela apresentação de um outro mundo; a qualidade do cineasta Tomu Uchida; a abordagem da ética da violência; o modo hierático da interpretação dos atores, isto é, a rigidez e a codificação dos gestos e das posturas corporais; além da própria impossibilidade da história: o protagonista fica cego com uma explosão ao final do primeiro episódio, sendo aniquilado apenas no desfecho do último filme.

Se o gosto pelo cinema japonês de Willer e seus amigos parece relacionar-se ora com o exotismo da realidade apresentada, ora com o esteticismo, ou seja, com a contemplação da beleza visual dos filmes ${ }^{46}$, Sedi Hirano e José Fioroni Rodrigues chamam à atenção para outro aspecto narrado nessa mesma obra: o processo de desumanização vivenciado pelo protagonista ao longo da trama, e, no desfecho, a recuperação de sua humanidade. O aperfeiçoamento nas artes da luta faz com que o personagem seja comparado por Hirano e Rodrigues a um demônio, porém, a apresentação de imagens relacionadas ao budismo indicaria a possibilidade de redenção:

Fiquei muito impressionado com o filme Espada diabólica, do Tomu Uchida. Ele começa como espadachim, um ser humano com todas as fraquezas, amores, pecados e decepções. Eu me lembro bem de uma cena em que uma senhora vai falar com ele, para que poupasse o marido. Ele diz que um espadachim tem que aperfeiçoar a arte da guerra e da luta e que não pode ter certos tipos de sentimentos, porque isso faria com que ele morresse ao invés do outro. O filme é bonito porque mostra como ele se transforma num diabo, perde sua sensibilidade e vira uma máquina de luta. E leva isso a tal perfeição, que naquela luta famosa que ocorre numa ponte com fogo, ele praticamente encarna a figura do diabo. Então, pra ser um grande espadachim, o homem vai anestesiando seus sentimentos, vai se desumanizando. O filme mostra esse processo de desumanização (Sedi Hirano).

\footnotetext{
${ }^{45}$ No livro $O$ cinema japonês (Ohno, 1964: 37) consta que o primeiro filme da série teria sido exibido no Cine Niterói em 1958, o segundo em julho de 1959 e o último episódio em junho de 1960. Se essas datas estiverem corretas, talvez o primeiro filme japonês assistido por Willer tenha sido o segundo episódio da série.

${ }^{46}$ Isto é o que se deduz dos comentários de Cláudio Willer acerca do filme de Uchida. No depoimento concedido ao autor, ele afirma: "Bom, a gente curtia por esteticismo. Eu, Piva e os outros amigos. Era realmente a beleza visual, o hieratismo, as qualidades que eu observei. Era uma visão externa e formal".
} 
Da Toei [...] o primeiro nome é Tomu Uchida que, com a trilogia Espada diabólica, descreve a odisséia de um samurai que vivia pela espada e para a espada e os males que daí advieram. Uma descida ao inferno do sofrimento pela tendência do homem para o mal, ferindo os outros e a si próprio, tal como um demônio que faz sofrer e sofre, que tortura e é torturado. Se poucas vezes o demonismo foi visto na tela com tal intensidade, por outro lado também era evidente o sentido de recuperação humana. As cenas iniciais da apresentação, com a pintura de motivos búdicos, mostrando ao alto as divindades e descendo até as mais cruentas torturas infernais, simbolizavam a concepção oriental de que a vida é um caminho, uma via de aperfeiçoamento espiritual através dos males e sofrimentos. E no final, em superposição a essa pintura, aparecia o espadachim elevando-se, reabilitado pela dor e pelo fim próximo, esquecendo a espada e clamando pelo filho, e readquirindo a sua condição humana diante da morte (Rodrigues, 1995: 168).

Em 1961 a Toei lançou o primeiro episódio de Miyamoto Musashi (1961-1965), série de cinco filmes dirigidos por Tomu Uchida e exibidos em São Paulo no Cine Niterói, entre os anos 1961 e 1966 (Fig. 29). Os filmes que integram essa série são comentados pela maioria dos freqüentadores dos cinemas da Liberdade que concederam depoimentos para esta pesquisa, ou seja, no quadro das lembranças de cinema dessas pessoas esses filmes são os mais recorrentes, sendo também apontados como uma das séries de maior sucesso de público na trajetória do Cine Niterói (Kobayashi, 2005: 27).

Em contraste com a importância atribuída à série de Uchida pelos espectadores de São Paulo, ela não é sequer mencionada em compêndios de história do cinema japonês: no livro Japanese cinema (1971), o único filme deste diretor citado por Donald Richie é Terra (Tsuchi, 1939), assim como a única versão de Musashi comentada por ele é a de Hiroshi Inagaki; o mesmo ocorre trinta anos depois, no livro A hundred years of Japanese Film, em que Richie apresenta a ficha técnica da trilogia de Inagaki e não faz menção alguma à versão de Uchida; dos filmes deste cineasta ele observa a influência do expressionismo nas primeiras obras, a sátira social em A living puppet (Ikeru ningyo, 1929), a aproximação com o film noir em Police (Keisatsukan, 1933) e com o gênero documental em Terra (Tsuchi), além da crítica social em seus últimos filmes, como em Hunger straits (Kiga kaikyo, 1965) (Richie, 2005: 86); o mesmo fato se repete no livro A história do cinema japonês, em que Maria Roberta Novielli analisa a versão de Inagaki da história de Musashi sem mencionar a série de Uchida, dele destacando Uma boneca viva (Ikeru ningyo, 1929) e quatro filmes realizados de 1936 a 1939, dentre os quais Terra (Tsuchi) (Novielli, 2007: 82).

No livro The samurai film, publicado em 1977, Alain Silver escreve sobre as diferenças entre essas versões cinematográficas do romance de Yoshikawa, e em relação a uma terceira, dirigida por Yasuo Kohata (Miyamoto Musashi, 1954) para a Toei, que ele 
prioriza em sua análise devido à abordagem amoral e ao humor sarcástico presentes nessa versão, antecipando características observáveis em Yojimbo, dirigido por Kurosawa em 1961:

As imagens fílmicas de Musashi neste período pode ser a do nobre herói buscando o caminho verdadeiro, como na versão de três partes da Toho dirigida por Hiroshi Inagaki e intitulada simplesmente como Samurai, ou a da rebeldia sem causa e da juventude confusa na versão de cinco partes de Tomu Uchida para a Toei, ou ainda a imagem amoral e oportunista, como na primeira versão da Toei dirigida por Yasuo Kohata (Silver, [1977] 1983: 96) [tradução do autor].

Richie comenta que ao realizar Miyamoto Musashi, Inagaki estaria interessado no passado como chave para o presente, isto é, Musashi não seria um herói vaidoso e inconseqüente [mindless clotheshorse], mas um homem moderno (Richie, 1971: 21). Dos freqüentares dos cinemas da Liberdade que citaram as adaptações de Musashi, o único a mencionar a versão de Inagaki foi Cláudio Willer, que assistiu à trilogia da Toho logo após o impacto de A espada diabólica. Para ele, essa versão se destacaria pela beleza plástica contida na composição dos planos, na luminosidade da fotografia, no ritmo da montagem e na interpretação dos atores (Fig. 30):

Puxando mais para o esteticismo, quer dizer, assim como Kurosawa, Inagaki era um admirável artista plástico em cinema, a qualidade da fotografia e de imagem, o detalhe, a luz, a luminosidade, quer dizer, a qualidade visual combinada ao ritmo lento, aquele hieratismo oriental que sempre impressionou também.

E o que dizem os espectadores de cinema de São Paulo a respeito da série de Tomu Uchida? A rebeldia do personagem, mencionada por Alain Silver, reaparece na análise de Rodrigues, que aponta também para uma tendência anticlimática no desenvolvimento da narrativa, decorrente dos questionamentos existenciais do protagonista e de sua incessante busca pelo aperfeiçoamento espiritual:

De Uchida ainda tivemos outros grandes filmes [...], principalmente Miyamoto Musashi, em cinco épocas, em que o famoso espadachim surgia sempre indagando a causa dos duelos e o sensabor de suas vitórias; procurando aperfeiçoar-se espiritualmente e sempre insatisfeito, empenhado numa incessante busca existencial de valores. Mas, ao final, sem encontrar senão a incerteza, Musashi, após mais uma memorável vitória, parte amargurado, mas em busca de desafio - sabendo da inutilidade do esforço, mas o fazendo sempre num ato de revolta, num surdo rilhar de dentes contra o destino, numa afirmação de luta: o único valor possível ao homem (Rodrigues, 1995: 168).

Silver argumenta que ao contrário de Zatoichi, Miyamoto Musashi não é um personagem ficcional. No entanto, assim como os cavaleiros medievais europeus ou como os pistoleiros do oeste norte-americano, seria difícil separar o personagem histórico dos exageros 
e embelezamentos da lenda. O Musashi real nasceu em 1584, começando sua carreira aos 13 anos, e, após participar da batalha de Sekigahara, em que Ieyasu Tokugawa ascendeu ao poder tornando-se shogun, ele se dedicaria ao aperfeiçoamento do estilo das duas espadas (Enmyoryu e Niten-ryu) ao longo de sessenta duelos travados. Ele morreu a serviço do lorde Tadotoshi Hosokawa em 1645 e foi enterrado em Kyushu. Esses seriam os fatos da vida de Musashi.

A despeito de toda a violência e pragmatismo associados ao crescimento de sua fama no início da Era Tokugawa, a reputação de Musashi para muitas pessoas repousaria menos em sua estatura como espadachim do que como artista e seguidor do zen (Silver, [1977] 1983: 94). Esse aspecto parece relacionar-se tanto com as idéias de ascese e hieratismo evocadas por Willer, quanto com o relato de Gonçalves sobre a experiência de assistir ao filme e identificarse com seu protagonista, deflagradora de sua aproximação com o budismo:

Vamos voltar ao Miyamoto Musashi, tanto o de Inagaki quanto o de Uchida. É claro que é idealização, mas a vida dele é apresentada como uma ascese, como uma espécie de elevação búdica. Nos dois filmes mostra-se o aprimoramento, ele também fazendo o ukiyo-e $e^{47}$, desenvolvendo-se artisticamente, então [há] essa idéia de ascese, de transformação interior. E o interessante é o modo como isso é trazido para a tela, diferente do desenvolvimento de um western, em que o foco recai numa luta entre o bem e o mal, e não numa filosofia (Cláudio Willer).

Você se identificar com os personagens, por exemplo, quem adorava filmes de samurai, identificar-se com o Musashi é uma experiência forte. [...] O filme que me marcou muito mesmo naquela época foi a série Miyamoto Musashi, do Tomu Uchida. A percepção que eu tinha é que aqueles filmes conseguiam transmitir alguma coisa de fundamental a respeito do alicerce espiritual da cultura japonesa. Em grande parte estes filmes me motivaram muito a caminhar em direção ao budismo (Ricardo Gonçalves).

As lembranças de Marina Narahara e de Jo Takahashi a respeito da série apontam para aspectos diferentes. Assim como Carlos Reichenbach, Narahara apreciou a atuação de Kinnosuke Nakamura nesses filmes. Fã de Nakamura, Marina o associa ao Cine Niterói, da mesma forma que Yujiro Ishihara ao Cine Nikkatsu e Toshiro Mifune ao Cine Jóia. Ela gostou tanto do filme que foi assisti-lo de novo numa sessão promovida pela Fundação Japão:

Eu gostava muito de filme de samurai. Tem um ator chamado Nakamura Kinnosuke, esse era um ator mesmo, com "A maiúsculo", porque trabalhava muito bem. Nakamura Kinnosuke é da Toei, do Cine Niterói, que eu freqüentava muito. E todos os filmes em que ele aparecia, eu ia assistir, e o filme que mais me marcou é o Miyamoto Musashi, inclusive passou uma vez lá na Fundação Japão e eu fui assistir de novo, seis ou sete anos atrás.

\footnotetext{
${ }^{47}$ Ukiyo-e são pinturas coloridas feitas a partir de técnicas de xilogravura, originadas no começo do período Edo (1603-1867). O desenho é talhado e pintado em blocos de madeira. Depois esse trabalho é passado para o papel. A palavra ukiyo-e significa "personagens do mundo flutuante". Essa expressão passa a idéia de algo transitório, como se os temas retratados vagassem no tempo e no espaço (Aliança Cultural Brasil-Japão, 2009).
} 
Jo Takahashi, diretor cultural dessa instituição, além de afirmar o quanto ficou pessoalmente marcado pela plasticidade dos filmes da série, chama a atenção para o valor atribuído a ela por dois dos mais prestigiados cineastas brasileiros. Rever Miyamoto Musashi teria sido um dos últimos desejos de Rogério Sganzerla, indicando o seu afeto por estes filmes:

Eu destacaria as cinco épocas do filme Miyamoto Musashi, dirigidos pelo Tomu Uchida. Uchida para mim é o cineasta da plástica, da estética japonesa. Em termos de plasticidade acredito que ainda não apareceu um filme que substitua Musashi. [...] Foi lá no Cine Niterói que assisti os episódios de Miyamoto Musashi, que me marcaram profundamente. O Walter Hugo Khouri considerava esses filmes como os melhores da cinematografia universal. O Rogério Sganzerla, que dirigiu $O$ bandido da luz vermelha, quando ele estava internado aqui no Hospital Oswaldo Cruz à beira da morte, ele pediu para assistir ao Musashi, e um outro cineasta que estava cuidando dele, Joel Pizzini, veio aqui e pegou emprestados os nossos $d v d s$ da série para mostrar para ele, mas os médicos proibiram. Porque ele já estava muito fragilizado e um filme de ação, de samurai, com braços decepados, não seria bom. Mas era um desejo dele que eu acho que deveria ter sido atendido, ainda lembro, isso foi uma coisa recente, de três, quatro anos atrás.

Em 1962, o cineasta Masaki Kobayashi dirige para a Shochiku o filme Harakiri (Seppuku), com roteiro de Shinobu Hashimoto, o mesmo de Rashomon (Fig. 31). O filme narra a história de um samurai que, ao saber que seu filho adotivo foi forçado a estripar-se a si mesmo sob as mais cruéis circunstâncias - com uma espada de bambu, que ele portava por ter vendido sua espada real para se alimentar - planeja matar o homem que considera o responsável pela situação. Mas ao executar sua vingança, ele descobre que o responsável não é um homem, mas todo um sistema, que, tanto no passado como agora, seria parte integrante do modo de vida japonês tradicional (Richie, 1971: 137). Sedi Hirano recorda-se tanto de parte do enredo do filme, quanto da sala de cinema onde o assistiu, e ainda da reação do público diante da cena do suicídio de um de seus personagens:

Esse filme se passa na época em que a guerra começa a escassear e o samurai vende o seu espadachim. É porque a mulher dele fica grávida e ele tem que procurar emprego, mas pelo tipo de postura e vestuário via-se que ele era um samurai, e como estes não trabalhavam, não davam emprego ele. Ele tenta de tudo o que é jeito parecer com um camponês, mas não consegue. Como ele vendeu o espadachim, quando descobrem que ele andava com um espadachim de bambu, ele é condenado pelo código [de samurai] a fazer harakiri. E o samurai faz harakiri com seu espadachim, mas como ele o vendeu, teve que fazer com o espadachim de bambu. Isso passou no Cine Coral. Algumas pessoas até desmaiaram porque a cena era muito brutal.

Harakiri conquistou o Prêmio Especial do Júri do Festival de Cannes de 1963. Segundo Hirano, o filme foi exibido no Cine Coral. Ermetes Ciocheti, pesquisador do Grupo de Estudos Fílmicos, afirma que até 1963 o filme não teria sido exibido comercialmente em 
São Paulo, apenas em sessões especiais. Rodrigues (1995) caracteriza-o como um filme antisamurai, que mostraria a crueldade de seu código de honra, o bushido. A isto Novielli (2007) acrescenta que o filme faria a crítica aos eventuais resquícios do bushido na época contemporânea e a certos mitos samurais da fantasia nipônica. Para Willer, Harakiri faria parte da revisão crítica dos filmes do gênero:

A crítica que começou com Seppuku ou Harakiri, de que aquilo tudo era expressão de uma sociedade feudal, altamente hierarquizada, um sistema de relações de dominação, e também que essa mítica do samurai errante era consequiência de uma crise, quando houve a centralização.

Jean Claude Bernardet considera que Harakiri e Juramento da obediência, de Tadashi Imai, foram dois filmes tiveram influência direta sobre sua formação e sua maneira de pensar. $\mathrm{Na}$ época, Bernardet escrevia sobre cinema no jornal A Última Hora, e ele se recorda do impacto causado por Harakiri, levando-o a assistir ao filme várias vezes seguidas e escrever sobre ele por mais de uma vez. Assim como Richie e Novielli, Bernardet observa as implicações (ou comentários), deste filme de época a respeito de questões contemporâneas:

Eu lembro de Harakiri, do Kobayashi. Harakiri foi um filme profundamente marcante para mim, mas eu não lembro em que sala eu assisti. Foi um filme que eu assisti com certeza várias vezes, eventualmente várias vezes seguidas. Acredito que na época eu já escrevia na Última Hora, e eu lembro de ter escrito mais de um texto sobre o filme. Realmente eu achei um filme absolutamente extraordinário, não só pelo seu esplendor formal, pela sua geometria formal, como porque eu achava que embora se passasse no universo de samurai era um filme extraordinariamente atual, nas suas significações.

De acordo com Richie, os filmes históricos produzidos de forma corriqueira no Japão seriam marcados pela nostalgia, assumindo que as coisas seriam melhores, ou pelo menos mais interessantes, no passado. Ao mesmo tempo, no entanto, cineastas como Akira Kurosawa, Kenji Mizoguchi, Tadashi Imai e Masaki Kobayashi teriam descoberto que os problemas contemporâneos assumiriam novos contrastes dramáticos quando ambientados no passado. Deste conhecimento teria surgido um gênero cinematográfico especificamente japonês e do qual não haveria equivalente no Ocidente: o filme histórico "sério" [serious period film], no qual a história é presentificada com realismo e o presente é criticado no contexto do passado (Richie, 1971: 43). 


\title{
2.7. Crítica da tradição e subversão do status quo
}

O outro filme japonês marcante para Bernardet, Juramento da obediência (Bushidô zankoku monogatari, 1963), dirigido por Tadashi Imai, é lembrado também como um filme importante pelos cineastas Carlos Reichenbach e João Batista de Andrade. Imai e Nagisa Oshima são os cineastas japoneses preferidos de Andrade, por terem elaborado em seus filmes visões mais críticas e cruéis sobre a realidade em que viviam. Nos dois primeiros livros publicados no Brasil sobre o cinema japonês, O filme japonês (1963) e Cinema japonês (1964), José Eduardo Marques de Oliveira apresenta e avalia a obra de Tadashi Imai exclusivamente por suas posições políticas:

\begin{abstract}
Esquerdista declarado, tentando dialogar com o público, obrigando-o a participar e a meditar [...] Defendendo ações políticas esquerdistas ou criticando o liberalismo econômico, é antes de tudo um militante ativo nos problemas da época, sempre coerente com as idéias que abraçou. [...] Imai tem sido discutido e apoiado pelas correntes progressistas e atacados pelos reacionários. O importante é que sabe que todo e qualquer filme em raízes ideológicas. Nenhum é solto e gratuito. Definiu-se e luta honestamente por suas convicções. O mais não importa (Marques de Oliveira, 1963: 47-48).

Na universidade, milita na Liga da Juventude Comunista e se torna projecionista para exibir filmes de propaganda: é o seu primeiro contanto com o cinema. Ingressa no partido comunista por volta de 1955. Imai sempre defende os pobres e os oprimidos, descrevendo suas condições e suas forças. [...] Conseqüentemente acusa a sociedade feudal (e não raro acontece nos filmes de época japoneses, as acusações são válidas também para a sociedade moderna) e a sociedade capitalista (idem, 1964: 50).
\end{abstract}

A trajetória cinematográfica de Imai foi marcada pela Segunda Guerra Mundial: até agosto de 1945, como todos os cineastas japoneses, ele seria pressionado pelo governo a realizar filmes com teor nacionalista. Richie argumenta que nesse período Imai teria sido forçado a realizar os filmes Numazu heigakko (1939) e Boro no kesshitai (1943). Com o fim da guerra, o cineasta retomaria as questões abordadas nos keiko eiga ${ }^{48}$, ou seja, nos "filmes de tendência" dos anos 1920 e 1930, definindo um "novo cinema social", isto é, filmes politicamente comprometidos com as questões sociais. An enemy of the people (Minshu no teki, 1946), por exemplo, era sobre capitalistas corruptos que, durante a guerra e em conluio com os militares, realizam lucros enormes explorando os trabalhadores (Richie, 2005: 113).

Richie menciona uma análise de Max Tessier, na qual este argumenta que, se por vezes as opções de Tadashi Imai o levariam a preferir a propaganda à arte, seu humanismo

\footnotetext{
${ }^{48}$ Keiko eiga - "filmes de tendência", ou seja, subentendem um determinado argumento social, produzidos principalmente no final dos anos 1920 e início dos 1930 para dar voz ao descontentamento generalizado em clima de corrida militarista, e portanto, logo censurados (Novielli, 2007: 328).
} 
sincero sempre o protegeu das perigosas tentações do dogmatismo (Richie, 2005: 146). Himeyuri no to (1953), exibido no Cine Niterói, em novembro de 1953, com o título A torre de lis (Marques de Oliveira, 1964: 51), narra os episódios em que um grupo de enfermeiras combatentes morre durante a invasão norte-americana de Okinawa. Esse filme seria um exemplo do que os críticos japoneses chamariam de realismo nakanai (sem lágrimas) de Imai, cuja significação se daria em contraste com o rir e chorar que, como vimos, caracteriza o goshoísmo ou com namida chodai (muitas lágrimas, por favor) presente na média dos melodramas produzidos na época. Sobre os métodos do diretor, Tessier afirma que seu realismo funcionaria não apenas como um espelho da realidade, mas, mais importante, como uma pedra atirada contra esse espelho (Richie, 2005: 146-147).

Juramento da obediência foi exibido em 1963, dez anos depois de A torre de lis, no mesmo Cine Niterói. Nesse mesmo ano, o filme conquistou o Urso de Ouro (Prêmio de Melhor Filme) no Festival de Cinema de Berlim. Apesar do prêmio internacional, esse filme não é comentando por historiadores do cinema japonês, como Richie $(1971,2005)$ e Novielli (2001). Para José Fioroni Rodrigues, trata-se de um filme anti-samurai:

Tadashi Imai agora nos dava Juramento da obediência, um poderoso filme anti-samurai desfilando incríveis degradações que os membros de uma família sofrem dos senhores feudais através das gerações até os dias atuais, em que um funcionário de grande companhia mais uma vez tinha que se submeter à vontade do chefe [...] (Rodrigues, 1995: 169).

Jean Claude Bernardet e João Batista de Andrade re-elaboram lembranças intensas sobre esse filme, que guardam semelhanças entre si. Há a percepção comum das relações de vassalagem, ou de subserviência, que se reproduzem em diferentes circunstâncias históricas:

Juramento da obediência é uma série de episódios que se passam em momentos diversos da história do Japão, desde o que nós chamamos aqui de Idade Média até depois da guerra, até o advento do capitalismo, então são sete episódios. Cada episódio apresenta uma relação entre senhor e vassalo. Às vezes propriamente, dentro da estrutura da história japonesa, às vezes impropriamente, se é o dono de uma empresa no capitalismo moderno e o operário. $\mathrm{E}$ o que temos? Temos uma grande variedade de épocas históricas, portanto de figurino, da maneira de interpretar, de atores, uma grande variedade. Porém, dentro desta variedade, há um denominador comum. No início do filme você não sabe, eu pelo menos não sabia que era um filme de vários episódios. Aí acaba e vem o segundo. Você vê o segundo episódio. Quando chega no terceiro episódio você pensa: esta relação eu já vi. Então eu fui profundamente marcado por este filme (Jean Claude Bernardet).

Eu vi um filme do Tadashi Imai que eu fiquei muito ligado, o Juramento da obediência. É um filme profundamente brechtniano. E me marcou porque o foco dele era a subserviência do japonês, do trabalhador japonês. E a subserviência mostrada reiteradamente, quer dizer, é um massacre ideológico sobre o espectador, sem ser uma lavagem cerebral ou a imposição de uma idéia. É um massacre no sentido de: olha como você é subserviente. Pegava uma história de 2000 anos atrás, com a qual o japonês se identificaria, entre o suserano e o 
samurai. É o mesmo personagem atual que trabalha numa grande empresa multinacional, e a noiva dele trabalha na empresa concorrente. Eles vão se casar, mas o chefe dele fica contra e fala que não. E ele entra no maior parafuso porque ele vai acatar. Aí o Tadashi Imai pega e volta o cara lá 2000 anos atrás, como um samurai. E o Juramento da obediência é ele obedecendo ao suserano em situações deste tipo. Volta ao presente de novo e ele na batalha, a noiva discutindo com ele, e volta a 1500 anos atrás, numa outra situação e vai, ele como operário depois lá na subserviência ao chefe, ao suserano, ao imperador, até o presente: ele com um problema, com um dilema e o que fazer? Então é um filme impressionante, muito forte (João Batista de Andrade).

Com relação aos filmes de esquerda, como classifica Juramento da obediência, Carlos Reichenbach nota uma diferença entre o gosto do público nissei, isto é, dos filhos dos imigrantes japoneses nascidos no Brasil, que poderiam eventualmente assistir e compreender esse tipo de filme, e o gosto do público formado pela geração dos imigrantes, que estaria mais ligado aos filmes comerciais e de época. As relações sexuais homossexuais seriam uma das formas de subserviência descritas pelo filme, antecipando em mais de trinta anos o olhar de Nagisa Oshima sobre tema em Tabu (Gohatto, 1999). À abordagem desse assunto, Reichenbach parece relacionar um certo desconforto do público japonês:

Dava para perceber nitidamente que havia uma diferença entre o público nissei com o público japonês mesmo, que realmente tinha mais vínculo com o cinema tradicional, que preferiam ver os filmes de época e os mais comerciais do que os filmes de esquerda, os filmes do Tadashi Imai, entendeu? Juramento da obediência, que é uma história de samurai com bicha, aliás, magnífico filme. Juramento da obediência é fantástico. É a história da relação entre mestres samurais e seus discípulos. Um dos poucos filmes que tocam no assunto, muito antes que o filme do Nagisa Oshima, mas muito antes, foi corajoso.

Pedra atirada contra o espelho, massacre ideológico sobre o espectador, filme que põe o dedo na ferida. Se na fala de Reichenbach o incômodo dos espectadores da primeira geração (iseis) com Juramento da obediência é apenas pressentido, Andrade recorda-se nitidamente da reação despertada pelo filme junto a esse público:

Tinha gente que se levantava da sala no meio da projeção, porque aquilo pegava lá no âmago da pessoa [gestualiza para dentro da cabeça], era perturbador, entendeu? E era um filme que tinha como centro o fascismo japonês e essa obediência ao imperador, à autoridade e aos grandes empresários, que era uma marca da vida japonesa, então aquilo era doloroso para as pessoas. [...] Eu lembro de gente sair bufando, sair reclamando do cinema, a partir do meio do filme o pessoal não agüentava ver aquilo. É um cinema muito brechtniano, muito duro. Mas é um enfrentamento também por parte dos cineastas de uma questão importante na vida japonesa, na formação cultural japonesa. Então o cara põe o dedo na ferida mesmo.

Richie observa que, a despeito dos conteúdos anti-tradicionais presentes nos filmes de Imai, estes seriam quase destituídos de estilo, isto é, de uma apresentação visual-aural 
consistente. A individualidade de Imai repousaria mais em seu testemunho e nos assuntos tratados pelos filmes do que num estilo forte e individual. Apesar do ecletismo de seu método, o teor de seus filmes apresentaria uma notável coerência (Richie, 2005: 149). Bernardet, no entanto, valoriza justamente a articulação entre a forma e o conteúdo do filme Juramento da obediência, que criaria as bases para um cinema ensaístico, apoiado não em conceitos verbais, mas em estruturas narrativas e na montagem:

Para mim isto é uma das estruturas do cinema ensaístico. Quer dizer, é uma das estruturas possíveis, não é a única, nem é necessária. Mas falando de filmes que poderiam ter uma vocação ensaística e que não queiram usar o conceito verbal [e que tornaria a imagem meramente ilustrativa do conceito], é através das estruturas narrativas e de montagem que esse conceito pode emergir, justamente por ser o denominador comum dentro de uma variedade. Até hoje eu estou marcado por isto, até hoje isto é uma questão absolutamente central da minha reflexão sobre a possibilidade do cinema ser ensaístico e de produzir um discurso filosófico. Isto não é uma regra, muitos filmes que produzem discursos filosóficos não se valem disto, mas é uma das possibilidades.

Além de ensaísta e professor de cinema, Jean Claude Bernardet teve alguns de seus textos adaptados e participou da elaboração de roteiros de importantes filmes brasileiros, como O caso dos irmãos Naves (Luís Sérgio Person, 1967), Gamal, delírio do sexo (João Batista de Andrade, 1968), Orgia, ou o homem que deu cria (João Silvério Trevisan, 1970), e mais recentemente, Um céu de estrelas (1996) e Através da janela (2001), ambos de Tata Amaral.

Nos anos 1960, em parceria com Person, Bernardet escreveu ainda dois roteiros não filmados: SS contra a Jovem Guarda, cuja elaboração contou com a participação do comediante Jô Soares e do dramaturgo Lauro César Muniz, e A hora dos ruminantes. Se o primeiro era um projeto com o cantor Roberto Carlos, cujo sucesso poderia ajudar na produção de $O$ caso dos irmãos Naves, o roteiro de $A$ hora dos ruminantes apresentaria uma afinidade temática com o filme sobre os Naves - ambos abordariam a violência e sua aceitação, a passividade da classe média e um certo tipo de revolta (Bernardet, [1967] 1997: 283), ou seja, através de alegorias, referia-se também ao golpe militar de 1964. O que nos interessa aqui é que a construção desse roteiro foi inspirada pela estrutura ensaística observada por Bernardet em Juramento da obediência:

Juramento da obediência, eu não lembro em que sala eu assisti, mas foi um filme profundamente marcante no momento eu estava trabalhando com o [Luís Sérgio] Person. Person e eu fizemos, juntos, um único filme, $O$ caso dos irmãos Naves (1967), mas trabalhamos em vários projetos, um deles foi $A$ hora dos ruminantes. E a estrutura desse filme provém do Tadashi Imai. Person não conhecia esse filme, mas eu tinha falado muito para ele do que é que tinha me impressionado, quando eu comecei a estruturar $A$ hora dos ruminantes. Depois de escrito o roteiro, foi feita uma leitura para o Lauro César Muniz na casa do Person. E o Muniz divergiu totalmente da estrutura, que considerou um grande erro. 
[...] O que ele criticou no roteiro que eu escrevi com o Person é justamente esta repetição: nós colocamos os episódios seguidos. E o roteiro é uma alegoria bastante diferente do livro original, inclusive o J. J. Veiga tinha gostado muito da adaptação. É uma alegoria em que "homens", que evidentemente representam os militares, pressionam e oprimem pessoas de um lugarejo. Person e eu trabalhamos assim: é quatro vezes a mesma coisa, só que é quatro vezes pior. Inicialmente o que os homens pedem é pouca coisa e a pressão é pequena, e é maior e maior até que no fim é plenamente a ditadura, a cidade é invadida, etc. O Lauro nos aconselhava a fazer a montagem paralela das histórias. Quando o Lauro saiu do apartamento do Person, eu disse o seguinte: - O Lauro entendeu perfeitamente o que nós fizemos, só que ele não aceita. Agora, a minha posição era de manter isto. E o Person esteve de acordo e nós mantivemos. Depois o produtor Civelli adoeceu e a produção foi interrompida.

Outro filme comentando por diversos freqüentadores dos cinemas da Liberdade é a trilogia Guerra e humanidade (Ningen no joken, 1959-1961), dirigida por Masaki Kobayashi (Fig. 32) ${ }^{49}$. Trata-se de uma adaptação do romance de Unpei Gomikawa em 10 horas de narrativa fílmica divididas em três partes, tendo a primeira delas conquistado o Prêmio San Giorgio do Festival de Veneza. Futemma comenta sobre as filas formadas para assistir ao filme no Cine República: "Em 1962, a praça da República conhece filas de japoneses e brasileiros esperando a vez de assistir à primeira parte de Guerra e humanidade, de Masaki Kobayashi, no Cine República” (Futemma, 1986: 79). Reichenbach, no entanto, lembra de ter assistido ao filme no Cine Coral. Em sua fala reaparece a relação entre o Cine Scala com os filmes da Toho, citada anteriormente por Sternheim:

Guerra e humanidade foi lançado no Cine Coral, que era o cinema que exibia os filmes franceses, que era inclusive da Franco-Brasileira. O Cine Coral passou bastantes filmes japoneses. Numa época havia estas duas salas, o Cine Coral e o Cine Scala, que ficava na rua Aurora, naquele trecho entre a [avenida] São João e o Largo do Arouche, onde passou bastante filme japonês. Acho que Na trilha das feras, os filmes do Sugawa passavam lá e outros filmes importantes, normalmente os filmes da Toho, que eles lançavam também, não era um cinema dedicado exclusivamente ao cinema japonês.

Guerra e humanidade é descrito como épico por Jo Takahashi e João Batista de Andrade. Richie afirma que esse filme seria o primeiro do pós-guerra a mostrar o exército japonês como ele realmente teria sido, tornando-se uma das produções mais controversas já realizadas no Japão. Nesse filme, a crítica ao exército se estenderia ao sistema de organização japonês por inteiro (Richie, 1971: 136). Audie Bock (1980) faz uma descrição semelhante de um filme anterior de Kobayashi, The thick-walled room (Kabe atsuki heya, 1953), que teria sido censurado pela própria Shochiku por pressão do governo de ocupação norte-americano: baseado em diários de prisioneiros de "baixa patente" acusados de crimes de guerra, o filme

49 Guerra e humanidade é citado nos depoimentos de Jo Takahashi, João Batista de Andrade e Alfredo Sternheim. O filme é comentado nos depoimentos de Olga Futemma, Sedi Hirano, Carlos Reichenbach e Carlos Willer. Os textos de Futemma (1986) e Rodrigues (1995) fazem também referência a este filme. 
indicaria de forma clara, através de flashbacks, que eles estariam apenas cumprindo ordens sobre as quais não teriam escolha, na cruel inumanidade do sistema do exército imperial japonês. Uma maior simpatia pelos personagens, descritos como bodes expiatórios, seria assegurada com a descrição dos efeitos dos anos de encarceramento em seus entes queridos uma garota pura do interior torna-se prostituta, satisfazendo soldados norte-americanos.

Neste filme, Kobayashi e o roteirista Kobo Abe instituíram o que depois viria a se tornar uma prática comum dos cineastas da nouvelle vague japonesa, ao formar sua própria companhia de produção (Shinei Productions) e cobrar da Shochiku que cumprisse a promessa de distribuição, o que ela faria apenas três anos depois (Bock, 1980: 250). De forma semelhante, os direitos do livro de Gomikawa foram adquiridos por Kobayashi para a companhia de produção independente Ninjin, co-produtora de Guerra e humanidade junto com a Shochiku, que teria inicialmente relutado na realização do projeto (idem, ibidem: 251). Em abril de 1967, ao comentar sobre a crise do sistema de estúdio japonês e a alternativa do cinema independente distribuído pelas cadeias de cinema das grandes companhias, Jairo Ferreira menciona outro filme de Kobayashi, As quatro faces do medo (Kaidan, 1964):

Em recente entrevista para uma revista européia, o ator Toshiro Mifune declara que o cinema japonês está à beira do suicídio. E acrescenta que a solução está nas empresas independentes. Assim, um dos grandes filmes aqui exibidos no ano passado, As quatro faces do medo, de Kobayashi, era uma produção independente distribuída pela Toho (Ferreira, [1967] 2000, 124).

Segundo Bock, dos maiores cineastas japoneses surgidos no período do pós-guerra, Kobayashi é o que carregaria as cicatrizes mais profundas da Guerra no Pacífico. A experiência pessoal e os problemas filosóficos "do maior trauma japonês do século XX" se tornariam matéria bruta de sua arte. Em maio de 1941 ele ingressou nos estúdios da Shochiku de Ofuna, onde trabalhou por apenas oito meses até ser convocado pelo exército em janeiro de 1942. Sua oposição à crueldade do sistema do exército imperial japonês conseguiria apenas se expressar na recusa em lidar com os recrutas de maneira hierárquica. Essa resistência passiva remeteria, de imediato, às ações do herói pacifista do épico Guerra e humanidade, sobre quem ele teria dito: "Eu sou Kaji no filme". Em 1944 ele seria transferido para a ilha de Ryukyu, onde assistiu ao fim da guerra. Mas Kobayashi ficaria preso ainda num campo de detenção em Okinawa por um período de um ano, retornando ao estúdio da Shochiku apenas em novembro de 1946, onde ele recomeçaria do zero (Bock, 1980: 248). 
A descrição que Novielli faz do enredo da trilogia de Kobayashi remete aos episódios da experiência pessoal do cineasta, além de apontar para uma possível mudança em sua avaliação a respeito das responsabilidades pela guerra em relação ao filme de 1953:

No âmbito dos filmes de tese, os do diretor Masaki Kobayashi, muitos dos quais se opõe fortemente à guerra, adquirem matizes particulares. A diferença consiste no tipo de abordagem das problemáticas, que no caso deste diretor nunca se revelam politicamente definidas, mas se propõe a criar um forte desconforto em qualquer pessoa que assista aos filmes, apontando que todos são de alguma forma culpados pela situação. [...] Na primeira parte, conta-se a história do engenheiro Kaji, que é enviado com a mulher à Manchúria, onde trabalha no escritório de uma mineração. Transtornado pelas condições desumanas as quais são obrigados os chineses, tenta melhorar a situação, mas acaba por ser torturado e enviado à frente de batalha no norte do país. No segundo filme, Kaji deve confrontar-se com a brutalidade da guerra e do comportamento dos superiores com relação às tropas. Na última parte, Kaji e seus homens são aprisionados pelas divisões soviéticas. Em fuga e esperando rever sua mulher, ele morre numa planície coberta de neve. $O$ filme apresenta alguns excessos sentimentais, mas também seqüências inesquecíveis, expressões de uma experiência vivida em primeira pessoa por Kobayashi durante a permanência e a prisão na Manchúria. No desenvolvimento da personalidade de Kaji, o herói puro vai se transformando de vítima (porque partícipe da tragédia das vítimas, seja os chineses nas minas, seja os soldados japoneses) em um dos tantos carrascos: é consciente de agir mal, mas sua escolha se deve à necessidade de sobreviver naquelas condições desesperadoras. No fundo não é mais do que um homem - sugere Kobayashi (Novielli, 2007: 154-155).

Guerra e humanidade foi um dos primeiros filmes japoneses assistidos pelo sociólogo

Sedi Hirano, no início dos anos 1960, época em que ele estudava no curso científico do Colégio Roosevelt e participava da militância estudantil. Da trilogia de Kobayashi, Hirano lembra-se de duas seqüências marcantes, na primeira delas referindo-se à mensagem socialista do filme e na segunda, ao seu caráter humanista:

Guerra e humanidade tem uma mensagem socialista. Eu me lembro de que ele participava de varias frentes de guerra, e tinha uma mulher e filha. Numa das cenas mais tocantes dois personagens conversam, aí um deles olha para o outro e fala: - Aqui é o futuro, e esse é o futuro que nós almejamos e sonhamos. Aí o outro diz: - Sempre o jardim do outro é mais bonito do que o nosso, mas o que nós precisamos é transformar o nosso num jardim tão bonito quanto o do outro. Então é uma pessoa vendo o socialismo do outro lado, e não socialismo do seu lado. Aí o outro diz: - Não, nós precisamos construir esse outro lado, se possível de uma forma mais bela e mais brilhante. Você percebe que tem uma mensagem, porque Guerra e humanidade é um filme de um diretor de esquerda. Tem uma outra cena tocante em que ele morre, ele está retornando para o lar, mas ele guarda um onigiri [bolinho de arroz], porque é o onigiri é muito simbólico. Ele guarda e não come, mesmo passando fome, porque ele quer levar para a mulher. E ele morre sem comê-lo, levando-o para a mulher. É a questão de querer bem o outro, do amor ao companheiro, é um filme muito bonito. Eu assisti, aliás, influenciado pelo Irineu, esse cara que era comunista.

Nessa mesma época, Carlos Reichenbach era estudante do curso clássico do Colégio Rio Branco. Em contraste com as lembranças de Hirano sobre o enredo de Guerra e 
humanidade, Reichenbach relembra que a primeira crítica de cinema que ele escreveu foi justamente sobre esse filme, a pedido de um professor de português que teria sido um dos primeiros a estimulá-lo a seguir carreira na área de cinema:

Para mim foi um grande tema, porque foi a primeira crítica de cinema que eu escrevi na vida foi numa matéria do Colégio Rio Branco. Eu tive um professor de português que foi talvez a pessoa que mais me estimulou a seguir a carreira, a estudar cinema. Ele falou: escrevam sobre o que quiserem, sobre um filme. E eu escrevi sobre Guerra e humanidade. Ele ficou impressionado com o fato de que um garoto ficasse tão interessado naquele filme pelo qual ele era fascinado também. E ele ficava me estimulando a escrever mais. Eu me lembro deste impacto grande, não que seja único, eu me lembro de ter visto Guerra e humanidade quando eu já freqüentava os cinemas da Liberdade.

$\mathrm{Na}$ vertente dos cineastas contestadores ou rebeldes, Eizo Sugawa é um realizador cujos filmes foram apreciados e analisados pela crítica de cinema paulista na época e ainda hoje são lembrados por diversos antigos freqüentadores das salas da Liberdade ${ }^{50}$. Um primeiro aspecto que chama à atenção na trajetória dos filmes desse cineasta é o apreço conquistado pelos mesmos junto à parte da crítica e do público brasileiros, em contraste com a quase ausência de reconhecimento de sua obra pela crítica de cinema japonesa. Ele é qualificado como niilista por Marques de Oliveira e como contestador e anarquista por Rodrigues:

A consagração do niilista Eizo Sugawa, por parte de alguns setores da crítica brasileira, surpreendeu aos japoneses (Marques de Oliveira, 1964: 74).

O então novato Eizo Sugawa com três filmes seguidos: Morte à fera, Arma fatídica e Desafio à vida - empolgou os fãs daquela época. Contestador e anarquista, Sugawa nunca recebeu o apreço que merecia em sua terra natal (Rodrigues, 1995: 166).

Em texto publicado no jornal Folha de S. Paulo, em setembro de 1995, Inácio Araújo comenta: "Sugawa, 65, diretor de filmes como Morte à fera, Na trilha das feras, Uma mulher de Osaka (da primeira metade dos anos 60), certamente é mais apreciado no Brasil do que no Japão, onde monstros sagrados da crítica torcem o nariz ao ouvir falar dele" (Araújo, 1995). De maneira sintomática, isto é, acompanhando a crítica de cinema japonesa, nenhum filme de Sugawa é citado ou comentado nos livros sobre a história do cinema japonês de Richie (1971, 2005) e Novielli ([2001] 2007).

Carlos Reichenbach fala sobre o interesse despertado pelos filmes desse realizador, que define como niilista e anarquista: "No caso específico do Sugawa, é o viés niilista que me

50 Os filmes de Sugawa foram citados por Sedi Hirano e comentados por Alfredo Sternheim, Carlos Reichenbach, Cláudio Willer, João Batista de Andrade e Jean Claude Bernardet. Os críticos de cinema Rubem Biáfora, Jairo Ferreira, José Fioroni Rodrigues e Orlando Parolini escreveram sobre o filme. 
interessa muito, acho que em vários momentos ele deixa nítida uma visão libertária do mundo, mais anárquica". Em relação ao filme Morte à fera (Yajû shisubeshi, 1959), Reichenbach comenta: "Eu vi na Liberdade e eu vi fora. Uma vez esse filme foi reprisado por indicação minha. E a mostra do Sugawa, que de uma certa forma fui eu que briguei para trazêla ao Brasil, quando eu estive no Japão".

A viagem a que Reichenbach se refere foi promovida pela Fundação Japão em 1995, tratando-se da mesma que deu ensejo ao texto de Inácio Araújo e também ao episódio, citado anteriormente, no qual Bernardet e Ismail Xavier assistiram a uma apresentação de teatro kabuki. A delegação brasileira encontrou-se com Eizo Sugawa em Tóquio. Em 1996 foi realizada uma extensa retrospectiva dos filmes do cineasta na $20^{\mathrm{a}}$ Mostra Internacional de Cinema de São Paulo, dois anos antes de seu falecimento, em 1998. Sobre o encontro com Sugawa no Japão, Araújo escreve:

Até a direção do Festival de Cinema de Tóquio se mobilizou para colocá-lo em contato com os brasileiros que vieram ao Japão. [...] Sugawa foi convidado para as palestras feitas na última quinta, na Fundação Japão, por Walter Hugo Khouri e Ismail Xavier. Ouviu de boca aberta José Fioroni Rodrigues recitar o título original de seus filmes e comentá-los [...] É bem possível que se possa ver, em 1996, uma retrospectiva de seus filmes no Brasil. Já começou a ser armada. E Sugawa, ao ouvir a proposta, outra vez sorriu de orelha a orelha (Araújo, 1995).

Jairo Ferreira observa que, numa época em que predominavam as aventuras de samurai e os melodramas exacerbados, Morte à fera seria um filme de exceção no cinema japonês (Ferreira, 1986). Cláudio Willer afirma que o filme foi exibido no Cine Coral. Como visto, Carlos Reichenbach recorda-se que a seqüência desse filme, Na trilha das feras (1964), foi exibida no Cine Scala. Há ainda uma fotografia da fachada do segundo Cine Niterói, localizado na avenida Liberdade, em que o mesmo filme é anunciado (Fig. 33). Segundo Ferreira, esses dois filmes, junto com Caça às feras (1973), fazem parte de uma mesma trilogia sobre os efeitos da industrialização vertiginosa no Japão do pós-guerra. O olhar retrospectivo do crítico percebe que, frente às mudanças ocorridas no país de 1959, ano do primeiro filme, a 1973, Sugawa teria recuado em sua tese de que o crime compensa:

Caça às feras é o último exemplar de uma trilogia eclética que Eizo Sugawa inaugurou com o eletrizante Morte à fera e desenvolveu com o também inquietante Na trilha das feras, thrillers niilistas que dissecavam implacavelmente as mazelas da primeira arrancada industrial no Japão ainda convalescente dos traumas pós-Segunda Guerra Mundial. Em Morte à fera, Sugawa apresenta o seu deflagrador personagem principal, Date Kun [brilhante interpretação de Tatsuya Nakadai], como um novo tipo de assassino que surgiria nos grandes centros urbanos. [...] Kun age impulsivamente. Sua trajetória de crimes começa com a explosão de uma bomba de fabricação caseira no campus da universidade. $\mathrm{O}$ 
personagem é um inconformista, um revoltado, um terrorista. O que faz é contestar radicalmente um sistema no qual não vê perspectivas. E a abordagem existencial de Sugawa deixa evidente a sua empatia com esse anti-herói ao mesmo tempo em que a ação da polícia é minimizada. [...] O Japão tinha mudado muito entre 1959 e 1973. Sugawa não sustentou até o fim a sua tese ou axioma de que o crime compensa. Se Caça às feras tivesse sido realizado nos anos 60, a polícia certamente seria ludibriada pelos seqüestradores. Restou então a impressão de que o filme é uma retratação do cineasta diante da polícia de seu país. Irônico epílogo para um cineasta iconoclasta que ousou demolir as instituições japonesas enquanto isso foi possível (Ferreira, 1986) ${ }^{51}$.

Vinte anos antes, em artigo publicado em agosto de 1967 no jornal São Paulo Shimbun, Jairo Ferreira descreveu a identidade existente entre o "herói" do bang-bang [western] e o da aventura policial, gêneros cinematográficos cujas coordenadas limitariam os personagens entre o bem e o mal. A única exceção seriam os filmes de Sugawa: “Apenas Eizo Sugawa, em Morte à fera teve peito para afirmar que o 'bandido' era um herói” (Ferreira, [1967b] 2006: 45). Cláudio Willer e Jean Claude Bernardet, no entanto, associam o tipo de personagem do filme japonês aos de outros filmes realizados na época, como Acossado (À bout de souffle, 1960) de Jean-Luc Godard, Canal (Kanal, 1957) e Cinzas e diamantes (Popiól i diament, 1958), ambos do cineasta polonês Andrzej Wajda:

É a história de um bandido, sob a ótica do bandido. Mas isso também começou a ter no cinema europeu. Note bem que é precedido pelo Acossado, do Jean-Luc Godard, que já tinha dado esta virada, já que o Jean Paul Belmondo é um bandido. Então estava dentro de um ambiente de época, quer dizer, também acaba morto no final, mas o tempo todo ele é humanizado, tratado como um personagem interessante, nesta absoluta obra-prima do Godard (Cláudio Willer).

Morte à fera era bastante diferente, era, pelo que eu estou lembrado, mais o fascínio do cinema urbano, violento, histérico. Era um ator jovem, que eu não me lembro quem era este ator, que eram esses adolescentes perturbados, que na França poderia se chamar Jean Paul Belmondo, que o Wajda tinha também em Cinzas e diamantes, Canal, esses adolescentes um pouco enlouquecidos no meio de um turbilhão urbano. Morte à fera era muito violento (Jean Claude Bernardet).

Alfredo Sternheim e Carlos Reichenbach recordam-se de problemas enfrentados pelo filme na época de seu lançamento, tanto com a censura brasileira quanto com, eventualmente, a própria Toho. Sternheim fala o prêmio Saci (Melhor Filme Estrangeiro) concedido pelos críticos de cinema paulistas ao segundo filme da trilogia de Sugawa e da mobilização em torno da liberação do primeiro junto aos órgãos da censura brasileira. Reichenbach fala de um

\footnotetext{
${ }^{51}$ Esta interpretação de Jairo Ferreira é semelhante com o que escreve Inácio Araújo sobre Eizo Sugawa em 1995: "Hoje, lembra seu desesperado radicalismo como algo 'de juventude'. É um diretor reconciliado com o Japão e, aparentemente, com a vida" (Araújo, 1995).
} 
falseamento do final de Morte à fera por meio de um letreiro explicativo, inserido nas cópias destinadas à distribuição estrangeira ou, pelo menos, na cópia enviada ao Brasil:

Sugawa foi um diretor que a gente descobriu aqui no Brasil eu e o Biáfora, e ele ganhou o prêmio Saci, que era um prêmio que a gente dava todo ano aos melhores do cinema brasileiro, e dava um Saci ao melhor diretor de filme estrangeiro. E o Sugawa ganhou, naquela época [1965], com Na trilha das feras. Morte à fera teve complicações, a gente fez até abaixo assinado porque a censura brasileira não queria que o filme passasse no Brasil, diziam que o filme fazia uma apologia do crime e tudo mais (Alfredo Sternheim).

Em Morte à fera há um letreiro no final que foi colocado para distribuição estrangeira. Porque no filme o cara quer ir para os Estados Unidos, mata todo mundo lá [no Japão] para poder estudar no estrangeiro, mas acho que no Brasil colocaram um letreiro no final: "Ele foi preso assim que chegou no aeroporto". Isto é uma mentira, isto não tinha no filme. O filme foi acusado de niilista, reacionário, etc., o que é uma besteira, porque é um filme exatamente sobre a vitória do cinismo, é contestatório, e não reacionário (Carlos Reichenbach).

Morte à fera foi objeto de um intenso debate na época de seu lançamento em São Paulo, sendo acusado de nazi-fascista pela "esquerda nacional”, neste caso, de viés socialista, e, ao mesmo tempo, elogiado como contestador, libertário ou como intérprete da juventude mundial por aqueles identificados com idéias anarquistas. Ressonâncias desse debate são ainda percebidas no depoimento de João Batista de Andrade sobre o filme de Sugawa, de quem diz não gostar, e na descrição do poeta Orlando Parolini sobre os contextos de produção (Japão) e de recepção (Brasil) do filme, apresentados como indissociáveis por conta das tensões causadas pela Guerra Fria em ambos os países:

Eu não gosto do Eizo Sugawa. Não gosto de Morte à fera. Eu acho que é um cinema que eu identificava como quase pró-fascista, muito niilista e que o ser humano em última instância é essencialmente mal, ruim, entendeu? Você ajudar alguém, levar para casa era como levar uma cobra para casa: uma hora ela vai te morder. Era um pouco essa visão do ser humano com a qual eu não concordo. Mas era um bom cinema, não era ruim não. Mas estava muito longe da qualidade de um Ozu, de um Oshima, de um Mizoguchi. Embora ele fizesse um cinema mais moderno, puxado mais para a modernidade e para a atualidade, eu não gostava, tinha muita resistência a ele (João Batista de Andrade) ${ }^{52}$.

Dos diretores japoneses com menos de 30 anos cujos filmes foram lançados no Brasil, a figura de Sugawa Eizo se ressalta. Criticado pela esquerda nacional, que viu nele o modelo de novo nazista, taxado de louco e paranóico pela análise psicológica do protagonista de Morte à fera, Sugawa permanece acima dessas classificações ridículas como intérprete fiel de uma grande parte da juventude de todo o mundo. Não uma juventude bitolada de

\footnotetext{
52 Jean Claude Bernardet faz um paralelo entre esta polêmica e a que envolveu o aparecimento do Cinema Marginal: "Esta discussão, ela teve também lugar no Brasil quando apareceu o cinema marginal. E que este ceticismo, esta perda das utopias, tudo isto, e algumas pessoas, alguns críticos, cineastas etc. achavam que este cinema era um cinema negativo, mas eu nunca pensei isto. Inclusive o Hitler $3^{\circ}$ Mundo eu acho um filme maravilhoso, tinha um samurai, você conhece este filme?"
} 
esquerda, direita ou centro, mas de uma juventude para a qual nenhum regime socialpolítico poderá oferecer qualquer caminho a trilhar e tirá-la do caos em que a geração passada a lançou. Chamam-no de niilista. Seu niilismo, no entanto, parte de um ponto em que para ele as doutrinas sociais ou religiosas já contribuíram com tudo o que poderia contribuir e, se da aplicação delas poderão surgir efeitos benéficos, estes virão demasiadamente lentos. Nós não podemos esperá-los. É necessário viver intensamente até as últimas consequiências. Viver hoje significa usufruir todos os prazeres do corpo e do espírito, mesmo que para isso tenhamos que mandar a moral e as convenções às urtigas. Se não temos coragem, daí a nossa tragédia, a culpa será nossa, pois, de ambos os lados, milhares de bombas aguardam um momento oportuno. É sob essa tensão nervosa que agem os personagens de Sugawa. E a carga de nervosismo é tamanha que um gesto, um olhar do próximo serão capazes de transformar o homem num assassino ou levá-lo à própria destruição (Parolini, 1963: 96).

$\mathrm{Na}$ revisão dos filmes de Sugawa proporcionada pela retrospectiva da Mostra Internacional de Cinema de São Paulo, Volúpia da vingança (Yajû shisubeshi: fukushû no mekanikku, 1974) é o filme que mais impressionou Reichenbach, que o define como moderno e espantoso devido à sua limpeza, ao contrário de Morte à fera, que seria um filme de jovem, contestatório. Da mesma forma como Ferreira qualificou esse filme, Reichenbach classifica Volúpia da vingança como um filme de exceção:

Perguntaram a mim sobre os filmes que eu gostaria de ter feito. Um dos filmes que eu gostaria de ter feito é Volúpia da vingança do Sugawa. É a história de um professor niilista e do aluno que fica tentando seguir os passos dele. Tem uma coisa da vingança da organização que provocou a humilhação do pai. $O$ filme foi desenvolvido de forma operística, dizem que era filmagem disfarçada de Morte à fera, mas acho que era muito mais do que isto. Eu acho que é um processo de maturidade do Sugawa, é um filme de mais maturidade que Morte à fera. Tão amargo e niilista quanto o outro. Mas ele tem um peso trágico, uma beleza seca que absolutamente me fascina. Eu acho que é um filme raro. Você não encontra filmes parecidos com este, é um filme de exceção. É um filme absolutamente original, é magistral! E ao mesmo tempo, estilisticamente é um filme limpo, não tem firula, é um filme muito estranho. Eu gostaria de ter feito este filme.

Indagado sobre seus atores preferidos, Cláudio Willer cita Takakura Ken, dos filmes de samurai, mas lembra-se com dificuldade dos nomes dos atores mais velhos, como Kinnosuke Nakamura, o intérprete de Musashi na versão de Tomu Uchida. Ao ser citado o nome de Tatsuya Nakadai, no entanto, ele passa a falar com entusiasmo sobre a atuação do ator em filmes que o impressionaram na época:

Ah, mas aí a coisa muda de figura! Mas aí já não é mais o cinema típico de samurai. De Tatsuya Nakadai, o primeiro filme que vimos dele foi Morte à fera, de Sugawa, cineasta colossal. Aí o ator impressionou. Nakadai é o melhor, tanto é que o Kurosawa foi buscar ele para o Ran e para o Kagemusha, é um ator com recursos expressivos prodigiosos. Na época ele impressionou em Morte à fera e em Harakiri. 
Nakadai foi descoberto pelo cineasta Masaki Kobayashi, que lhe confiou o papel principal de Guerra e humanidade. Para Audie Bock, o personagem pacificista Kaji teria sido interpretado com perfeição por Nakadai (Bock, 1980: 251). Em O filme japonês, Ermetes Ciocheti comenta: "A interpretação de Tatsuya Nakadai, pela extrema complexidade do personagem Kagi e pela extensão da obra, foi a melhor de quantas já vi” (Ciochieti, 1963:60). Reichenbach afirma que Nakadai estaria em todos os filmes importantes daquela década, incluindo, além dos filmes já citados, a atuação do ator em Fera azul (Aoi yaju, 1960), dirigido por Hiromichi Horikawa.

O crítico de cinema Rubem Biáfora nunca apreciou o trabalho de Tatsuya Nakadai como ator, desde o seu aparecimento, no início dos anos 1960. Isto é ainda perceptível num texto publicado em $O$ Estado de S. Paulo relacionado ao lançamento do filme, Kagemusha, a sombra do samurai (Kagemusha, 1980), de Akira Kurosawa, em São Paulo:

Pena que para este duplo personagem [o chefe guerreiro e o sósia], Kurosawa tenha brigado com a sua primeira opção, Shitaro Katsu, e para substituí-lo tenha convocado o extremamente poseur e artificioso Tatsuya Nakadai. Apesar disso, entretanto, um filme de muito empenho e ambição que precisa ser visto (Biáfora, [1981a] 2006: 129).

Reichenbach comenta sobre a implicância de Biáfora com determinados atores, especialmente Nakadai, e sobre a relação de seu grupo de amigos com o crítico de cinema, de quem eram fãs, mas adoravam discordar. Ele relembra de um episódio envolvendo Biáfora e este ator:

A gente dizia que o Biáfora era aquele tipo de crítico que nós adorávamos discordar. Eu gostava muito do Biáfora, mas ele tinha paixões, ele odiava o Tatsuya Nakadai, a gente não perdoava isso. Eu não sei porque. Ele tinha um texto que falava que Tatsuya Nakadai é uma enganação. Eu falava: - Você está louco! Um dos maiores atores da face da terra! Mas ele tinha essa coisa meio passional com atores, ele tinha fascinação por atores de sangue germânico, umas coisas absurdas assim. Era coisa dele, estranhice dele. Não gostava daquele cara, o Kinnosuke [Nakamura], que era genial, do Miyamoto Musashi. Mas tinha umas cismas, com o cinema japonês então, tinha várias. Gostava de Tetsuru Tamba, não gostava de Toshiro Mifune, mas a implicância era com o Tatsuya Nakadai. Mas que puta implicância! Mas era bom porque de certa forma era estimulante. [De todo modo vocês eram de gerações diferentes, o que ele gostava devia ser diferente do que você, Jairo...] Ah, totalmente. Era o contrário [risos]. Era uma molecagem. Puta! Chegava perto do cara e dizia assim, em altos berros: - Tatsuya Nakadai é o melhor ator do mundo! [risos] Mas tempos depois eu acabei ficando muito amigo do Biáfora, era coisa de moleque mesmo, embora a gente gostasse, fosse fã do cara, a jogada era provocar mesmo [risos].

Como se relacionavam os diferentes grupos de apreciadores de cinema japonês? Havia interação entre os públicos nikkei e não-nikkei? A despeito da diversidade de significados atribuídos aos filmes por alguns dos antigos freqüentadores dos cinemas da Liberdade, 
relacionada às diferenças de idade, de interesse, de gênero, de gostos estéticos e de posições políticas, como se tentou demonstrar neste capítulo, haviam significados mais gerais, isto é, para além das particularidades pessoais, atribuídos à experiência de freqüentar esses cinemas? Essas questões serão observadas de perto no último capítulo. 


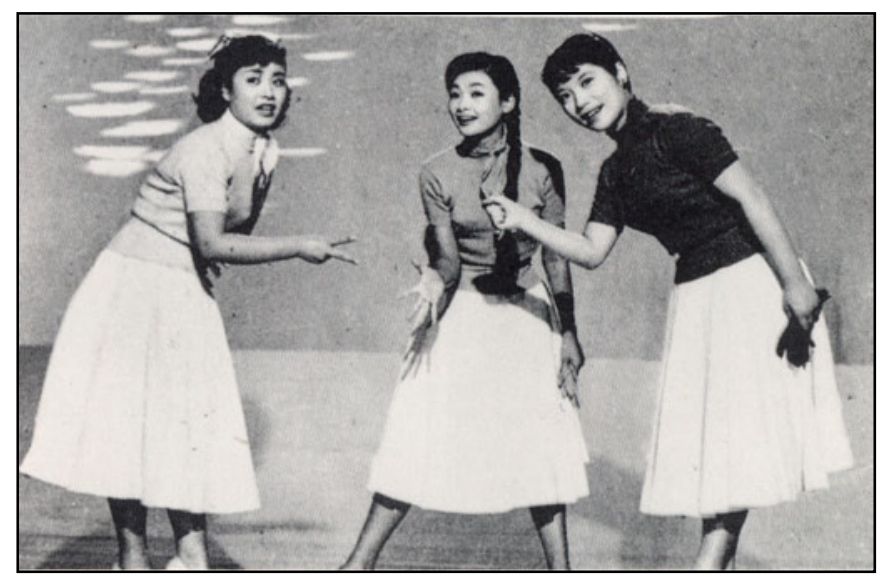

Fig. 17: Misora Hibari, Yukimura Izumi e Eri Chiemi em Janken musume (1955), um dos filmes da série produzida pela Toho com as três estrelas da música japonesa (acima). Fig. 18: Estátua de Tora-san, personagem da série É triste ser homem (Otoko wa tsurai yo) interpretado por Kiyoshi Atsumi, em Tóquio (ao lado).
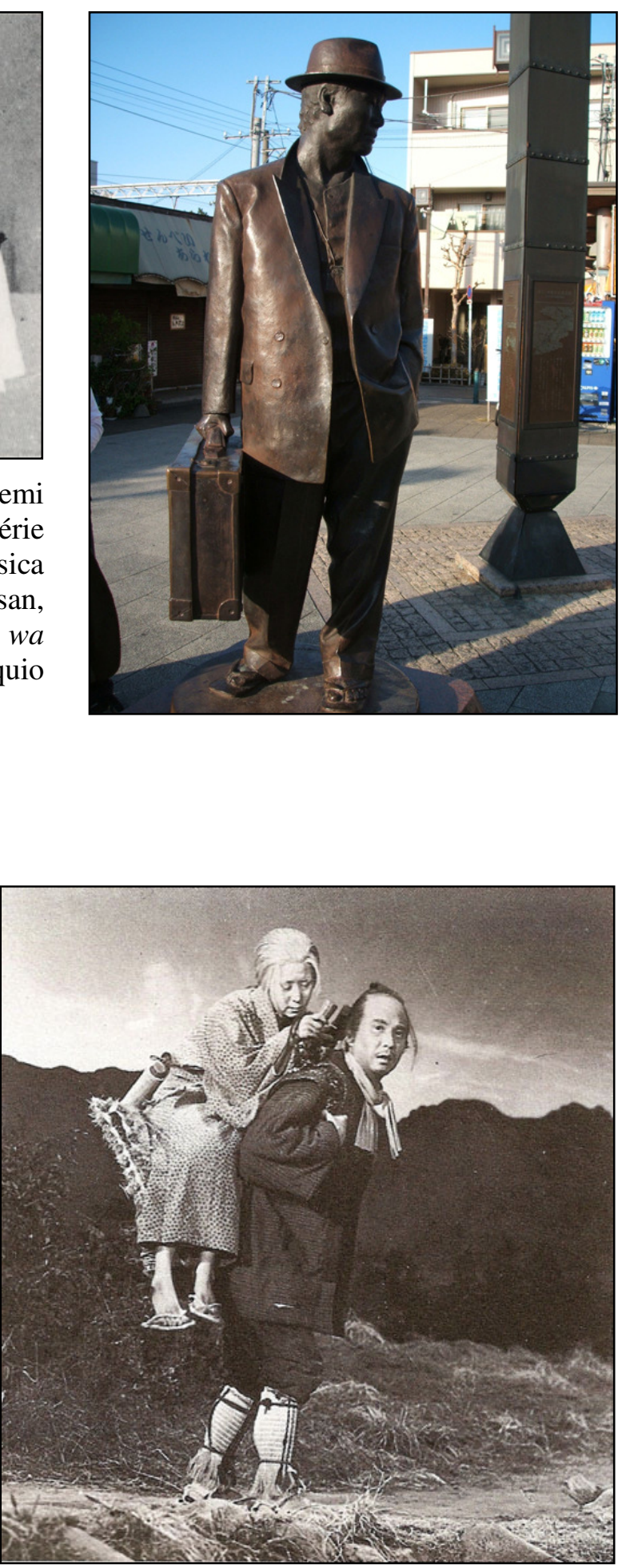

Fig. 19: Cartaz de A dançarina de Izu (1954), segunda adaptação do romance de Yasunari Kawabata, dirigido por Yoshitaro Nomura, com Misora Hibari (ao lado). Fig. 20: A primeira versão para o cinema de A balada de Narayama (1959), dirigida por Keisuke Kinoshita (acima). 


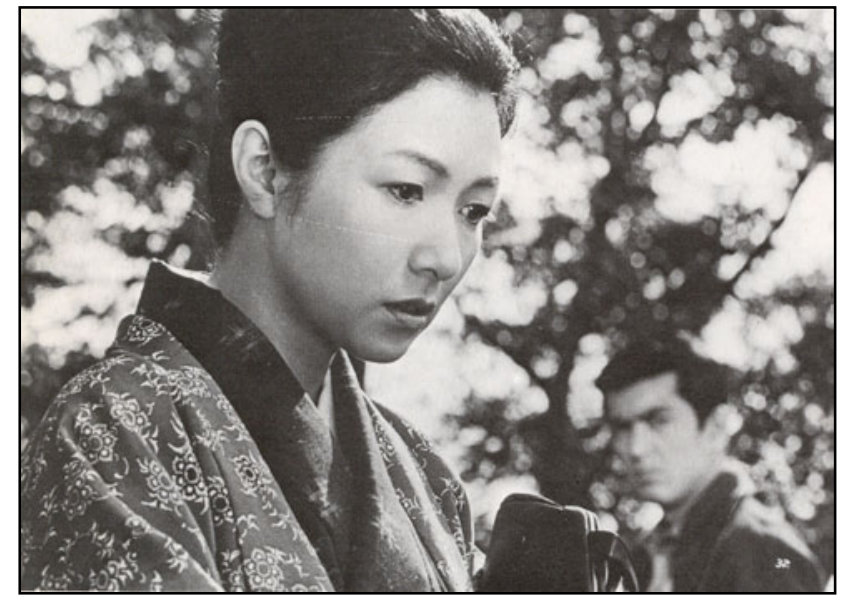

Fig. 21: A atriz Hideko Takamine (acima).

Fig. 23: Toshiro Mifune em Rashomon (1950), dirigido por Akira Kurosawa para a Daiei e exibido em São Paulo em 1952 no Cine Odeon e no Cine Ipiranga (abaixo).

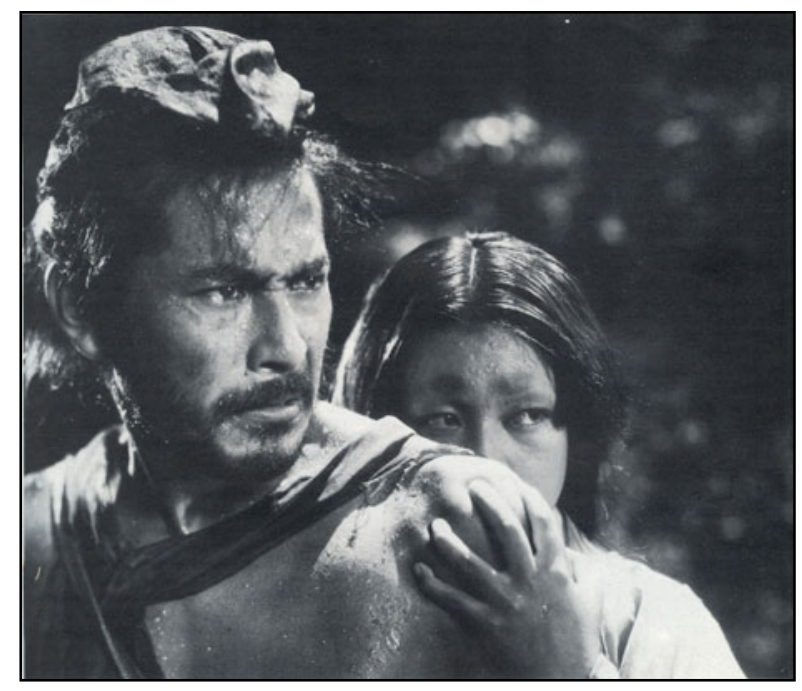

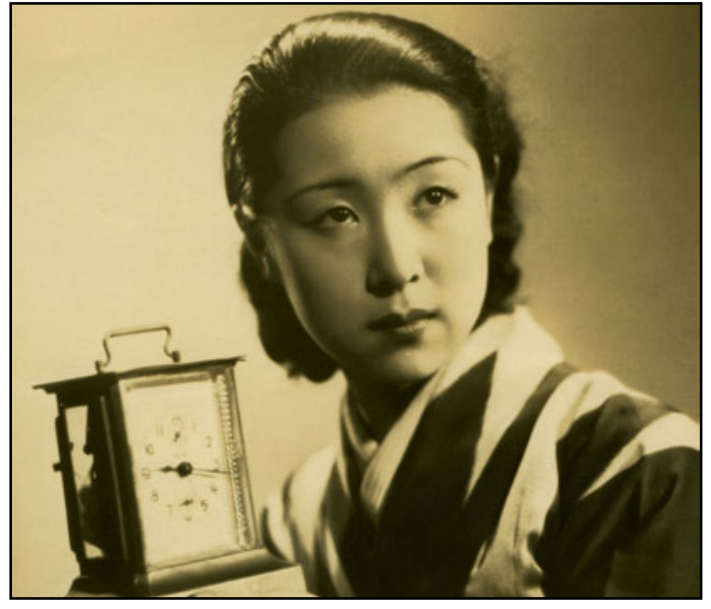

Fig. 22: A atriz Kinuyo Tanaka (acima).

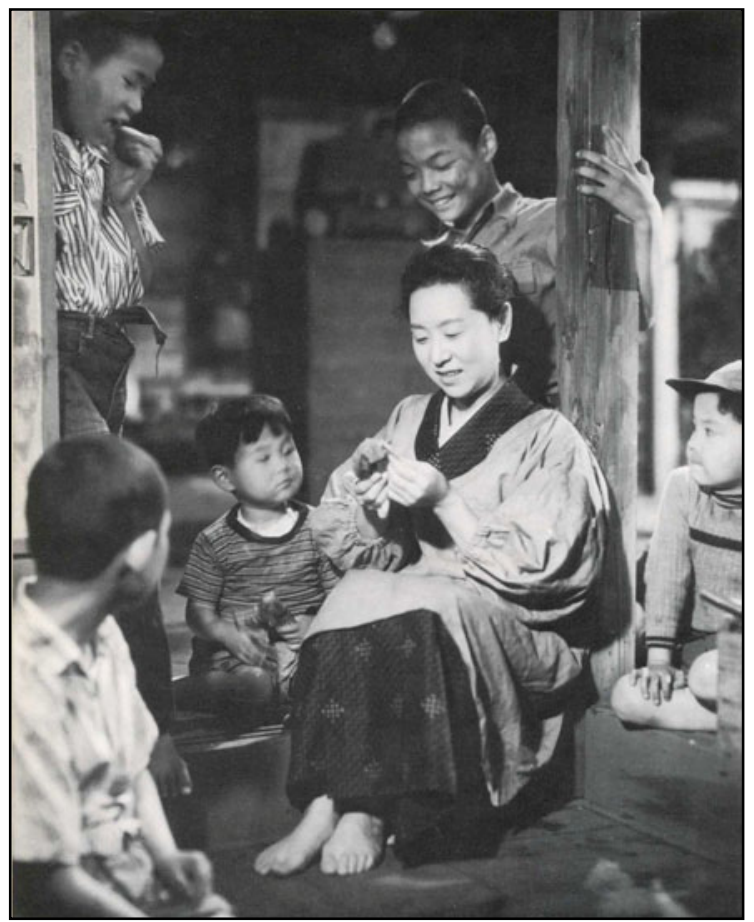

Fig. 24: Mamãe (Okasan, 1952), gendaigeki (drama contemporâneo) dirigido por Mikio Naruse e exibido no Cine Niterói (acima). 
Fig. 25: O homem do riquixá (1958), dirigido por Hiroshi Inagaki. Vencedor do Leão de Ouro do Festival de Veneza, exibido em São Paulo em 1959, no Cine Marrocos e no Cine Picolino (abaixo). Fig. 26: Viver (Ikiru, 1952), de Akira Kurosawa com Takashi Shimura (ao lado).
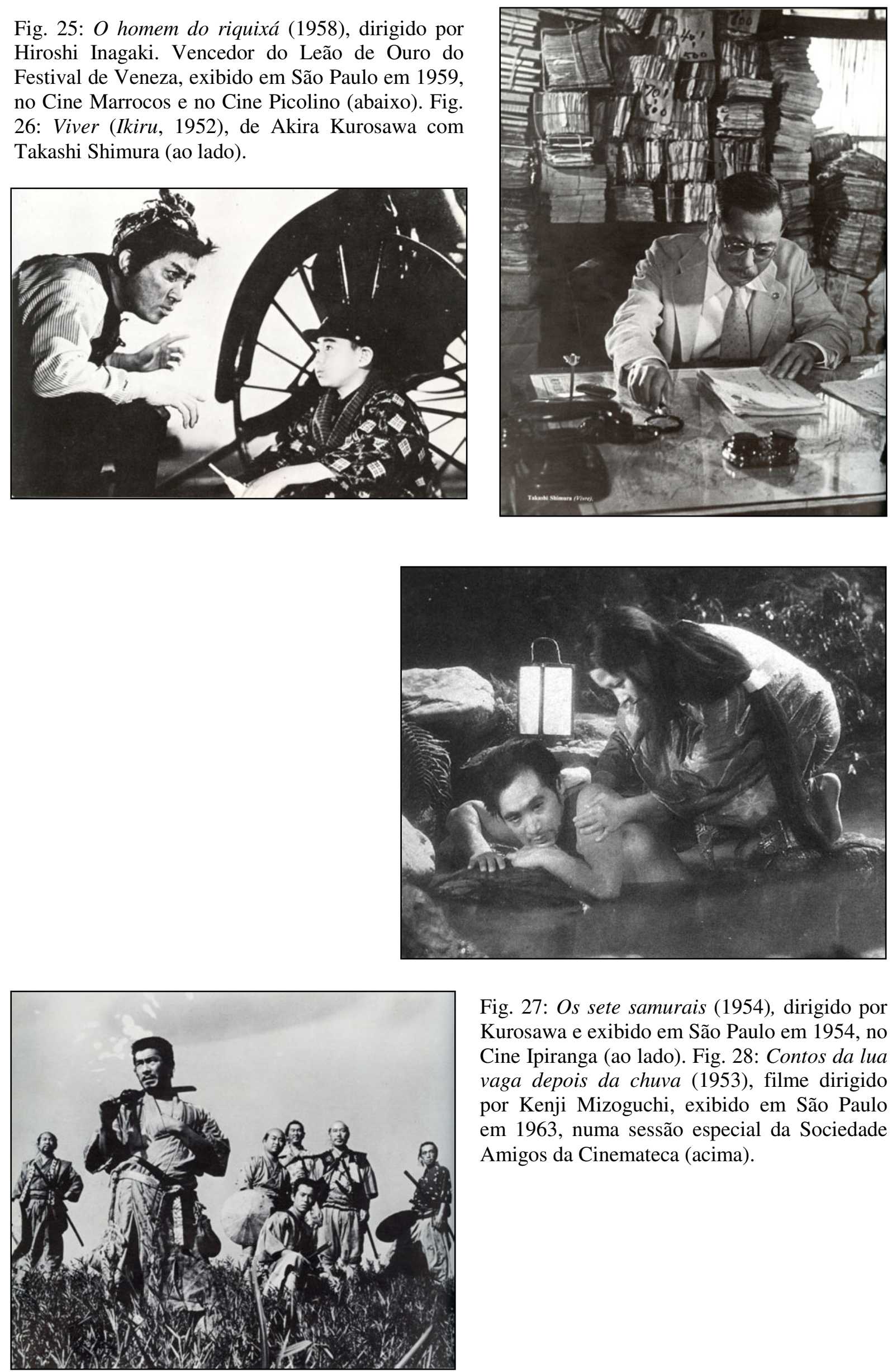

Fig. 27: Os sete samurais (1954), dirigido por Kurosawa e exibido em São Paulo em 1954, no Cine Ipiranga (ao lado). Fig. 28: Contos da lua vaga depois da chuva (1953), filme dirigido por Kenji Mizoguchi, exibido em São Paulo em 1963, numa sessão especial da Sociedade Amigos da Cinemateca (acima). 


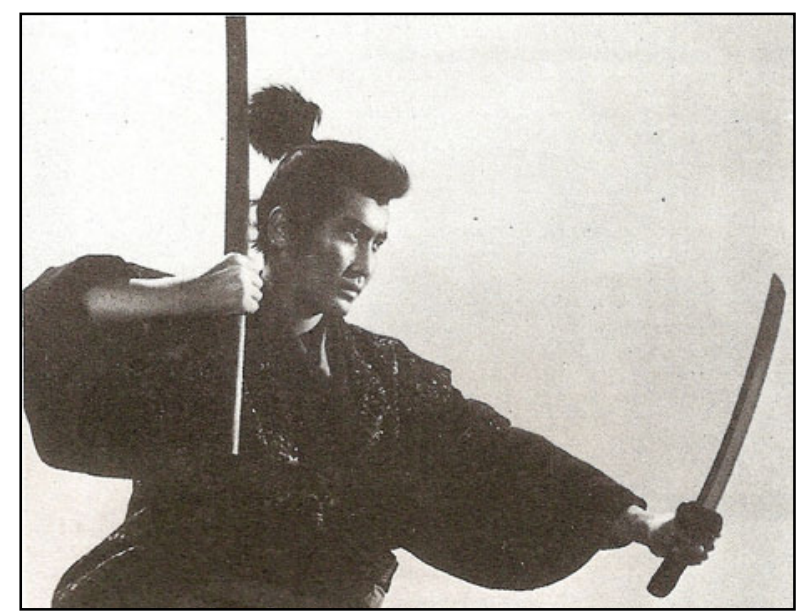

Fig. 29: Miyamoto Musashi (1961-1965), série de cinco filmes dirigidos por Tomu Uchida, com Kinnosuke Nakamura, exibidos em São Paulo no Cine Niterói, entre 1961 e 1966 (acima). Fig. 30: Miyamoto Musashi (1954-1956) versão de três partes da Toho dirigida por Hiroshi Inagaki (ao lado).

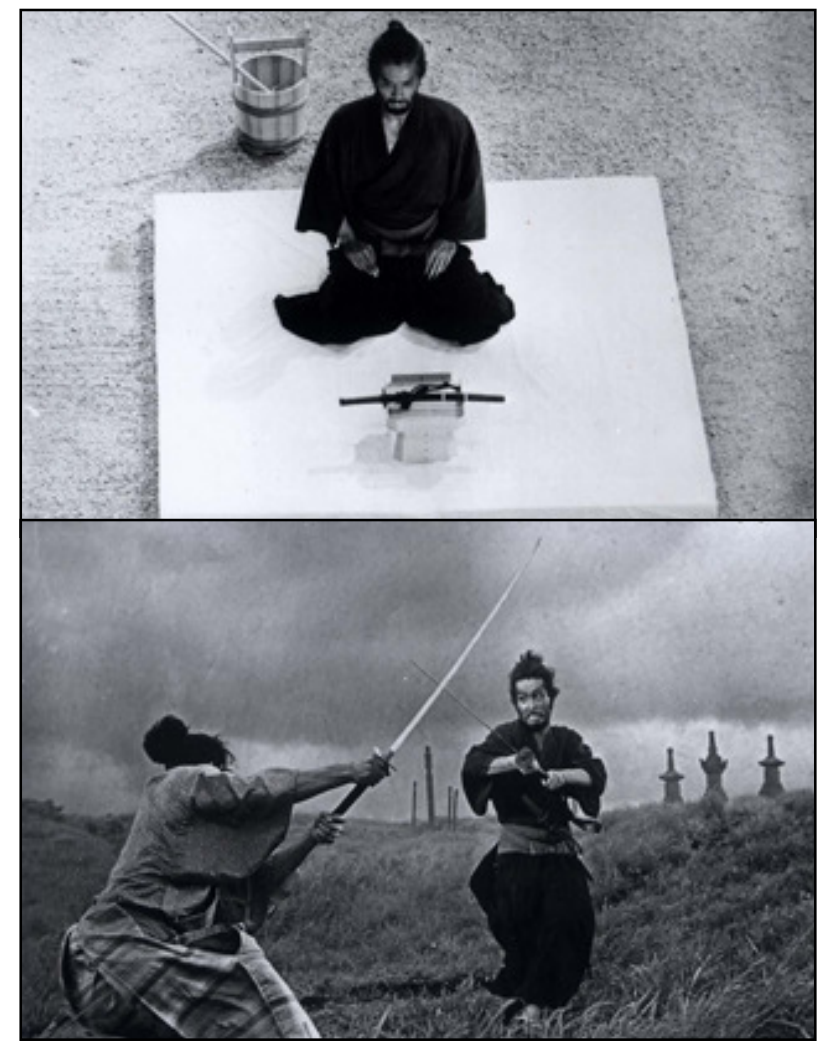

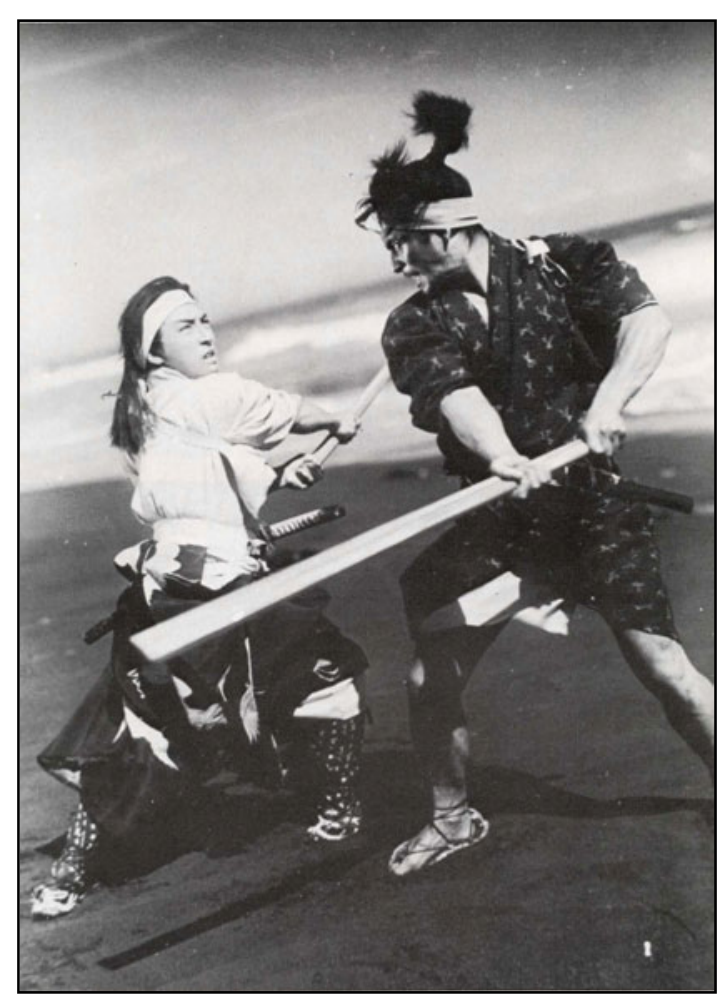

Fig. 31: Harakiri (1962), dirigido por Masaki Kobayashi para a Shochiku (ao lado). Fig. 32: O ator Tatsuya Nakadai em Guerra e humanidade (1959-1961), épico de Kobayashi com 10 horas de duração (abaixo).

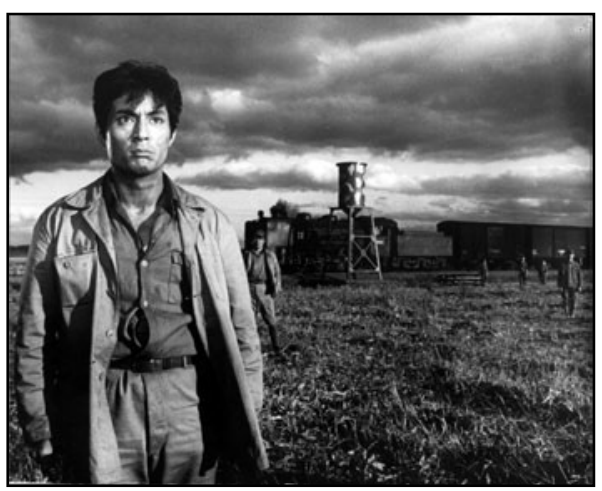




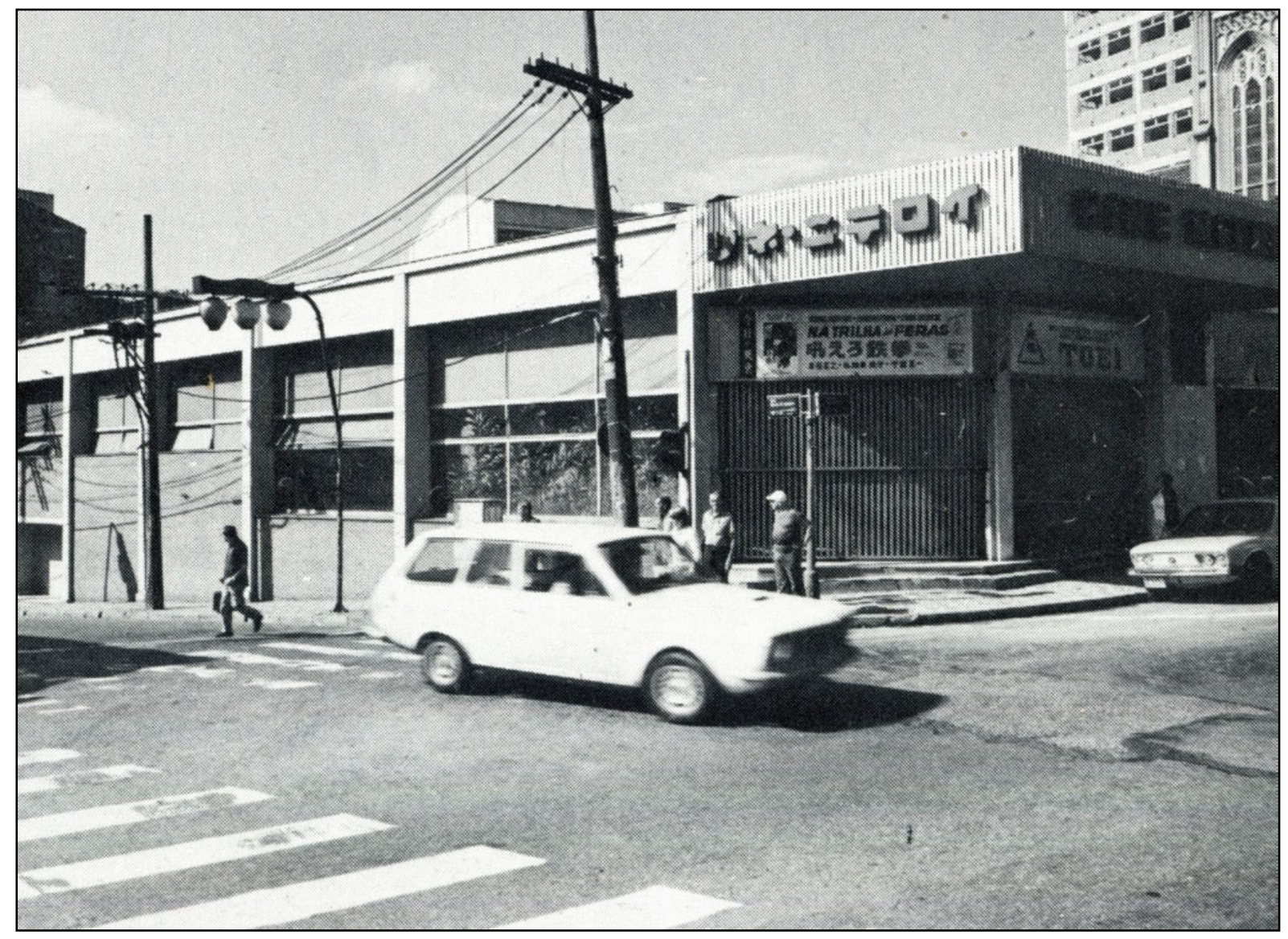

Fig. 33: Fachada do segundo Cine Niterói, localizado na esquina da rua Barão de Iguape com a avenida Liberdade, em fotografia de 1984. O cartaz anuncia o filme de Eizo Sugawa, Na trilha das feras (1964). 


\section{O público paulista}

\subsection{O público japonês e nikkei}

\subsubsection{A dimensão trágica da Segunda Guerra Mundial [ruptura]}

Como visto no primeiro capítulo, a eclosão da Segunda Guerra Mundial provocou uma interrupção das atividades de distribuição e exibição dos filmes japoneses nas cidades do estado de São Paulo com concentração de japoneses e descendentes. Essas cidades contavam na época com uma programação constante de cinema japonês a cargo de companhias de distribuição especializadas. Não só as sessões de cinema japonês foram proibidas, como também foram apreendidos os equipamentos de projeção e as cópias de filmes dessas companhias. Na cidade de São Paulo, a retomada das sessões aconteceria de maneira tumultuada, em 1947, em meio aos incidentes do conflito opondo "vitoristas" e "derrotistas". O organizador dessas sessões, Kimiyasu Hirata, recorda-se que a divulgação teve que ser feita através de panfletos e no boca a boca, uma vez que as transmissões de rádio em japonês continuavam proibidas, mesmo com o fim da guerra (Hirata, 1986: 226).

Para Roney Cytrynowicz (2000), a Segunda Guerra, tanto em sua configuração mundial quanto em suas repercussões no Brasil, "deixou uma profunda marca de mortes, dor e sofrimento no interior do grupo japonês, estabelecendo um corte histórico e de memória coletiva", e assim se constituindo como a data-chave trágica de periodização da presença dos imigrantes japoneses em São Paulo (Cytrynowicz, 2000: 28). Se, durante a guerra, o Estado Novo dirigia às classes médias efeitos de mobilização visando incluir esses setores ao seu ideário político, os operários, a população pobre e os imigrantes seriam atingidos por uma intervenção militar direta: os trabalhadores foram tratados como soldados do front interno e os imigrantes, como inimigos da pátria.

O autor argumenta que, a despeito de um certo consenso de que alemães, italianos e japoneses teriam sofrido, igualmente, restrições no país, os imigrantes japoneses foram as principais vítimas entre aqueles considerados súditos dos países inimigos, pois sobre eles recaiu uma violência específica perpetrada pelo Estado brasileiro: "A opressão contra os imigrantes japoneses, diferente do que ocorreu com italianos e alemães em São Paulo, deixa claro que o Estado Novo moveu contra eles - a pretexto de acusações de sabotagem - uma campanha racista em larga escala" (idem, ibidem: 28). Para os japoneses e nikkeis residentes no estado de São Paulo, o front interno significou perseguições, racismo, opressão cultural, fechamento de escolas e de jornais, expulsão de suas casas e desapropriação de propriedades, 
levando a uma violenta desestruturação da comunidade nipo-brasileira e de seus valores culturais.

O que lembram os freqüentadores dos cinemas da Liberdade sobre a época da guerra? Eunice Yokota nasceu na Mooca, em 1941, e lá morou até os 10 anos de idade, quando se mudou para o Tatuapé com a família. Na Mooca, onde seus pais mantinham uma mercearia, Eunice não se lembra de outras famílias japonesas, mas da influência exercida pelo convívio com os italianos, portugueses e espanhóis, mantida até hoje em seus hábitos alimentares. Da época da guerra, ela se recorda das filas, da escassez de pão e do "pão de guerra", episódios que, junto com o uso do gasogênio como combustível, constituíram os principais temas da memória familiar e da memória da cidade em relação à guerra (Cytrynowicz, 2000: 26). Já a imagem evocada por Eunice, dos "camisas negras" circulando pelas ruas da Mooca num caminhão aberto, remeteria a uma memória mais específica da imigração italiana nesse bairro paulistano:

O que eu me lembro é que a gente ficava na fila da farinha para poder fazer pão, macarrão. Não que eu ficasse, mas eu tenho um irmão mais velho que acordava de madrugada e ficava na fila para comprar macarrão, para derreter esse macarrão e depois fazer pão, quer dizer, transformar em farinha. Então, a farinha realmente fazia falta. [...] Como a gente morava dentro da colônia italiana, eu me lembro do movimento que os italianos faziam para arregimentar as pessoas para apoiar a Itália. Eles entravam de caminhão aberto à noite, cantando pelo bairro. Não sei o que é que eles faziam, se era alguma reunião secreta, alguma coisa desse tipo. Todo mundo se vestia de preto, eles eram chamados de camisas negras. Você olhava o caminhão assim cheio, todo mundo com roupas pretas.

Cytrynowicz observa que havia dois "pães de guerra", o oficial, utilizado para mobilizar a população de acordo com os ideais do Estado Novo, e o caseiro, feito a partir da dissolução da massa do macarrão, conforme lembrado por Yokota. O pão de guerra caseiro, assim como a substituição do pão "oficial" pela polenta de milho, são citados como formas de resistência da população frente à ingerência do governo federal sobre seus hábitos cotidianos. O autor argumenta que a escassez de pão em São Paulo não foi provocada pela guerra, mas, ao contrário, a sua falta e as filas para obtê-lo é que trouxeram a sensação de guerra ao cotidiano da cidade:

A mobilização do pão em São Paulo deu-se com o lançamento, por parte do governo federal, de um "pão de guerra", integral e de preço mais barato que o pão feito de farinha de trigo. [...] A fórmula do pão de guerra era baseada em um aumento da extração da moagem do trigo de $70 \%$ para $80 \%$ a $85 \%,[\ldots]$ provocando uma alteração da cor da farinha e um escurecimento do pão. [...] Apesar da mobilização no cotidiano e no discurso que o tornava alicerce uma nação, pode-se dizer que a população impôs uma certa recusa à aceitação do pão de guerra. [...] Como faltasse farinha de trigo, acontecia de as pessoas comprarem pacotes de macarrão e o desmancharem na panela, para utilizar a farinha na confecção do 
pão. Foi esse pão, [...] que superava a escassez, que ficou conhecido no repertório culinário como o "pão de guerra" e não o "pão de guerra" oficial, lançado pelo governo. Pão de guerra, portanto, foi o feito - caseiramente - à base de farinha de trigo e não o mobilizado para a guerra, escuro e com gosto de milho (Cytrynowicz, 2000: 55-57).

De acordo ainda com Cytrynowicz, na memória das classes médias do período da guerra em São Paulo predomina um registro leve, que privilegia pequenas histórias do cotidiano em torno de uma escassez relativa, isto é, que jamais atingiu a dimensão de fome, como ocorreu na Europa. A memória familiar evocada por Eunice Yokota parece encaixar-se nessa descrição. No entanto, ao falar de um episódio da guerra relacionado às trajetórias familiares de seu marido e de um amigo, que residiam ou mantinham negócios na rua Conde de Sarzedas, uma mudança no tom de sua narrativa é perceptível:

Eu acho que no caso o meu marido, que morava na Liberdade, deve ter sentido mais isso [restrições relacionadas à guerra]. Ele me explicou que na época da guerra eles mandaram todo mundo embora de lá. Ele morava na Conde de Sarzedas e teve que se mudar para Vila Mariana, que na época era o fim do mundo. [...] Outro dia estávamos conversando com um amigo nosso que o pai tinha um hotel, onde agora é o palácio da justiça, lá na praça João Mendes. E esse hotel serviu muito de base para os jogadores de beisebol que vinham do interior para disputar campeonatos em São Paulo e ficavam hospedados no hotel dele. E eles tiveram que sair em horas. Deixaram tudo lá, e nunca foram ressarcidos por isso.

Em São Paulo, as primeiras pensões e mercearias japonesas surgiram na rua Conde de Sarzedas em 1914, mesmo ano em que o professor Shinzo Miyazaki cria informalmente a Escola Primária Taisho, a primeira escola dos japoneses na região (Handa, 1987: 169 e 177). Essa rua e seus arredores tornaram-se a principal concentração de imigrantes japoneses na cidade. Cytrynowicz argumenta que o alinhamento do Brasil com os Estados Unidos ajuda a explicar a intensidade das medidas anti-japonesas adotadas aqui, a partir do ataque japonês a Pearl Harbor, em dezembro de 1941, quando os Estados Unidos declararam guerra contra o Japão.

Uma das primeiras medidas tomadas após o rompimento das relações Brasil-Japão, em 29 de janeiro de 1942, foi uma ordem de evacuação das ruas Conde de Sarzedas e dos Estudantes, tendo seus moradores um prazo de dez dias para deixar o local. Muitos imigrantes japoneses continuavam ainda a residir no bairro, como atestam a nova ordem de evacuação expedida oito meses depois da primeira, e a revista policial realizada em fevereiro de 1943 (Cytrynowicz, 2000: 141). Este episódio evidencia a privação de direitos civis ou de cidadania a que foram submetidos japoneses e seus descendentes no Brasil na época da guerra, bem como o isolamento sentido por eles com o fechamento da Embaixada no Rio de Janeiro e do consulado-geral em São Paulo e o retorno do corpo diplomático ao Japão: 
Com o afundamento dos navios brasileiros em fevereiro de 1943, a polícia iniciou as revistas às casas nas redondezas da rua Conde de Sarzedas, evidência de que ainda havia muitos imigrantes habitando o bairro. "Eles costumavam vir em grupos de quatro ou cinco e às vezes havia entre eles pessoas sem identificação. $\mathrm{O}$ objetivo da revista era verificar se havia armas clandestinas ou algum documento revelando que os moradores eram militares ou ocupavam cargos no governo japonês", conta Tomo Handa [...] Nas revistas, os policiais levavam rádio e dinheiro e não havia a quem reclamar. Em 23 de maio de 1943, a polícia confiscou livros e revistas na livraria japonesa Endo, depois também na Oriente, Toyoyoshi e Nambei, e existiram certamente muitas outras operações de opressão e intimidação contra os imigrantes japoneses, cujo registro documental é escasso (Cytrynowicz, 2000: 141-142).

As irmãs Teresinha Kyoko e Clara Myoko Nakayama nasceram respectivamente em 1936 e 1940, na cidade de Registro, em São Paulo. A mãe delas veio ainda criança ao Brasil com os pais, uma das famílias pioneiras na colonização japonesa do Vale do Ribeira. O pai emigrou adulto do Japão, como técnico de sericicultura (criação de bicho-da-seda), casando-se com a mãe delas na mesma cidade. Havia na época um grande instituto de sericicultura na colônia Aliança, no município de Mirandópolis, São Paulo, outra importante região de concentração dos japoneses no estado. De acordo com Clara, seu pai recebeu um convite para trabalhar nessa colônia, e por três anos atuou como instrutor do instituto local. A mudança da família de Registro para lá ocorreu durante a guerra, época em que Clara e Teresinha não tinham ainda 10 anos de idade. Elas se lembram, no entanto, de terem se hospedado numa pensão da rua Conde de Sarzedas e de uma recomendação inquietante dada pela mãe:

O que eu lembro e que me marcou bastante mesmo foi quando a gente veio para São Paulo, eu era pequena ainda e minha mãe falou: - Você não pode falar nihongo [japonês], tem que falar português. Então aquilo para mim era complicado, porque eu não sabia falar português, falava só o japonês. Em casa, só aprendi a falar o japonês. Aquilo me marcou bastante: Você não pode falar japonês. Eu pensava: então eu não posso falar, né? Já que eu só posso falar em português e eu não sei falar, então eu não posso falar. Isso foi durante a guerra, quando a gente ficou lá na [rua] Conde de Sarzedas, que ficamos hospedados numa pensão lá (Clara Nakayama).

Jeffrey Lesser ([1999] 2001) chama a atenção para o intenso debate em torno da imigração japonesa ocorrido em meados da década de 1930, envolvendo intelectuais e políticos brasileiros. Na Assembléia Constituinte de 1933 eram recorrentes os discursos sobre os japoneses, em que os deputados combinavam histórias da imigração e teorias eugênicas para analisar o futuro do país (Lesser, 2001: 213). Os debates ocorriam também em discussões públicas, por meio de artigos e anúncios veiculados em jornais e em livros que circularam na época. Lesser afirma que esses debates reduziam-se a duas posições: os contrários à imigração japonesa usavam argumentos nacionalistas (os japoneses roubam empregos e terras dos 
brasileiros) e racistas (eles irão poluir a nossa raça ou torná-la doentia); enquanto os favoráveis atentavam para o nível de produção agrícola alcançado no país pelos japoneses, o aumento do capital e do comércio exterior, além da necessidade de uma força de trabalho ampla e dócil. A Constituição de 1934 incluiu uma emenda sobre a imigração, baseada na Lei das Origens Nacionais dos Estados Unidos de 1924, tendo como propósito específico a restrição drástica da imigração japonesa (Lesser, 2001: 217). O autor, no entanto, cita duas outras emendas que afetaram, de maneira mais contundente, a vida dos imigrantes japoneses e seus descendentes a proibição do ensino e da imprensa em língua japonesa:

A nova constituição também gerou tensões nas relações do governo japonês com seus colonos. A proibição de que empresas com acionistas estrangeiros publicassem jornais fez que os colonos e os proprietários dos jornais reivindicassem que as autoridades salvassem a imprensa de língua japonesa no Brasil. Uma outra emenda determinava que toda a educação deveria ser em português, o que resultou no fechamento das 185 escolas primárias formalmente estabelecidas, e de cerca de duzentas escolas de fundo de quintal, criadas pelos imigrantes (Idem, ibidem: 218).

A implantação do Estado Novo, em 10 de novembro de 1937, agravou a situação dos imigrantes japoneses e seus descendentes: a retórica nacionalista utilizada por Getúlio Vargas ao decretar a ilegalidade dos partidos políticos, atiçou os grupos nativistas para um ataque feroz aos imigrantes japoneses; a partir de 1938, novos decretos-leis foram expedidos pelo governo federal tendo como objetivo diminuir a influência estrangeira no Brasil, o que Lesser qualifica como campanha pela "brasilidade", e que modificaria substancialmente as dinâmicas de funcionamento das comunidades japonesa e nikkei (Lesser, 2001: 229):

Decretos exigiam que todas as escolas tivessem brasileiros natos como diretores, e que todo o ensino fosse dado em língua portuguesa e incluísse tópicos "brasileiros". O material didático em língua estrangeira foi proibido [...] Isso resultou no fechamento de seiscentas escolas, embora muitas continuassem a funcionar clandestinamente. [...] Falar línguas estrangeiras, em público ou em particular (em templos religiosos, inclusive) ficou proibido (idem, ibidem: 230 e 233).

Roney Cytrynowicz cita Tomoo Handa, para quem as medidas impostas por Getúlio Vargas, como a proibição do ensino de língua estrangeira nas escolas e nos jornais, eram como "se se pedisse o suicídio espiritual de um povo". Handa observa que transmissão da língua estrangeira para os imigrantes era condição sine qua non para a continuidade de seu povo, ao que Cytrynowicz acrescenta: "porque por meio da língua é que se transmitiam valores, como o respeito aos pais e aos mais velhos, que garantiam a própria estrutura econômica da agricultura dos imigrantes, baseada no trabalho de toda a família subordinada 
ao pai-chefe" (Cytrynowicz, 2000: 162). Essas medidas afetaram a comunicação interna dos imigrantes e a educação de seus descendentes: em fins da década de 1930, "cerca de trinta mil filhos de imigrantes estudavam em 486 escolas japonesas. Em 1939, 219 delas foram fechadas e em boa parte desses locais não havia escola pública 'brasileira' próxima" (idem, ibidem: 163). Na época da campanha pela "brasilidade" ou de nacionalização promovida pelo Estado Novo, a posse de documentos, jornais ou livros com caracteres japoneses era considerado um crime de lesa-pátria, assim como o uso da língua japonesa era visto como uma atividade antibrasileira ou um ato traição à consciência nacional:

Mas os milicianos da nacionalidade estado-novista não distinguiam a política belicista ou racista de Tóquio do simples uso da língua japonesa e da direta reivindicação dos imigrantes japoneses de manter sua cultura em solo brasileiro. Tudo o que se referia à cultura japonesa era considerado uma atividade antibrasileira (Cytrynowicz, 2000: 163).

O fato de o estrangeiro vir para o Brasil e educar seus filhos de acordo com seus pensamentos e diretrizes representava tirar do brasileiro o direito de ser brasileiro e era considerado um ato de traição ao movimento de nacionalização, da unificação da consciência nacional (Handa, 1987: 600).

Mesmo após o fim da Segunda Guerra Mundial e a derrocada do Estado Novo, ambos no ano de 1945, os princípios da campanha de nacionalização continuaram a ressoar no ensino público paulista, conforme indica a lembrança de Sedi Hirano acerca da discriminação e do preconceito contra os nikkeis vivenciados numa sala de aula de um Grupo Escolar de Itaquera:

Tinha professores que ensinavam o japonês, tinha uma escola japonesa ${ }^{53}$. Eu comecei a frequientar essa escola em 1947 ou 1948. Mas era a escola da associação dos moradores de Itaquera, uma escola japonesa, ao mesmo tempo em que eu entrei no Grupo Escolar. Como era logo depois da Segunda Guerra Mundial, a professora disse o seguinte: - Você fala mal o português porque está nessa escola [japonesa]. Você não tem que freqüentar essa escola, você tem é que fazer o curso primário direitinho e aprender o português. Eu vou falar com a sua mãe para tirar você da escola. Havia uma grande pressão. Esse negócio de dizer que no Brasil não existe preconceito é bobagem. E você era objeto desse preconceito. Ou muitas vezes, por ser filho de japoneses, na hora da leitura a professora falava que eu tinha lido muito mal, mas na minha sensibilidade eu estava lendo corretamente. Aí qualquer outra moça ou rapaz que lesse tirava uma nota bem mais alta. E eu tirava uma nota bem mais baixa. Mas eu ficava muito revoltado. Eu fui obrigado a sair da escola de japonês. Por isso é que não sei ler, nem kanji, nem hiragana, nem katakana ${ }^{54}$. [...] Eu sei que a fase não foi fácil, porque eu só senti essa questão da guerra, a questão de ser japonês, de freqüentar escola de japonês, quando comecei a freqüentar a escola primária. Havia um preconceito muito grande em relação aos filhos de japoneses e sempre a nossa atenção era chamada: Você está no Brasil, vê se aprende a falar bem o português!

\footnotetext{
${ }^{53}$ A escola japonesa citada por Hirano foi fundada em 1932 pelo professor Koichi Kishimoto, avô do autor desta dissertação, que manteve, no bairro de Pinheiros, uma escola de língua japonesa e internato, o Gyosei Gakuen, que funcionou entre as décadas de 1930 e 1960.

54 Modalidades de escrita da língua japonesa.
} 
Cytrynowicz lança a seguinte questão: a guerra contra os imigrantes japoneses foi promovida apenas pelo governo e por especuladores (incomodados com o sucesso de cooperativas agrícolas de japoneses, como a de Cotia) ou ela tinha também apelo e apoio popular? Ele argumenta que os diversos relatos sobre ataques cometidos contra entidades japonesas, especialmente em cidades do interior do estado, sugerem que eles teriam ocorrido apenas mediante "manifestações dos imigrantes a favor do Japão ou quando da eclosão das ações terroristas da Shindo Renmei, ou seja, quando os grupos de imigrantes assumiram publicamente posições violentas ou abertamente pró-eixo. Fora isso não há registro de mobilização popular antijaponesa" (Cytrynowicz, 2000: 160).

No entanto, o relato de Sedi Hirano, no qual a hostilidade manifesta-se por meio de expressões preconceituosas e xingamentos dirigidos a uma criança de seis ou sete anos de idade, aponta, possivelmente, para a disseminação dos sentimentos antijaponeses em meio à população, talvez como conseqüência de três décadas de discursos contra os imigrantes japoneses ${ }^{55}$, das políticas e campanhas promovidas pelo governo e das notícias caluniosas que circulavam na época:

Muitas vezes eu era chamado de "Japão, cú de pão", ou "Japão, quinta coluna", e eu não sabia por que. Porque a consciência de uma pessoa de seis, sete anos, não é a consciência crítica que temos agora. Mas por que que eu sou "cú de pão"? Por que eu sou "quinta coluna"? Ou "japonês, olho rasgado", "você não enxerga?" Não sei se você já foi chamado dessa forma, mas eu já fui. Ou se você reclama de alguma coisa: "Se você não está satisfeito com o Brasil, vai embora pra sua terra". Isso eu já ouvi várias vezes. Então havia sim esse clima. E dizer que não havia é bobagem. Porque não sei se foi o Egon Schaden, um professor de antropologia, que logo depois da Segunda Guerra Mundial fez uma pesquisa com as normalistas, e aí ele perguntou para essas moças normalistas, não-descendentes de japoneses, se se casariam ou não com japoneses. Mais de $90 \%$ disseram que não se casariam, então o preconceito era recíproco. Essa questão de que os pais que não deixavam, que os pais que proibiam, não é bem assim. Havia preconceito de ambas as partes.

Lesser aponta que, no início da década de 1940, artigos sugerindo que todos os japoneses eram espiões eram comuns: em 1942, os jornais publicavam diariamente notícias sobre espiões japoneses, muitas delas acompanhadas de alegações falsas de que eles atuavam disfarçados de pescadores ou agricultores (Lesser, 2001: 235 e 238). Em abril de 1944, integrantes de grupos como o Seinen Aikoku Undô (Movimento Patriótico da Juventude) e o Tenchugumi (Executores do Castigo de Deus) destruíram plantações de hortelã e galpões de

${ }^{55}$ Jeffrey Lesser descreve a Campanha Anti-Nipônica que ocorreu em meados da década de 1920 da qual participaram Miguel Couto, presidente da Academia Nacional de Medicina, o seu defensor mais articulado, o Dr. Arthur Neiva, microbiólogo que dirigia o Serviço de Saúde de São Paulo e José Félix Alves Pacheco, ministro das relações exteriores de 1922 a 1926, e proprietário do Jornal do Comércio. Couto, Neiva e Pacheco ficaram conhecidos como "Os três heróis da Campanha Anti-Nipônica", e tiveram presença constante nos debates sobre imigração e assimilação que viriam a ocorrer em meados da década de 1930 (Lesser, 2001: 178). 
criação de bicho-da-seda de outros imigrantes japoneses no interior de São Paulo. Esses grupos eram contrários à venda da hortelã e da seda, empregados na produção militar dos países aliados. Ações como essas foram enquadradas como casos policiais e passaram a ocupar as manchetes dos jornais, como exemplos da ação do quinta-coluna contra os interesses do Brasil na guerra: "Em 18 de novembro de 1944, o Correio Paulistano pedia, genericamente, 'Pena de morte para os japoneses', ao noticiar que 'fanáticos amarelos' haviam destruído plantações nas cidades de Marília e Primavera" (Cytrynowicz, 2000: 136). Cytrynowicz afirma que, por mais inverossímil que parecesse a possibilidade de um ataque contra São Paulo, fosse por mar ou por ar, ela era sempre atribuída aos imigrantes japoneses:

A idéia de "invasão japonesa" era disseminada na cidade durante a guerra, segundo o cronista Jorge Americano: "As costas do Brasil estão infestadas de pescadores japoneses. São Paulo está colonizado de japoneses de leste a oeste. Os submarinos alemães já estão rondando a nossas costas". [...] Vê-se nas referências de Jorge Americano a associação imediata entre pescadores japoneses, colonos agrícolas e submarinos alemães. Não há distinção: todo imigrante japonês é visto como inimigo quinta-coluna (Idem, ibidem: 143).

A pesquisa a que Sedi Hirano se refere com estudantes normalistas, foi um inquérito realizado por Emilio Willems em 1940, tendo como tema "distância social entre raças e nacionalidades". ${ }^{56}$ Os questionários foram preenchidos pelos alunos do curso profissional de várias escolas normais do estado de São Paulo, cuja grande maioria era formada por "moças". A pergunta do inquérito não era se as estudantes se casariam ou não com japoneses, como lembrado por Hirano, mas se a pessoa interrogada admitia o português, inglês, italiano, japonês, etc. como membro da própria família pelo casamento. Willems apresenta e comenta o resultado:

Somente 5,62\% de todas as pessoas interrogadas declararam aceitar o japonês como membro da família. Esse resultado, talvez inesperado, somente comporta esta interpretação: existe em São Paulo uma prevenção muito acentuada contra casamentos de brasileiros com japoneses. Resta sabem quem alimenta essa prevenção, pois somente assim poderemos ajuizar-nos da importância desse fato para o rumo que a miscigenação tomará no futuro (Willems, 1948: 100).

Apesar de Willems apresentar um outro quadro mostrando que a prevenção das mesmas pessoas contra judeus, mulatos e negros era mais acentuada ainda, ele observa que a pergunta se referia ao casamento com qualquer pessoa da família, e não apenas com o

\footnotetext{
${ }^{56}$ Nessa época, Egon Schaden era o primeiro assistente do professor Emílio Willems na Faculdade de Filosofia, Ciências e Letras da Universidade de São Paulo, e participou de outra pesquisa realizada em 1941, um inquérito em todas as escolas públicas primárias do estado de São Paulo com $20 \%$ ou mais de japoneses ou descentes de japoneses (Willems, 1948: 7).
} 
interrogado. Caso fosse perguntado se a pessoa aceitava um cônjuge japonês, as porcentagens do quadro seriam, segundo ele, mais baixas ainda. A "aversão recíproca entre os brasileiros e os japoneses" observada por Willems no lado brasileiro, entre as futuras professoras do estado em 1940, é talvez um outro indício de que os sentimentos anti-japoneses haviam de fato se espraiado pela sociedade.

\subsubsection{Pós-guerra: a cisão entre kachigumi e makegumi [crise e sua intensificação]}

Sedi Hirano nasceu na cidade de Araraquara no ano de 1938. Ele descreve seu pai como um japonês diferenciado, meio nômade, o que explicaria a intensa mobilidade da família pelas cidades do interior paulista: "meu irmão mais velho, que já morreu, nasceu em Marília e foi registrado em Pompéia. Eu nasci em Araraquara e fui registrado em Borborema. O meu outro irmão, o terceiro, nasceu em Rio Preto, e foi registrado em Olímpia”. A mãe de Hirano trabalhava na lavoura e, seu pai, como carvoeiro, pedreiro, empreiteiro de obras e depois, como dono de bar. A leitura de uma tese acadêmica levou Hirano a formular uma hipótese sobre o período em que seu pai foi para São Miguel Arcanjo trabalhar de carvoeiro, embrenhando-se no mato. Esse episódio da trajetória de sua família teria relação com o conflito opondo vitoristas e derrotistas:

\footnotetext{
Você sabe que a família japonesa tem por hábito, isso é da cultura japonesa, não contar todas as agruras, todos os problemas que eles enfrentam na vida cotidiana. Mas ao participar da defesa de uma tese de um rapaz, [...] eu estava lendo a tese dele e tinha um depoimento de uma senhora que dizia que na época da guerra e logo depois, devido às correntes vitoristas, os kachigumi, e os makegumi, os derrotistas, vários japoneses foram perseguidos e tiveram que se embrenhar mato adentro. A partir daí que a ficha caiu! Meu pai lia, era uma pessoa de boa formação, ele lia revistas, jornais, gostava de música [em casa tinha muitos discos importados do Japão]. Então acho que ele foi para São Miguel de Arcanjo trabalhar, queimando madeira para fazer carvão e se mete no meio do mato devido a esse clima do pós-guerra, que tinha um grupo de japoneses que achava que o Japão tinha vencido a guerra.
}

Lesser afirma que os jornais em japonês publicados no Brasil desde 1924 desempenharam um papel decisivo para o estabelecimento de uma identidade local. A contribuição desses jornais para o surgimento da etnia nipo-brasileira ocorreu de duas maneiras: notícias de jornais brasileiros que não chegavam ao interior eram incorporadas nesses jornais, abrindo uma janela para a vida da sociedade envolvente; eles concediam também espaço para expressões culturais e artísticas desenvolvidas pelos imigrantes no Brasil, como a poesia (Lesser, 2001: 167 e 168). Cytrynowicz aponta que era por meio da língua e dos jornais que a comunidade mantinha seus laços com o Japão, pois se dizia que 
esses jornais eram feitos com tesoura e cola, a partir de recortes de notícias dos jornais japoneses. Outro aspecto importante é que esses jornais divulgavam as atividades dos clubes dos imigrantes (kaikan), reportavam notícias locais, além de publicar cotações de produtos agrícolas e anúncios de lojas especializadas (Cytrynowicz, 2001: 164).

Para Cytrynowicz, a proibição da publicação de jornais em língua japonesa provocou o isolamento dos imigrantes, não apenas do Japão, como também do próprio Brasil, uma vez que esses jornais eram possivelmente o único meio de ter notícias locais. $\mathrm{O}$ impedimento ao ensino da língua nas escolas e da circulação de jornais em japonês provocou graves dissensões internas na comunidade, que, segundo este autor, perduraram pelo menos por dez anos após o fim da Segunda Guerra Mundial (Idem, ibidem: 163). Foi nesse contexto que, ao final da guerra e após a rendição do Japão, os imigrantes japoneses no Brasil se dividiram entre os derrotistas (makegumi), que aceitaram a derrota militar do Japão e a derrocada de valores como o culto divino ao imperador, e os vitoristas (kachigumi) ou não-conformados, que mantinham a crença na infalibilidade do imperador e na invencibilidade do Japão, recusandose a aceitar as notícias da derrota desse país (Idem, ibidem: 28 e 164).

Jeffrey Lesser observa que diversas razões fizeram com que a idéia da derrota do Japão tivesse pouca repercussão entre os imigrantes e seus filhos residentes no meio rural: a influência das idéias do Ministério da Educação japonês por meio dos livros didáticos empregados tanto na formação dos imigrantes no Japão, quanto dos nikkeis nas escolas de língua japonesa no Brasil; a proibição da circulação de jornais em língua japonesa; e o fato de que os imigrantes e descendentes não terem assistido aos documentários cinematográficos sobre a rendição do Japão, não porque não tivessem acesso ao cinema, como argumenta o autor, mas porque a atividade de exibição itinerante de filmes estava proibida na época (Lesser, 2001: 240-241).

Marina Narahara nasceu no bairro paulistano Santa Cecília, em 1946. Como mencionado no capítulo anterior, o pai e os avós dela tinham uma loja de móveis numa rua do bairro, mantendo nos fundos uma pequena fábrica-marcenaria. Na época de sua infância, havia algumas famílias japonesas residindo no bairro, tanto que ela se lembra de pessoas que faziam, de forma caseira, produtos da culinária japonesa como o mochi e o tofu, e nas manhãs das sextas-feiras iam vendê-los nas casas das famílias japonesas do bairro. Os filhos dessas famílias formavam a turma de amigos de Marina: na infância, brincavam juntos no bairro e mais tarde, na adolescência, freqüentaram os cinemas da Liberdade. No pós-guerra, Marina era ainda criança, no entanto, um reencontro com uma antiga vizinha, participante daquela turma de amigos, traz à tona uma história daquela época: 
Pelo menos eu não lembro de passar por dificuldades em relacionamentos com pessoas, nunca tive dificuldades assim. Porque do pós-guerra mesmo, a guerra terminou em 1945, eu nasci em 1946, e depois de seis anos já tinha passado aquela fase. Não, mas tinha aquele negócio de kachigumi [vitorista] e makegumi [derrotista]. Eu tenho uma vizinha, que era vizinha na época e acabou sendo vizinha agora [ela mora aqui perto], ela era a mais onechan da turma, era a mais velha da turminha, então ela lembra muito daquela época, e ela fala que o pai dela era kachigumi. Era assim, ele veio do Japão, querendo ficar só um ou dois anos e depois voltar, ele tinha essa imagem do Brasil, veio só para ganhar dinheiro e voltar. Daí aconteceu a guerra e não pôde voltar. E o meu avô, ao contrário, era makegumi, ele acreditava mesmo na derrota do Japão.

A família dessa amiga de infância morava ao lado da família de Marina, em Santa Cecília, e mantinha uma loja de brinquedos. Embora eles tivessem posições contrárias, o avô de Marina e o pai da vizinha eram muito amigos e se encontravam todas as tardes para jogar go. Apesar de não discutirem esse assunto, as duas famílias mantiveram, durante esse período, uma relação harmoniosa.

Eunice Yokota, no entanto, relata uma experiência completamente diferente, de separação de famílias e de amigos de infância por causa das posições assumidas no conflito:

A única coisa que eu senti em relação a esse tema, eu pensei um pouco sobre isso em relação a minha família, mas como a gente morava fora da comunidade, o que eu senti no caso é que tinha uma amiga minha que era amiga de família, era uma família que tinha cinco meninas, então era uma beleza, eu me dava muito bem com elas. E chegou um determinado momento em que não nos comunicávamos mais. Foi porque o avô delas era kachigumi [vitorista]. Então, meu pai não quis mais que mantivéssemos amizade com eles. $\mathrm{O}$ que me atingiu foi isso, eu gostava muito das meninas, nos dávamos muito bem, mas chegou um momento que cortou mesmo, e foi por causa disso. [Eles explicaram pra você na época?] Não, meu pai não explicou. Minha mãe é que explicou: - Olha, a gente não pode mais ir lá, nem a eles virem aqui, porque sempre acontece briga. Numa visita social de repente começam a conversar sobre o assunto: - Não, porque perdeu, porque ganhou, porque não é isso. Aí, pra evitar isso, ele já cortou o relacionamento. Como o meu pai tinha essa posição, não deu para manter mais amizade com quem pensava diferente, que virava briga mesmo. Isso foi na década de 1950.

O ex-tradutor de filmes da Toho, Ricardo Gonçalves, interpreta os conflitos opondo os kachigumi e os makegumi como decorrentes da falta de informação, uma vez que todos os canais de comunicação dos imigrantes japoneses haviam sido cortados. Isso deu margem ao surgimento de boatos fantásticos, alguns deles por parte de oportunistas: "Inclusive especuladores da bolsa que tinham papéis japoneses, que com a derrota não valiam nada, espalharam o boato de que o Japão tinha ganhado a guerra, conseguiram passar esses papéis para pessoas ingênuas".

Jeffrey Lesser afirma que as tensões sociais e étnicas suscitadas pelas atitudes antijaponesas levaram alguns membros da comunidade japonesa e nikkei a uma reação à 
ordem pública, tornando-se cada vez mais "japoneses". Essas tensões levaram ao aparecimento de diversas sociedades secretas que combinavam o nacionalismo japonês com o desejo de reforçar o espaço da identidade nipo-brasileira. No Brasil, o culto ao imperador, elemento central da educação japonesa no primeiro quartel do século $\mathrm{XX}$, substituiria o culto aos antepassados como forma de preservação da identidade. Aqueles que não demonstravam explicitamente sua lealdade ao imperador e ao Japão eram estigmatizados por essas sociedades como inimigos ou traidores, e assim, merecedores de punição (Lesser, 2001: 238- 239).

Das diversas sociedades secretas surgidas no Brasil, a Shindo Renmei foi a mais poderosa. Estabelecida em setembro de 1945, tinha como meta o restabelecimento das escolas japonesas e a preservação da língua, da cultura e da religião entre os nikkeis. Em dezembro de 1945, a organização afirmava ter cinqüenta mil filiados que acreditavam que o Japão havia vencido a guerra ${ }^{57}$. Mesmo após a queda de Getúlio Vargas e do Estado Novo a imprensa japonesa continuou proibida. Nessa situação, Lesser enfatiza a importância do monopólio da informação para o crescimento da Shindo Renmei: "As circulares e os jornais clandestinos do grupo eram distribuídos a partir de 64 escritórios distritais, e encontrava uma audiência ávida entre os muitos imigrantes educados para acreditar na superioridade e na invencibilidade do Japão". A idéia de que as notícias da derrota japonesa eram peças de propaganda norteamericana era reiterada em seus jornais semanais (Idem, ibidem: 241-242). O autor descreve o saldo da ação armada da Equipe Especial de Ataque (tokkotai) e o Esquadrão Suicida (kesshitai), cujo objetivo era assinar aqueles que se manifestavam contra o movimento:

Entre março e setembro de 1946, dezesseis esclarecidos foram mortos, incluindo o chefe da seção japonesa do consulado-geral da Suécia e um antigo coronel do exército, que havia sido diretor da Cooperativa Agrícola de Cotia. Trinta makegumi [derrotistas] foram gravemente feridos e centenas de outros receberam ameaças de morte trazendo a marca do Shindo Renmei, uma caveira com ossos em cruz. Muitos cultivadores de seda, de algodão e de hortelã tiveram suas casas e campos destruídos (Idem, ibidem: 244).

Para os brasileiros, esses assassinatos confirmaram seus temores relacionados ao militarismo e à solidariedade étnica dos japoneses, dado que foram interpretados como uma tentativa de desligamento da cultura majoritária (Lesser, 2001: 244). O processo contra a Shindo Renmei começou em abril de 1950 e foi arquivado em agosto de 1958. Cytrynowicz cita o advogado da organização, para quem esse teria sido o maior processo da República pela

\footnotetext{
${ }^{57}$ Roney Cytrynowicz cita dados do livro Uma Epopéia Moderna: 80 anos de Imigração Japonesa para o Brasil (Comissão de Elaboração da História dos 80 anos da Imigração Japonesa no Brasil, 1992), de que a Shindo Renmei teria congregado no pós-guerra vinte mil famílias, somando mais de cem mil pessoas no estado de São Paulo. Para o advogado da organização, Herculano Neves, outras organizações que não cometeram atos violentos mobilizariam outros cem mil integrantes (Cytrynowicz, 2001: 166).
} 
quantidade de indiciados em uma única acusação: cerca de seiscentas pessoas foram acusadas de terrorismo (Cytrynowicz, 2000: 167).

Como visto, esses mesmos incidentes retardaram a retomada das sessões de filmes japoneses na cidade de São Paulo por um ano: em abril de 1946 Kimiyasu Hirata teve a iniciativa de importar o filme Vida de artista (Ruten, 1937), dirigido por Buntaro Futagawa, levando quatro meses para conseguir a autorização federal e do DOPS (Departamento de Ordem Política e Social) para importar e exibir o filme. No segundo semestre de 1946, em meio aos atentados promovidos pela Shindo Renmei, a cópia do filme foi confiscada pelo poder público. Vida de artista foi finalmente lançado em 1947, no Teatro Fênix da Vila Mariana, no Cine Brasil, em Pinheiros e no Cine São Francisco, no largo São Francisco (Hirata, 1986).

\subsubsection{Sessões lacrimais: o cinema como catarse [ação reparadora]}

Eunice Yokota comenta sobre suas primeiras lembranças do cinema japonês: as idas com a mãe às sessões vespertinas do Cine São Francisco, em 1948 ou 1949. Ela comenta que, pelo fato do cinema ser numa dependência da igreja, "uma coisa extra-oficial", não havia um controle rigoroso de idade para entrar na sala. Como as mães não tinham com quem deixar seus filhos, “[...] muita gente ia com nenê de colo e a criança começava a chorar”. Eunice não entendia bem os filmes, porque eram falados em japonês e não havia legendas. Mas em sua lembrança não eram apenas as crianças de colo que choravam, mas todos os presentes naquelas sessões:

As minhas primeiras lembranças de cinema japonês foram na igreja São Francisco, lá no largo São Francisco. Na parte detrás [da igreja] havia um salão paroquial que servia muito bem como cinema porque era grande e tinha as cadeiras, tudo direitinho, como se fosse um cinema. Lá passavam filmes japoneses, só que eu acho que não era assim com regularidade, de repente tinha, de repente não tinha, devia sair nos jornais, e meus pais gostavam muito de cinema. Não sei se eles gostavam porque não existia uma outra forma de ter contato com o Japão, com a cultura japonesa. Mas eles sempre se interessavam muito e me levavam junto. Então, eu me lembro desde sete, oito anos que eu ia nessas sessões, que em geral eram aquelas sessões totalmente lacrimais. Porque eram aqueles filmes tristes, quanto mais tristes melhor. Porque eram sobre a guerra também, que tinha acabado de acontecer, e eram como novelas mesmo, tinham capítulos e capítulos. Tinha um filme que se chamava $A$ mãe, que tinha dez filmes, vinham um atrás do outro. Mas era uma desgraça atrás da outra, uma sessão de choro [risos]. Mas aquilo era catártico para os japoneses. Você ia lá e chorava, chorava todo mundo junto. Então, disso eu lembro muito. Eu lembro que eu dizia pra minha mãe que eu não queria ir, porque os filmes eram muitos tristes. Mas eu acho que ela não tinha com quem me deixar, então ela falava: - Vamos lá! Aí eu tinha que ir. 
Ricardo Gonçalves recorda-se do mesmo efeito de choro causado pelos filmes sobre a Segunda Guerra Mundial nas mães de alguns de seus colegas do colégio Roosevelt na década de 1950: "Isso eu percebi em alguns colegas meus do ginasial, que diziam que as mães choravam quando viam certos filmes de guerra". No entanto, essa mesma peculiaridade percebida por Ricardo nos filmes japoneses, "fazer a gente chorar copiosamente", levou outros colegas nikkeis a detestarem esses filmes: “O cinema japonês é choradeira!” Um destes colegas, que na época do ginásio sentava-se na carteira detrás de Gonçalves, ao saber de seu gosto pelos filmes japoneses, zombava: "Como é que você pode gostar desta porcaria de cinema japonês? Isso não vale nada!”.

A cineasta e pesquisadora Olga Futemma recorda-se também dos filmes sobre a Segunda Guerra Mundial produzidos no Japão e exibidos nos cinemas da Liberdade. Ela se lembra especificamente de um filme com a atriz Hideko Takamine (Fig. 21) no papel de uma mãe que perde o filho que foi lutar na guerra, neste caso, do lado dos Aliados. A atuação de Hideko em filmes como esse marcou Olga a ponto dela prestar uma homenagem à atriz no título de seu documentário sobre a imigrante japonesa e duas gerações de mulheres nikkeis no Brasil, Retratos de Hideko (1981). Assim como Eunice e Ricardo, Olga faz referência à função ou efeito catártico desempenhado pelo filmes japoneses, especialmente aqueles sobre a Segunda Guerra Mundial, que provocavam uma reflexão sobre o papel do Japão na guerra nas conversas de seus pais:

Eu vi muitos filmes sobre guerra, porque houve um trabalho do Japão de produzir muitos filmes sobre a guerra, com uma mensagem em geral humanista, em prol da paz, mostrando mesmo os horrores dela. Eu vi muitos filmes sobre kamikaze, e lembro que eu falava: - Meu deus, de novo é filme de mãe chorando porque o filho ia ser soldado, piloto de avião e não ia mais voltar. Aprendi a buscar os filmes da Takamine Hideko, daí o Retratos de Hideko, porque foi a primeira coisa que me bateu. Tem um filme com ela que se passa no Havaí, ela tem um filho que vai lutar contra os japoneses, porque eles estão no Havaí, território americano, e ele volta doente e morre. Quando ele está já desfalecendo, ela, vestida de maneira muito simples de camponesa, para alegrar o filho começa a dançar um hula-hula, a dança havaiana. Eu não sei hoje como isso bateria pra mim, mas eu achei de uma beleza! É desses filmes que as pessoas que hoje têm a idade que eu tinha, provavelmente vejam esses filmes e falem: - Ah, meu deus, que melodrama! Mas funcionava, porque eu acho que nós éramos espectadores mais inocentes. E fazia bem, pelo menos nas conversas dos meus pais havia uma reflexão do papel do Japão na guerra. Além de ser uma cinematografia inquestionavelmente bela, tinha essa função catártica também, que o pessoal da colônia viveu intensamente. Ninguém pode dizer que não seja uma boa função para o cinema.

A noção de catarse surge na Poética de Aristóteles associada à definição de tragédia: "É, pois a Tragédia imitação de uma ação de caráter elevado, completa e de certa extensão, [...] [imitação que se efetua], não por narrativa, mas mediante atores, e que, suscitando o terror 
e a piedade, tem por efeito a purificação [katharsis] dessas emoções"” (VI, 27 - Aristóteles, 1992, 37).

Em Tempo e Narrativa (1994-1997), ao elaborar uma reflexão sobre este texto de Aristóteles, Paul Ricoeur busca extrair dele um modelo da tessitura da intriga, característico da tragédia, que possa se estender a qualquer composição narrativa.

Ricoeur define o modelo trágico extraído da teoria aristotélica como um modelo de concordância discordante e não como puramente concordância. No centro dele residiria o fenômeno da ação trágica que Aristóteles denomina de "inversão": a passagem da fortuna para o infortúnio, na qual operariam os "incidentes aterrorizantes ou lamentáveis". O lamentável e $\mathrm{o}$ aterrorizante seriam qualidades ligadas às mudanças de sorte mais surpreendentes e orientadas para a infelicidade. Ricoeur cita uma corrente de comentadores da obra de Aristóteles (Else, Dupont-Roc e Lallot), para a qual a resposta emocional do espectador seria construída no drama, na qualidade dos incidentes destruidores e dolorosos para os próprios personagens, de forma que a catharsis seria operada pela própria intriga (Ricoeur, 1994: 72). $\mathrm{O}$ sentimento de terror seria dirigido à infelicidade de um semelhante, enquanto que o de piedade, ao homem que não mereceu essa infelicidade.

A catharsis seria uma depuração que teria o espectador como sede, consistindo na transformação da pena inerente aos sentimentos de piedade e de terror em prazer, o prazer do reconhecimento, isto é, o prazer de aprender. Essa transformação alquímica subjetiva seria também construída na obra: incidentes lamentáveis ou aterrorizantes são levados à representação poética pela construção de um enredo ficcional. A intriga tenderia a tornar necessários e verossímeis esses incidentes discordantes, depurando-os: "É incluindo o discordante no concordante que a intriga inclui o comovente no inteligível" (Idem, ibidem: 74). Essa é uma das maneiras pelas quais Ricoeur estabelece relações entre a experiência viva, na qual a discordância dilacera a concordância, e a construção do enredo ficcional, no qual a concordância repara a discordância.

Seria possível pensar os (melo)dramas japoneses sobre a guerra citados por Eunice, Ricardo e Olga, e a catarse provocada por eles em salas de cinema japonês em São Paulo, nos termos desse modelo trágico de tessitura da intriga?

Há, por um lado, conforme lembrado por Olga e visto no capítulo anterior, o esforço de diversos cineastas japoneses de elaborar representações cinematográficas sobre episódios relacionados à guerra, abordando questões como a dor impingida pela perda de familiares, ou refletindo criticamente sobre alguns valores tradicionais, como a obediência incondicional à hierarquia e o militarismo. 
No Brasil, por outro lado, os imigrantes e seus descendentes, privados de seus meios de comunicação próprios e passando por outras experiências trágicas, discordaram violentamente entre si com relação à situação real do Japão ao final da guerra. Por meio dos filmes eles puderam enfim reconhecer a condição contemporânea do Japão, assim como tomar contato com a reflexão dos próprios japoneses acerca da guerra, suas causas e conseqüências. Puderam ainda refletir sobre a própria condição de imigrante [e de descendente] no Brasil, sobre as posições tomadas no conflito do pós-guerra e sobre a possibilidade de retorno ao Japão. Nos filmes, no entanto, essa aprendizagem era realizada essencialmente por meio das emoções, daí a lembrança do choro.

\subsubsection{Hipótese: o cinema como meio de reconciliação [desfecho]}

Jeffrey Lesser levanta dois fatores atuantes na marginalização dos grupos de kachigumi [vitoristas] depois de 1947: a mobilização para a arrecadação de donativos para as vítimas japonesas da guerra, que criou grupos de "simpatizantes" ou de "linha-dura" que, embora reconhecessem a derrota do Japão, assumiam a posição de que assuntos familiares não deviam ser discutidos com a sociedade envolvente; e a vinda ao Brasil do campeão olímpico de natação Masanori Yusa e sua equipe, os Peixes Voadores, no início dos anos 1950, que foi recebida com entusiasmo pelos japoneses e nikkeis no estado de São Paulo.

De acordo com Tomoo Handa, a equipe de natação chegou à cidade de São Paulo em março de 1950, seguindo depois para Ribeirão Preto e Marília ${ }^{58}$. Em São Paulo, os Peixes Voadores apresentaram-se no estádio do Pacaembu, no XVII Campeonato Brasileiro de Natação, para um público numeroso com o predomínio dos japoneses e nikkeis. Handa descreve o impacto da cerimônia de abertura da competição, em que o próprio governador do estado de São Paulo hasteou a bandeira japonesa enquanto o Kimigayo, o hino nacional japonês era executado, duas práticas proibidas e consideradas antibrasileiras por quase uma década:

No momento seguinte, quando o silêncio havia retornado ao estádio, eis que as mãos do governador começaram a hastear a bandeira japonesa e, quase ao mesmo tempo, fizeram-se ouvir os acordes do Kimigayo. Há quanto tempo não ouviam aquele saudoso hino! Agora ecoava lenta e sonoramente no silêncio da noite, que cobria o vale do Pacaembu. Naquele

\footnotetext{
${ }^{58}$ A mãe do autor desta dissertação conta que no período do pós-guerra a família morava na região da Alta Paulista e o seu avô paterno era um simpatizante dos kachigumi [vitoristas], isto é, ele não acreditava nas notícias sobre a derrota do Japão na Segunda Guerra Mundial. Um de seus filhos o levou à cidade de Marília, por ocasião da visita dos Peixes Voadores à cidade, onde ele ouviu um dos nadadores, aos prantos, afirmar que o Japão havia realmente perdido a guerra. Foi apenas a partir deste episódio que ele se convenceu do fato.
} 
momento o Kimigayo penetrava fundo no âmago das milhares de pessoas ali presentes [...] Podiam ser ouvidos choros silenciosos dos japoneses em todos os cantos do estádio. Todos - também os nadadores e os brasileiros - se fundiam na tempestade daquele grandioso momento. Ali não havia fronteiras, nem diferenças de raça (Handa, 1987, 748).

Lesser, no entanto, relata uma história envolvendo a mesma equipe de natação, reveladora dos métodos da Shindo Renmei e que contribuiu para a marginalização dessa organização:

Durante uma entrevista, os integrantes dos Peixes Voadores mostraram-se chocados com a idéia apresentada a eles, de que o Japão havia vencido a guerra. Como resultado a Shindo Renmei e a Zenpaku Seinen Renmei lançaram uma campanha contra os nadadores, espalhando cartazes que diziam que eles eram coreanos fingindo-se de japoneses. Tanto os nikkeis quanto os japoneses ofenderam-se com essa sugestão, e o fato de o governo brasileiro ter indiciado mais de dois mil integrantes da Shindo Renmei foi recebido com alívio (250).

Entre os fatores que levaram à reconciliação entre os kachigumi e os makegumi, Ricardo Gonçalves salienta a visita ao Brasil, em 1952, do grão-mestre da comunidade budista na qual atua até hoje, a Higashi Honganji. O fato de o grão-mestre ser ligado por casamento à família imperial japonesa constituiu um motivo de interesse maior pela visita, em vista do culto da família imperial por parte dos imigrantes. Nas diversas colônias japonesas nas quais circulou, nos estados de São Paulo e Paraná, o grão-mestre encontrou-se com lideranças dos dois grupos, atuando para a reconciliação deles:

1952 foi o ano em que as missões budistas vieram para cá. Foi o ano em que nasceu a comunidade em que eu atuo hoje, que é o Higashi Honganji. Nasceu com uma visitação feita ao Brasil pelo seu grão-mestre, que era um personagem que tinha um status muito peculiar porque era ligado por casamento à família imperial, e a colônia sempre idolatrou a família imperial. Em 1952, no momento em que se normalizam as relações Brasil-Japão, Higashi Hoganji pensou em promover a vinda do grão-mestre para cá [...] porque se pensou na possibilidade do grão-mestre atuar na linha de reconciliar makegumi e kachigumi. Então foi montada uma comitiva para ele vir ao Brasil, foi estabelecida uma programação em que ele ia visitar as principais colônias no interior de São Paulo e do Paraná e fizeram vários estratagemas para promover a reconciliação. Ele queria reunir-se com os líderes dos dois grupos, kachigumi e makegumi, e a negociação era complicada porque os grupos queriam recebê-lo mas não queriam se encontrar. Então, por exemplo, numa cidade o grão-mestre tinha que almoçar com os kachigumi e jantar com os makegumi. Na hora de hospedar também era complicado, então numa cidade se hospedava em casa de kachigumi, em outra cidade em casa de makegumi e fazendo o possível para reconciliar as facções. Um primeiro passo foi esta viagem.

No processo de reconciliação entre os makegumi e os kachigumi, Ricardo Gonçalves observa também a importância da participação da colônia japonesa nas comemorações do IV 
Centenário da Cidade de São Paulo (1954), por meio de uma comissão colaboradora da colônia japonesa, criada em dezembro de 1952:

Agora o que foi decisivo, pelo menos aqui em São Paulo, foi a festa do IV Centenário, em 1954. Porque aí foi feita uma comissão para os festejos do IV Centenário, com a participação de vários elementos das colônias estrangeiras, a participação italiana foi decisiva, que era o Francisco Matarazzo Sobrinho, o Ciccilo Matarazzo, e formou-se também uma comissão de membros da colônia japonesa e essa comissão foi um marco importante também para apagar estas diferenças entre makegumi e kachigumi.

De acordo com Tomoo Handa, na época a colônia japonesa não possuía nenhuma entidade representativa e centralizadora, isto é, que representasse todas as províncias de origem dos imigrantes. A conturbação da fase do pós-guerra não havia sido ainda de todo superada e havia um descompasso entre a colônia japonesa e o consulado japonês, reaberto com o reatamento das relações diplomáticas entre o Brasil e o Japão.

Apesar das dificuldades relatadas para a instalação da comissão e os conflitos envolvendo os integrantes iseis [da primeira geração] e o deputado nissei Yukishige Tamura, a colônia japonesa conseguiu alcançar o que Handa qualifica como o seu "primeiro resultado positivo em termos de união, [...] entregando à população de São Paulo, com as contribuições arrecadadas de 45 mil famílias japonesas de todo o Brasil, o Pavilhão Japonês, um espaço de exposição e um jardim japonês, todos no Parque do Ibirapuera" (Handa, 1987: 756). Ele destaca a ajuda dos vitoristas, que se imaginava que não fossem colaborar.

Durante os dois anos e meio de atuação, essa comissão elaborou um plano para a fundação de um órgão central de contato dos imigrantes japoneses radicados no Brasil. Como visto no primeiro capítulo, em outubro de 1955 ocorreu no Teatro Nanbei, também conhecido como Cine Tokyo, a assembléia de dissolveu a comissão em prol do IV Centenário e instalou a comissão organizadora da Sociedade Paulista de Cultura Japonesa, conhecida atualmente como Sociedade Brasileira de Cultura Japonesa, o Bunkyo (idem, ibidem: 762).

Em 1952, no entanto, a situação não havia ainda se normalizado. Cytrynowicz cita dados de uma pesquisa realizada por Seiichi Izumi indicando que, num total de 448 entrevistados nos estados de São Paulo e Paraná, 14,5\% eram "esclarecidos" (aceitaram a derrota), 56,9\% eram "duros" (não a admitiam abertamente) e 28,6\% eram "fanáticos" (acreditavam na invencibilidade do Japão) (Cytrynowicz, 2001: 165).

A hipótese que se segue é a de que as exibições públicas dos filmes japoneses no pósguerra - sejam aquelas promovidas pelas companhias de distribuição e exibição itinerante no Cine São Francisco, em bairros paulistanos e em cidades do interior paulista, sejam as sessões 
regulares no Cine Niterói, inaugurado em 1953, e no Cine Tokyo, surgido no ano seguinte desempenharam um papel decisivo para a reconciliação dos imigrantes japoneses e seus descendentes no estado de São Paulo ${ }^{59}$.

Um primeiro indício a favor dessa hipótese é a grande popularidade alcançada por essas sessões - Kimiyasu Hirata relembra do sucesso da estréia do filme Vida de artista no Cine São Francisco: "As filas chegavam quase a um quilômetro" (Sociedade Brasileira de Cultura Japonesa, 1986). De acordo com José Fioroni Rodrigues, a exibição desse filme alcançou um grande sucesso de público (Kobayashi, 2005: 17).

Osvaldo Tanaka, filho do fundador do Cine Niterói, Yoshikazu, comenta que, na fase áurea dessa sala, de 1953 a 1963, até cinco mil pessoas passavam pela borboleta do cinema nas sessões aos domingos (Moribe, 1991). Quinze anos depois ele observa que dependendo do filme, o público chegava a 25 mil por semana (Kobayashi, ibidem: 27). Olga Futemma descreve o movimento dos quatro cinemas da Liberdade nos finais de semana: "Na década de 1960, a presença do cinema japonês se consolida: quatro salas, todas no bairro da Liberdade, com uma oferta total de aproximadamente quatro mil poltronas, e as casas lotavam nos finsde-semana" (Futemma, 1986: 79).

Mais do que pelas estimativas do público que freqüentava as exibições de filmes na Liberdade, o papel desempenhado por esses cinemas para a reconstituição da sociabilidade ${ }^{60}$ dos japoneses e dos nikkeis no bairro pode ser avaliado pelo consenso acerca da importância do surgimento do Cine Niterói para a formação do comércio japonês na região da rua Galvão Bueno e da praça da Liberdade, presente tanto em pesquisas acadêmicas quanto em relatos de comerciantes do bairro. Como visto no primeiro capítulo, o estabelecimento do Prédio Niterói é indicado por Sachio Negawa (2000) como o primeiro dos três eventos determinantes para a formação da Liberdade como bairro japonês, seguido da inauguração do prédio do Bunkyo, em 1964, e da abertura da estação de metrô Liberdade em 1975.

Outro indício da atuação das sessões de cinema japonês em favor da reconciliação dos japoneses e nikkeis do estado é efeito catártico produzido pelas exibições de filmes sobre a Segunda Guerra Mundial na cidade de São Paulo. José Fioroni Rodrigues recorda-se do primeiro filme "novo" trazido no pós-guerra, A volta dos cinco camaradas à Tóquio (Tokyo gonin otoko, 1945) exibido no Cine São Francisco em 1948: “A fita foi feita em 1945 e

\footnotetext{
${ }^{59}$ Isto é, junto com os outros episódios citados: a ajuda às vitimas da guerra no Japão, a visita dos Peixes Voadores e do grão-mestre da Higashi Honganji, e os trabalhos da Comissão do IV Centenário.

${ }^{60} \mathrm{O}$ uso do conceito de sociabilidade corresponde à formulação de Georg Simmel, tal como descrita por Frúgoli (2007): “ um tipo ideal entendido como "social puro", forma lúdica e arquetípica de toda a socialização humana, sem quaiquer propósitos, interesses ou objetivos que a interação em si mesma, vividas em espécies de jogos, nos quais uma das regras implícitas seria atuar como se todos fossem iguais" (Frúgoli, 2007: 9).
} 
mostrava Tóquio arrasada, quase sem casas, tudo em destroços. Mas o interessante é que foi feita em tom otimista, era uma comédia" (Kobayashi, 2005: 18). Uma comédia que focalizava as atribulações de cinco ex-combatentes no imediato pós-guerra - conforme escreve ele em 1995 (Rodrigues, 1995: 166).

A pesquisa anteriormente citada, realizada em 1952 por Seiichi Izumi com os imigrantes e nikkeis residentes em São Paulo e no Paraná revela que, ao final da guerra, apenas 3,3\% dos entrevistados receberam notícias sobre o seu término por revistas e jornais brasileiros, $23,9 \%$ o fizeram por transmissão de rádio do Japão, de forma direta ou indireta, e 24,1\% por meio de cooperativas e outras associações japonesas (Cytrynowicz, 2001: 165). Como visto, os jornais brasileiros mal chegavam aos japoneses e nikkeis residentes no meio rural. Além disso, as notícias sobre a derrota do Japão no fim da guerra, veiculada por esses jornais, foram interpretadas por uma parte significativa dos imigrantes japoneses e nikkeis como propagandas brasileira e norte-americana, devido tanto à campanha promovida pela Shindo Renmei, quanto pelo tratamento hostil e calunioso dispensado por alguns desses jornais aos japoneses e seus descendentes durante a guerra.

Nos episódios relacionados às apresentações da equipe de natação japonesa no estado de São Paulo e à visita do grão-mestre da Higashi Honganji a São Paulo e Paraná, o que parece ter sido valorizado, além do re-contato dos imigrantes e seus descendentes com símbolos estimados da nacionalidade japonesa como o hino, a bandeira e a família imperial, foi o diálogo estabelecido por eles com respeitados japoneses que estavam no Japão durante a guerra. Eles puderam, finalmente, ouvir dos próprios japoneses, o que se passou com aquele país no epílogo e no desfecho da guerra.

De forma equivalente, com a retomada das exibições dos filmes japoneses no estado de São Paulo, os japoneses e nikkeis voltaram a assistir aos filmes escritos, produzidos e dirigidos pelos próprios japoneses, muitos deles discutindo a guerra, como aquele citado por Rodrigues, além dos filmes comentados no capitulo anterior. Se os episódios relacionados à Comissão em prol do IV Centenário e à visita do grão-mestre da Higashi Honganji envolveram basicamente as lideranças das colônias japonesas do estado de São Paulo, ao cinema japonês iam todos.

A formulação dessa hipótese inspira-se no conceito de drama social, desenvolvido por Victor Turner no livro Schism and Continuity in an African Society, publicado em 1957. Informado pelo estudo dos ritos de passagem de Arnold van Gennep ([1908] 1960), e a partir de sua observação etnográfica nas aldeias Ndembu, Turner elabora o conceito de drama social, tomando como metáfora ou modelo uma forma estética humana: 
Vi pessoas interagindo e, dia após dia, via as consequiências de suas interações. Comecei então a perceber uma forma no processo do tempo social. E esta forma era essencialmente dramática. Aqui, minha metáfora e meu modelo eram uma forma estética humana, um produto da cultura e não da natureza. Uma forma cultural era o modelo para um conceito social científico [...] Uma das características que mais chamam a atenção na vida social dos Ndembu em suas aldeias era a propensão ao conflito. O conflito era uma ocorrência comum entre grupos de aproximadamente duas dúzias de parentes que constituíssem uma comunidade aldeã. Ele se manifesta em episódios de irrupção pública de tensão que chamei de "dramas sociais". [...] Quando os interesses e atitudes de grupos e indivíduos encontravam-se em óbvia oposição, os dramas sociais me pareceram constituir unidades no processo social isoláveis e passíveis de uma descrição pormenorizada (Turner, [1974] 2008: 27-28).

Dawsey (2005 e 2009) observa que a suposição de Turner é a de que os ritos de passagem, assim como os dramas sociais, evocam uma forma estética que se encontra na tragédia grega, especificamente em sua versão aristotélica. Essa referência fica clara no olhar retrospectivo que o próprio Turner lança à sua obra, em 1974, em que observa como, em contextos culturais tão díspares, constrangimentos morais, externos ao indivíduo, subjugam ou limitam suas escolhas:

[...] embora no drama social sejam tomadas decisões de meios e fins e afiliação social, a ênfase - tanto quanto o interesse - recaem predominantemente sobre a lealdade e a obrigação, e, dessa forma, o curso dos eventos pode adquirir uma qualidade trágica. Conforme escrevi no meu livro Schism and Continuity (1957), no qual comecei a examinar o drama social, "a situação em uma aldeia Ndembu é muito semelhante àquela encontrada no drama grego, testemunhamos o desamparo do indivíduo humano diante dos Fados; mas, neste caso [e também no caso islandês como descobri] os Fados são a necessidade do processo social" (Turner, [1974] 2008: 30).

Turner define drama social como unidades de processo desarmônico que surgem em situações de conflito, possuindo, tipicamente, quatro fases observáveis de ação pública (2008). Em outro texto, o drama social é caracterizado pelo autor como o movimento de uma comunidade no tempo, que adquire uma forma dramática que se expressa pelo seguinte encadeamento: ruptura, crise e intensificação da crise, ação reparadora e desfecho (harmonia ou cisão social) ([1986] 2005).

O primeiro momento do modelo de drama social corresponde à ocorrência de ruptura de relações sociais entre pessoas ou grupos do mesmo sistema de relações ou de qualquer campo de interação social durável. Após a fase de ruptura, seguem, de maneira crescente, os conflitos entre indivíduos, setores e facções, revelando embates ocultos. No intuito de circunscrever o alcance da crise, uma ação pública reparadora é consensualmente empreendida por líderes, guardiões ou membros mais velhos do grupo social. O resultado ou desfecho do drama social pode se manifestar seja como a restauração da paz e da normalidade entre os 
participantes, seja como o reconhecimento social de uma ruptura ou cisão irremediável (Turner, [1986] 2005: 182).

A pesquisa de campo em outros contextos etnográficos convenceu Turner de que dramas sociais poderiam ser isolados para estudo em sociedades de diversos tamanhos e complexidades (Turner, [1974] 2008: 29).

Ao serem interpretados a partir do modelo de drama social formulado por Turner, os episódios descritos ao longo desse capítulo envolvendo os imigrantes japoneses e seus descendentes podem ser apresentados da seguinte maneira:

\section{Ruptura}

Nas relações dos imigrantes com o Japão: proibição dos jornais dos imigrantes em japonês com notícias sobre aquele país; proibição de material didático em japonês para as escolas dos filhos dos imigrantes; proibição da circulação de livros e revistas daquele país; proibição da exibição de filmes japoneses; fechamento do consulado-geral e da embaixada japoneses.

Nas relações dos imigrantes com a sociedade brasileira: proibição dos jornais em japonês com notícias de jornais brasileiros que então não chegavam ao interior; sentimentos antijaponeses disseminados pela Campanha Anti-Nipônica (década de 1930), pela campanha da nacionalidade ou da brasilidade promovida pelo Estado Novo e presente nos discursos, artigos e notícias veiculadas durante a guerra; privação dos direitos civis dos japoneses e nikkeis, considerados inimigos da pátria, espiões ou quintas-colunas;

Nas relações internas dos imigrantes japoneses e dos nikkeis: fechamento das escolas em língua japonesa, dos clubes (kaikan) e das associações culturais locais; proibição de reuniões, incluindo festas e comemorações dos imigrantes e nikkeis; proibição da fala do idioma estrangeiro sob pena de prisão; desocupação da principal região de concentração dos japoneses e nikkeis na cidade de São Paulo, a rua Conde de Sarzedas e arredores.

\section{Crise e intensificação da crise}

Surgimento das sociedades secretas leais ao imperador; destruição de plantações e propriedades de imigrantes que cultivavam hortelã e criavam bicho-da-seda; derrota do Japão na guerra, que acarretou a desestruturação de dois valores centrais dos imigrantes: a infalibilidade do imperador e a invencibilidade do Japão; conflito opondo os kachigumi e os makegumi: divisão no interior das colônias japonesas; Shindo Renmei: assassinatos, atentados e ameaças de morte no estado de São Paulo; atividade de oportunistas.

\section{Ação reparadora}

Arrecadação de donativos para as vítimas japonesas da guerra; questionamento público dos Peixes Voadores à tese dos vitoristas; campanha difamatória da Shindo Renmei e a sua marginalização junto aos japoneses e nikkeis; visita do grão-mestre da Higashi Honganji; participação dos japoneses e descendentes nas comemorações do IV Centenário; retomada das sessões de cinema japonês na capital e nas cidades do interior paulista.

\section{Desfecho}

Reconciliação entre os partidários dos grupos oponentes; re-agregação dos imigrantes japoneses e dos nikkeis em torno da Liberdade: por meio de instituições de cultura e lazer como as salas de cinema do bairro, a Sociedade Brasileira de Cultura Japonesa e a Aliança Cultural Brasil-Japão; desenvolvimento do comércio japonês no bairro; a crescente apreciação do cinema japonês por parte dos brasileiros. 
Em artigo publicado em 1970, Kumasaka e Saito analisam o significado das ações da das organizações que exigiam de seus membros lealdade absoluta e obediência cega: “A Shindo Renmei simbolizava o momento crucial na história dos imigrantes japoneses, na medida em que ela representava um esforço consciente para que a cultura japonesa fosse aceita no Brasil e não propriamente no sentido de persuadir seus compatriotas para o repatriamento" (Kumasaka; Saito, [1970] 1973: 454). As práticas, exigências e valores cultivados pela Shindo Renmei a impediram de alcançar esse objetivo na época. No pósguerra, a exibição de filmes japoneses no estado de São Paulo foi uma das maneiras pelas quais a cultura japonesa passou a ser, não apenas aceita, como também admirada no Brasil:

Foi também a década [passagem 1950-1960] em que a colônia experimentou um profundo sentimento de orgulho: os filmes começaram a atravessar as fronteiras do bairro e a atingir o público ocidental. [...] É como se, embutida na apreciação da crítica e do público brasileiros, estivesse presente uma aceitação, digamos, da nacionalidade japonesa por parte dos brasileiros (Futemma, 1986: 79).

\subsubsection{Hábitos de cinema}

Segundo Paulo Ramos (2008), os estudos de recepção cinematográfica têm como objetivo investigar, entre outros aspectos, de que maneira as críticas publicadas em jornais e revistas, os anúncios veiculados nos meios de comunicação e os cartazes afixados nas fachadas dos cinemas influenciam o diálogo do público com a obra (Ramos, 2008: 14). Seu estudo sobre as reminiscências de idosos acerca dos filmes inclui a investigação dos espaços cinematográficos da cidade freqüentados por seus entrevistados e o que denomina por "caminhos de cinema": os trajetos das casas às salas de exibição, o meio de locomoção usado e os lugares da cidade relacionados aos cinemas.

Como os freqüentadores japoneses e nikkeis das salas da Liberdade escolhiam os filmes que assistiam? De que maneira eles iam aos cinemas? Iam sozinhos ou acompanhados? Para Eunice Yokota ir aos cinemas da Liberdade era um programa familiar que ocorria sempre nas tardes de sábado, antes da luta livre transmitida na televisão. Os filmes eram escolhidos pelo pai, com base na leitura de resenhas em jornais japoneses. No relato de Eunice, nota-se uma forte demarcação de gênero - a autoridade paterna na escolha do filme, os gêneros de filme apreciados pelos homens e o interesse diferenciado da mãe:

O meu pai é quem escolhia o filme. Não tinha essa coisa de "Ah, eu quero ver aquele outro", "Bom, então você não vai". Porque o meu pai dirigia, ele tinha carro e a gente morava longe, na zona Leste. Então, era fácil ir porque a gente ia de carro. Então, no final 
não tinha nada para fazer: "Vou junto, né?" [risos]. [...] A minha mãe, ela gostava de determinados artistas, não era tanto da história do filme. Meu pai lia no jornal, porque no jornal vinha um resumo do que era o filme e, lógico, ele gostava de filme de samurai e de bandido, desse tipo de coisa que homem gosta. Então, no final ia pelo gosto do meu pai, porque ele era autoridade (risos) [...] A gente ia todo sábado à tarde. Eu lembro que era assim: a gente ia numa sessão que terminava lá pelas seis horas. Então, a gente devia ir lá pelas quatro, porque ainda era claro quando a gente saia do cinema. Aí voltávamos para casa e o meu pai gostava de ver luta livre na televisão, então íamos ao cinema mais cedo pra ele poder pegar a luta livre dele na televisão.

Como visto no primeiro capítulo, aos 8 anos de idade Jo Takahashi ia sozinho aos cinemas da Liberdade pesquisar filmes japoneses que seriam exibidos em seu bairro, São Judas Tadeu. Para arrecadar fundos, as sessões de cinema eram promovidas regularmente pela escola japonesa que ele freqüentava. Ele conta que inicialmente a escolha era feita "no papel", sem assistir aos filmes, deduzindo o filme pelo título e seus atores, pois não tinha acesso às criticas publicadas nos jornais japoneses. Isso o motivou a freqüentar os cinemas da Liberdade, construindo um conhecimento empírico para a programação de filmes japoneses que o auxilia até hoje, como diretor cultural da Fundação Japão:

Na época era muito tranqüilo. De São Judas até o bairro da Liberdade, eu ia de bonde ou de ônibus. Mas bonde era divertido porque era tudo aberto. Acho que demorava mais, mas era uma saída, um passeio, que era uma investigação também. Então tinha essa coloração de pesquisa: eu estou indo para o cinema porque estou fazendo pesquisa, porque eu vou escolher os filmes para passar naquelas sessões de bairro. [...] Eu ia sozinho. Ia, voltava para casa, contava o filme inteirinho para a minha mãe, e ela achava bacana: "Então vamos escolher esse filme e vamos falar para o sensei" [risos].

Takahashi indica também a importância, em outro momento de sua vida, das críticas cinematográficas de Rubem Biáfora, publicadas pelo jornal O Estado de S. Paulo na coluna Indicações da semana, para o conhecimento e a escolha dos filmes japoneses a serem assistidos:

No início, era só a imagem que aparecia no jornal ou o anúncio do filme, geralmente eram tijolos. Mas depois eu descobri as críticas de $O$ Estado de S. Paulo. Quem escrevia era o Rubem Biáfora. Ele também era um grande apreciador do cinema japonês, então eu sentia que as críticas dele com relação ao cinema japonês eram muito sólidas, muito pesquisadas.

O interesse de Ricardo Gonçalves pela cultura japonesa fez com que ele circulasse pela Liberdade, tomando contato com os filmes exibidos no bairro pelos cartazes afixados nas fachadas dos cinemas. O convívio de Gonçalves com os colegas nikkeis, não apenas na escola como freqüentando suas casas, fez com que ele se informasse sobre os filmes japoneses nas conversas dessas famílias: "Como eu passeava sempre nas ruas do bairro, era basicamente o 
contato pessoal com os cartazes, a propaganda na porta dos cinemas e as conversas também com os amigos e familiares dos amigos".

Marina Narahara descreve o momento em que passa a escolher os filmes assistidos no cinema. Nessa época, ela ia ao cinema com a avó e com os amigos da vizinhança, todos filhos de famílias japonesas. Ela se lembra do trajeto do ônibus que ia da Santa Cecília à Liberdade, e do gosto exclusivo de sua turma pelas expressões artísticas japonesas:

Depois eu que comecei a escolher, eu ia, via o filme da Hibari, gostava e ia de novo. Eu ia sempre com amiguinhas, vizinhas, minha avó, aí já era o contrário, eu pedia para a minha avó ir comigo. Eu pegava ônibus, era o circular Avenida, que eu pegava na Santa Cecília, e ficava circulando: descia a Angélica, ia até a rua das Palmeiras, onde eu morava, passava pela [praça da] República e ia até a avenida Liberdade. [E vocês só iam às sessões de dia ou nas sessões da noite?] Eu ia mais na sessão de dia. [...] Eu andava mais com o pessoal da colônia, porque na minha vizinhança tinha algumas famílias japonesas, e essa era a minha turma. E a gente só ia ver filmes japoneses, só ouvia música japonesa.

\subsubsection{Público japonês: reencontro e atualização}

Para a maior parte dos filhos dos imigrantes japoneses que concederam depoimentos para esta pesquisa, ir aos cinemas da Liberdade era um programa familiar que incluía, eventualmente, alguns vizinhos e amigos nikkeis, como indicam as memórias de infância presentes nos relatos. ${ }^{61}$ Parece haver, no entanto, uma diferença geracional de significados atribuídos à experiência de freqüentar os cinemas da Liberdade, entre os imigrantes japoneses e seus filhos.

Para Sussumu Tanaka, irmão do fundador do Cine Niterói cuja trajetória foi descrita no primeiro capítulo, assistir aos filmes japoneses significava "matar a saudade do Japão". Numa fala transcrita no segundo capítulo, Jean Claude Bernardet observa, a partir de sua experiência pessoal, a especificidade da relação dos imigrantes com certos filmes de seus países de origem, em que eles "se encontravam" nos costumes familiares apresentados. O reencontro simbólico do imigrante com seu país de origem por meio do cinema é uma idéia presente na fala de Ricardo Gonçalves: "Para o imigrante o filme japonês é um reencontro com a sua pátria irremediavelmente perdida, pelo menos naquele momento, que não era fácil como hoje fazer viagens ao Japão. Era dificílimo”. Isso parece corresponder ao comentário Olga Futemma acerca da relação da geração dos pais dela com o cinema japonês:

\footnotetext{
${ }^{61}$ Isso é indicado nos depoimentos de Olga Futemma, Marina Narahara, Eunice Yokota. Para Teresinha e Clara Nakayama ir ao cinema japonês também era um programa familiar, embora elas já tivessem 14 e dez anos, respectivamente, na época da mudança da família para o bairro Liberdade, onde residiram por quinze anos.
} 
Tem uma coisa muito profunda que é ouvir a sua língua de origem, não numa conversa, mas em caixas acústicas [...] imagina o que é você ficar muito tempo num lugar em que se fala uma língua completamente diferente. [...] Teu jeito, tua gíria, é um reencontro consigo mesmo, eu acho que o cinema muitas vezes permite isso.

Perguntada sobre a relação de seus pais com os filme japoneses, Eunice Yokota argumenta que os filmes funcionavam para eles como uma fonte de informação e de atualização sobre o Japão. Ela se lembra, inclusive, da exibição de cinejornais japoneses, "os últimos a dar as primeiras", mas que contariam com a força das imagens. As transformações ocorridas no Japão no período do pós-guerra eram acompanhadas pelos pais de Eunice através dos filmes exibidos em São Paulo, suscitando um sentimento de desilusão para com o país de origem:

Meus pais eram crianças quando vieram ao Brasil, então eu acho que pouca coisa deve ter ficado do Japão antes dos cinco anos. Então para eles o cinema também era uma fonte de informação, quer dizer, eles viam os filmes e falavam: - Ah, está desse jeito, né? Quer dizer, eles achavam que as pessoas também estavam mudando, que o país estava mudando. Em 1965 eles foram para o Japão, e chegaram à conclusão que todo o [imigrante] japonês chega, que é muito bonito, mas eu não quero voltar a morar lá.

A atualização da imagem do Japão por meio dos filmes e o decorrente sentimento de desilusão com as mudanças ocorridas naquele país também estão presentes na lembrança de Olga Futemma sobre a relação de seus pais com o cinema. Nos relatos de Olga, assim como nos de Eunice, o sentimento de desilusão com o Japão do pós-guerra funcionou como uma reafirmação da decisão dos pais dela de fixarem residência no Brasil: "Tem a questão da atualização, de como é que está lá. E muitas vezes eu lembro do meu pai falando: Ah, mas a juventude lá... Uma certa preocupação e também uma questão de reafirmar a própria opção de ser um imigrante, de ter saído de lá”.

Ricardo Gonçalves lembra-se também de um sentimento semelhante provocado por alguns filmes na geração dos imigrantes. No entanto, diferente das outras falas, transparece aqui um certo saudosismo ou tradicionalismo: "É, uma forma de atualização e também de uma certa forma uma desilusão: Ah, o Japão não é mais aquele Japão em que eu vivi minha infância, é um país degenerado moralmente, é um país americanizado, e vai por aí afora”.

Olga Futemma cita o filme Bom dia (Ohayo, 1959) de Yasujiro Ozu, para demonstrar como os processos de transformação social, exemplificados pela chegada da televisão, ocorreram de maneira paralela no Brasil e no Japão. Ela comenta que atualmente sua mãe acompanha as transformações do mundo pela televisão: 
O imigrante não está lá naquele dia-a-dia que está mudando, mas ele está num dia-a-dia aqui que também está mudando. Então se você ver um filme como Bom dia de Ozu, dos dois meninos e toda a questão da televisão: "Ai, eu quero a televisão", como um ícone da penetração americana naquela sociedade, um pouco depois, estávamos nós aqui: "A gente quer uma televisão!". De certa forma, a mudança se deu muito no paralelo. [...] Então eu não acredito que haja um choque. Acho que pode haver um estranhamento, perderam-se alguns valores. Minha mãe tem 86 anos e hoje ela assiste a televisão. Ela está imersa neste mundo da tv brasileira, ela acompanha novela. Quer dizer, hoje para ela ver um filme violento ou de yakuza, qual é a diferença? Então ela está imersa nesse mesmo mundo, que passou pelas mesmas grandes mudanças.

Jo Takahashi rememora da chegada da televisão em sua casa e, junto com ela, do National Kid, o primeiro herói exibido na televisão brasileira e uma importante referência de sua geração: "O meu imaginário era pontuado por National Kid e filmes de ninja e samurai do Cine Niterói. Essa era a minha infância”. Antes disso, ele assistia à televisão na casa dos vizinhos. Seriados como Lassie, Rin-Tin-Tin, Roy Rogers, Tarzã e Jim das selvas eram assistidos na casa dos vizinhos espanhóis, que tinham um filho da mesma idade. "A outra família, italiana, era uma família sem crianças e eram velhinhos. Então eles me chamavam para assistir comédias, a Praça da alegria, eu não gostava muito". Takahashi comenta sobre o dia da chegada da televisão, uma cena que remete ao filme de Ozu:

Um certo dia, o meu pai resolveu comprar uma televisão. Aí eu fiquei esperando e falei para o meu vizinho: "acho que eu não vou mais, porque vai chegar a televisão em casa". Aí ele ficou muito chateado. [...] O dia em que veio a televisão, os dois vizinhos ficaram olhando pelo muro, tristes, e eu alegre, feliz da vida, queria ver logo. [Parece aquele filme do Ozu, Ohayo.] Exatamente! É muito parecido. Ohayo eu vi quando eu tinha uns 40 anos, pela primeira vez, aí eu me lembrei muito desse detalhe.

Ricardo Gonçalves se lembra de ter traduzido alguns filmes da série National Kid, que iniciou sua carreira no cinema, antes de ser exibida internacionalmente na televisão. Para ele, o sucesso alcançado por essas séries nas salas de cinema significou o início da decadência do cinema japonês. O relato de Gonçalves demarca uma diferença de geração em relação às referências de Takahashi. Mas a menção ao gosto dos netos por Naruto revela uma linha de continuidade desses gêneros de programa japonês na televisão brasileira:

No fim da década de 1960, apareceu o famigerado Godzilla, que teve uma série de continuadores. E vieram as séries para a televisão. Lembra-se do National Kid? Eu traduzi uns filmes do National Kid. Eu achava divertidíssimos, tremendamente ingênuo, né? National Kid contra os Incas Venusianos. Incas Venusianos era uma coisa... Isso é space opera de última qualidade. E essas coisas acabaram pegando e assassinaram o bom cinema japonês [risos]. Teve uma geração que cresceu assistindo estas coisas. Agora eu sou da geração anterior, e quando apareceu isso, eu achei abominável: "Não, isso aqui é a decadência, é o fim". E hoje estamos no mundo dos animês. Os meus netos falam tanto de um tal de Naruto! 


\title{
3.1.7. Língua japonesa: diversidade e aprendizagem
}

Para alguns dos freqüentadores dos cinemas da Liberdade, o contato freqüente com os filmes japoneses propiciou uma ampliação de seus conhecimentos sobre a língua japonesa ${ }^{62}$. A leitura dos mangás e a audição dos filmes japoneses aprimoraram o estudo de Jo Takahashi do japonês, iniciado na São Judas Gakuen, escola japonesa que ele freqüentou durante a infância. Há algo no cinema, no entanto, que o distingue das outras formas de aprendizagem do idioma: a abertura para outros mundos para além do cotidiano, aspecto que propiciou a Takahashi o contato com uma diversidade lingüística até então desconhecida. O contraste entre o japonês antigo falado filmes de samurai da Toei e a linguagem cotidiana empregada nos filmes de samurais atuais, as diferenças entre as linguagens dos samurais, nobres e camponeses, além das diferenças entre o japonês ouvido nos filmes contemporâneos e o falado por seus pais são alguns aspectos da língua comentados por Takahashi:

\begin{abstract}
Algum benefício que eu tive do cinema japonês talvez seja a língua. Acabei aprimorando o meu japonês através do mangá, que eu lia, e através do cinema, que eu ouvia. [...] O fato é que o cinema mostra um mundo que não é o cotidiano, são outros mundos. Então o que eu aprendi com o cinema japonês é que existem maneiras de falar diferentes, nos filmes de samurai, por exemplo, a linguagem que se falava era uma linguagem da época. Os filmes de samurai de hoje, eles estão falando a linguagem cotidiana, você viu o filme A honra do samurai (Bushi no Ichibun, 2006)? Ele fala uma linguagem de hoje. Mas na época da Toei, de antigamente, eles conservavam a maneira antiga de se falar. [E havia palavras que você desconhecia?] Desconhecia e acabei descobrindo pelo cinema. E existe uma linguagem dos nobres, existe a linguagem dos samurais e existe a linguagem dos camponeses, eram totalmente diferentes, apesar de ser tudo japonês, mas é absolutamente diferente. Existe uma maneira de falar do yakuza e existem as gírias também. O que eu via era que o japonês que era falado no cinema, nos filmes mais contemporâneos, era bem diferente do japonês que meus pais falavam em casa.
\end{abstract}

Como visto, Ricardo Gonçalves aprendeu japonês através dos mangás e com a ajuda dos colegas nikkeis da escola. A necessidade de tradução dos filmes de época [jidaigeki], em que se falava o japonês clássico ou antigo, levou Gonçalves a estudar o japonês literário. Em sua trajetória, o contato com diversas expressões artísticas e culturais japonesas, como o mangá, os filmes de época e o teatro nô, promoveu seu aperfeiçoamento na língua japonesa, empregado atualmente para a tradução de textos budistas clássicos:

\footnotetext{
${ }^{62}$ Além de Jo Takahashi e Ricardo Gonçalves, as irmãs Clara e Teresinha Nakayama citam também esse papel desempenhado pelo cinema japonês como possibilidade de aperfeiçoamento da língua.
} 
Nós temos o japonês moderno, o japonês falado hoje, e temos o japonês clássico. Então muitos filmes de época eram falados em japonês clássico. Isso me obrigou a estudar o japonês literário, o que já estava nos meus planos. Eu gostava de cultura clássica e o Japão contemporâneo era secundário para mim. Quando eu comecei a ler mais ou menos em japonês, a minha primeira preocupação foi estudar gramática clássica. Isso já era no terceiro colegial, nas vésperas do vestibular, que eu comecei a trabalhar no grupo de teatro de $n \hat{o}$, e teatro nô é em língua clássica, em japonês do século XV. O teatro nô são textos do século $\mathrm{XV}$, então tive que aprender aquele japonês literário, rebuscado, que servia também para traduzir os filmes de samurai, os filmes de época. [Porque era um repertório que o mangá não te dava.] Não, o mangá era todo falado em japonês contemporâneo. Agora o teatro clássico logicamente era na língua literária. Isso veio depois, e foi importante para mim para o budismo: os textos budistas são textos clássicos escritos em japonês literário.

Gonçalves observa também algumas diferenças lingüísticas regionais apresentadas nos filmes japoneses, especialmente nas comédias. Segundo ele, a comédia japonesa é a arte da palavra: sua comicidade se expressaria não tanto através de gestos, mas por meio de palavras, frases e trocadilhos engraçados. Assim como os filmes de época, traduzir essas comédias constituiu para ele outro desafio, que o levou a aperfeiçoar seu conhecimento da língua:

E uma outra diferença que é muito importante: os dialetos locais. Uma comédia passada em Osaka, digamos, é toda no dialeto de Osaka, que não tem nada a ver com a língua falada em Tóquio. Um filme literário passado em Kyoto, antiga capital, é falado na linguagem de Kyoto, que também é completamente diferente. Por exemplo, Kyoto eu conheço bem porque eu vivi lá. Kyoto é a Roma do Oriente: a cidade dos templos, dos museus e dos palácios. Em Kyoto não se diz: "Domo arigatô gosaimashita", se diz: "Ookini". Ookini é obrigado em Kyoto. Vendedora de flores nas ruas de Kyoto diz: "Ohana irimahen ka, ohana dodosu? Ohana ikaka desuka? Ohana iranai desuka? - Ohana irimahen ka, ohana dodosu”, parece uma outra língua. Para nós seria como alguém falar espanhol, italiano, ao invés do português. E tem algumas comédias que jogavam com isso, que faziam, por exemplo, um personagem da região de Osaka fazer uma espécie de duelo verbal com alguém da região de Tóquio, cada um falando com o seu dialeto local, então surgia uma série de coisas engraçadas aí.

Marina Narahara trabalha como tradutora do japonês para o português. Assim como Jo Takahashi e Ricardo Gonçalves, ela aprendeu japonês por meio dos mangás que seu pai comprava regularmente e que ela lia desde os cinco anos de idade, na mesma época em que começou a freqüentar os cinemas da Liberdade com sua avó. Aos 6 anos, ela estudou por um ano numa escola japonesa localizada no parque Dom Pedro. Aos 17 anos, freqüentou o curso de japonês do Bunkyo, onde conheceu a turma do grêmio. O contato intenso de Marina com os mangás, revistas, filmes e músicas japonesas foi determinante em sua trajetória: cultivando desde a adolescência o sonho de conhecer o Japão, formou-se em letras e, aos 23 anos, viajou ao país como bolsista da província de Oita. Apesar de estudar o japonês no Brasil, em sua segunda ida ao Japão, ela percebeu a distância entre o seu conhecimento do idioma e as exigências profissionais de uma empresa japonesa: 
Da segunda vez que eu fui ao Japão, eu trabalhei lá, era outra situação. Eu fiquei quatro anos trabalhando lá numa firma, e aí é que eu comecei a aprender o japonês mesmo, porque enquanto estudante, a gente não tem aquela cobrança. Entrando numa firma é que a linguagem e o comportamento [adequados] são exigidos. Você não pode chegar no telefone e falar de qualquer jeito. Então para mim era muito difícil, foi um choque, pela primeira vez eu falei: "Nossa, eu não conheço nada do japonês e do Japão! Eu não sei me comportar como um japonês trabalhando numa firma".

\subsubsection{Público nikkei: uma educação sentimental}

Se, para Ricardo Gonçalves a relação que os imigrantes estabelecem com os filmes japoneses é de reencontro, para os nisseis tratava-se de um encontro com um país desconhecido, configurando uma relação de aprendizagem por um dos únicos meios disponíveis na época: "É o cinema como meio de transmissão cultural e como canal de informação numa época em que a tecnologia da informação ainda estava engatinhando. Sobre isso, eu não posso deixar de mencionar as redes de exibição dos filmes”.

Apesar de estudarem no curso de ciências sociais da Faculdade de Filosofia da Universidade de São Paulo na mesma época, Eunice Yokota e Sedi Hirano não se encontravam: "De vez em quando tinha aquelas assembléias e ele vinha. Ele era mais velho do que a gente e estudava a noite. Ele já era uma pessoa que trabalhava e que fazia o curso à noite, não era como nós, filhinhas de mamãe, né?”. Com a perda do pai aos 13 anos de idade, Sedi Hirano passa a trabalhar para custear seus estudos. Ele estabelece uma correspondência entre certos valores apreendidos no convívio familiar, como a ética do trabalho, frases de Confúcio e valores reconhecidos em alguns filmes japoneses:

O que me fascina em certos filmes japoneses é a mensagem: mesmo que tenha essa questão do samurai, existe o código de honra, que é a regra. Confúcio fala do ritual: o homem tem que seguir o ritual. Então, para ser um bom samurai ele tem que seguir o caminho do bom samurai. O ritual que de uma forma ou de outra é iluminado por uma religião, pelo budismo ou por alguma coisa. E por certos valores. E aí eu percebo a minha mãe, em épocas mais críticas, épocas mais difíceis da vida na família, ela mais trabalhava. Quanto mais dificuldade tinha, mais trabalhava. Ela não ficava retirada no quarto chorando. Depois, na hora de descansar, pode ate ter chorado, mas antes, tudo que tinha que fazer ela fazia.

Clara Nakayama comenta o significado da experiência de assistir aos filmes japoneses nos cinemas da Liberdade no período em que a família residiu no bairro, de 1950 a 1965 . A aprendizagem de aspectos da vida contemporânea do Japão, bem como de episódios da história do país é enfatizada em seu depoimento. Mesmo morando em núcleos de concentração de japoneses, como Registro e Mirandópolis, ela menciona uma carência de informações sobre 
o Japão: se no meio rural as informações eram escassas, ao se mudar de Registro para a colônia Aliança durante a guerra, a família de Clara também sofreu com as restrições de informações a que estavam sujeitos os imigrantes japoneses e seus descendentes na época:

Eu acho que foi bastante importante, porque a gente nasceu no interior, numa família interiorana mesmo, então a gente não tinha contato com o que passava no Japão, com as histórias que aconteciam no Japão. Através do cinema, a gente aprendeu muita coisa. Mesmo as histórias antigas de samurai, a gente não conhecia também. Nossos pais não contavam muitas histórias. Então são coisas que a gente aprendeu muito.

Essa carência de informações sobre o Japão é citada também por Eunice Yokota, que, ao contrário de Clara Nakayama, morava na capital, no bairro da Mooca, isto é, sem o convívio freqüente com outras famílias japonesas: "Porque como meus pais vieram crianças, eles não eram de ficar contando como era o Japão. Eles se alfabetizaram aqui, falavam português e a gente morou por muito tempo no meio de não-japoneses, então eles eram muito integrados". Para Eunice, havia "um vácuo" de informações sobre o Japão que o cinema preencheu, gerando uma interpretação satisfatória sobre determinados comportamentos familiares. A lembrança que Eunice guarda dos filmes japoneses é marcada pelo patriarcalismo tradicional, manifesto nas relações de gênero. Há uma correspondência entre os comportamentos representados pelo cinema e aqueles observados na própria família, além da demarcação de uma diferença de gerações:

A sensação mais forte que eu tenho desses filmes é a posição do homem. Os homens eram todos poderosos e, as mulheres, muito submissas. Aquilo era uma coisa que me agredia, porque todo o relacionamento que você via nos filmes - amoroso, de amizade, de pai e filho - era tudo nessa base. O que predominava era o fato de que eu mando e você faz. Aquilo me agredia muito e se repetia em todos os filmes, porque era a filosofia deles. Agora, nos filmes do Ozu não existia isso, era um clima em que o pai aceitava o que as filhas falavam, aceitava a mudança da vida depois da guerra. Para mim, aquilo parecia uma mudança. $\mathrm{Na}$ minha família, eu sou a única mulher. Tenho dois irmãos, muitos primos e quase não tenho prima. Os irmãos do meu pai são todos homens, tinha uma irmã, que faleceu logo. Então, era uma família extremamente masculina e eu tinha essa revolta: "Mas ninguém faz nada!". Porque eu tinha um irmão mais velho e um mais novo, e ninguém fazia coisa nenhuma dentro de casa. Aí eu entrava de férias, tinha que ajudar a minha mãe e me revoltava com aquilo: "Mas como? Vocês não fazem nada? Só eu que tenho que ajudar?". Era uma coisa que naquela época era muito comum, era aceito e eu via isso nos filmes. E era a parte que eu não gostava, porque isso estava no mesmo clima que eu tinha em casa, que era uma coisa que eu não aceitava. Eu falei: "Ah, isso aí veio do Japão!" [risos]. Então, o cinema foi uma forma de conhecer como era a cultura dos seus pais. [...] O cinema cobriu esse vácuo, você olhava como as coisas aconteciam: "Ah, então é isso, acontece aqui na minha casa porque existe esse traço da cultura que eu não sabia, pensava que era do meu pai e da minha mãe". 
Olga Futemma fala sobre as múltiplas referências em seu processo de formação okinawana, japonesa e brasileira - ressaltando, a princípio, o caráter harmonioso desta justaposição, devido ao entendimento do valor da arte, um valor herdado de uma família de atores e musicistas okinawanos: "Ao mesmo tempo em que parece que eu nasci no mercado, parece que eu nasci no meio de um ensaio, de teatro e música". Ela se refere ao avô materno, liderança da comunidade okinawana em São Paulo e também professor de canto clássico: "Ele tocava shamisen, ele cantava, e os senhores do mercado todo final de semana chegavam na casa dele, todos com suas malinhas de shamisen, passavam a tarde conversando, cantando". O grupo chegou a se apresentar no teatro Colombo, na zona Leste, no Arthur Azevedo e até no Teatro Municipal. "E eu era a menina na coxia, ficava ali olhando os telões subindo e descendo, aquele nervoso, o frisson, eu estava no star system dos okinawanos, as fofocas, uma vida, uma pulsação muito interessante", rememora a cineasta.

Em relação a sua formação como espectadora de cinema e como cineasta e pesquisadora, ela aponta uma aprendizagem no discernimento de valores artísticos e na formação de um olhar crítico:

A gente ia assistir cada coisa! [risos] Mas a gente se divertia e começava a ter um certo olho esperto, de comparação. O que era um filme bom, o que não era um filme bom. O que era um filme só para passar o tempo e o que era uma obra de arte. Eu acho que comecei a ter ali, muito com ajuda de meu pai, um certo olhar crítico para discernir qualidades.

A atuação dos filmes japoneses nos espectadores nisseis, como sugerida nos depoimentos de Gonçalves, Hirano, Nakayama, Yokota e Futemma, talvez possa ser comparada à atuação social da briga de galos para os balineses, conforme observada por Clifford Geertz (1989) em sua pesquisa de campo. Por intermédio de ambos - brigas de galo em Bali e filmes japoneses em São Paulo - ocorreria uma espécie de educação sentimental, na qual a emoção é mobilizada para fins cognitivos:

O que a briga de galos diz, ela o faz num vocabulário do sentimento - a excitação do risco, o desespero da derrota, o prazer do triunfo. Entretanto ela diz [...] que é com essas emoções, assim exemplificadas, que a sociedade é constituída e que os indivíduos são reunidos. Assistir a brigas de galo e delas participar é, para o balinês, uma espécie de educação sentimental. Lá, o que ele aprende, é qual a aparência que têm o ethos de sua cultura e sua sensibilidade privada [...] quando soletradas externamente, num texto coletivo (Geertz, 1989: 317). [...] as formas de arte originam e regeneram a própria subjetividade que elas se propõem a exibir. Quartetos, naturezas mortas e brigas de galos não são meros reflexos de uma sensibilidade preexistente e representada analogicamente; eles são agentes positivos na criação e manutenção de tal sensibilidade (Idem, ibidem: 319). 
A proposição de Geertz em abordar as forças culturais como textos ou "obras imaginativas construídas a partir de materiais sociais" implica na interpretação das formas simbólicas em termos de seu funcionamento, em situações concretas, para organizar as percepções - significados, emoções, conceitos e atitudes (Geertz, 1989, 317). Há nisso uma dupla implicação: por um lado, esses textos refletem sensibilidades pré-existentes, tornado assim possível, ao balinês, descobrir o temperamento de sua sociedade numa briga de galos, e quem sabe, ao nikkei de São Paulo (e também ao não-nikkei), aprender aspectos da sociedade e da cultura japonesas através dos filmes. Por outro lado, esses "textos" organizam as percepções de seus "leitores", ou seja, na briga de galos, o balinês forma o seu temperamento ao mesmo tempo em que descobre o temperamento de sua sociedade. Para exemplificar esse processo, Geertz cita um comentário de Northorp Frye a respeito da Poética de Aristóteles:

\footnotetext{
Nossas impressões sobre a vida humana são colhidas uma a uma e permanecem, para a maioria de nós, frouxas e desorganizadas. Entretanto, encontramos freqüentemente na literatura coisas que subitamente coordenam e trazem a foco uma grande quantidade dessas impressões, em isso é parte daquilo que Aristóteles queria dizer com o acontecimento humano típico ou universal (Fry apud Geertz, 1989, 39).
}

Da mesma forma, a briga de galos focaliza experiências variadas da vida cotidiana, criando um "acontecimento humano paradigmático" equivalente ao acontecimento típico ou universal de Aristóteles. Teria ocorrido o mesmo com os filmes japoneses em São Paulo?

Para Sedi Hirano, os filmes japoneses teriam atuado para a organização de significados, emoções e conceitos de modo articulado à aprendizagem de valores na família e dos conceitos e teorias na vida escolar e universitária. Exemplo disso foi a equivalência estabelecida por ele entre o livro de Max Weber, A ética protestante e o espírito capitalista, e o filme A espada diabólica, de Tomu Uchida, num evento acadêmico. No início de 2008, ao ministrar a aula magna da Faculdade de Filosofia, Letras e Ciências Humanas da Universidade de São Paulo, cujo tema foi "Ética e capitalismo", Hirano estabeleceu um paralelo entre as consequiências da adoção da ética protestante e o processo de desumanização do protagonista de A espada diabólica, exatamente como descrito por ele no capítulo dois desta pesquisa.

A questão da aprendizagem por meios dos filmes parece se colocar de maneira mais enfática nos depoimentos de Clara Nakayama e Eunice Yokota, que, por circunstâncias diversas, apresentavam uma carência de informações e conhecimentos sobre o Japão que o cinema supriu. Clara e sua irmã Teresinha praticamente só assistiam aos filmes japoneses, constituindo assim a única referência de cinema delas. No caso da fala de Eunice, a organização das percepções ocorreu em relação a certas atitudes e emoções familiares 
“desorganizadas" ou pelo menos, percebidas e não compreendidas, que ela aprendeu a reconhecer e a significar com os filmes japoneses.

\subsection{O público não-nikkei: penetras numa festa de família}

\subsubsection{Brasileiros orientalizados}

Foi no interior dos cinemas japoneses, na Liberdade, que senti pela primeira vez, na pele, a força do preconceito de raça. Sentia-me diferente dos outros. Acendiam-se as luzes e, em toda a sala, só um era não-nipônico. O único. Provavelmente ninguém me notasse na sala comprida e cheia. Jamais me disseram uma palavra ou fizeram um gesto. A discrição, vizinha da sutileza, é marca japonesa. Mas um sentimento fundo, na epiderme, me tomava. Eu me notava. Provavelmente eu estivesse sobrando ali (João Antônio, 1986, 78).

Como visto no capítulo anterior, em meados dos anos 1950, o escritor João Antônio aproximou-se de expressões artísticas japonesas, como o cinema, a literatura, as artes plásticas e marciais, e passou a freqüentar o bairro da Liberdade, após assistir ao filme Rashomon (1950), de Akira Kurosawa. Antônio afirma ter freqüentado assiduamente o Cine Niterói e o Cine Tokyo nessa época. No fragmento destacado, ele associa o preconceito racial sentido nas salas da Liberdade com o fato de ser o único não-nipônico presente naquelas sessões.

Jo Takahashi interpreta o preconceito sentido por João Antônio como um processo pessoal interior, relacionado à percepção subjetiva da diferença. Ele discorda do fato de Antônio ser o único não-japonês naquelas sessões, chamando a atenção para o trabalho de pesquisa e documentação empreendido por José Fioroni Rodrigues, apreciador do cinema japonês desde a década de 1940:

É, certamente ele deve ter sentido isto. Mas, não sei, acho que o preconceito você nota no momento em que você se sente diferente mesmo, às vezes nem é um preconceito de fora para dentro, mas de dentro para fora, acho que isso é que o João Antônio deve ter sentido. Mas eu tenho certeza de que ele não era o único. Desde a década de 1940, um grande freqüentador era o José Fioroni Rodrigues. Ele assistiu a todos os filmes, sem exceção. Fioroni é um cinéfilo do cinema japonês impressionante, ele acabou aprendendo a falar o japonês através do cinema e colecionou todos os recortes de jornal de todos os filmes japoneses que passaram aqui. Acho uma pena que isso esteja recluso com ele, ele não quer abrir este material para ninguém, não quer compartilhar.

José Fioroni Rodrigues tomou contato com o cinema japonês em 1949, nas sessões realizadas no Cine São Francisco, na rua Riachuelo, atrás do Largo São Francisco. "Eu morava lá perto e todos os dias passava na frente. De tanto ver os cartazes, fiquei curioso e acabei entrando" (Moribe, 1991). Em relação à língua japonesa, ele iniciou seu aprendizado 
com um professor nativo e em 1959 ingressou na primeira turma do curso de japonês da Aliança Cultural Brasil-Japão, onde estudou até 1964 (Kobayashi, 2005: 42).

A Aliança Cultural Brasil-Japão foi fundada em 1956 como um órgão auxiliar da então Sociedade Paulista de Cultura Japonesa, o Bunkyo, com a finalidade de desenvolver atividades de intercâmbio cultural tendo como público os nisseis, sanseis e os brasileiros nãodescendentes em geral (Handa, 1987, 763). Essas atividades de intercâmbio cultural foram decisivas para o aumento do interesse de Carlos Reichenbach pelo cinema japonês. Ele descreve as sessões de filmes japoneses sem legendas realizadas nessa instituição, que eram precedidas por uma fala de José Fioroni Rodrigues que, tal como um katsuben ou benshi apresentando um filme estrangeiro no Japão, realizava uma contextualização histórica e resumia o enredo dos filmes para os espectadores:

Eu acho que o grande interesse pelo cinema japonês nasce exatamente porque a minha mãe tinha feito o curso de ikebana e, por estímulo dela, eu comecei a freqüentar a Aliança Brasil-Japão. Ela disse: "Está tendo sessões de cinema". Foi nesse momento que eu acho que o cinema japonês entrou de uma forma decisiva na minha vida. Foi especialmente uma projeção de Intendente Sansho sem legendas. Num certo sentido, esse filme para mim foi um divisor de águas. Porque uma coisa interessante do trabalho que a Aliança Brasil-Japão fazia, como as cópias dos filmes que vinham para cá em $16 \mathrm{~mm}$, vinham sem legenda, o que eles faziam? Faziam uma publicação, um panfleto, e quem fazia esses panfletos era um dos maiores especialistas do cinema japonês, de quem depois eu fiquei amigo, que é o José Fioroni Rodrigues. Antes de falar do filme, ele fazia uma análise histórica, falava do xogunato etc. Você tinha uma aula de história, antes de entrar propriamente no filme. Você acabava de ler o folheto e já sabia tudo o que ia ver, obviamente. Você conseguia aprender tudo. Eu comecei a gostar de ver filme sem legenda exatamente com as experiências da Aliança Brasil-Japão [...] Para mim foi fundamental. Acho que muita gente também começou a se informar, a se interessar por cinema japonês através deste tipo de divulgação. Eu acho que a Aliança Brasil-Japão foi como a Casa de Goethe para o cinema alemão, um órgão de difusão da cultura deles, mas que enxergavam o cinema como uma manifestação tão importante quanto a literatura ${ }^{63}$.

Ricardo Gonçalves descreve a existência, no início dos anos 1960, de uma pequena comunidade orientalizada, isto é, de não-nikkeis apaixonados pela cultura japonesa que comiam em restaurantes japoneses, assistiam aos filmes japoneses na Liberdade, namoravam garotas nisseis e, a partir de 1961, passaram a freqüentar o programa de meditações do templo zen da rua São Joaquim. Entre os membros dessa comunidade, ou fauna, Gonçalves cita, além dele mesmo e de José Fioroni Rodrigues, o crítico e pesquisador da Cinemateca Brasileira, Caio Scheiby:

\footnotetext{
${ }^{63}$ É possível que essas sessões de cinema japonês precedidas da contextualização histórica oferecida por José Fioroni Rodrigues tenham acontecido no final de 1967. Há uma referência de um texto de autoria de Rodrigues, intitulado "Breve História do Cinema Japonês I e II" nos Cadernos ACBJ [Aliança Cultural Brasil-Japão], publicados entre novembro e dezembro de 1967.
} 
Como eu atuei nesta área [tradução de filmes da Toho] durante muitos anos, entre 1960 e 1972, eu percebi que, pouco a pouco, formou-se um público que eu diria orientalizado, compreendendo não apenas nikkeis, mas brasileiros apaixonados pela cultura japonesa, e isso em todos os aspectos. Então os rapazes como eu, entre muitos, a gente assistia a filmes, comia em restaurante japonês, namorava garotas nisseis, e por aí afora [risos]. Na época eu era bastante orientalizado, hoje eu diria que eu me desorientalizei com o passar do tempo, naquele momento eu acho que $90 \%$ da minha vida girava em torno de japoneses e de cultura japonesa. E tinha várias pessoas assim, que depois, a partir de 1961 o templo zen lá da Rua São Joaquim lançou um programa de meditações, zazen, aberto para brasileiros, eu comecei a freqüentar também, e a mesma fauna das pessoas que iam ao cinema, iam aos restaurantes, faziam também zazen, então uma pequena comunidade orientalizada. [...] Algumas das pessoas ali eram críticos de cinema, alguns deles eu tinha um contato até mais estreito porque eles freqüentavam o escritório da Toho, tinha o Fioroni, tinha o Caio Scheiby e outros. Tinha um grupo de freqüentadores mais ou menos constante.

Ainda que não fizesse parte estritamente da mesma turma, a experiência do escritor João Antônio com a cultura japonesa e com os japoneses poderia, com base na definição de Gonçalves, ser qualificada também como orientalizada, colocando-o assim nessa mesma comunidade, embora um pouco antes, assim como o cineasta Carlos Reichenbach, embora um pouco depois:

\begin{abstract}
Eu comecei a freqüentar com muita assiduidade o cinema japonês com um grupo de amigos, pessoas com quem eu estudava, amigos próximos, entre eles um colega de São Luiz ${ }^{64}$, o Hideo Nakayama. Mas foi antes até, um colega de Santa Inês, que chamava Harunobu Kato. Um grande amigo daquela época, o hoje engenheiro e paisagista Rodolfo Ricardo Geisel, que foi inclusive aluno do Burle Marx. O Antônio Manuel dos Santos, que foi meu assistente depois, quando eu fui fazer meu primeiro longa, tinha mais umas duas ou três pessoas com quem a gente começou a freqüentar muito, não só com mais assiduidade os cinemas, como a freqüentarmos os templos. Especificamente o templo budista lá próximo à avenida Liberdade. Aí a convivência foi muito mais constante. Foi exatamente o momento em que eu só via filme japonês.
\end{abstract}

Assim como José Fioroni Rodrigues, Walter Hugo Khouri e Rubem Biáfora estabeleceram um primeiro contato com o cinema japonês no final da década de 1940, no Cine São Francisco. Em texto de 1997, Khouri refere-se a um grupo de brasileiros que freqüentavam essa sala, já aficionados pelo cinema japonês, consistindo de jornalistas, críticos, universitários e cinéfilos. "Lembro-me da forte emoção que me causaram Vida de artista, de Buntaro Futagawa, e o Crime da quinta, de Teinosuke Kinugasa, ainda no tempo das primeiras exibições, que davam uma amostra do cinema de excepcional qualidade formal e temática [...]". Como visto, Vida de artista foi o primeiro filmes japonês exibido nos pósguerra, em 1947.

\footnotetext{
${ }^{64}$ Escola Superior de Cinema São Luiz, um dos primeiros cursos de cinema de nível universitário no país.
} 
Khouri afirma o pioneirismo da crítica cinematográfica de Rubem Biáfora na atenção dispensada ao cinema japonês, do qual partilhavam o gosto pela linha intimista: "A influência dos intimistas da linha Gosho-Ozu-Naruse pode ser percebida no cinema de Rubem Biáfora [...] que foi um dos primeiros, senão o primeiro, a chamar a atenção para o cinema japonês, desde o primeiro momento de sua aparição, em sua coluna Indicações da semana".

Perguntado sobre quais críticos de cinema escreviam sobre filmes japoneses na época, o crítico Jean Claude Bernardet, que mantinha uma coluna sobre cinema no jornal A Última Hora, fala também do pioneirismo da geração de apreciadores do cinema japonês mencionada por Khouri, enfatizando o conhecimento e a valorização dessa cinematografia pela crítica paulista, especificamente por Rubem Biáfora, anteriores aos da crítica francesa da Cahiers $d u$ Cinéma. Ele descreve o teor da coluna Indicações da semana:

Parece que São Paulo foi uma coisa única no mundo, em que pessoas como o Biáfora conheciam e valorizavam cineastas como Mizoguchi ou Naruse, Ozu, antes dos franceses. [...] O Biáfora tinha essa coluna aos domingos, acredito, que se chamava Indicações da semana. Era uma pequena ficha técnica dos filmes que estavam entrando em cartaz, não lembro se era na segunda-feira. Em todo caso, ele anunciava os filmes que iam entrar em cartaz, havia uma ficha técnica e um pequeno comentário. Os filmes japoneses estavam lá com certeza.

\subsubsection{A crítica de cinema paulista: difusão do cinema japonês e divisão ideológica}

Teria a crítica de cinema, publicada nos jornais, desempenhado algum papel importante para a apreciação do cinema japonês pelo público não-nikkei? Jean Claude Bernardet argumenta que não: o prêmio conquistado em Veneza por Rashomon (1950) em 1951 foi o momento decisivo, a partir do qual o cinema japonês se deu a conhecer a públicos mais abertos, ou seja, foi a partir daí que o cinema japonês passou a existir para o público nãonikkei e não-cinéfilo. "Sobre esta base leitores brasileiros podem ler críticas de filmes japoneses escritos por críticos brasileiros. Mas eu não acredito que o gosto, a paixão do Biáfora, por exemplo, tenha tido qualquer influência sobre o meu pai, que ia bastante ao cinema". Por outro lado, a coluna Indicações da semana exercia forte influência sobre o público cinéfilo, independentemente das posições políticas e afinidades ideológicas:

[E para os já cinéfilos?] Ah, isto sim. O fato do Biáfora dar determinada dica na coluna Indicações da semana, que ocupava um grande espaço no jornal daquela época, podia sim chamar a atenção sobre determinado filme ou sobre um diretor que tinha realizado tal filme antes. Entre nós sim, eu lia as Indicações da semana sistematicamente. Eu não era o único que lia, mesmo sem ter grandes vínculos ideológicos com o Biáfora, era uma coluna de informação importante para nós naquela época e sistematicamente lida. 
O crítico de cinema e cineasta Alfredo Sternheim, que, como visto no capítulo anterior, foi parceiro de Biáfora na coluna publicada no jornal O Estado de S. Paulo de 1963 a 1967, narra um episódio em que uma crítica extensa e favorável, escrita por ele, a respeito de um filme de Tomu Uchida fez a platéia do Cine Niterói lotar, com um público formado em grande parte por não-nikkeis, alguns pertencentes à classe artística:

Quando a gente fazia, eu e o Biáfora, uma crítica louvável a um filme japonês que estava em exibição apenas em um desses cinemas, atraía muito público ocidental, um público fora da colônia. Então, eu me lembro quando eu fiz uma crítica do Espada diabólica, do Tomu Uchida, no Niterói, que eu coloquei nas alturas o filme, ou foi o outro, Koiya koi nasuna koi (Estranho amor, 1962), bom eu não sei, eu só sei que eu fui ver de novo o filme no sábado. Eu tinha permanente, não pagava, e eu tinha gostado tanto do filme que fiz um artigo enorme no Estado, naquela época o jornal não regulava muito espaço, se você tivesse vontade de escrever uma pagina inteira você podia, era uma maravilha. E eu fui ao cinema, estava o gerente, o pessoal me conhecia, e ele falou: "Está lotado, tem lugar só no balcão". Aí eu fui ver, encontrei um monte de ocidental, quer dizer, não da colônia, atrizes de teatro, como Cleide Yaconis, Walmor Chagas, todos tinham ido assistir ao filme naquela noite. E fiquei contente, porque era algo que era influência da minha crítica, que foi levou essas pessoas ao cinema. Fiquei muito feliz aquela noite ${ }^{65}$.

Jo Takahashi relembra que, no início dos anos 1960, um filme de Kaneto Shindo, Ilha nua (Hadaka no Shima, 1960), ficou em cartaz na cidade de São Paulo por mais de um mês, graças ao destaque concedido ao filme pelo jornal Folha de S. Paulo, que levou muitos espectadores a assistirem ao filme. No entanto, a aridez da linguagem do filme e da vida de seus personagens desagradou o público mediano:

Essa reverberação do cinema japonês na grande imprensa para mim foi uma surpresa, eu não acreditava que o cinema que parecia pertencer ao reduto da comunidade japonesa tivesse tanto alcance na imprensa brasileira. [...] Às vezes o cinema japonês escapava do circuito da Liberdade. Eu acredito que para o público era uma exibição, digamos assim, de um filme exótico. Mas a crítica sempre se manteve muito firme em promover o cinema japonês, tanto dentro do reduto da Liberdade, quanto fora. Eu lembro que a Folha de $S$. Paulo deu especial destaque para um filme do Kaneto Shindo chamado Ilha nua. Isso foi na década de 1960, em 1961 ou 1962. Ilha nua ficou em cartaz durante um mês, um mês e meio, mas sempre ocupando primeiro lugar da crítica. Isso arrastou muita gente aos cinemas. Mas o engraçado é que tinha muita gente que não gostava do filme, apesar de estar em primeiro lugar. Porque era um filme em branco e preto e sem palavras, eram apenas os efeitos sonoros e a música. Era um filme deslumbrante, mas para o público mediano era um absurdo um filme assim, que na verdade não tem propriamente uma história, tem uma

\footnotetext{
${ }^{65}$ É possível que a crítica e o episódio a que se refere Sternheim sejam relacionados a um outro filme. De acordo com o livro Cinema Japonês (1964), Espada diabólica (Daibosatsu Tôge), a trilogia de Tomu Uchida, foi exibida no Cine Niterói entre 1958 e 1960. Já o filme Estranho amor (Koiya koi nasuna koi) foi exibido em janeiro de 1963 (Oliveira, 1964: 37), três meses antes de Sternheim assumir a vaga de Fernando Seplinski como segundo crítico da coluna Indicações da semana, em março de 1963 (Trunk, 2007). Outra possibilidade é uma incorreção nas datas de exibição dos filmes indicadas pelo livro de 1964.
} 
narrativa de uma família que mora numa ilha. Isso provocou uma certa surpresa, o filme acabou ganhando o prêmio da Folha de melhor filme do ano, mas não foi a escolha do público, não era um blockbuster.

Em março de 1966, o cineasta paulista Roberto Santos lançou o filme A hora e a vez de Augusto Matraga na cidade de São Paulo. De acordo com Inimá Simões (1997), o público paulistano quase ignorou o filme, tendo ele permanecido apenas duas semanas em cartaz. Veremos mais adiante como esse filme de Roberto Santos se relaciona com o cinema japonês e com as salas de exibição da Liberdade. O escritor Ignácio de Loyola Brandão protestou contra a retirada precoce do filme de cartaz, em sua coluna no jornal A Última Hora. Simões observa que a não-ressonância do protesto de Ignácio de Loyola e fracasso de público do filme em São Paulo refletem a divisão ideológica do núcleo de cinema paulista, ou seja, dos cineastas, críticos e cinéfilos da cidade:

Em São Paulo, apesar da militância de grandes críticos, não havia, como no Rio, uma unidade em torno da questão do cinema nacional, um núcleo de formulação de políticas, uma reverberação tão forte do pensamento do Cinema Novo, para citar um exemplo. Quando Ignácio de Loyola reclama do que aconteceu com a carreira do filme, segundo ele, encerrada prematuramente nos cinemas da capital, não há ressonância a não ser entre os jovens jornalistas. O núcleo paulistano - entenda-se críticos, cinéfilos, cineastas, etc. - está muito mais dividido ideologicamente que no Rio. Em conseqüência, a carreira de Matraga é muito mais bem sucedida nos cinemas cariocas que aqui (Simões, 1997: 90).

Alfredo Sternheim comenta sobre a relação entre os críticos de São Paulo que escreviam sobre o cinema japonês na época. Seus amigos que o acompanhavam, eventualmente, às salas da Liberdade eram Rubem Biáfora, Walter Hugo Khouri, José Fioroni Rodrigues e Fernando Seplinski. No depoimento de Sternheim há algumas polarizações colocadas em termos de análises, gostos e opiniões: ele se afinava com Biáfora, seu mentor e colega de redação, enquanto que divergia de Orlando Parolini e Jairo Ferreira, parceiros, em 1966, da coluna sobre cinema no jornal São Paulo Shimbun. A freqüência com que ele e Biáfora escreviam sobre o cinema japonês é contrastada com a intermitência das críticas de Brandão sobre os filmes desta cinematografia, assim como a limitação do jornal A Última Hora, com o tamanho de O Estado de S. Paulo:

O Inácio chegou a escreveu sobre filme japoneses na A Última Hora, é verdade, mas não era uma coluna só sobre cinema. Teve uma época que foi só sobre cinema. [Como é a relação entre vocês, os críticos de cinema japonês?] Havia divergências entre os críticos. Eu me afinava mais com o gosto do Biáfora, do que, por exemplo, com o do Jairo e do Parolini. Eu me lembro que opinativamente eu não me afinava muito com as análises nem dele, nem do Jairo. O Inácio era esporádico as críticas dele sobre cinema japonês, eu não lembro direito, 
não era tão freqüente como a nossa no Estadão. Mas eu acho que era pela própria limitação do jornal que ele escrevia que era A Última Hora.

O escritor Cládio Willer emite sua opinião sobre os críticos Rubem Biáfora e Alfredo Sternheim. Se naquela época o grupo dele definia ambos como "críticos fascistas de cinema", atualmente Willer não diria isso sobre Sternheim, que parece ser mais criticado pela proximidade e influência de Biáfora do que por suas posições pessoais. No entanto, Willer reafirma algumas críticas em relação a certas características de Biáfora, como o facciosismo, o reacionarismo e o temperamento idiossincrático. Por outro lado, a valorização da obra de Ingmar Bergman por Biáfora é reconhecida, assim como a dimensão e a importância da crítica de cinema da época como um todo:

Eu não gostava do Biáfora como crítico de cinema. Eu o achava faccioso, idiossincrático, nunca gostei. Muito informado, chamou a atenção para Bergman e tal, mas eu não gostava. [...] A gente chamava eles, ele e o Sternheim, que é uma boa pessoa, de críticos fascistas de cinema. [...] Mas ele era boa pessoa, hoje em dia eu não diria que ele é fascista. Ele tinha o viés Biáfora. O Biáfora era reacionário, enviesado, idiossincrático. Tinha aquilo que ele gostava e aquilo que ele atacava. Na época em que a crítica de cinema era importante, formava opinião, indicava. Hoje em dia não, hoje em dia é mera resenha.

O cineasta João Batista de Andrade relembra a importância da descoberta do Neo Realismo italiano para a sua geração, que ele define como "o núcleo do Cinema Novo tardio de São Paulo". Para Andrade, esse grupo se formou com o encontro, em 1963, dos cineastas Vladimir Herzog, Fernando Birri, Jean Claude Bernardet, Rudá de Andrade, Roberto Santos, Luís Sérgio Person, Maurice Capovilla, Francisco Ramalho, José Silvério Trevisan, além dele.

Em sua fala é perceptível, por um lado, a identificação com o projeto do Cinema Novo carioca e, por outro, uma diferenciação com relação ao grupo dos cineastas Rogério Sganzerla e Carlos Reichenbach: “eles já vinham com críticas sobre o Cinema Novo, nós não, a minha formação é Cinema Novo. Neo Realismo desembocando no Cinema Novo, e um Cinema Novo latino-americano, principalmente através do Fernando Birri”. ${ }^{66}$ Na reflexão sobre o neorealismo, arte e política e se misturam, e a busca da beleza nas contradições da realidade social

\footnotetext{
${ }^{66}$ De acordo com ele, essa diferença surgiu com o golpe de 1964: “A diferença dessa geração que surge depois de 1964, mesmo que tenha começado antes, mas é uma geração típica de depois de 1964, porque isso criou para nós um problema: nós ficamos inviáveis. Então para essa geração nova, a gente era a pior proposta. Tanto é que o Cinema Novo continua realizando coisas, e vou lá em 1967 e faço Liberdade de imprensa com a mesma liberdade, com o espírito crítico, com a criatividade própria de minha geração que continuava peitando, que continuava acreditando naquilo e criticando. Resultado: meu filme é apreendido antes de exibir. Eu era inviável. Então que relação que estas pessoas novas tinham com uma proposta como a minha? Como a minha, com a do Glauber, com a do Joaquim, com a do Leon, essa é que é a verdade. Quer dizer, nós éramos inviáveis para eles".
} 
- presente no Neo Realismo, no Cinema Novo, e no documentário latino-americano -, é contrastado com a beleza glamourosa do star system norte-americano:

Eu estava encantando com esta possibilidade de, com a sua inteligência, com a sua percepção e com o seu senso crítico, fazer coisas belas sobre o que aparentemente é feio. Como Rosselini fazia com aquela Itália destruída, aqueles personagens desempregados, malandros, de repente aquilo virava o belo. Você descobria que o belo estava em outro lugar, não estava no glamour das estrelas e dos astros. Isso é uma descoberta da época, da minha geração e que se aprofundou depois, para mim pessoalmente, com o conhecimento de um cineasta argentino que é um mestre, que é o Fernando Birri.

Assim como Willer, João Batista de Andrade recorda-se que seu grupo considerava a dupla Sternheim e Biáfora como os críticos de direita. Essa discussão, no entanto, é remetida ao campo do cinema: Biáfora era contra o Cinema Novo e a favor de cinema de glamour e escapista. Trata-se do mesmo conflito mencionado por Sternheim: "Havia essa idiossincrasia de que o Cinema Novo era esquerda festiva, e que Khouri e Biáfora eram alienados - eram as palavras da época". Nesse embate, Andrade observa uma certa linhagem ou escola de crítica cinematográfica, encabeçada por Biáfora e seguida por Sternheim, Rubens Ewald Filho e Carlos Motta, sobre quem, apesar dos antagonismos grupais, ele conta um episódio marcante:

A gente considerava o Alfredo e principalmente o Biáfora como os críticos de direita. Ele era contra o Cinema Novo, defendia um cinema mais de glamour, o cinema pelo cinema. $\mathrm{O}$ prazer do cinema está naquilo que o filme apresenta como sonho. Então eles não se davam bem com o Cinema Novo de jeito nenhum, não se davam bem comigo, nem o Biáfora, nem o Alfredinho. Alfredinho, já mais novo, era seguidor do Biáfora, assim como Rubens Ewald [Filho], que também não se dava com o Cinema Novo. Era também na linha do Rubem Biáfora, embora as relações não fossem totalmente negativas. Com o Biáfora era mais difícil, mas eu me relacionava com ele. E tinha um outro seguidor dele que escrevia no Estado. Como é que chama? [Carlos Motta?] Carlos Motta, que também tinha esse perfil mais conservador de cinema. O Biáfora fez escola. Mas quando eu ganhei o Festival de Moscou em 1981, o Motta escreveu um artigo enorme, assim: "Um prêmio a uma carreira de lutas". Uma matéria grande, altamente elogiosa a mim, como cineasta ligado a uma luta permanente, de um cinema aguerrido e tal. Eu fiquei emocionado com isso.

Jean Claude Bernardet narra um episódio marcante em seus anos de formação, envolvendo duas importantes referências para ele - Rubem Biáfora e Paulo Emílio Sales Gomes. Um comentário de Biáfora a respeito de um filme de Robert Bresson revela o dogmatismo do parâmetro cinematográfico adotado por ele: a narrativa clássica dos filmes norte-americanos das décadas de 1930 a 1950, excluindo o que fugisse disso. Uma aula ministrada por Gomes na Cinemateca Brasileira, durante um curso de formação para dirigentes de cineclube, teve um efeito de libertação para Bernardet: 
Eu tive uma indiscutível relação com o Biáfora. Porque ele amava o cinema e isto fez parte da minha formação. Eu lembro ter dado um texto meu para o Biáfora ler, isto no Tourist Bar, sobre um filme de Robert Bresson chamado Les dames du Bois de Boulogne (1945). Eu tinha escrito alguma coisa, o Biáfora tinha lido, e ele me disse que tinha gostado muito do texto, mas que eu encontraria coisas muito melhores nessa linha, no cinema americano. $\mathrm{O}$ Biáfora tinha uma percepção de cinema absolutamente dogmática, e o que saía do dogma, simplesmente não era cinema. Então não vai falar em cinema francês ou cinema italiano, aquilo não existia, porque o dogma era o americano e ponto final. $\mathrm{O}$ que me livrou disto, felizmente, foi o Paulo Emílio Sales Gomes, numa aula em que ele afirmou, na sua forma tão paradoxal de falar, mas tão marcante: "O cinema não existe, existem os filmes". Depois deste momento eu me senti absolutamente livre do Biáfora, porque cada filme é um filme, então não precisa respeitar esta ou aquela estética, cada filme se realiza na sua própria direção. Isto para mim foi a libertação. Eu achei aquilo maravilhoso, quer dizer, são esses momentos absolutamente marcantes, quando você está no processo de formação. Foi o momento em que eu me distanciei totalmente de Biáfora, de Khouri um pouco menos, quer dizer, achei que precisava ir numa outra direção, eu rejeitava aquilo. O que não impedia que eu continuasse a ler as Indicações da semana, porque era uma fonte de informação muito boa, era uma coisa muito sistemática. Que eles eram de direita, sim, isso não tem dúvida. Mas não é só isso, é que cinematograficamente eles estavam bitolados. [Em que sentido?] De que só existe um cinema. Para o Biáfora, você saía do cinema americano dos anos 1930, 1940 e 1950, você saia de um certo cinema japonês, não tinha mais nada. Não vai falar em Rosselini, Rosselini não era cinema! Aquilo não é cinema, nunca foi, nunca será e não tem nenhuma hipótese que possa vir a ser. Era um xiita o Biáfora.

E o que escrevia Rubem Biáfora a respeito dessas questões e do ambiente político na época? Numa crítica a Mar de rosas, filme da cineasta Ana Carolina, ele deixa claro sua posição no debate da época: "A formação de Ana Carolina foi a de uma típica intelectual local nas duas últimas décadas. Décadas nas quais o mal maior não foi a própria (ou impropriamente?) a ditadura, mas a mediocridade generalizada e inarredável e, sobretudo, o "macaqueamento" e o dirigismo cultural [...]" (Biáfora, 1978a: 35). Na crítica a Doramundo, de João Batista de Andrade, transparece o pensamento de Biáfora acerca dos cineclubes e da Cinemateca Brasileira: “[...] João Batista de Andrade com sua formação "dirigidamente política" da maioria daqueles que aqui se formaram em cineclubes e nas águas mais proselíticas que cinematográficas da Cinemateca Brasileira [...]” (Idem, 1978b: 41).

Em entrevista concedida por Biáfora em 1986, ele opõe o código moral vigente nos filmes dos estúdios norte-americanos ao oportunismo do Neo Realismo, especialmente de Roberto Rossellini:

Havia uma ética nos filmes [...] não se arriscavam a fazer uma pessoa cuspindo em cena, não podiam fazer um espectador sequer se sentir mal, e não era bitolamento, não. [...] No cinema todo mundo se mantinha num tom. Será que isso se devia à quantidade de filmes testados juntos ao público? O gozado é que as pessoas falavam que era cor de rosa, água com açúcar, que queriam realismo, mais fora da vergonha na cara, ou da luta por qualquer decência ou fora de qualquer raciocínio eram as que mais se arvoravam em juízes. Eu me lembro de alguns antigos militantes de esquerda que quando surgiu Roma, cidade aberta disseram: "O povo não quer mais esta bobagem, esse pó de arroz, o povo quer a verdade !". 
Dizer que Roma, cidade aberta é a verdade é uma piada. O filme é uma comédia popularesca, que só tinha mesmo de decente a Anna Magnani. Eu sei como o Rossellini fez o filme: parentes próximos me disseram que ele ficou revoltado vendo um padre ser assassinado e se trancou num porão e resolveu fazer um filme.

O engajamento político associado ao cinema produziu filmes de qualidade indiscutível e inspirou importantes movimentos cinematográficos, como o Neo Realismo, o Cinema Novo e o documentário latino-americano. Mas ele produziu também uma espécie de efeito colateral perverso: o patrulhamento ideológico que incidia sobre os gostos e escolhas cinematográficas dos espectadores, gerando o que Carlos Reichenbach chama de guilty pleasures, uma forma particular de resistência a esse patrulhamento:

\begin{abstract}
Mas eu percebo com clareza que naquela época, mesmo no contexto em que eu escondesse dos meus amigos, eu não tinha preconceito contra gênero [cinematográfico] nenhum. Podia não confessar para os meus amigos: "Puta, estou vendo filme do Maciste escondido", etc. e tal, ninguém precisava ficar sabendo dos filmes do Maciste, filme de erotismo, sei lá qualquer coisa, aliás, essas coisas não tinha muito que ficar comentando para babaca, eu me lembro que naquela época o nível de cobrança era muito grande, em todos os sentidos. [De patrulhamento?] Mas um patrulhamento excessivo, não era só no nível político. Como você vai gostar deste filme alienado? Como que você vai gostar de cinema comercial? Como é que você vai gostar de filme italiano, bangue-bangue italiano? Você escondia, guilty pleasure, prazer proibido [risos]. Era o teu segredo. Tem umas coisas que você tem que guardar para você, porque no fundo, são coisas muito tuas, os outros que se fodam.
\end{abstract}

Jean Claude Bernardet fala também do patrulhamento ideológico da época, que colocava o político como critério absoluto de avaliação dos filmes. Isso fica evidente na comparação que ele estabelece entre os filmes Harakiri (Seppuku, 1962), de Masaki Kobayashi, e $O$ ano passado em Marienbad (L'année dernière a Marienbad, 1961), dirigido por Alain Resnais, e no relato de um episódio relacionado à recepção do filme francês:

Agora isto implica em eventuais contradições nas pessoas. Uma destas pessoas sendo eu. Para mim, Harakiri era um extraordinário equilíbrio de um formalismo poderoso e expressivo com uma postura política. De forma que o Harakiri não me colocava maiores problemas, porque era uma obra prima absoluta. Onde eu tive a crise foi com $O$ ano passado em Marienbad. A SAC [Sociedade Amigos da Cinemateca] fez a pré-estréia, eu trabalhei nisto, na Cinemateca [Brasileira], na SAC naquele momento, e na pré-estréia, à meia-noite na saída, todos os meus amigos que eram comunistas odiaram este filme, que era a própria cultura burguesa decadente. E saímos do [Cine] Coral, e eu ouvindo-os xingarem, criticarem este filme que eu tinha adorado. E aí me lembro que eu voltei para o Coral, naquela hora com as portas fechadas e tudo. Sentei na frente do cinema e chorei, porque eu não sabia como resolver essas contradições, de um filme que não era abertamente político e que eu absolutamente adorei, até hoje considero Marienbad um grande filme. Mas eu não tive isto com o cinema japonês, porque o equilíbrio perfeito era o Harakiri. 


\subsubsection{Cineclubismo e cinefilia}

Ao analisar a formação do circuito de cinema de arte na cidade de São Paulo, Inimá Simões (1982) chama a atenção para a formação de um público diferenciado, de extrato universitário, com conhecimento da linguagem cinematográfica e disposto a discutir o papel do cinema na vida cultural do país. Para Simões, diversos fatores atuaram para a formação desse público: a proliferação dos cineclubes, o aumento do número de estudantes universitários, a atuação irradiadora da Cinemateca Brasileira e a agitação cultural da década de 1960, que teve no Cinema Novo uma de suas mais conhecidas expressões (Simões, 1982: 128).

Esse processo pode ser exemplificado pela descrição que Sedi Hirano faz de Irineu Ribeiro dos Santos, colega do secundário, militante comunista e amigo, que o apresentou ao cinema japonês: "O gosto pelo cinema japonês quem me introduziu foi esse amigo meu. [...] Ele adorava o cinema japonês, mas adorava o Neo Realismo italiano: Ladrões de bicicleta, o Cinema Novo. O pessoal não cultivava apenas o cinema japonês, cultivava o cinema como um todo, as várias linhas". No livro Roberto Santos: a hora e a vez de um cineasta, Inima Simões (1997) descreve a rua Sete de Abril como o epicentro da agitação cultural e política da época:

Até o início dos anos 60 São Paulo gravitava em torno de uma região central ampliada [...] formada pelos cinemas, restaurantes, livrarias, teatros, leiterias, confeitarias, hotéis, bares, auditórios de rádio e museus. Da praça da Sé à praça da República formava-se um eixo poderoso por onde fluía parte significativa da multidão e onde acontecia de tudo. A rua Sete de Abril sediava vários endereços. O MASP era um dos pólos de irradiação da informação artística. A Sociedade Amigos da Cinemateca era outro. O Bar do Museu de Arte Moderna, um ponto de encontro assim como era o Costa do Sol, na mesma rua, ou ainda o Cine Coral logo adiante, o primeiro a exibir comercialmente os filmes de Fellini. À pequena multidão que freqüentava esses pontos se juntavam os jornalistas dos Diários Associados e do jornal $O$ Estado de S. Paulo, cujas redações ficavam próximas. Terminado o horário comercial a agitação continuava, porque a vida noturna se concentrava ali e nas imediações. Era possível ir a pé de um lugar para o outro sem maiores dificuldades. Um pouco além ficavam as faculdades de Filosofia e de Arquitetura da USP, as instalações do Mackenzie e até a sede da TFP, que já demonstrava sérias preocupações com a ameaça comunista que parecia cada dia mais concreta (Simões, 1997: 69).

Em meados da década de 1950 a cidade de São Paulo apresentava uma paisagem cinematográfica variada, apesar do predomínio absoluto dos filmes norte-americanos nas salas de cinema da cidade, como vimos no capítulo anterior. Jean Claude Bernardet fala de um cinema localizado na região central descrita por Simões, o Cine Jussara, freqüentado por ele junto com a família pela mesma razão que levava os imigrantes japoneses e seus descendentes aos cinemas da Liberdade: "Havia ainda uma certa força do cinema europeu, principalmente 
italiano e francês. Então havia uma sala na rua Dom José de Barros, que se chamava Jussara. Durante os anos 1950 eu freqüentei muito com a minha família, porque era um lugar onde se podiam ver filmes franceses e italianos”. Alfredo Sternheim atribui à presença de filmes das cinematografias mexicana, italiana, francesa e, especialmente, a japonesa com suas quatro salas, ao fato de São Paulo ter se transformado num centro cinematográfico mais cosmopolita:

O cinema mexicano tinha penetração em São Paulo, tinha muito. E a Itália também, com filmes melodramáticos, como Os filhos de ninguém. Quer dizer, São Paulo, de repente, começou a ficar uma capital do cinema mais cosmopolita, não ficou só a hegemonia do cinema americano. Claro, o cinema americano mandava, dominava, mas começou a ter vez o cinema francês e o cinema japonês que, no final dos anos 1950, tinham quatro salas em São Paulo.

Cláudio Willer menciona o Cine Áurea, localizado na mesma região, que exibia os filmes da nouvelle vague francesa e o mesmo Cine Jussara citado por Bernardet, que na década de 1960 exibiu os filmes suecos de Ingmar Bergman. Na década anterior, a presença de filmes comerciais de vários países, como as comédias italianas, é lembrada:

Em 1960, você tinha aquele cinema da Rua Aurora, o Áurea, passando Jean-Luc Godard, tinha o Bergman passando no Cine Jussara, tinha os japoneses, quer dizer, era de um ecletismo extraordinário. E aquelas maravilhosas comédias italianas. Aldo Fabrizi [19051990], o Steno [1915-1988], Totò [1898-1967], tudo isso na década de 1950, quer dizer, você tinha um cardápio completo de programações, tinha o cinema americano forte, sempre foi o mais forte, mas com a presença do cinema comercial italiano e brasileiro, com público, o cinema francês, o mexicano etc. Sem dúvida alguma houve um afunilamento.

Havia, no entanto, muitas outras cinematografias que não conseguiam furar o bloqueio da associação dos distribuidores norte-americanos com os nacionais nos cinemas da cidade. Inimá Simões comenta que antes do surgimento do Cine Coral, mesmo filmes de prestígio internacional, isto é, vencedores de premiações em festivais de cinema, não eram importados pelos exibidores sob a alegação de que o cinema europeu moderno não seria rentável (Simões, 1982: 128). Bernardet cita diversos festivais de cinema nacionais, como o tcheco, o polonês, o russo e soviético, promovidos pela Cinemateca Brasileira, cujos filmes não seriam exibidos no circuito comercial de cinema de São Paulo:

Quanto ao cinema polonês e ao cinema tcheco, que eu saiba, não havia nenhuma penetração desses cinemas mas possível que uma ou outra fita tenha conseguido furar o bloqueio. Agora, o que aconteceu com o cinema tcheco e com o cinema polonês é que a Cinemateca fez festivais e, nesta época, eu já estava trabalhando lá. [...] Fizemos também o festival do cinema russo e soviético. Além disto, fizemos o festival do cinema francês e do cinema italiano. Do francês e do italiano, havia filmes circulando em retrospectivas, coisas que não estavam passando normalmente. Agora, a exibição dos filmes soviéticos, tchecos e 
poloneses, além de um ou outro que possa ter furado o bloqueio por causa de algum prêmio em Veneza ou Cannes, é a Cinemateca que produziu.

Além dos festivais citados por Bernardet, em agosto de 1957 a Cinemateca Brasileira realizou, em parceria com o Cine Niterói, o ciclo Cinema Japonês Moderno, conforme mencionado no primeiro capítulo. Após 1963 a Sociedade Amigos da Cinemateca [SAC], na qual atuaram Jean Claude Bernardet e João Batista de Andrade, passou a organizar as mostras e festivais de cinema da Cinemateca. Cláudio Willer fala da importância das sessões e festivais de cinema promovidos pela SAC para a formação cinematográfica de sua geração, justamente no momento da mudança de paradigma cinematográfico suscitado pela nouvelle vague e pelo cinema italiano moderno:

[Você participou de cineclube, como o da SAC?] Como freqüentávamos! Sessenta e pouco, quando era na Sete de Abril, e funcionou lá a SAC com suas projeções naquele pequeno auditório, vi tudo. Foi igual, digamos assim, a ter um curso de cinema. Os clássicos franceses e o esteticismo, os grandes clássicos como o Nosferatu (Nosferatu, eine Symphonie des Grauens, 1920), o Caligari (Das Cabinet des Dr. Caligari, 1920), o expressionismo alemão. Teve ciclo de tudo, cinema de vanguarda nova-iorquino, era uma programação muito boa. Eu lembro que em 1963 tinha um amigo nosso, poeta surrealista, o Sérgio Lima, que trabalhava na Cinemateca e a gente fazia reuniões de surrealismo com ele. Quando passou L'âge d'or (1930) do Buñuel, o Piva, eu, o Sérgio Lima, o Décio Bar, Guilherme de Farias e outros amigos, nós chegamos, ocupamos uma fila e o Antunes Filho entrou, olhou para a gente e apontou o dedo assim: "Poetas malditos! Poetas malditos!" [risos]. Aquela programação da Cinemateca no tempo da Sete de Abril foi fundamental para a nossa formação cinematográfica. Ao mesmo tempo, foi a época da revolução cinematográfica com a nouvelle vague e os italianos, Fellini e Antonioni. Quer dizer, foi quando houve uma virada, uma mudança de paradigmas de cinema.

João Batista de Andrade descreve sua experiência com o cineclubismo. Nascido em Ituiutaba, Minas Gerais, ele emigra para a cidade de São Paulo em 1960 para cursar o curso de engenharia na Faculdade Politécnica da Universidade de São Paulo (USP). Em 1962, na mesma época em que ingressa no Partido Comunista Brasileiro (PCB), Andrade cria o grupo Kuatro, junto com o cineasta Francisco Ramalho Jr. Trata-se de um grupo de cineclube que exibia filmes na Faculdade de Filosofia da USP na rua Maria Antônia, na Faculdade de Arquitetura e Urbanismo, localizada na rua Maranhão e na Faculdade de Medicina, na avenida Dr. Arnaldo. "Eu pegava o projetor, alugava o filme ia lá e exibia, fazia panfleto, ia lá debater depois, isso em 1963". Ele fala sobre o tortuoso processo de pesquisa dos filmes e sobre a diversidade cinematográfica revelada pela pesquisa e exibida nas sessões do cineclube:

Quando eu comecei minhas atividades de cineclube, em 1962, por aí, o desejo de conhecer outras cinematografias era grande. Tanto é que descobri a cinematografia do Canadá, da Polônia, da Tchecoslováquia, da Hungria, da União Soviética, a cinematografia japonesa e 
mexicana também, tinha um Cinema Novo no México, com o filme Raices (1954, Benito Alazraki), por exemplo, que passou aqui, o Fernando Birri, o cinema argentino. Então havia uma busca de outras cinematografias, mas era um sinal também que este cinema não estava no mercado. Tinha que buscar. [...] Pegava na embaixada aqui da Polônia, então a gente tomava contato, porque começava a procurar: cinema japonês, cinema polonês, canadense e tcheco a gente acabava achando, principalmente nas embaixadas. E aí exibimos bastante isso. A gente aprendeu o caminho das pedras.

Jean Claude Benardet define o significado da palavra cinefilia e situa sua importância para a formação cinematográfica de sua geração. Se, por um lado isso se constituiu como uma das bases do cinema francês das décadas de 1940 e 1950, isto é, foi um processo da história do cinema mundial, por outro, de 1955 a 1965, a cinefilia adquiriu um significado próprio na cidade de São Paulo - o primeiro curso superior de cinema do Brasil foi criado em 1965 na Universidade de Brasília por Paulo Emílio Sales Gomes, do qual o próprio Bernardet fazia parte do corpo docente. Antes disso, a formação cinematográfica do "núcleo paulista" de cinema resumiu-se à participação em filmagens e edições de produções em curso, às leituras de bibliografia estrangeira, mas principalmente à cinefilia e ao cineclubismo:

Tem uma palavra chave para esta época, que é a palavra cinefilia. Essa é a época da cinefilia, que significa uma série de coisas. Significa um amadorismo, no sentido de amar o cinema. E não foi só o brasileiro, quer dizer, isto é uma das bases inclusive do movimento cinematográfico francês do fim dos anos 1940 e dos anos 1950. Então esse amor ao cinema significa ver muitos filmes, mas significa também uma outra coisa. É que não havia escolas de cinema. A cinefilia significa também se formar pelo cinema. Aqueles que continuaram no cinema, produzindo, realizando ou como críticos, são pessoas que se formaram em cinema vendo cinema, não se formaram em escolas. Havia pequenos cursos aqui em São Paulo promovidos pela Secretaria da Cultura, que eram cursos de uma semana, sobre montagem, história do cinema, coisas que começaram a aparecer, mas que pingava, não havia formação. Então a nossa formação, mas isso é Glauber, é Joaquim Pedro, Gustavo Dahl, eu, somos todos nós, somos formados vendo filmes, discutindo filmes, discutindo de uma forma sistemática, o que significa cineclube. Cineclube que pode ser um lugar onde também se exibem filmes, no caso, por exemplo, do cineclube da Politécnica de que fala o João Batista, ou o cineclube da Física no Rio, onde estava o Joaquim Pedro, ou em Salvador, o cineclube do Walter da Silveira, mas podia haver cineclubes que não exibiam filmes. O exemplo era aquela ao qual o Gustavo Dahl e eu estávamos ligados, que é o do [Centro] Dom Vital: nós nunca exibimos filmes. Trabalhávamos com filmes em cartaz, então nossa atividade era essencialmente uma atividade de discussão. E líamos muito. Líamos tanto livros sobre cinema, quanto revistas. Prioritariamente revistas de origem européia, francesas e italianas. Então foram esses pontos que nos formavam. O primeiro curso de cinema no Brasil foi fundado em Brasília, em 1965, pelo Paulo Emílio Sales Gomes, e que durou apenas alguns meses devido à crise militar.

E foram justamente a cinefilia e o trabalho de cineclubismo que levaram João Batista de Andrade às salas de cinema da Liberdade. Da mesma forma como descobriu o cinema polonês e o tcheco, o cinema japonês despertou o seu interesse: "E descobri que era uma das cinematografias das mais poderosas do mundo. Uma cinematografia tão poderosa quanto a 
italiana, quanto a americana, com uma diversidade muito grande". Numa experiência análoga àquela em que o escritor João Antônio sentiu o preconceito de raça, Andrade, ao contrário, define a condição dos cinéfilos não-nikkeis naquelas salas como penetras numa festa de família:

Eu me lembro disso, que muitas vezes ia ao cinema e eu era o único não-japonês. Mas daí eu também pensava um pouco o seguinte: essas pessoas são migrantes, estão fora do país delas. [...] Então aí a gente parece que entrava numa festa de família. Como curiosos, ou entrava como furão na festa de família. Eu tinha um pouco este sensação. Eu não tinha essa sensação de preconceito das pessoas porque eu não era japonês. Eu pensava que as pessoas achavam isso curioso. Às vezes ficam me olhando, mas eu sempre pensava isso, penetras numa festa de família. O cinema para eles, eu acho que tinha mais o significado de contato deles com eles mesmo, com a origem, do que propriamente como cinema. Talvez lá dentro tivesse o prazer estético do cinema. Mas ir ao cinema era ir ao Japão, era ver as figuras, ver as caras dos japoneses.

\subsubsection{Influências do cinema japonês no cinema paulista}

Como visto no capítulo anterior, Walter Hugo Khouri ficou marcado pelo "cinema intimista japonês", filmes dos cineastas Mikio Naruse, Yasujiro Ozu, Heinosuke Gosho e Hideo Ohba sobre cotidiano de pessoas de diversas classes sociais. Khouri reconhece a influência desses cineastas em seus filmes produzidos a partir dos anos 1970, e no segundo longa-metragem dirigido por Rubem Biáfora, O quarto (1967). Esse cinema intimista autêntico é contraposto aos filmes de época de Akira Kurosawa e Kenji Mizoguchi, marcados pela presença de elementos típicos e exóticos.

Jean Claude Bernardet, no entanto, valoriza justamente a atualidade de Rashomon (1950), um filme de época de Kurosawa. Outro filme marcante para ele é Harakiri (Seppuku, 1960), de Masaki Kobayashi, equilíbrio perfeito entre postura política e formalismo expressivo. Um terceiro filme importante para Bernardet é Juramento da obediência (Bushidô zankoku monogatari, 1963), dirigido por Tadashi Imai, do qual deduziu uma estrutura de cinema ensaístico que inspirou a elaboração de $A$ hora dos ruminantes, roteiro escrito em parceria com Luis Sergio Person e nunca filmado.

Para Carlos Reichenbach, o contato freqüente com o cinema japonês significou "um machado na cabeça":

Uma abertura de percepção e de entendimento da linguagem cinematográfica que foi deflagradora. Eu teria uma coisa muito mais careta, muito mais acadêmica, se o cinema japonês não tivesse entrado na minha vida. Para mim foi uma experiência libertadora, transformadora e transgressiva. 
Reichenbach reconhece a influência de quatro cineastas japoneses - Eizo Sugawa, Yasuzo Masumura, Shohei Imamura e Kenji Mizoguchi - em filmes dirigidos por ele em várias épocas. Ele valoriza a presença de elementos naturais e sobrenaturais no cinema de Mizoguchi, sua a atmosfera mítica e a maneira como manifestações da natureza metaforizam sentimentos dos personagens, elementos presentes também nos filmes Dois Córregos e Alma corsária:

O que me interessava no Mizoguchi era o lado mais mítico, a lenda, a presença do rio, do barco, isso que está muito presente em Intendente Sansho e Contos da lua vaga, de como a manifestação da natureza coloca em questão, explicita sentimentos. Acho que onde vai ter essa marca do Mizoguchi é em Dois Córregos. A presença do rio, a presença de pessoas que estão em barcos à deriva. Alma corsária tem a figura da morte, uma mulher de negro que vem buscar as pessoas. Aquilo está nos filmes do Mizoguchi. E também pela forma de enxergar a morte como um rito de passagem, nada mais budista. A morte não é enxergada nesses filmes como um ato de punição, mas talvez até como um ato de libertação. Eu acho que isso é o que me fascina, essa visão poética.

Vimos no primeiro capítulo a afinidade estabelecida entre os filmes dos cineastas da nouvelle vague japonesa, exibidos principalmente no Cine Nikkatsu, com o movimento cinematográfico do qual Reichenbach fez parte, conhecido como Cinema Marginal ou de Invenção, do qual participaram também os cineastas Rogério Sganzerla, Andrea Tonacci, Ozualdo Candeias, Jairo Ferreira e João Callegaro. Reichenbach fala da influência de Yasuzo Masumura, especialmente da relação entre uma tese formulada pelo cineasta japonês e filmes seus como Lílian M. relatório confidencial, Amor, palavra prostituta e Garotas do ABC:

Uma grande influência foi de um diretor pouco conhecido chamado Yasuzo Masumura, que filmou os melhores livros do Kawabata e que fazia filmes eminentemente feministas. Não é que ele fazia o elogio das prostitutas, mas ele enxergava uma forma de libertação. Eu li uma entrevista com o Masumura que define bem inclusive os filmes que eu viria fazer algum tempo depois: Lílian M. relatório confidencial, Amor, palavra prostituta e os filmes sobre as operárias. Em seus filmes, toda vez que falam dessa condição de libertação da mulher são sempre filmes envolvendo violência, então ele dizia uma frase: "Você tem que entender que mais do que para o homem, para a mulher, o sangue está presente em qualquer experiência essencial e inicial marcante da vida. Do parto à primeira regra". Isso é louco! Masumura para mim foi essencial, importantíssimo. Eu falo como uma das influências mais importantes de Lílian $M$.

No que consiste esse olhar de Masumura ao feminino, que repercutiu em certos filmes de Reichenbach? A questão do sangue surge explicitamente em Amor, palavra prostituta (1978), um dos primeiros filmes brasileiros a abordar a questão do aborto de maneira conseqüente. "Masumura sempre tem personagens femininas muito fortes, energizadas, que conseguem driblar o ambiente machista e violento". A frase, no entanto, parece ser boa 
também para definir alguns filmes do cineasta brasileiro. A visão afetiva em relação às personagens femininas, imersas em ambientes machistas povoados por figuras masculinas contraditórias, parece constituir o elo entre as obras de Masumura e Reichenbach:

Eu acho que é exatamente essa visão a respeito do universo feminino, uma visão mais moderna, mais carinhosa, mais afetiva. Os filmes do Masumura são muito afetivos com relação às figuras femininas e esses filmes falam de um processo de libertação em que a figura do masculino é sempre cheia de contradições. Anjos do arrabalde é um filme sobre um universo onde as mulheres trabalham convivendo com a violência do meio social, machista. Todos os outros filmes têm um pouco esta relação: Amor, palavra prostituta etc. Então eu acho que estes temas vão encontrar uma ressonância nesses filmes japoneses.

Dois cineastas japoneses realizaram filmes que marcaram especialmente João Batista de Andrade: Tadashi Imai, como Juramento da obediência, e Nagisa Oshima, com dois filmes dirigidos em 1960 - Noite e névoa sobre o Japão (Nippon no Yoru to Kiri) e O túmulo do sol (Taiyo no Hakaba). Em relação ao primeiro, Andrade lembra-se do clima de desespero dos jovens: "Do desespero dos jovens e de coisas que lembrava muito a nouvelle vague: o cara na moto, andando pela cidade com a câmera fixa nas costas. Agora me lembro do clima. Clima juvenil de uma garra fantástica, aqueles jovens desesperados para encontrar o caminho político, os desentendimentos, muito bonito". Quanto ao segundo filme, ele se recorda dos primeiros planos e do impacto causado nos realizadores do Cinema Novo carioca:

O túmulo do sol é mais bem realizado. Primeiros planos que pegavam a metade do rosto do favelado no sol, aquele solão [Em $70 \mathrm{~mm}$ ?] Puta! Aqueles primeiros planos! Esse filme todo mundo viu. Glauber viu, o Alex [Viany] viu e mudou o nome do filme que ele estava fazendo para Sol sob a lama (1963), por causa deste filme.

No entanto, o que João Batista de Andrade reconhece como influência do cinema japonês em seus próprios filmes é a violência presente nas relações, isto é, a explicitação e a exacerbação dos conflitos nas relações entre os personagens, a ruptura do diálogo. Essa é a razão de Andrade definir Doramundo (1977) e A próxima vítima (1983) como muito japoneses. A interpretação desses filmes pela chave das relações violentas suscita no pesquisador a lembrança de uma cena específica do filme de 1983, que é comentada pelo cineasta:

O cinema japonês é um cinema muito violento. Parece que passa uma violência sangüínea, uma necessidade de rompimento e de posições muito apaixonadas das pessoas. As pessoas tinham traços culturais e tradições e defendiam aquilo arraigadamente, viravam coisas vitais. Então o sujeito está acostumado a andar por um caminho e chega um outro dizendo que ele tem andar por outro, aquilo acaba virando um relacionamento violento. E isso é muito marcante, esta paixão. Porque, ao mesmo tempo em que você fala que é um 
comportamento tradicionalista, é uma paixão pela vida, pelas suas tradições e hábitos, por sua forma de ser, e isso era uma coisa impressionante para mim, era um lado positivo e problemático ao mesmo tempo. Então essa violência, o meu cinema tem muito disso. Talvez isso fique marcado. Você vai ver Doramundo e A próxima vítima, são filmes muito japoneses, são filmes muito duros. [A cena em que o ator Aldo Bueno mija em Antônio Fagundes em A próxima vítima.] Pois é, pois é! Essas coisas são levadas ao extremo, essa diferença de opinião, essa diferença de adesão à proposta da vida e tal, quando se encontram, os diálogos são difíceis, muitas vezes são violentos, são rupturas. Aquela seqüência é bem próxima deste tipo de violência do cinema japonês. [...] Essa radicalidade das reações entre personalidades, que cria essa violência, que você falou que está na seqüência de $A$ próxima vítima, aquilo não tem diálogo, não tem mediação.

Jean Claude Bernardet cita uma cena do filme A morte comanda o cangaço (1961, Carlos Coimbra e Walter Guimarães Motta), como um outro tipo de influência do cinema japonês no cinema paulista dos anos 1960. Aqui, ao contrário de relações globais, como "o feminino" ou "a violência" que caracterizam as conexões dos filmes de Reichenbach e Andrade com o cinema japonês, aponta-se para uma influência pontual, observada na composição de um determinado plano no filme de cangaço, como uma espécie de homenagem ou paráfrase de uma cena específica de um filme de samurai, formulada não pelos diretores do filme, mas por sua produtora, Aurora Duarte:

Aurora Duarte é uma produtora que produziu A morte comanda o cangaço, que foi um dos maiores sucessos de filmes de cangaceiro. Depois de $O$ cangaceiro (1963, Lima Barreto), da Vera Cruz, o cangaço meio que some e nos anos 1960 têm um grande ciclo de cangaço, alguns filmes com muita repercussão pública e A morte comanda o cangaço foi um deles. Na caatinga, tem um travelling que acompanha um cangaceiro ou um vaqueiro a cavalo, e entre a câmera e este vaqueiro tem uns arbustos secos, enfim, um longo travelling na catinga. Tempos depois ela me disse: "Isto é um movimento de câmera muito preciso", talvez do Kurosawa, mas ela disse que queria isto, que era de uma cena precisa de algum filme de samurai. Não era uma relação global do tipo, a violência ou o feminino. Não. Era uma coisa muito precisa que havia marcado ela. De Os sete samurais, uma coisa assim deste tipo. Isto eu tenho absoluta certeza dela ter falado isto.

E quanto ao filme A hora e a vez de Augusto Matraga, dirigido por Roberto Santos e que, conforme comentado, permaneceu em cartaz, em São Paulo, por apenas duas semanas? Qual é a relação entre esse filme, o cinema japonês e as salas da Liberdade? Sedi Hirano o associa aos filmes de samurai: "Eu tenho a impressão de que aquele filme sobre o Matraga, aquelas cenas de batalhas são cenas de batalhas de filmes de samurai. A seqüência final é muito bonita".

Carlos Reichenbach recorda-se de Roberto Santos ter assumido na época a influência de filmes de dois cineastas japoneses nessa adaptação cinematográfica do conto de Guimarães Rosa: Keisuke Kinoshita, o diretor de Murmúrios do rio Fuefuki, e Masaki Kobayashi, cineastas cujos filmes discutimos no capítulo anterior. O filme sobre Matraga foi rodado e 
finalizado em 1965, de modo que o filme de Kobayashi sobre samurai pode ser Harakiri (Seppuku, 1962) ${ }^{67}$, e o filme de Kinoshita, talvez, Shito no densetsu (Legend of a duel to the death, 1963):

Keisuke Kinoshita, de Murmúrios do rio Fuefuki, esse é um grande mestre, meu e do Roberto Santos. Keisuke Kinoshita? É um mestre! Kinoshita influenciou Roberto Santos para fazer A hora e a vez de Augusto Matraga. Esse filme é influenciado por dois filmes japoneses. Ele assumia isso. Um é o filme do Masaki Kobayashi, se não estou enganado Rebelião. A hora e a vez de Augusto Matraga, no final, vira um filme de samurai. Matraga mata o coronel Bem Bem com o golpe de lança. Tem dois filmes de dois diretores que o influenciaram, isso o Jairo Ferreira fala numa crítica. O Roberto Santos assumiu que o que influenciou A hora e a vez de Augusto Matraga foi um filme do Keisuke Kinoshita, e não Murmúrios do rio Fuefuki. É um outro filme de samurai, que eu não lembro o nome, e um filme do Masaki Kobayashi que, se eu não estou enganado, é Rebelião. Ele saiu torto do cinema, ele estava em vias de fazer o filme quando assistiu e, tem aquela coisa no final com a lança, quando ele mata o coronel Bem Bem, aquilo é filme de samurai! E tem uma hora que é genial, que é o momento mais bonito do filme, quando o covarde vira macho. $\mathrm{O}$ Matraga tem um empregado que é um cagão, medroso, mas quando tentam matar o Matraga ele vira macho, ele invade, sai matando três pela frente. Aquilo lá é Masaki Kobayashi. Pouca gente sabe, mas o próprio Roberto Santos assumia isso.

A relação de Roberto Santos com o cinema japonês e com as salas da Liberdade foi provocada pelo golpe militar de 31 de março de 1964, que implantou a ditadura militar no Brasil. De acordo com Inimá Simões (1997), o cineasta atuava há alguns anos em entidades de classe: inicialmente na Associação dos Técnicos e Artistas Cinematográficos do Estado de São Paulo, que, em julho de 1963, adquiriu o estatuto de Sindicato dos Trabalhadores na Indústria Cinematográfica de São Paulo, no qual Roberto ocupou a secretaria (Simões, 1997: 71).

A ditadura empreendeu a prisão de inúmeros sindicalistas e integrantes de setores que apoiavam publicamente o governo João Goulart e as reformas de base. As prisões atingiram diversos tipos de entidades, como sindicatos, universidades, redações de jornais, entidades estudantis e partidos políticos. O cenógrafo Cyro Del Nero escondeu Roberto Santos numa casa no bairro de Santana enquanto transportava Gianfrancesco Guarnieri e Juca de Oliveira de carro até o Mato Grosso (Idem, ibidem: 72). Após duas semanas de reclusão em Santana, o cineasta começa a circular pela cidade à procura de notícias dos conhecidos. As insuspeitas sessões de filmes japoneses na Liberdade constituiriam mais do que um abrigo para um refugiado:

[...] Atrás de uma cortina, conferindo alguma presença suspeita na calçada, Roberto ficou uns quinze dias no discreto esconderijo arrumado por Cyro Del Nero mas com o tempo aumentava a angústia e a curiosidade de saber o que estava acontecendo com as pessoas.

\footnotetext{
${ }^{67} \mathrm{O}$ filme citado por Reichenbach, Rebelião (Samurai rebelion), dirigido por Masaki Kobayashi, foi produzido
} em 1967. 
Sem suportar mais a reclusão, começou a circular discretamente pela cidade com o amigo Norberto Nath, evitando os pontos de encontro tradicionais para avaliar o quadro geral. As notícias colhidas eram as mais desencontradas, e os amigos estavam quase todos sumidos. Ouvia-se falar em prisões, gente sendo vigiada, mas como conferir? Restava o programa insuspeito de assistir filmes nipônicos no bairro da Liberdade, nas mormacentas sessões vespertinas, porque ninguém imaginava encontrá-lo ali. Quando Matraga estreou na cidade em março de 1966, alguns críticos perceberam claras influências do cinema japonês em algumas passagens do filme. Resultado possível de seu estágio naquelas sessões... (Simões, 1997: 73).

Ao longo das quatro partes que formam a seção "O público não-nikkei" deste capítulo, assim como em outras seções dos capítulos relacionados às salas da Liberdade e aos filmes japoneses em São Paulo, pretendeu-se enfatizar, por um lado, que, assim como no caso do público japonês e nikkei dos cinemas da Liberdade, os freqüentadores não-nikkeis dessas salas não constituíram um grupo único e homogêneo, mas ao contrário, havia diferenças entre eles de várias naturezas - de preferências estéticas, de posturas ideológicas, de interesses, de geração, de grupos ou turmas de amigos, de ocupação, de envolvimento com a cultura japonesa, entre tantas outras. Essas diferenças também iam de pequenas divergências estéticas ou intelectuais à explicitação pública do conflito, como na violência japonesa dos filmes de João Batista de Andrade.

Por outro lado, tentou-se demonstrar que, junto a essa diversidade do público nãonikkei, havia uma outra, a diversidade dos filmes japoneses exibidos em São Paulo, decorrente do expressivo contingente de japoneses e nikkeis residentes no estado, e da maneira pela qual as sessões de cinema japonês tornaram-se uma prática cultural central para eles. Com relação ao público não-nikkei, a hipótese que se pretendeu comprovar é a de que a oferta de cinema japonês na cidade de São Paulo era tão variada, comportando uma tal diversidade de gêneros, estilos, modos de produção (dos grandes estúdios, de estúdios independentes), linguagens, valores, públicos-alvos, proposições estéticas e políticas, gerações de realizadores, que as diferenças entre os grupos de freqüentadores não-nikkeis, muitas delas anteriores ou exteriores ao cinema japonês, encontravam rebatimento nas diferenças entre os filmes japoneses exibidos nos cinemas da Liberdade. Em outras palavras, a diversidade do cinema japonês que chegava a São Paulo era tão maior do que a dos demais centros cinematográficos ocidentais que grupos diversos de cinéfilos encontraram expressões diversas nos filmes japoneses. Jean Claude Bernardet interpreta essa hipótese:

É claro que estávamos vivendo num momento numa sociedade muito politizada, ou, pelo menos, numa camada da sociedade brasileira e paulista muito politizada, e que, portanto, houve opções cinematográficas, inclusive opções cinematográficas japonesas, em função de opções ideológicas, políticas etc. Por outro lado, o cinema japonês [entre aspas] pode ter 
reforçado determinadas tendências. Porque necessariamente é errado dizer que o cinema japonês tenha criado estas diferenças ou que o cinema japonês não tinha nada a ver com elas. Quer dizer, na realidade são tecidos muito imbricados. É uma coisa que é marcante pelo que você está dizendo, que pegando pessoas como Reichenbach, Parolini, o João Batista, o Khouri etc. é uma grande diversidade: de posturas, de gostos, de opções políticas, de direcionamento ideológico, uma grande diversidade. E por outro lado, que essa fartura de cinema japonês que existia aqui, que não existia em outros lugares, e isso se deve muito à colônia, era de uma imensa riqueza, que possibilitou que a diversidade cultural, ideológica, política, estética dessa juventude, enfim, dessas pessoas que estavam começando as suas carreiras cinematográficas encontrarem uma variedade dentro do que chegava do Japão. Isto é admirável! Por isso que eu te digo, agora pouco, o cinema japonês entre aspas, porque o cinema japonês é uma variedade. [Cinemas japoneses] Cinemas japoneses, sim. E, naturalmente, grupos diversos encontraram expressões diversas nos filmes japoneses. 


\section{Considerações finais}

Olga Futemma comenta o texto de João Antônio, em que ele afirma ter sentido preconceito racial nas salas de cinema da Liberdade, no início dos anos 1950. Mas em sua reflexão, a questão do preconceito é deslocada para uma diferenciação estabelecida entre os japoneses e seus descendentes, relacionada à região de origem dos imigrantes: o preconceito dos japoneses em relação aos okinawanos. Ela narra alguns episódios vividos na infância, tanto com famílias japonesas de colegas da escola, quanto em sua própria, na qual era orientada a comportar-se como uma "japonesa". Essas experiências pessoais são relacionadas por ela à dinâmica das relações entre japoneses e okinawanos, desde a chegada do navio com os primeiros imigrantes japoneses ao Brasil, em 1908:

É, anos 1950 eu acho que havia preconceito mesmo, eu acho que por parte da colônia como um todo. Essa questão do preconceito eu acho muito complicada, todo preconceito gera um contra-preconceito e assim vai. Eu acho que eu senti um pouco isso quando eu era muito okinawana. Eu tinha amigas japonesas na escola, porque primeiro você se aproxima do que você acha que é seu igual, não é isso? Tinha as meninas japonesas, mas, invariavelmente, toda a vez que eu ia na casa de alguma delas, a mãe, a tia ou a avó me perguntavam o nome e eu falava: - Futemma. - Ah! Okinawa? - e aquilo ficava na minha cabeça porque eu não me sentia absolutamente diferente das outras. Havia também um certo cuidado na minha casa: - Cuidado quando for falar o japonês! Não vai se atrapalhar e falar termos okinawanos! - Mas qual o problema de falar que isso é não sei o que? - Ah, não pode. Então, sub-repticiamente, nós éramos orientados a nos comportar como japoneses. Para mim era um mistério isso. E ficava mais esquisito, porque eu percebia que para os brasileiros era tudo igual. [...] Mas você vai trabalhando isso, e percebendo esse olhar diferente do próprio japonês em relação a você, você percebe que tem também uma reação dos okinawanos em relação a isso. Quarenta por cento dos imigrantes do Kasato Maru vieram de Okinawa. Houve um movimento de interromper a imigração okinawana para o Brasil. Os japoneses estavam muito bronqueados porque os okinawanos não tinham jeito, andavam descalços, carregavam os filhos nas costas, qualquer coisa era motivo para dançar e cantar e fazer barulho, que gente mais indisciplinada! Era essa a imagem do okinawano.

Como visto no capítulo anterior, para exemplificar os preconceitos existentes contra os japoneses e nikkeis no Brasil na década de 1940, Sedi Hirano citou a pesquisa na qual apenas cinco por cento das estudantes normalistas aceitavam o japonês como membro da família. Com isso ele afirma a existência de um preconceito recíproco entre nikkeis e não-nikkeis, relativizando a explicação, corrente na época, que atribuía a baixa ocorrência de relações interétnicas aos padrões culturais tradicionais dos japoneses, como a organização familiar, o casamento como arranjo entre famílias e a autoridade paterna. Hirano relaciona os dados da pesquisa de 1940 com a sua experiência pessoal, vivida mais de vinte anos depois, durante o curso de ciências sociais da Faculdade de Filosofia, Letras e Ciências da Universidade de São Paulo: 
Eu sei que eu namorei moças de famílias tradicionais, que eram colegas da universidade. $\mathrm{O}$ problema que as moças de família tradicional tinham ao namorar um nissei, um nãodescendente de europeus, era uma questão muito forte. É possível até ter documentos sobre essas questões todas. Uma filha de uma família quatrocentona, que freqüenta as melhores casas paulistanas, andando com um descendente de japoneses... Deve ser coisa complicada também para o outro lado. Mas isso era na década de 1960. O nissei quando casava [casamentos interétnicos], sempre casava com uma pessoa de estrato um pouco mais baixo, isso muitas vezes ocorria.

Eunice Yokota, que também fez o curso de ciências sociais da Faculdade de Filosofia na mesma época que Hirano, porém à tarde, lembra que a maior parte de seus colegas eram de famílias paulistanas tradicionais ou poderosas, incluindo filhos de catedráticos, de ministros de estado e de arquitetos famosos. Ela comenta que na época só havia uma colega nikkei, vinda da cidade de Tupã. O ambiente das classes é caracterizado como estranho, porque ao contrário dela e da colega de Tupã que, como filhas de imigrantes eram ingênuas e não sabiam ao certo porque faziam o curso, seus colegas eram pessoas intelectualizadas, politizadas e sabiam muito bem porque estavam lá. Para ela, a principal contribuição da faculdade foi a abertura de horizontes provocada pela interação com pessoas desse outro mundo, definidas por ela como abertas:

Então, eram pessoas que tinham um background totalmente diferente de uma filha de imigrante. Então isso foi muito rico para a gente, para mim, no caso, porque eu vi um outro mundo, que eu nunca tinha entrado, que eu não participava e que nem sabia que existia. Então, foi uma abertura de horizontes incrível, quer dizer, o curso não foi importante pelo que ele ensinou, mas pelo que eu vivenciei das pessoas, e as pessoas eram muito abertas, apesar de serem da elite paulistana.

Há, evidentemente, uma diferença entre a aceitação de um nikkei no círculo social de uma família tradicional e a aceitação dele como um membro dessa família. Entretanto, nos anos 1960, essas barreiras não se expressavam apenas nas famílias da elite paulistana. Cláudio Willer, que como vimos no segundo capítulo, aproximou-se do cinema japonês na época do cursinho, relembra de um episódio, em meados dos anos 1960, em que caminhar com uma namorada nikkei na rua Galvão Bueno provocou, além de estranheza, contrariedade por parte da colônia japonesa local, sendo encarado como uma provocação. Traçando paralelos com resistências percebidas em outras relações inter-étnicas, Willer atribui isso não ao preconceito, mas ao fato da sociedade ser mais fechada na época:

Naquela época, 1964, justamente, eu tive uma namoradinha japonesa. Era algo que não existia. Nas vezes em que eu passeei com ela na Galvão Bueno, foi [visto como] provocação, o pessoal olhava. A colônia japonesa não gostava disso nem um pouco. Seria mais ou menos como, digamos, um judeu, de uma família judaica praticante, namorar uma 
goen, uma não-judia. Eram culturas mais fechadas. [Isso indica que havia preconceito recíproco na época?] Eu não acho que seja preconceito. Acho que é uma questão de preservação. As culturas se fecham para preservar a identidade, quer dizer, o ocidental era um estranho para o japonês, com o qual tinham relações muito cordiais. É claro que nos restaurantes e em todos os lugares nos éramos muito bem recebidos, mas havia aquela coisa de eles serem eles. [...] E a mocinha, a namorada, me deixou bem claro que realmente eu estava provocando estranheza. Bom, naquela época se eu saísse com uma negra, tipo namorar, socialmente e tal, com certeza causaria estranheza também. Quer dizer, era uma sociedade mais fechada no geral.

Preconceitos e barreiras entre nikkeis e não-nikkeis existiram também em relação aos filmes japoneses. Ricardo Gonçalves relembra de um episódio com um filme que o marcou fortemente, Tokyo no hito sayonara (1956), uma história de amor com fim trágico, do qual um crítico de cinema escreveu tratar-se de uma comédia sem sentido, que só poderia interessar ou ser entendida pelo público japonês. A experiência de Gonçalves com o filme, no entanto, por mais orientalizado que ele fosse, contradiz essa barreira cultural ou cognitiva do filme para o público não-nikkei:

Tinha alguns filmes que passaram despercebidos do público brasileiro, mas eu me lembro de um filme estrelado pela cantora Shimakura Chiyoko, era um romance de amor de uma camponesa, que vivia em Oshima, uma ilha perto de Tóquio, e aparecia ali um rapaz que vinha de Tóquio a serviço da firma, passava por lá e voltava. Era a história de um amor proibida, trágica, que terminava em separação. $O$ filme era muito bonito por causa das paisagens da ilha de Oshima e das canções da Shimakura Chiyoko, então esse filme também me marcou muito. Era um filme que alguém escreveu no Estado de S. Paulo: - Ah, isso é o tipo de filme japonês que não interessa. Só os japoneses entendem, para nós, brasileiros, este tipo de filme é um mistério, não nos diz nada. Mas, ao contrário, foi um filme que me tocou bastante. $\mathrm{O}$ que eu achei engraçado é que a pessoa que escreveu o texto comparou o filme às comédias italianas. Ele dizia: - Nós estamos acostumados com a comédia italiana, com o Walter Chiari, com o Ugo Tognazzi, comédia japonesa a gente não entende - só que não era comédia coisa nenhuma, era um romance trágico até porque terminava em separação. [Ele coloca uma espécie de barreira cultural aos não-nikkeis, que não foi a sua experiência.] Não, não tive essa experiência. E gozado que o pessoal do escritório da Toho também tinha essa barreira. Então ele dizia: - Tem filmes nossos aqui que a gente pode passar para gaijin, que eles entendem, agora tem outro tipo de filme que não adianta passar para gaijin que eles jamais vão entender, isso é só para nós, é só para japonês. Quer dizer, a gente legendava direitinho, mas o próprio escritório já partia desse preconceito: - Esse filme só japonês que vai entender, gaijin não vai entender nada ${ }^{68}$.

Outras barreiras e preconceitos eram, assim, postulados por parte dos funcionários japoneses do escritório da Toho em São Paulo em relação ao público não-nikkei, ou, como eles mesmos se referiam, ao público gaijin. Donald Richie, ao comentar sobre o choque causado no Japão com a conquista do prêmio de cinema mais conceituado da época por Rashomon,

\footnotetext{
${ }^{68}$ A tradução de gaijin é estrangeiro. Esse termo era usado pelos japoneses e descendentes no Brasil para se referirem aos não-nikkeis. Nihonjin, ao contrário, designa japonês.
} 
cujas interpretações vimos no primeiro capítulo, atribuiu como primeira causa da surpresa o fato de que o filme não havia sido feito para exportação: “[...] e aqui se registra um insistente preconceito japonês de que coisas não feitas especialmente para estrangeiros não serão compreendidas por eles" (Richie, [1965] 1984: 79). A frase do funcionário da Toho no Brasil parece se relacionar com o preconceito citado.

Gonçalves descreve a visão dos representantes dessa companhia sobre os tipos de filmes correspondentes ao gosto de cada público. Mas a crescente apreciação dos filmes intimistas por parte do público não-nikkei brasileiro nos anos 1950, e também pela crítica de cinema francesa, anos depois, evidencia a superação de alguns desses preconceitos e barreiras:

De maneira geral, eles gostavam muito de fazer publicidade de filme de samurai pelo exotismo: - Ah, brasileiro gosta de ver samurai porque é uma cultura diferente, uma cultura exótica. [...] E filmes de ação, de época e de yakuza. Agora, tinha muitos dramas intimistas, tinha diretores especializados em descrever as minúcias da psicologia feminina, dramas de amor, coisas assim, sobre os quais eles geralmente diziam: - Não, esse filme aí não vai interessar aos gaijin, isso é só para nihonjin. Naruse Mikio era um dos grandes diretores nessa linha, além de Ohba e Gosho. Agora alguns destes filmes começaram a fascinar os brasileiros, mas na visão do escritório isso não era filme para gaijin.

Hannerz (1997) reflete sobre os processos culturais em contextos globais ou transnacionais, os novos focos da pesquisa antropológica a partir da década de 1990, chamando a atenção para o caráter polimorfo adquirido pelos fluxos culturais através das distâncias:

Na medida em que a cultura se move por entre correntes mais específicas, como o fluxo migratório, o fluxo de mercadorias e o fluxo da mídia, ou combinações entre estes, introduzse toda uma gama de modalidades perceptivas e comunicativas que diferem muito na maneira de fixar seus próprios limites; ou seja, em suas distribuições descontínuas entre pessoas e relações (idem, 1997: 18).

Hannerz argumenta que, se por um lado esses fluxos impõem uma língua, na medida em que a mera exposição não é o mesmo que compreender, valorizar ou qualquer outro tipo de apropriação, por vezes um gesto, uma música, [ou um filme], podem ser imediatamente compreendidos num país estrangeiro, de modo que uma distribuição é modificada e um limite é transcendido com rapidez e facilidade.

Não estaria o cinema japonês exibido nas salas da Liberdade justamente numa combinação de correntes, isto é, entre o fluxo migratório, o fluxo de mercadorias e o fluxo da mídia? A modificação de uma distribuição ou transcendência de um limite talvez explique o porque daquelas salas de cinema terem conquistado outros públicos, além daquele 
inicialmente esperado, e também a diversidade dos "cinemas japoneses" apreciados pelos espectadores não-nikkeis paulistanos.

Appadurai $(1997,2005)$ apresenta o conceito de produção de localidades a partir de três diferentes definições: "mundos de vida" constituídos por associações relativamente estáveis, histórias compartilhadas e lugares coletivamente ocupados; a memória e a ligação dos sujeitos locais com suas ruas e cenários urbanos preferidos, os momentos e lugares para congregação e divertimento; e por fim, como as estruturas de sentimento que permeiam a imaginação da comunidade.

Alguns aspectos destacados pela definição, como as histórias compartilhadas, os locais e momentos de encontro e diversão, ou as estruturas de sentimento formadoras do imaginário local, parecem ser descrições pertinentes para as experiências relacionada ao cinema japonês na Liberdade. Nesse conceito, a palavra produção enfatiza o caráter processual ou formativo da localidade, e formação, empregada aqui em diferentes sentidos, parece ter sido um aspecto central dessas experiências:

A formação, ou recomposição, do bairro japonês em torno das salas de cinema e do fluxo de pessoas que para elas convergiam, fazendo movimentar o comércio do bairro. $\mathrm{O}$ desenvolvimento da Liberdade não apenas como um centro de comércio de produtos japoneses, mas como um local de encontro em torno de atividades de cultura e lazer, como os cinemas, os nodojiman [concursos de canto], os bailes nikkeis, as sessões de meditação nos templos budistas, os cursos de japonês e ikebana na Aliança Cultural Brasil-Japão, além dos restaurantes e bares japoneses.

E formação também como um processo educativo, vivido de forma prazerosa, por se tratar de uma atividade livre ou optativa. Uma educação processada essencialmente por meio das emoções e que contribuiu para a estruturação de sentimentos no imaginário local, como, por exemplo, através dos efeitos catárticos propiciados pelas sessões de filmes japoneses no pós-guerra, ou pela contribuição dessas sessões para a reconciliação dos japoneses e nikkeis após os conflitos opondo os kachigumi e os makegumi.

Emoções e sentimentos elaborados nos filmes japoneses e que adquiriram no Brasil significados locais múltiplos, aqui sintetizados: para alguns japoneses, o reconhecimento da situação do Japão no pós-guerra e a atualização das imagens sobre o país; no caso dos nikkeis, o aprendizado de aspectos da sociedade e da cultura japonesas, como a língua, padrões de 
comportamento e valores, relacionados, de diferentes modos, às suas histórias familiares; e para os espectadores não-nikkeis, especialmente para aqueles que viriam a se tornar importantes críticos e cineastas paulistas, a influência dos filmes japoneses assistidos nos anos de formação, e que repercutiram na reflexão sobre o cinema e em filmes realizados a partir da década de 1960. 


\section{Referências bibliográficas}

ALMEIDA, Heloisa Buarque. Cinema em São Paulo - hábitos e representações do público (anos 40/50 e 90). Dissertação de mestrado - Faculdade de Filosofia, Letras e Ciências Humanas, Universidade de São Paulo, 1995.

. "Janela para o mundo: Representações do público sobre o circuito de cinema de São Paulo". In: MAGNANI J. G. C.; TORRES, L.L. (Orgs.). Na Metrópole. Textos de antropologia urbana. São Paulo: Edusp/Fapesp, 1996, p. 156-195.

. "Quando o Metro era um palácio: salas de cinema e modernização em São Paulo" Cadernos de Campo. São Paulo: USP, 5 e 6, 1997, p. 87-116.

Telenovela, consumo e gênero. “Muito mais coisas”. Bauru: Edusc, 2003.

ALMEIDA SALLES, Francisco Luiz. “Os Sete Samurais”. In: BENDER, F. C.; LAURITO, Ilka Brunhilde. (Orgs.) Cinema e verdade. Francisco Luiz de Almeida Salles. São Paulo: Companhia das Letras e Cinemateca Brasileira, 1988, p. 183-185.

ANTONIO, João. "Vibrações, pulgueiros e 'Ladrões de bicicletas"”. Filme Cultura. Rio de Janeiro: Embrafilme, 47, 1986, p. 74-78.

APPADURAI, Arjun. "Soberania sem territorialidade - Notas para uma geografia pósnacional". Novos Estudos Cebrap. São Paulo: Cebrap, 49, 1997, p. 7-32.

. "Here and now". "The production of locality". In: Modernity at large. Cultural dimensions of globalization. Minneapolis: University of Minnesota Press, [1996] 2005, p. 123 e 178-199.

ARAÚJO, Inácio. "O cineasta japonês participou de palestra na Fundação Japão com Walter Hugo Khouri e Ismail Xavier”. In: Folha de São Paulo, São Paulo, 10/09/1995.

ARAÚJO, Vicente de Paula. Salóes, circos e cinemas de São Paulo. São Paulo: Editora Perspectiva, 1981.

ARISTÓTELES. Poética. São Paulo: Ars Poetica, 1993.

BENEDICT, Ruth. O crisântemo e a espada. São Paulo: Editora Perspectiva, 1998.

BERNARDET, Jean Claude. Historiografia clássica do cinema brasileiro: metodologia e pedagogia. São Paulo: Annablume, 1995.

In: ROCHA, Glauber. Cartas ao mundo. São Paulo: Companhia das Letras, 1997.

BIÁFORA, Rubem. “Mar de Rosas” (24/07/1978), “Doramundo” (19/11/1978), “Kagemusha, a sombra do samurai" (24/05/1981), "Entrevista". In: MOTTA, Carlos M. (Org.). Críticas de 
Rubem Biáfora. A coragem de ser. São Paulo: Imprensa Oficial, 2006, p. 35-37, 40-42, 128129, 179-186.

"É triste ser homem $23^{a}$ época" (01/11/1981), In: O Estado de S. Paulo. São

Paulo: $O$ Estado de $S$. Paulo apud Indicações do Biáfora [http://indicacaorubembiafora.blogspot.com].

BOCK, Audie. "Masaki Kobayashi". In: Japanese film directors. Tóquio: Kodansha International, 1980, p. 245-264.

BOSI, Ecléa. "A pesquisa em memória social". Revista do Instituto de Psicologia. São Paulo: USP, 1993, v. 4, 1 e 2, p. 277-284.

Memória e sociedade: lembranças de velhos. São Paulo, Companhia das

Letras, 1994.

O tempo vivo da memória. São Paulo, Ateliê Editora, 2004.

CAIUBY NOVAES, Sylvia. "Introdução". In: Jogo de espelhos: imagens da representação de si através dos outros. São Paulo: Edusp, 1993, p. 21-33.

• "O Uso da Imagem na Antropologia”. In: SAMAIN, Etienne (Org.). $O$ Fotográfico. São Paulo: Hucitec e SENAC, 2005, p. 107-115.

CIOCHETI, Ermetes e outros. O filme japonês. São Paulo: Grupo de Estudos Fílmicos, 1963.

CYTRYNOWICZ, Roney. "Introdução", "O “Pão de Guerra” e o Fator Dieta”, “Os caracteres japoneses" "A cidade apagada de Tomoo Handa". In: Guerra sem guerra: a mobilização e o cotidiano em São Paulo durante a Segunda Guerra Mundial. São Paulo: Geração Editorial/Editora da Universidade de São Paulo, 2000, p. 13-39, 51-66, 135-172, 173-178.

CUNHA, Manuela Carneiro. "Etnicidade: da cultura residual mas irredutível". In Antropologia do Brasil: mito, história e etnicidade. São Paulo, Brasilense: Edusp, 1986, p. 97-108.

DAWSEY, John C. "Victor Turner e a antropologia da experiência". In: Cadernos de Campo. São Paulo: USP-FFLCH, 2005, 13, p. 163-176.

. "Por uma antropologia benjaminiana: repensando paradigmas do teatro dramático". São Paulo, FFLCH-USP, 2009.

FERREIRA, Jairo. "Ishihara e a juventude" (19/1/1967). "Samurais, 008, fatalismo" (17/08/1967). In: GAMO, Alessandro (Org.). Jairo Ferreira e convidados especiais - Críticas de invenção: os anos do São Paulo Shimbun. São Paulo: Imprensa Oficial do Estado de São Paulo/ Fundação Padre Anchieta, 2006, p. 33-35, 44-46.

“Jairo Ferreira - síntese ideogrâmica". In: Cinema de invenção. São Paulo: Limiar, 2000, p. 123-135. 
. "O iconoclasta Eizo Sugawa”. In: Folha de S. Paulo, São Paulo, 21/12/1986

apud Cinema de invenção - Textos de Jairo Ferreira [blog: http://cinema-deinvencao.blogspot.com/2007/07/o-iconoclasta-eizo-sugawa.html]

FRÚGOLI Jr., Heitor. Sociabilidade urbana. Rio de Janeiro: Jorge Zahar Ed., 2007.

FUTEMMA, Olga. “As salas japonesas no bairro da Liberdade”. Revista Filme Cultura. Rio de Janeiro: Embrafilme, 1986, 47, p. 79-81.

GAMO, Alessandro. Vozes da Boca. Tese de doutorado - Instituto de Artes da Universidade Estadual de Campinas. Campinas, 2006.

GATTI, André. "Cultura, identidade e diversidade cinematográficas: o caso São Paulo, o cinema japonês e as suas salas de exibição". FACOM. São Paulo: FACOM/FAAP, 2008, nº 19 , p. $30-41$.

GEERTZ, Clifford. A Interpretação das culturas. Rio de Janeiro: Guanabara Koogan, 1989.

GOMES, Paulo Emílio Sales. "Singularidade do Japão" (03/08/1957). “Atualidade Japonesa" (10/08/1957). "Três mestres japoneses" (17/08/1957). In: Crítica de cinema no suplemento literário, v. 1. Rio de Janeiro, Paz e Terra/Embrafilme, 1981, p. 171-183.

GRUPO DE ESTUDOS FÍLMICOS. O filme japonês. São Paulo: Ed. Revista Matemática, 1963.

GUPTA, A. \& FERGUSON, J. "Mais além da 'cultura': espaço, identidade e política da diferença" [1992]. In: ARANTES, A. A. (org.). Espaço da diferença. Campinas: Ed. Unicamp, 2000, p. 31-49.

HALBWACHS, Maurice. A memória coletiva. São Paulo, Vértice, Editora Revista dos Tribunais, 1990 .

HANDA, Tomoo. O imigrante japonês - História de sua vida no Brasil. São Paulo: T. A. Queiroz: Centro de estudos Nipo-Brasileiros, 1987.

HANNERZ, Ulf. "Fluxos, fornteiras, híbridos: palavras-chave da antropologia transnacional". Mana: estudos de antropologia social. Rio de Janeiro, 1997, 3 (1), p. 7-39.

HIKIJI, Rose Satiko Gitirana. Imagem-violência: Mímesis e reflexividade em alguns filmes recentes. Dissertação de mestrado - Faculdade de Filosofia, Letras e Ciências Humanas-USP, 1998a.

- "Antropólogos vão ao cinema - observações sobre a constituição do filme como campo". Cadernos de Campo. São Paulo, 1998b, 7, FFLCH-USP, p. 91 a 113.

HIRATA, Kimayasu. "Roho, Nippaku Shinema sha”. In: Coronia Gueinoshi [História da Arte da Colônia]. São Paulo: Sociedade Brasileira de Cultura Japonesa, 1986, p. 217-230. 
HOSOKAWA, Shuhei. “A história da música entre os nikkei no Brasil - enfocando as melodias japonesas". In: Anais do IV Encontro Nacional de Professores Universitários de Língua, Literatura e Cultura Japonesa. São Paulo: Centro de Estudos Japoneses da Universidade de São Paulo, 1993, p. 125-147.

. Cinemaya Burajiru wo iku [O cinema japonês vai ao Brasil]. Tóquio: Shinchosha, 1998.

JOSEPH, Isaac. "A respeito do bom uso da Escola de Chicago". In: VALLADARES, L. P. (org.). A Escola de Chicago: impactos de uma tradição no Brasil e na França. Belo Horizonte e Rio de Janeiro: Ed. UFMG/IUPERJ, 2005 [1998], p. 91-128.

KHOURI, Walter Hugo. "Influências do cinema japonês na concepção cinematográfica de diretores brasileiros”. In: ABE OI, Célia (org.). Cultura Japonesa. São Paulo: Fundação Japão/Aliança Cultural Brasil-Japão, [1994] 1997, p. 138-141.

KOBAYASHI, Eliza Mayumi. O herói do Japão. História(s) do Cine Niterói. Trabalho de Conclusão de Curso - Escola de Comunicações e Artes, Universidade de São Paulo, 2005.

KOBORI, Edna. "O cinema japonês em São Paulo" In: ABE OI, Célia (org.). Cultura Japonesa. São Paulo: Fundação Japão/Aliança Cultural Brasil-Japão, 1997, p. 142-147.

KUMASAKA, Y. \& SAITO, H. "Kachigumi: uma delusão coletiva entre os japoneses e seus descendentes no Brasil". In: SATO, Hiroshi; MAEYAMA, Takashi. Assimilação e integração dos japoneses no Brasil. São Paulo: Edusp, 1973, p. 448-464.

LESSER, Jeffrey. "O hífen oculto". "Em busca de um hífen". "Negociações e novas identidades". In: A negociação da identidade nacional: imigrantes, minorias e a luta pela etnicidade no Brasil. São Paulo: Editora Unesp, 2001, p. 17-36, 87-152, 153-210.

. "Os limites da flexibilidade", "A orla do Pacífico e o mundo atlântico", “O Japão do Brasil", "Belos corpos e identidades desaparecidas". In: Uma diáspora descontente: os nipo-brasileiros e os significados da militância étnica (1960-1980). São Paulo: Paz e Terra, 2007, p. 21-34, 35-62, 63-86, 87-116.

LYRA, Marcelo. Carlos Reichenbach. O cinema como razão de viver. São Paulo: Imprensa Oficial do Estado de São Paulo, 2004.

MANEKAR, Purnima. "Epic Contents. Television and Religious Identity in Índia”. In: Media Works. Califórnia: University of Califórnia Press, 2002, p. 134-151.

MARQUES DE OLIVEIRA, José Eduardo. "Tadashi Imai”. In: O filme japonês. São Paulo: Grupo de Estudos Fílmicos, 1963, p. 46-48. In: OHNO, Masao. Cinema Japonês. São Paulo, Cinemateca Brasileira, 1964. 
McDONALD, Keiko. “Japan”. In: LENT, John A.. The Asian Film Industry. Texas: First University of Texas Edition, 1990, p. 34-60.

MIZUMOTO, Tsuyoshi. "Shochiku (Narayama Bushi-ko) de Shinshyutsu" e "Sempai no guiyoseki ni keii”. In: Coronia Gueinoshi [História da Arte da Colônia]. São Paulo: Sociedade Brasileira de Cultura Japonesa, 1986, p. 255-258 e 271-272.

MORIBE, Patrícia. Nas telas da Liberdade: dos grandes clássicos ao trash. Trabalho de Conclusão de Curso - Escola de Comunicações e Artes, Universidade de São Paulo, 1991.

MORIN, Edgar. Cultura de massa no século XX - O espírito do tempo - 1 - Neurose. Rio de Janeiro: Forense-Universitária, 1984.

MOTTA, Carlos M. (org.). Críticas de Rubem Biáfora. A coragem de ser. São Paulo: Imprensa Oficial do Estado de São Paulo, 2006.

NAGIB, Lúcia. Em torno da nouvelle vague japonesa. Campinas: Editora da Unicamp, 1993. Nascido das cinzas: Autor e sujeito nos filmes de Oshima. São Paulo: Editora da Universidade de São Paulo, 1995.

. "A cinelândia da Liberdade". In: Fundação Japão/Assessoria Cultural do Consulado Geral do Japão. Guia da Cultura Japonesa. São Paulo: Editora JBC, 2004.

. “Towards a positive definition of World Cinema". In: LIM, Song Hwee e DENNISON, Stephanie (orgs.). Remapping World Cinema: Identity, Culture and Politics in Film. Londres: Wallflower Press, 2005, p. 30-37.

NEGAWA, Sachio. Formação e transformação do bairro oriental. Um aspecto da história da imigração asiática da cidade de São Paulo, 1915-2000. Dissertação de mestrado - Faculdade de Filosofia, Letras e Ciências Humanas-USP, São Paulo, 2000.

. "Um comerciante japonês: história de vida no bairro oriental de São Paulo". Estudos Japoneses. São Paulo: USP, 2001, 21, p. 101-114.

NOVIELLI, Maria Roberta. História do cinema japonês. Brasília: Editora UnB, 2007 [2001]. OHNO, Massao. Cinema Japonês. São Paulo: Massao Ohno Editora/Cinemateca Brasileira, 1964.

OSHIDA, Masao. “Toho ga guiyokai ni shimpu 'shinfuu””. In: Coronia Gueinoshi [História da Arte da Colônia]. São Paulo: Sociedade Brasileira de Cultura Japonesa, 1986, pp. 237-245. PAROLINI, Orlando. "Sugawa Eizo". In: O filme japonês. São Paulo: Grupo de Estudos Fílmicos, 1963, p. 95-98.

RAMOS, Paulo Roberto. Amarcord: lembranças de filmes, salas e caminhos de cinema. Tese de doutorado - Instituto de Psicologia, Universidade de São Paulo, 2008. 
REICHAUER, Edwin O. "Introdução”. In: YOSHIKAWA, Eiji. Musashi. São Paulo: Estação Liberdade, 1999, p. 11-16.

RIBEIRO, João. "Hiroshi Inagaki" In: O filme japonês. São Paulo: Grupo de Estudos Fílmicos, 1963, p. 37-39.

RICHIE, Donald \& ANDERSON, Joseph L. The Japanese Film: Art and Industry. Tóquio: Charles F. Tuttle Company, 1959.

RICHIE, Donald. Japanese Cinema: Film Style and National Character. Nova Iorque: Doubleday, 1971.

. Os filmes de Akira Kurosawa. São Paulo: Brasiliense, [1965] 1984.

. “A mão do passado". In: Japão, a história através do cinema. Lisboa:

Cinemateca Portuguesa, 1982, pp. 5-6.

A hundred years of Japanese film. Tóquio: Kodansha Internacional, [2001]

2005.

. “Cinema Japonês: Um Olhar Pessoal (1947-1995)". Imagens. Campinas:

Editora da Unicamp, 1996, 7, p. 62-77.

RICOEUR, Paul. "O tecer da intriga: uma leitura da Poética de Aristóteles". Tempo e Narrativa. Tomo 1. Campinas: Papirus Editora, 1994, p. 55-84.

RODRIGUES, José Fioroni. "Panorama geral do cinema japonês e sua época de ouro". Revista USP. São Paulo: CCS-USP, 1995, 27[Dossiê Brasil-Japão], p. 165-169.

SAHLINS, Marshall. "O "Pessimismo sentimental" e a experiência etnográfica: porque a cultura não é um "objeto" em via de extinção". Parte I. Mana: estudos de antropologia social. Rio de Janeiro, 1997, 3(1), p. 41-73.

. "O "Pessimismo sentimental" e a experiência etnográfica: porque a cultura não é um "objeto" em via de extinção". Mana: estudos de antropologia social. Rio de Janeiro, 1997, pp. 103-150.

SATO, Tadao. "Kurama Tengu and Kurama Tengu Kyofu Jidai (The Frightful Era of Kuramu Tengu)". Tokyo, s/d.

. "Características do filme histórico japonês". In: Japão, a história através do cinema. Lisboa: Cinemateca Portuguesa, 1982, p. 3-4.

SCHATZ, Thomas. "Introdução: A equação completa do cinema" e "Warner Bors.: A guerra dentro e fora dos Estados Unidos”. In: O gênio do sistema. A era dos estúdios em Hollywood. São Paulo: Companhia das Letras, 1991, p. 17-26 e 303-326.

SILVA, Ermínia. Circo-teatro. Benjamim de Oliveira e a teatralidade circense no Brasil. São Paulo: Altana, 2007. 
SILVER, Alain. The Samurai Film. Woodstock: Overlook Press, 1983.

SIMÕES, Inimá. As salas de cinema em São Paulo. São Paulo: Divisão de pesquisa - CCSPSMC, 1982.

. “Anos 50: em São Paulo, a Cinelândia dá o tom”. In: Filme e Cultura. Rio de Janeiro: Embrafilme, 1986, 47, p. 62-73.

. Roberto Santos: a hora e a vez de um cineasta. São Paulo: Estação Liberdade, 1997.

SIMMEL, Georg. "A sociabilidade (Exemplo de sociologia pura ou formal)". In Questões fundamentais de sociologia - Indivíduo e sociedade. Rio de Janeiro: Jorge Zahar Editor, p. 5982.

SCHIMDT, M. L. S. \& MAHFOUD, M.. "Halbwachs: Memória coletiva e experiência". Revista do Instituto de Psicologia. São Paulo: USP, 1993, v. 4, 1 e 2, p. 285-298.

STERNHEIM, Alfredo. Cinema da Boca. Dicionário de diretores. São Paulo: Imprensa Oficial do Estado de São Paulo, 2005.

SUZUKI, Teiiti. "Mobilidade geográfica de imigrantes japoneses". In: SATO, Hiroshi; MAEYAMA, Takashi. Assimilação e integração dos japoneses no Brasil. São Paulo: Edusp, 1973.

TRUNK, Matheus. "Entrevista com Alfredo Sternheim, Astolfo Araújo e Edu Janks". In: Dossiê Rubem Biáfora: o crítico libertário [edição 10/07/2007]. São Paulo: Zingu!, 2007. [http://revistazingu.blogspot.com/2007/07/edicao-10.html]

TURNER, Victor. "Liminaridade e communitas". In: O processo ritual. Rio de Janeiro: Editora Vozes, [1969] 1974, p. 116-159.

. "Dewey, Dilthey, and Drama: um ensaio em Antropologia da Experiencia”. In:

Cadernos de Campo. São Paulo, USP-FFLCH, 2005, 13, p. 177-185.

. "Liminal to Liminoid, in Play, Flow, and Ritual. An Essay in Comparative Symbology" In: From Ritual to Theatre: The Human Seriousness of Play. New York: PAJ Publications, 1982, p. 20-60.

VIEIRA, João Luiz. "Distância/proximidade: o estilo Mizoguchi”. In: TAKAHASHI, Jo (cord). Mestre Mizoguchi. Seleção dos mais belos filmes. São Paulo: Fundação Japão/Cinemateca Brasileira, 1990.

WILLEMS, Emílio. Aspectos da aculturação dos japoneses no Estado de São Paulo. São Paulo: Universidade de São Paulo - Faculdade de Filosofia, Ciências e Letras, 1948.

WILLER, Claudio. "Os samurais do cinema japonês: outro mundo, outros tempos". Reserva Cultural. São Paulo: Lazuli Editora, 2007, dezembro, p. 74 - 74. 


\section{Crédito das imagens}

Figuras 1 e 2: Museu Histórico da Imigração Japonesa no Brasil

Figura 5: Família Tanaka

Figuras 4, 6, 7, 10, 13, 14 e 15: Sociedade Brasileira de Cultura Japonesa. Coronia Gueinoshi (História da Arte da Colônia). São Paulo: Sociedade Brasileira de Cultura Japonesa, 1986.

Figuras 3 e 33: IGEPAC. Liberdade: inventário geral do patrimônio ambiental, cultural e urbano de São Paulo. São Paulo: SMC/DPH, 1987. Cadernos do IGEPAC-SP 2.

Figuras 8 e 9: Alfredo Sternheim

Figuras 11 e 12: Marina Narahara

Figura 16: SIMÕES, Inimá Ferreira. Salas de cinema de São Paulo. São Paulo: PW/Secretaria Municipal de Cultura, 1990.

Figuras 17 e 19: Aiso Ban Misora Hibari. Tóquio: Asahi Shimbun Sha, 1989.

Figura 18: http://tokyo5.wordpress.com/2008/12/22/

Figura 20 e 29: CALIL, Carlos Augusto. Japão - Cinema \& Literatura. São Paulo: Fundação Japão/Cinemateca Brasileira, 1991.

Figuras 21, 24 e 25: TESSIER, Max. Images du cinema japonais. Paris : H. Veyrier, 1981.

Figura 22:

http://commons.wikimedia.org/wiki/File:Kinuyo_Tanaka_in_Jinsei_no_onimotsu_1935.jpg

Figura 23 e 27: TASSONE, Aldo. Akira Kurosawa. Paris: Flammarion, 1990.

Figura 28: TAKAHASHI, Jo (cord). Mestre Mizoguchi. Seleção dos mais belos filmes. São

Paulo: Fundação Japão/Cinemateca Brasileira, 1990.

Figura 30: SILVER, Alain. The Samurai Film. Woodstock: Overlook Press, 1983.

Figura 31: http://www.arts-wallpapers.com/movie_wallpapers/harakiri/index.htm

Figura 32: KAWAKITA, Kashiko, RICHIE, Donald e SATO, Tadao. Japão, a história através do cinema. Lisboa: Cinemateca Portuguesa, 1982. 